INEL-95/0054

\title{
Advanced Mixed Waste Treatment Project Melter System Preliminary Design Technical Review Meeting
}

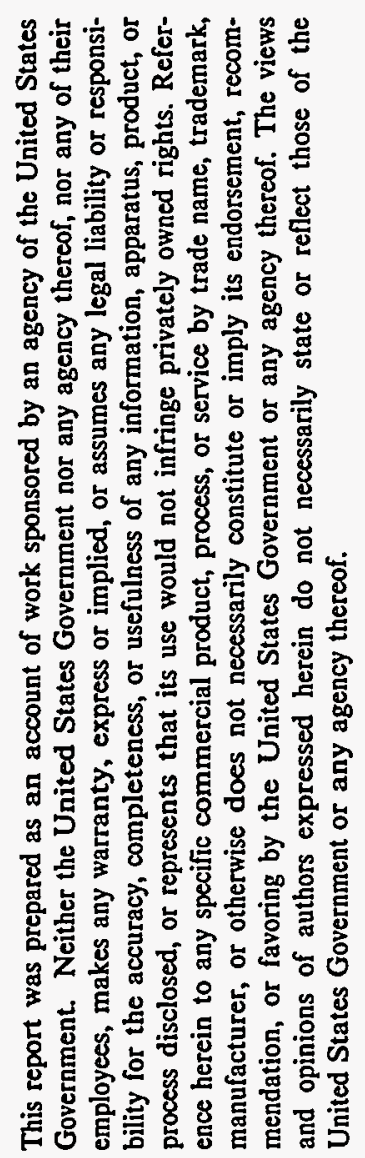

T. L. Eddy

B. D. Raivo

N. R. Soelberg

O. Wiersholm

Published February 1995

Idaho National Engineering Laboratory

Lockheed Idaho Technologies Company

Idaho Falls, Idaho 83415

Prepared for the

U.S. Department of Energy

Idaho Operations Office

Under DOE Idaho Operations Office

Contract DE-AC07-94ID13223

HH

DISTRIEUTION OF THIS DOCLMENTI IS UNLIMITED 
93T 


\section{DISCLAIMER}

Portions of this document may be illegible in electronic image products. Images are produced from the best available original document. 


\begin{abstract}
The Idaho National Engineering Laboratory Advanced Mixed Waste Treatment Project sponsored a plasma arc melter technical design review meeting to evaluate high-temperature melter system configurations for processing heterogeneous alpha-contaminated low-level radioactive waste (ALLW). Thermal processing experts representing Department of Energy contractors, the Environmental Protection Agency, and private sector companies participated in the review. The participants discussed issues and evaluated alternative configurations for three areas of the melter system design: plasma torch melters and graphite arc melters, offgas treatment options, and overall system configuration considerations. The Technical Advisory Committee for the review concluded that graphite arc melters are preferred over plasma torch melters for processing ALLW. Initiating involvement of stakeholders was considered essential at this stage of the design. For the offgas treatment system, the advisory committee raised the question whether to a use wet-dry or a dry-wet system. The committee recommended that the waste stream characterization, feed preparation, and the control system are essential design tasks for the high-temperature melter treatment system. The participants strongly recommended that a complete melter treatment system be assembled to conduct tests with nonradioactive surrogate waste material. A nonradioactive test bed would allow for inexpensive design and operational changes prior to assembling a system for radioactive waste treatment operations.
\end{abstract}




\section{SUMMARY}

The Advanced Mixed Waste Treatment Project (AdvMWTP) invited thermal processing and offgas treatment experts representing many DOE projects, consultants, and engineering firms in the United States and Europe to participate in a melter system preliminary design technical review meeting in October 1994. DOE is supporting a wide variety of programs to develop processes for mixed and radioactive waste. The results of this meeting are valuable in assessing technologies for this DOE project.

The purpose for the meeting was two-fold:

1. Conduct an objective evaluation of thermal treatment processing options for alphacontaminated mixed low-level radioactive waste

\section{Obtain feedback on INEL's thermal treatment process preliminary design.}

INEL engineers presented their evaluations and preliminary designs for three thermal treatment processing topics: plasma torch melters and arc melters, offgas treatment options, and overall system configuration and issues. A Technical Advisory Committee comprised of a diverse group of thermal processing and offgas treatment experts participated in the meeting to make comments, promote discussion, and provide objectivity. The committee members were divided into subcommittees representing the three topics of design presented at the meeting. All personnel attending were encouraged to ask questions, engage in discussion, and comment on the presentations.

This report is formatted so that the meeting background and introduction is covered in Section 1. Sections 2 through 7 include the materials presented by the INEL AdvMWTP personnel. Discussions, results, conclusions and recommendations are presented in Section 8.

A brief background on radioactive waste descriptions, classifications, current inventories and potential disposal options was presented. Various strategies for degree and method of treatment and ultimate disposal of stored and buried alpha-contaminated low-level radioactive waste (ALLW) are being considered at the INEL. No final decisions have been made.

An overview of commercial and industrial thermal treatment system applications was presented, which included advantages and disadvantages for multiple categories. Thermal treatment has been applied successfully to a wide range of industrial and hazardous waste streams. Volume and disposal cost reduction and stabilization of the hazardous constituents into a glassceramic matrix are the main advantages of high-temperature treatment systems.

The ALLW stored at the INEL has been categorized into five major waste streams. INEL engineers and scientists have developed a robust process and a stable glass-ceramic waste form called iron enriched basalt (IEB). IEB is formed in a high-temperature melter by adding 0 to $40 \mathrm{wt} \%$ soil to the heterogeneous waste feed stream. The makeup of the ALLW streams and the advantages of IEB were presented. 
Results and conclusions of past system studies were presented, as were criteria and requirements for final waste. The ability to treat heterogeneous waste streams using one process into a robust waste form was preferred. Melter system configurations, operation, and control alternatives were discussed.

Primary results, conclusions, and recommendations are as follows:

- The systems approach to the thermal treatment system, including waste pretreatment, treatment, offgas control, and secondary waste streams was applauded. At this stage, the initial site, waste characterization, waste retrieval, and containment issues were not included.

- The advisory committee strongly recommended that now is the time to proactively pursue stakeholder involvement. The stakeholders include the local and state governments, regulatory agencies, and local population.

- Graphite electrode arc melters were preferred over plasma torch systems for processing of the heterogeneous mixed wastes streams such as the ALLW.

- There was much discussion over whether to use a wet-dry or a dry-wet air pollution control system. The dry-wet system was proposed on the basis of its ability to meet a preliminary list of offgas treatment objectives; the wet-dry offgas system may be preferred because of increasingly strict regulatory limits on dioxin emission. The wet-dry system is less prone to small amounts of dioxin generation owing to the faster and lower temperature quench downstream of the afterburner. The dry-wet system uses a baghouse and a wet scrubber to separately remove one secondary waste stream of particulate, radionuclides, and toxic metals, and another aqueous secondary waste stream containing dissolved chlorides, sulfates, and much smaller amounts of particulate, toxic metals, and radionuclides. The wet-dry system uses a free-jet scrubber and mist eliminator system to scrub particulate, toxic metals, radionuclides, and acid gases, and produces a single aqueous mixed waste secondary stream. Generation of a single secondary mixed waste stream may be advantageous in some scenarios, whereas generating separate dry particulate and aqueous scrubber secondary streams may be better in other scenarios. A final determination of the wet-dry and dry-wet question depends on verifying the performance of each system with offgas from these types of wastes, more specific functional and operating requirements, safety analysis reports, and secondary waste treatment goals.

- Waste stream characterization, feed preparation, and the control system will be essential design tasks for the high-temperature melter treatment system. The design should include mass and energy balances to ensure full evaluation of all steps in the process. All phases of the waste treatment and disposal process will impact the design and operation of other phases.

- The Technical Advisory Committee strongly recommended near-full-scale testing of a complete melter treatment system to conduct tests with nonradioactive surrogate waste material. The nonradioactive test bed would allow for less costly design and 
operational changes prior to assembling a system for radioactive waste treatment operations. The test bed should be designed and operated based on the results of the systems design and meet the expected waste treatment requirements. Results of the nonradioactive testing will provide design and operating data for the radioactive treatment system.

The main advantage and strength of the technical review meeting was its format. A wide variety of technical experts attended the meeting, representing DOE contractors, consultants, and private sector engineering firms. They represented competing programs, melter system vendors, and thermal processing personnel. 
(20. 


\section{ACKNOWLEDGEMENTS}

This work was supported through the Advanced Mixed Waste Treatment Project of the Waste Management Operations Directorate under the direction of project manager $\mathrm{N}$. K. Rogers. Technical consultation by A. Chambers, L. W. Fish, L. G. Gale, B. Marshall, B. Trimberger, and K. Quapp is greatly appreciated. Review meeting preparation and facilitation by J. L. Ulrich, A. M. Conner, P. M. Hanny, L. C. Seward, and T. A. Ward was absolutely essential and is appreciated. Assistance in the preparation of the manuscript by D. R. Pack is also appreciated.

Special acknowledgement must be given to R. C. Eschenbach, representing Retech, Inc, and P. Cowx, representing ELKEM. They were not able to participate on the Technical Advisory Committee owing to a potential for conflict of interest. However, Eschenbach and Cowx both contributed valuable information during the general discussions. 


\section{LIST OF ATTENDEES}

October 24-25, 1994

Gary Anderson

Lockheed Idaho Technologies Company

P.O. Box 1625

Idaho Falls, ID 83415-2414

(208) $526-4669$

Steven Bates

Lockheed Idaho Technologies Company

P.O. Box 1625

Idaho Falls, ID 83415-3710

(208) $526-6790$

Fax (208) 526-6802

Curtis Branter

Lockheed Idaho Technologies Company

P.O. Box 1625

Idaho Falls, ID 83415-8108

(208) 526-6854

Fax (208) 526-8405

Dick Callow

Lockheed Idaho Technologies Company

P.O. Box 1625

Idaho Falls, ID 83415-3710

(208) 526-2042

Fax (208) 526-6802

Steve Cavin

Westinghouse Savannah River Corp.

WSCR, SRTC, 773-A/C-133

Aiken, SC 29804

(803) $725-5270$

Fax (803) 725-4704
Michael Arndt

Lockheed Env. Systems \& Tech. Co.

1920 E. 17th Street

Idaho Falls, ID 83404

(208) 524-7322

Fax (208) 524-9036

Bob Benedict

Argonne National Laboratory

P.O. Box 2528, MS 6000

Idaho Falls, ID 83403

(208) 533-7166

Fax (208) 533-7735

Dan Burns

Westinghouse Savannah River Co.

Bldg. 676-IT

Aiken, SC 29802

(803) 557-1166

Fax (803) 557-1176

Kevin P. Carney

Argonne-West

P.O. Box 2528, MS 6000

Idaho Falls, ID 83403

(208) 533-7263

Fax (208) 533-7755

Andrea Chambers

Lockheed Idaho Technologies Company

P.O. Box 1625

Idaho Falls, ID 83415

(208) 526-9008

Fax (208) 526-4017 
Dave L. Cheek

Director, Technology Development Plasma Energy Corp.

7516 Precision Drive

Raleigh, NC 27613

(919) 598-3333

Fax (919) 598-3350

Dr. Peter Cowx

Elken Technologies a/s

Nydalsvn, 26 B

P.O. Box 4376 Torshov

N-0402 Oslo - Norway

Phone - 011-47-22-45-06-00 or 15

Fax - 011-47-22-45-06-10

Dr. S. V. Dighe

Westinghouse Electric Corporation

Science \& Tech. Center

1310 Beulah Road

Pittsburgh, PA 15235

(412) $256-2235$

Fax (412) 256-1222

Dr. Richard C. Eschenbach

Retech, Inc.

P.O. Box 997

Ukiah, CA 95482

(707) $462-6522$

Fax (707) 462-4103

Dr. Jerry Feinman

J. Feinman \& Associates, Inc.

6083 Greenspointe Dr.

Boynton Beach, FL 33437

(407) 731-2580

Fax (407) 731-2582
Jim Connell

Thermo Technology Ventures

P.O. Box 1625

Idaho Falls, ID 83415-1631

(208) 526-0229

Fax (208) $526-4560$

Howard F. Davis, Jr.

327 Sandalwood Court

Carnegie, PA 15106-1544

(412) 429-0367

Fax (412) 923-2019

Tom Eddy

Lockheed Idaho Technologies Company

P.O. Box 1625

Idaho Falls, ID 83415-2210

(208) $526-8750$

Fax (208) $526-0690$

Lawrence C. Farrar

WDTI

P.O. Box 4182

Butte, MT 59702

(406) 494-5555

Fax (406) 494-7766

Fred Feizollahi

Environmental Services Division

Morrison Knudsen Corporation

180 Howard Street

San Francisco, CA 94105

(415) $442-7546$

Fax (415) 442-7673 
Larry Fish

Lockheed Idaho Technologies Company

P.O. Box 1625

Idaho Falls, ID 83415-3765

(208) $526-1794$

Fax (208) 526-8939

James Frost

Simplot Decision Support Center

P.O. Box 8020

Pocatello, ID 83209

(208) 236-4549

Fax (208) 236-4367

Ray Geimer

SAIC

545 Shoup Ave.

Idaho Falls, ID 83402

(208) 528-2144

Fax (208) 528-2194

Alan Hare

30 Easson Road, Redcar

Cleveland IS10 IHJ, England

Phone - 011-44-642-482-681

Fax - 011-44-642-482-681

James Jones

U.S. Department of Energy

Idaho Operations Office

785 DOE Place, MS 1145

Idaho Falls, ID 83401-1562

(208) 526-0237

Fax (208) 526-0553
Bruce Forsberg

Plasma Energy Applied Tech., Inc.

4914 Morres Mill Road

Huntsville, AL 35811

(205) 859-3006

Fax (205) 859-9588

Leland Gale

Lockheed Idaho Technologies Company

P.O. Box 1625

Idaho Falls, ID 83415

(208) $526-0180$

Fax (208) 526-9555

Bob Gillins

SAIC

545 Shoup Ave.

Idaho Falls, ID 83401

(208) 528-2114

Fax (208) 528-2194

Karl Hugo

U.S. Department of Energy

Idaho Operations Office

785 DOE Place

Idaho Falls, ID 83401

(208) 526-5375

Fax (208) 526-1184

Dr. John Koltz

U.S. Department of Energy

Idaho Operations Office

850 Energy Drive

Idaho Falls, ID 83401-1563

(208) 526-9909

Fax (208) 526-0160 
Herb LaFond

Simplot Decision Center

P.O. Box 8020

Pocatello, ID 83209

(208) 236-3040

Fax (208) 236-4367

C. C. Lee

U.S. Environmental Protection Agency

26 West Martin Luther King Dr., MS 481

Cincinnati, $\mathrm{OH} 45268$

(513) 569-7520

Fax (513) 569-7276

Jerry L. May

Lockheed Idaho Technologies Company

P.O. Box 1625

Idaho Falls, ID 83415-5217

(208) 526-6674

Fax (208) 526-3499

Ron Mizia

Lockheed Idaho Technologies Company

P.O. Box 1625

Idaho Falls, ID 83415

(208) 526-3352

Fax (208) 526-6517

Bill O'Connor

U.S. Bureau of Mines

1450 Queen Ave. SW

Albany, OR 97321

(503) $967-5834$

Fax (503) 967-5958

Tom O'Halleran

Lockheed Idaho Technologies Company

P.O. Box 1625

Idaho Falls, ID 83415

(208) 526-3557

Fax (208) 526-3499
Jerry Langford

Lockheed Idaho Technologies Company

P.O. Box 1625

Idaho Falls, ID 83415

(208) 526-1417

Fax (208) 526-9555

Guy Loomis

Lockheed Idaho Technologies Company

P.O. Box 1625

Idaho Falls, ID 83415-3710

(208) 526-9208

Fax (208) 526-6802

John McFee

IT Corporation

5301 Central Avenue NE, Suite 700

Albuquerque, NM 87108

(505) 262-8800

Fax (505) 262-8855

Lee Nelson

Lockheed Idaho Technologies Company

P.O. Box 1625

Idaho Falls, ID 83415-5213

(208) $526-3093$

Fax (208) 526-3499

Michael O'Dell

Lockheed Environ. Systems \& Tech.

1920 E. 17th St.

Idaho Falls, ID 83404

(208) 524-7322

Fax (208) 524-9036

Colleen Owens

SEG

1470 N. Skyline

Idaho Falls, ID 83402

(208) 528-6658

Fax (208) 528-7819 
Doug Parker

Lockheed Idaho Technologies Company

P.O. Box 1625

Idaho Falls, ID 83415

(208) 526-4857

Fax (208) 526-9555

Kevin Price

U.S. DOE

Idaho Operations Office

785 DOE Place

Idaho Falls, ID 83401

(208) 526-5192

Fax (208) 526-6249

N. Kim Rogers

Lockheed Idaho Technologies Company

P.O. Box 1625

Idaho Falls, ID 83415-2424

(208) 526-7775

Fax (208) 526-9555

Dr. Randy Seeker

EER Corporation

18 Mason

Irvine, CA 92718

(714) 859-8851

Fax (714) 859-3194

Nick Soelberg

Lockheed Idaho Technologies Company

P.O. Box 1625

Idaho Falls, ID 83415-3625

(208) 526-6923

Fax (208) 526-4017
David Pitts

Focus Environmental

9050 Executive Park Dr.

Suite A-202

Knoxville, TN 37923

(615) 694-7517

Fax (615) 531-8854

Brian Raivo

Lockheed Idaho Technologies Company

P.O. Box 1625

Idaho Falls, ID 83415-3765

(208) 526-8497

Fax (208) 526-8939

Jeff Ruffner

Mountain States Energy, Inc.

P.O. Box 4078

Butte, MT 59701

(406) $494-7100$

Fax (406) 494-7230

Mr. H. W. Shaffer

Westinghouse Electric Corporation

Science \& Tech Center

1310 Beulah Road

Pittsburgh, PA 15235

(412) 256-2235

Fax (412) 256-1222

Ben Teheranian

Environmental Services Division

Morrison Knudsen Corporation

180 Howard Street

San Francisco, CA 94105

(415) $442-7546$

Fax (415) 442-7673 
Dr. Krishna Vinjamuri

Lockheed Idaho Technologies Company

P.O. Box 1625

Idaho Falls, ID 83415-5213

(208) 526-9277

Fax (208) 526-3449

Otto Wiersholm

Lockheed Idaho Technologies Company

P.O. Box 1625

Idaho Falls, ID 83415-3640

(208) 526-6677

Fax (208) 526-2641

Dr. J. Kenneth Wittle

Electro-Pyrolysis, Inc.

996 Old Eagle School Road, \#1118

Wayne, PA 19087

(610) 687-9070

Fax (610) 964-8570
Dr. Larry Waterland

Acurex Corp.

555 Clyde Avenue

Mountain View, CA 94043

(415) 254-2440

Fax (415) 254-2497

Philip Winston

Thermo Technology Ventures

P.O. Box 1625

Idaho Falls, ID 83415-1631

(208) 526-3679

Fax (208) 526-4560

Cooper Wright

PEAT/VRI

10306 Eaton Place, Suite 450

Fairfax, VA 22030

(703) $934-6300$

Fax (703) 273-9398 


\section{TECHNICAL ADVISORY COMMITTEE}

\section{Organizing Committee}

N. Kim Rogers

Otto Wiersholm

Gary L. Anderson

Dr. Thomas L. Eddy

Dr. Peter C. Kong

Brian Raivo

Dr. Jim Sears

Nick Soelberg

Jan Ulrich

Terry Ward

Integrated Melter System Subcommittee

Dr. John Kolts, Chair

Fred Feizollahi, Co-Chair

C. C. Lee

Ben Teheranian

Melter Design Subcommittee

Alan Hare, Chair

Howard F. Davis Jr., Co-Chair

Dr. Jerry Feinman

Offgas Design Subcommittee

John McFee, Chair

Dr. Larry Waterman, Co-Chair

Dr. Randy Seeker

Dan Burns

Heather Holmes-Burns

Dave Pitts 


\section{CONTENTS}

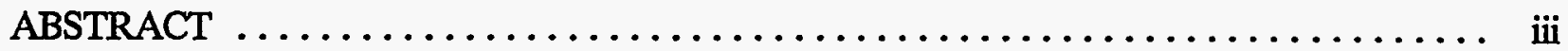

SUMMARY $\ldots \ldots \ldots \ldots \ldots \ldots \ldots \ldots \ldots \ldots \ldots \ldots \ldots \ldots \ldots \ldots \ldots \ldots$

ACKNOWLEDGEMENTS $\ldots \ldots \ldots \ldots \ldots \ldots \ldots \ldots \ldots \ldots \ldots \ldots \ldots \ldots \ldots \ldots$

LIST OF ATTENDEES $\ldots \ldots \ldots \ldots \ldots \ldots \ldots \ldots \ldots \ldots \ldots \ldots \ldots \ldots \ldots$

TECHNICAL ADVISORY COMMITTEE $\ldots \ldots \ldots \ldots \ldots \ldots \ldots \ldots \ldots \ldots \ldots \ldots$ xvii

ACRONYMS $\ldots \ldots \ldots \ldots \ldots \ldots \ldots \ldots \ldots \ldots \ldots \ldots \ldots \ldots \ldots \ldots \ldots \ldots \ldots \ldots$

1. THE ADVANCED MIXED WASTE TREATMENT PROJECT . . . . . . . . 1-1

1.1 Related Programs with Similar Objectives $\ldots \ldots \ldots \ldots \ldots \ldots \ldots \ldots \ldots$

1.2 Melter System Preliminary Design Technical Review Meeting . . . . . . . 1-2

2. SUMMARY OF INEL MIXED WASTE AND TREATMENT SYSTEM

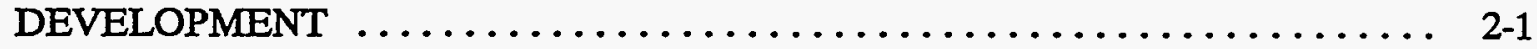

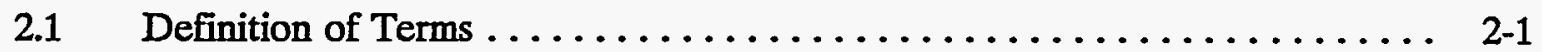

$2.2 \quad$ Waste Types and Present Disposal Guidance $\ldots \ldots \ldots \ldots \ldots \ldots \ldots \ldots$

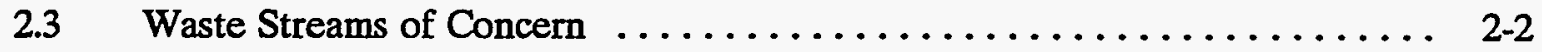

$2.4 \quad$ The Problem $\ldots \ldots \ldots \ldots \ldots \ldots \ldots \ldots \ldots \ldots \ldots \ldots \ldots \ldots \ldots \ldots \ldots$

2.5 Strategies for Solution $\ldots \ldots \ldots \ldots \ldots \ldots \ldots \ldots \ldots \ldots \ldots \ldots \ldots \ldots \ldots$

3. VITRIFICATION OF COMMERCIAL AND INDUSTRIAL WASTES $\ldots \ldots \ldots$

$3.1 \quad$ Commercial Applications $\ldots \ldots \ldots \ldots \ldots \ldots \ldots \ldots \ldots \ldots \ldots \ldots \ldots \ldots \ldots \ldots$

3.2 Industrial Applications $\ldots \ldots \ldots \ldots \ldots \ldots \ldots \ldots \ldots \ldots \ldots \ldots \ldots \ldots$

3.3 Radioactive Waste Applications $\ldots \ldots \ldots \ldots \ldots \ldots \ldots \ldots \ldots \ldots \ldots$

3.4 Military Waste Applications $\ldots \ldots \ldots \ldots \ldots \ldots \ldots \ldots \ldots \ldots \ldots \ldots \ldots$

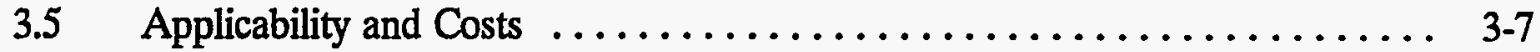

3.6 Electric Arc Melter Dust Treatment $\ldots \ldots \ldots \ldots \ldots \ldots \ldots \ldots \ldots \ldots$ 
4. WASTE STREAMS, SLAG CHARACTERISTICS, AND FINAL WASTE FORMS

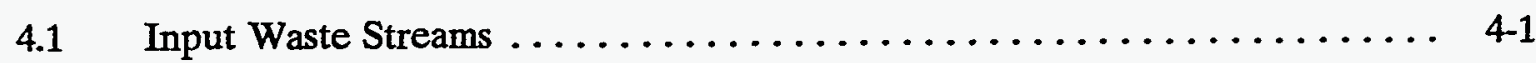

4.2 Slag Melt Compositions and Properties $\ldots \ldots \ldots \ldots \ldots \ldots \ldots \ldots \ldots$ 4-1

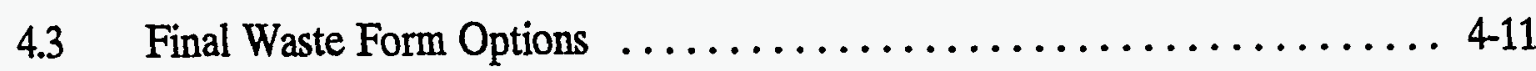

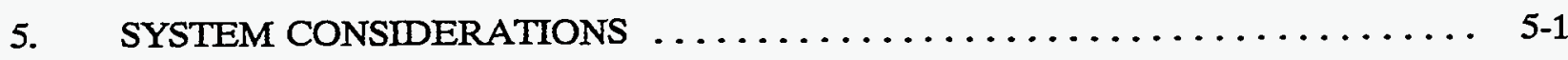

5.1 General Background from 1991-92 Studies on Buried Waste ......... 5-1

5.2 Criteria and Requirements for the Final Waste Form $\ldots \ldots \ldots \ldots \ldots \ldots$

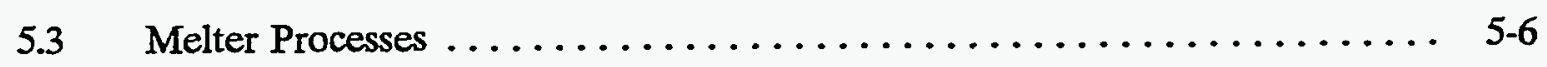

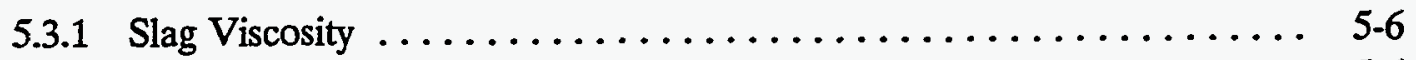

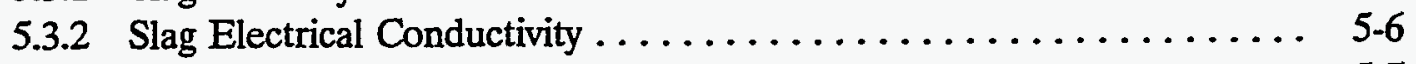

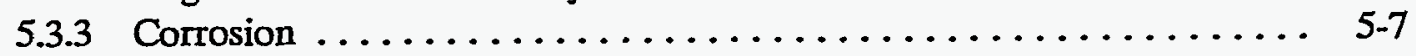

5.3.4 Slag Chemistry and Retention of TRU Nuclides ........... 5-7

5.3.5 Slag Chemistry and Control of HVPM $\ldots \ldots \ldots \ldots \ldots \ldots \ldots \ldots$ 5-8

5.3.6 Vitrification/Devitrification Processes $\ldots \ldots \ldots \ldots \ldots \ldots \ldots \ldots$ 5-8

$5.4 \quad$ Melter-Based Thermal Treatment Systems Background $\ldots \ldots \ldots \ldots \ldots \ldots$ 5.9

5.5 Review Meeting Considerations for a Melter-Based

Thermal Treatment System $\ldots \ldots \ldots \ldots \ldots \ldots \ldots \ldots \ldots \ldots \ldots . \ldots \ldots$

5.5.1 Review Meeting Focus .................... 5-15

5.5.2 Melter-Based System Conceptual Requirements ............ 5-17

5.5.3 Melter-Based System General Design Requirements .......... 5-18

5.6 Melter Based Thermal Treatment System Scenarios ............. 5-19

6. INCINERATOR AND MELTER DESIGN CONSIDERATIONS $\ldots \ldots \ldots \ldots .6-1$

6.1 Melter Geometrical Considerations .................. 6-1

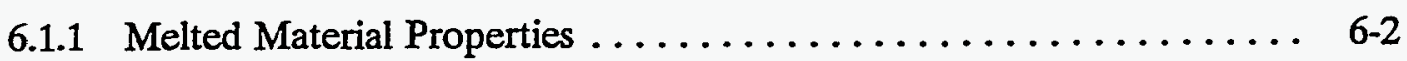

6.1.2 Mixing and Stirring Effects in the Slag $\ldots \ldots \ldots \ldots \ldots \ldots \ldots, 6-3$

6.1.3 Geometrical Example ..................... 6-6

6.1.4 Effect of Radiation: Long Arc Versus Short Arc ............ 6-6

6.2 Summary of Advantages and Disadvantages $\ldots \ldots \ldots \ldots \ldots \ldots \ldots \ldots, 6 \ldots \ldots$

6.2.1 Melter Options Considered Individually $\ldots \ldots \ldots \ldots \ldots \ldots \ldots .6-11$ 


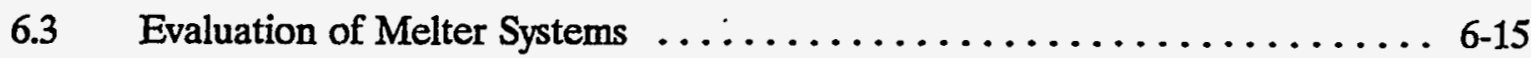

6.3.1 Weighting Melter Options and Features $\ldots \ldots \ldots \ldots \ldots \ldots \ldots, 6-15$

6.3.2 Melter System Evaluation Results ................... 6-16

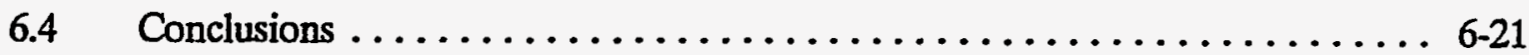

7. OFFGAS SYSTEM DESIGN CONSIDERATIONS $\ldots \ldots \ldots \ldots \ldots \ldots \ldots \ldots$ 7-1

7.1 Design Offgas Composition and Flowrate Requirements $\ldots \ldots \ldots \ldots \ldots$ 7-1

7.2 Overview of a Preliminary Design that Meets the Requirements $\ldots \ldots \ldots$ 7-3

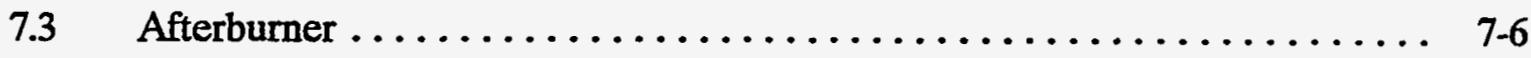

$7.4 \quad$ Partial Temperature Quench $\ldots \ldots \ldots \ldots \ldots \ldots \ldots \ldots \ldots \ldots \ldots \ldots \ldots \ldots \ldots \ldots$

7.5 Particulate and Radionuclide Control $\ldots \ldots \ldots \ldots \ldots \ldots \ldots \ldots \ldots \ldots$

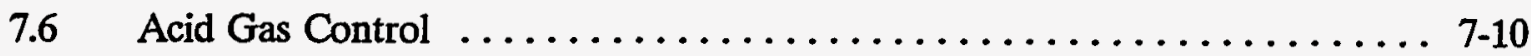

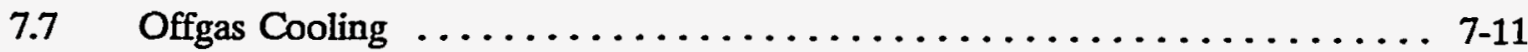

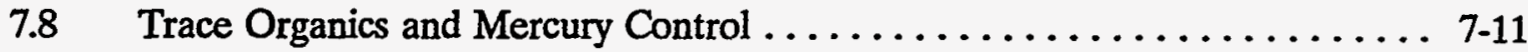

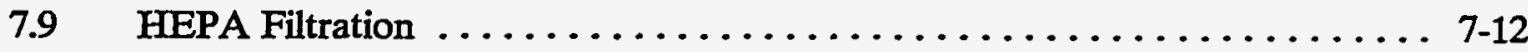

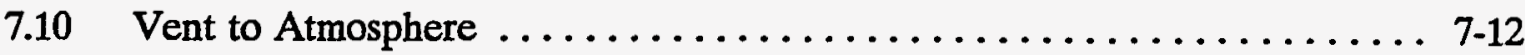

8. CONCLUSIONS AND RECOMMENDATIONS $\ldots \ldots \ldots \ldots \ldots \ldots \ldots \ldots$. 8 -1

$8.1 \quad$ Introduction $\ldots \ldots \ldots \ldots \ldots \ldots \ldots \ldots \ldots \ldots \ldots \ldots \ldots \ldots, 8,1$

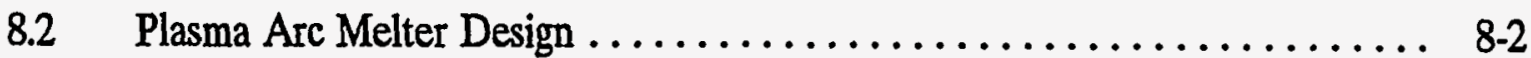

$8.3 \quad$ Offgas System Design $\ldots \ldots \ldots \ldots \ldots \ldots \ldots \ldots \ldots \ldots \ldots \ldots \ldots \ldots \ldots \ldots$

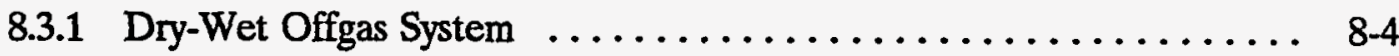

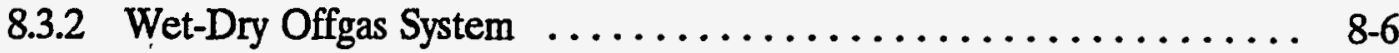

8.3.3 Comparison of Dry-Wet and Wet-Dry Offgas Systems ......... 8.6

8.3.4 Miscellaneous Comments $\ldots \ldots \ldots \ldots \ldots \ldots \ldots \ldots \ldots \ldots, 8.9 . \ldots$

8.3 .5 Conclusions $\ldots \ldots \ldots \ldots \ldots \ldots \ldots \ldots \ldots \ldots \ldots \ldots \ldots \ldots, 8,11$

8.3.6 Recommendations $\ldots \ldots \ldots \ldots \ldots \ldots \ldots \ldots \ldots \ldots \ldots . .6 .13$

$8.4 \quad$ Overall System Design $\ldots \ldots \ldots \ldots \ldots \ldots \ldots \ldots \ldots \ldots \ldots \ldots \ldots . . \ldots \ldots$

8.4.1 Stakeholder Involvement $\ldots \ldots \ldots \ldots \ldots \ldots \ldots \ldots \ldots \ldots . . .14$ 
8.4.2 Impact of the System Front End on Selection of a Melter . . . . . . . 8-14

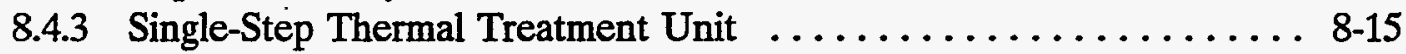

8.4.4 Operability and Maintainability Considerations ............ 8-16

8.4 .5 Material Handling $\ldots \ldots \ldots \ldots \ldots \ldots \ldots \ldots \ldots \ldots \ldots \ldots \ldots . \ldots \ldots \ldots$

8.4.6 System back-end considerations $\ldots \ldots \ldots \ldots \ldots \ldots \ldots \ldots \ldots$. $\ldots \ldots \ldots$

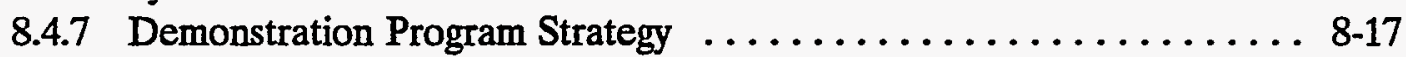

8.4.8 Input Waste Acceptance Criteria $\ldots \ldots \ldots \ldots \ldots \ldots \ldots \ldots$. . . . . . . . . . .

8.4 .9 Final Waste Form Criteria $\ldots \ldots \ldots \ldots \ldots \ldots \ldots \ldots \ldots$. . . . . . . . . . . . . .

8.4.10 On-line Continuous Emissions Monitors .............. 8-17

$8.5 \quad$ Recommendations $\ldots \ldots \ldots \ldots \ldots \ldots \ldots \ldots \ldots \ldots \ldots \ldots \ldots \ldots$

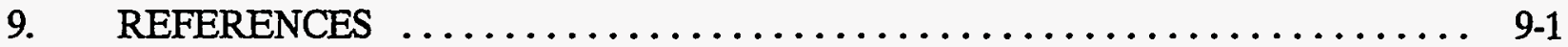

Appendix A-Integrated Melter System Subcommittee Report .............. A-1

Appendix B-Melter Design Subcommittee Report $\ldots \ldots \ldots \ldots \ldots \ldots \ldots \ldots \ldots \ldots \ldots$ B-1

Appendix C-Offgas Design Subcommittee Report . . . . . . . . . . . . . C-1

Appendix D-Offgas System Mass and Energy Balance Calculations . . . . . . . . . D-1

\section{FIGURES}

2-1. Aerial view of the INEL RWMC, TSA, and the SDA $\ldots \ldots \ldots \ldots \ldots \ldots$

2-2. TRU waste in retrievable storage $\ldots \ldots \ldots \ldots \ldots \ldots \ldots \ldots \ldots \ldots \ldots \ldots \ldots$

2-3. Present TSA stored waste inventory totals approximately $60,000 \mathrm{cu}$ meters

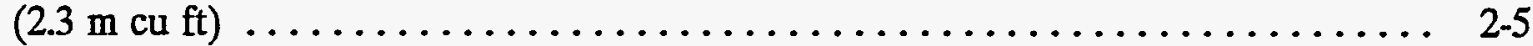

2-4. INEL stored waste drums containing clothing, plastic, metals, glass, and process

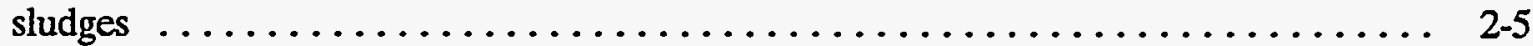

2-5. Fifty-eight percent of INEL stored waste is in bins and boxes $\ldots \ldots \ldots \ldots$

3-1. The USBM 3-phase ac arc melter system as used for the ASME tests ....... 3-2

3-2. The USBM ac arc melter system as modified for the INEL tests . . . . . . . . . 3-4

3-3. The INERTAM dc nontransferred torch system $\ldots \ldots \ldots \ldots \ldots \ldots \ldots \ldots$

3-4. Concept of the PEAT dc nontransferred plasma torch system $\ldots \ldots \ldots \ldots . \ldots$

3-5. The MSE/Retech de plasma centrifugal reactor system $\ldots \ldots \ldots \ldots \ldots \ldots \ldots$

3-6. The EPI/MIT Mark II DC graphite electrode and hearth arc melter $\ldots \ldots \ldots \ldots$ 3-10 
3-8. A conceptual comparison of current disposal costs with melting disposal costs for different final waste forms and their respective repositories.

3-9. The Elkem 3-phase ac arc melter HTMR system ................ 3-14

3-10. The Davy-McKee dc Hi-Plas EAF dust process flowsheet $\ldots \ldots \ldots \ldots \ldots \ldots$. . . . . .

3-11. The IMS-Tetronics dc torch/graphite plasma melter system $\ldots \ldots \ldots \ldots \ldots \ldots \ldots$

3-12. The Pyromet-Mintek dc plasma-arc melter $\ldots \ldots \ldots \ldots \ldots \ldots \ldots \ldots \ldots \ldots$

3-13. The Ticron extended plasma-arc reduction system $\ldots \ldots \ldots \ldots \ldots \ldots \ldots \ldots \ldots$

3-14. The Ausmelt Sirosmelt system with a fuel/air/oxygen lance ............ 3-18

4-1. Relative concentrations of the major waste streams in the TSA, SDA and Pit 9 of

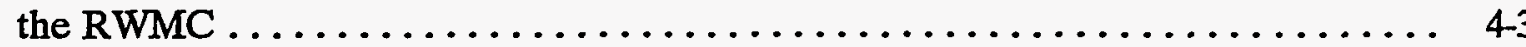

4-2. Plot of slag composition for the average TRUW (A-Series) waste as a function of the mass of soil in the mixture $\ldots \ldots \ldots \ldots \ldots \ldots \ldots \ldots \ldots \ldots \ldots \ldots \ldots . \ldots \ldots$

4-3. Plot of slag composition for the RFP 741 hydrated metal oxide (H1-Series) waste as a function of the mass of soil in the mixture $\ldots \ldots \ldots \ldots \ldots \ldots \ldots \ldots \ldots \ldots$

4-4. Plot of slag composition for the RFP 742 hydrated metal oxide (H2-Series) waste as a function of the mass of soil in the mixture $\ldots \ldots \ldots \ldots \ldots \ldots \ldots \ldots \ldots . \ldots . \ldots$

4-5. Plot of slag composition for the RFP 743 calcium-silicated (S-Series) waste and organic sludge as a function of the mass of soil in the mixture ............ 4-9

4-6. Plot of slag composition for the RFP 744 Portland-cemented organic sludge (P-Series) waste as a function of the mass of soil in the mixture $\ldots \ldots \ldots \ldots \ldots \ldots$

47. Plot of slag composition for the RFP 745 alkali-nitrate evaporator salt (N-Series) waste as a function of the mass of soil in the mixture $\ldots \ldots \ldots \ldots \ldots \ldots \ldots \ldots$ 4-10

4-8. Plot of slag composition for the nonspecial source metallic (M-Series) waste as a function of the mass of soil in the mixture $\ldots \ldots \ldots \ldots \ldots \ldots \ldots \ldots \ldots \ldots \ldots$

4-9. Molten basalt viscosity as a function of temperature for the A-Series compositions ............................... 4-12

4-10. Molten basalt electrical conductivity as a function of temperature for the A-Series compositions 
4-11. Specific heat capacity as a function of temperature for A-0 composition slag with $\mathrm{Al}_{2} \mathrm{O}_{3}$ used as a reference (Reimann et al. 1992) . . . . . . . . . . . . 4-14

4-12. History of glass and ceramic waste form development $\ldots \ldots \ldots \ldots \ldots \ldots \ldots$

5-1. A conceptual (not to scale) incineration and melting system with no sorting (other

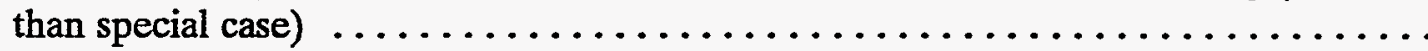

5-2. An approximate mass flow diagram of input waste streams and output waste forms based on estimated values $\ldots \ldots \ldots \ldots \ldots \ldots \ldots \ldots \ldots \ldots \ldots \ldots \ldots \ldots$

5-3. Illustration of the effect of adding flux to the slag melt $\ldots \ldots \ldots \ldots \ldots \ldots \ldots \ldots$

5-4. Preliminary process flow diagram of material categories within waste streams to indicate the probable types of processing needed $\ldots \ldots \ldots \ldots \ldots \ldots \ldots \ldots \ldots \ldots$-10

5-5. Conceptual sketch of electrically heated melters: (a) Joule-heated melter with the immersed electrodes in the horizontal configuration, (b) an arc-heated melter with 3-phase ac operation and graphite electrodes, and (c) a plasma-heated melter with 1-phase dc operation and both electrodes in the torch .................

5-6. The INEL Joule-heated melter with molybdenum electrodes used

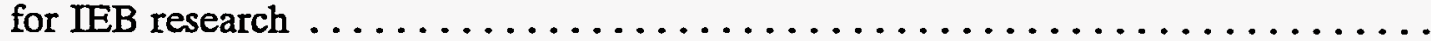

5-7. Plasma-heated melter torch-electrode configurations: (a) transferred-arc torch with the melt as the cathode and (b) nontransferred-arc torch with both electrodes in the

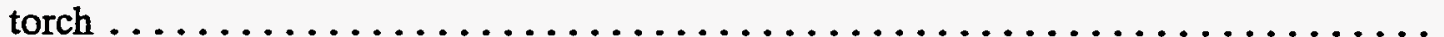

5-8. Plasma-heated melter used in the INEL PAFE experiment in the transferred-arc mode with 1-phase dc operation, metal electrode torch, an oxygen lance, and watercooled skull with a rotating chamber that is slowed to pour the slag $\ldots \ldots \ldots \ldots . . .5$

5-9. AdvMWTP melter and incinerator system flowsheet $\ldots \ldots \ldots \ldots \ldots \ldots \ldots \ldots \ldots$

5-10. AdvMWTP combined melter/incinerator system $\ldots \ldots \ldots \ldots \ldots \ldots \ldots \ldots \ldots \ldots$

5-11. AdvMWTP Offgas Treatment System $\ldots \ldots \ldots \ldots \ldots \ldots \ldots \ldots \ldots \ldots \ldots \ldots$

5-12. Thermal Treatment System radiological assay overview $\ldots \ldots \ldots \ldots \ldots \ldots \ldots \ldots$

6-1. Viscosities of common fluids and some selected waste slag compositions $\ldots \ldots \ldots$ 6-2

6-2. Electrical resistivities ( $\rho$ ) and conductivities ( $\sigma$ ) of common conductors and some selected waste slag compositions $\ldots \ldots \ldots \ldots \ldots \ldots \ldots \ldots \ldots \ldots \ldots$ 
6-3. Melter configurations considered: (1) dc with axial cathode and bottom anode, (b) dc transferred plasma torch with long arc, (c) dc with two parallel graphite electrodes, (d) 3-phase ac with three graphite electrodes, (e) dc with concentric graphite electrodes, (f) dc torch with rotating chamber $\ldots \ldots \ldots \ldots \ldots \ldots \ldots, 6-4$

6-4. The cylindrical-arc-to-circular-slag surface geometry for shape factor

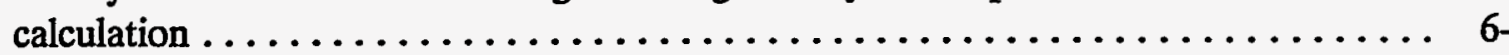

6-5. The variation of the shape factor between plasma arc and slag $\left(F_{a-s}\right)$ as a function of the ratio of arc length to melter radius $(\mathrm{L} / \mathrm{b}) \ldots \ldots \ldots \ldots \ldots \ldots \ldots, 6-10$

7-1. Offgas Treatment System $\ldots \ldots \ldots \ldots \ldots \ldots \ldots \ldots \ldots \ldots \ldots \ldots \ldots \ldots \ldots \ldots \ldots \ldots \ldots$

\section{TABLES}

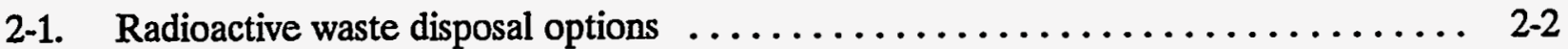

2-2. Waste streams of concern $\ldots \ldots \ldots \ldots \ldots \ldots \ldots \ldots \ldots \ldots \ldots \ldots \ldots \ldots \ldots \ldots \ldots \ldots \ldots \ldots, 2-4$

2-3. Melter system scoping studies $\ldots \ldots \ldots \ldots \ldots \ldots \ldots \ldots \ldots \ldots \ldots \ldots \ldots \ldots \ldots \ldots \ldots$

2-4. Melter system development and demonstration program $\ldots \ldots \ldots \ldots \ldots \ldots \ldots$ 2-8

3-1. Brief descriptions of the pilot-scale plasma/arc-heated melters being studied by DOE for the treatment of radioactive wastes $\ldots \ldots \ldots \ldots \ldots \ldots \ldots, 3-8$

3-2. Estimated cost savings on treatment options of SRS mixed LLW .......... 3-9

3-3. Existing EAF dust treatment technologies applicable to melting RWMC ALLW and TRUW materials

4-1. Mass and volumes per category in selected areas of the RWMC (Grandy, Eddy,

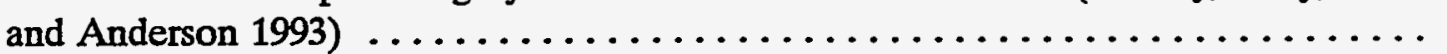

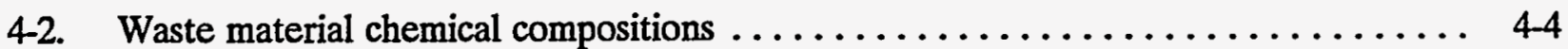

4-4. Input waste stream materials, potential treatment issues, and potential resolutions

4-5. Average slag composition from A waste plus soil $\ldots \ldots \ldots \ldots \ldots \ldots \ldots \ldots$

4-6. Final waste form options for different waste streams $\ldots \ldots \ldots \ldots \ldots \ldots \ldots \ldots$ 4-15

4-7. Selected properties for various waste forms $\ldots \ldots \ldots \ldots \ldots \ldots \ldots \ldots \ldots \ldots .17$

4-8. Comparison of high-temperature waste form properties $\ldots \ldots \ldots \ldots \ldots \ldots \ldots$ 4-18 
5-1. Processing options for using various Joule-heated and plasma-heated melters to make different viable waste forms $\ldots \ldots \ldots \ldots \ldots \ldots \ldots \ldots \ldots \ldots . . \ldots$

5-2. Thermal desorber/pyrolyzer oxidant $\ldots \ldots \ldots \ldots \ldots \ldots \ldots \ldots \ldots \ldots \ldots \ldots$

6-1. A summary of approximate melter geometrical relationships $\ldots \ldots \ldots \ldots \ldots \ldots$

6-2. Dimensions of melters for the configurations considered $\ldots \ldots \ldots \ldots \ldots \ldots \ldots$

6-3. Plasma arc and slag power input as a function of current and arc length for a 1-m

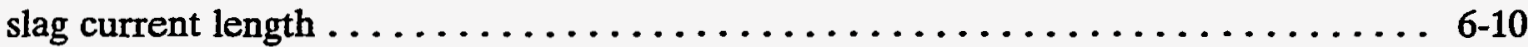

6-4. Relative advantages of various melter options $\ldots \ldots \ldots \ldots \ldots \ldots \ldots \ldots \ldots$

6-5. Summary of preliminary decisions on melter options $\ldots \ldots \ldots \ldots \ldots \ldots \ldots$

6-6. Summary of preliminary decisions on melter options in priority of

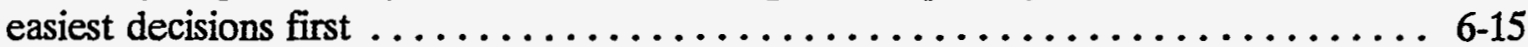

6-7. Option and feature weight rating scale $\ldots \ldots \ldots \ldots \ldots \ldots \ldots \ldots \ldots \ldots \ldots$

6-8. Weighting values for the melter options $\ldots \ldots \ldots \ldots \ldots \ldots \ldots \ldots \ldots \ldots \ldots$

6-9. Weighting values for the melter-option features $\ldots \ldots \ldots \ldots \ldots \ldots \ldots \ldots \ldots$

6-10. Qualitative ranking of melter systems with original options $\ldots \ldots \ldots \ldots \ldots \ldots$

6-11. Qualitative ranking of melter systems with improved options $\ldots \ldots \ldots \ldots \ldots \ldots$

6-12. Comparison of different melter system based on the different evaluation weighting systems $\ldots \ldots \ldots \ldots \ldots \ldots \ldots \ldots \ldots \ldots \ldots \ldots \ldots \ldots . \ldots \ldots \ldots$

7-1. Summary of predicted offgas flowrates and compositions $\ldots \ldots \ldots \ldots \ldots \ldots$

7-2. Potential emission limits for various pollutants $\ldots \ldots \ldots \ldots \ldots \ldots \ldots \ldots$

8-1. Comparison of dry-wet and wet-dry offgas systems $\ldots \ldots \ldots \ldots \ldots \ldots \ldots \ldots$ 


\section{ACRONYMS}

AdvMWTP Advanced Mixed Waste Treatment Project

ALLW alpha-contaminated low-level radioactive waste

BSG borosilicate glass

CERCLA Comprehensive Environmental Response, Compensations, and Liability Act

DOD Department of Defense

DOE Department of Energy

EAF electric arc furnace

EGR exhaust gas recirculation

EPA Environmental Protection Agency

EPI Electro-Pyrolysis Inc.

FFCA Federal Facilities Compliance Act

FWF final waste form

HLW high-level waste

HVPM high vapor pressure metal

IEB iron enriched basalt

IMPS - Incinerator-Melter Process Simulation

INEL Idaho National Engineering Laboratory

ITTS Integrated Thermal Treatment System Study

IWPF Idaho Waste Processing Facility

LDR land disposal restriction

LITCO Lockheed Idaho Technologies Company

LL low-level (waste)

LLW low-level waste 
MIT Massachusetts Institute of Technology

OTD Office of Technology Development

PCR plasma centrifugal reactor

RCRA Resource Conservation and Recovery Act

RWMC Radioactive Waste Management Complex

SDA Subsurface Disposal Area

TAC Technical Advisory Committee

TRU transuranic

TRUW transuranic waste

TSA Transuranic Storage Area

TSCA Toxic Substances Control Act

USBM U.S. Bureau of Mines

WAC Waste Acceptance Criteria

WIPP Waste Isolation Pilot Plant 


\section{Advanced Mixed Waste Treatment Project Melter System Preliminary Design Technical Review Meeting}

\section{THE ADVANCED MIXED WASTE TREATMENT PROJECT}

The Advanced Mixed Waste Treatment Project (AdvMWTP) is a programmatic waste management organization within Lockheed Idaho Technologies Company (LITCO), the Maintenance and Operations contractor for the Idaho National Engineering Laboratory (INEL). The AdvMWTP is funded under DOE EM-30 and evolved from the implementation strategy for the Idaho Waste Processing Facility (IWPF) activity. Separate parallel paths are being explored for the treatment of transuranic and alpha low-level waste: a private sector (non-DOE) treatment facility, versus the Idaho Waste Processing Facility (IWPF), a DOE line-item construction project. Decisions concerning the approach or combination of approaches for waste treatment will be made in FY 1997, or earlier, based on ongoing studies and the results of the Federal Facility Compliance Act Consent Order and discussions being conducted with the National Governors' Association. The IWPF or a private sector alternative is the facility designated under the FFCA Proposed Site Treatment Plan for treatment solutions for the mixed (radioactive and hazardous) waste stored in the Transuranic Storage Area (TSA) at the Radioactive Waste Management Complex (RWMC) at the INEL. The IWPF is the facility that would be constructed and operated under the DOE implementation strategy. DOE-ID also has a similar strategy for treatment solutions to encourage the private sector to provide treatment solutions for this waste. Three consortiums of private sector vendors have previously been tasked under DOE-ID contract to provide feasibility studies on how best to provide treatment solutions for this waste. IWPF and private sector activities parallel other DOE technology development and demonstration (EM-50) activities as does CERCLA (EM-40) activities in the thermal treatment area.

The IWPF project has been evaluating an arc melter thermal treatment process for treating alpha low-level mixed waste. The IWPF project has been using this process for a baseline to develop cost estimates and preconceptual designs. The final treatment process has not been selected. Selection will be made during or after the conceptual design phase of the project. The conceptual design for the IWPF is scheduled to begin in FY 1996.

\subsection{Related Programs with Similar Objectives}

Many DOE and DOD projects are developing and evaluating thermal treatment processes for a variety of waste streams, and they are considering various thermal treatment process configurations. Personnel within the AdvMWTP have collected and reviewed available information and evaluated various proposed thermal treatment processes to develop the most optimum treatment solution for these mixed wastes.

The DOE Office of Technology Development (OTD) in EM-50 is supporting an INEL/USBM arc melter demonstration at the U.S. Bureau of Mines in Albany, Oregon, and on a DC arc melter at Massachusetts Institute of Technology (MIT) with Electro-Pyrolysis Inc., and the Pacific Northwest Laboratory under the Buried Waste Integrated Demonstration program. 
The DOE OTD is also supporting demonstrations on the plasma hearth melter through Science Applications International and Retech under the Mixed Waste Integrated Program.

DOE Environmental Restoration, EM-40, is also supporting studies on mixed (radioactive and hazardous) waste at INEL's Pit 9 in the Radioactive Waste Management Complex as a demonstration of treating waste buried in pits and trenches. This demonstration includes use of the Retech plasma centrifugal reactor by Lockheed Environmental, Mountain States Energy, and Retech.

Prior to the conceptual design of the full line-item project, IWPF has been pursuing a melter demonstration. The objective of this melter demonstration is to prove melter technology for treating alpha low-level mixed waste. This includes a nonradioactive and a radioactive system demonstration. The activities leading to this demonstration include preliminary design engineering, final design engineering, construction, cold testing and hot testing. This demonstration test is scheduled to be accomplished by the end of FY 1997.

The major difference between the IWPF activity and the other DOE technology development melter programs is that the design of a complete facility and melter system is being considered, rather than emphasizing or developing a particular component. The IWPF plans include preliminary design, final design, and construction of a field/pilot-scale melter system for cold testing, then reusing it or a new nearly identical melter system for hot testing, and for testing the major input waste stream extremes. The major waste extremes include glass-type (G) wastes, metallic (M) wastes, combustible (C) wastes, silicate-adsorbed organic oils and solvents (S) wastes, and Portland cemented (P) wastes. The IWPF has not yet selected vendor partners because the selection will depend on the type of equipment that will provide the most optimum method to treat this mixed waste in the most cost-efficient manner with the minimum risk, that is, an optimized system design.

A basic objective is to have a very robust process and a durable, leach resistant waste form for the treated waste. INEL scientists and engineers have developed a promising glass-ceramic waste form called iron enriched basalt (IEB) for this mixed waste. IEB is a durable, leach resistant waste form capable of high waste loadings and large volume reductions. A high-temperature process $\left(>1600^{\circ} \mathrm{C}\right)$ must be used to produce the IEB.

\subsection{Melter System Preliminary Design Technical Review Meeting}

A preliminary design for a treatment system has been prepared that includes a plasma arc melter, offgas treatment, and material handling systems for processing stored waste into IEB. The AdvMWTP invited thermal processing experts representing multiple DOE consultants, and private sector vendor and engineering firms to review and comment on this preliminary system design. The focus was on the thermal treatment system; the related areas of waste characterization, retrieval, handling, and containment were not directly addressed at this time. The results from the melter system preliminary design technical review meeting will guide the AdvMWTP in selecting a system configuration for planned design and demonstration activities in FY-95 through FY-97. 
Personnel from DOE-ID, Lockheed Idaho Technologies and other DOE contractors, universities, DOD projects, thermal processing vendors, consultants, and contractors were invited to participate in this melter system design review meeting. The purpose for the meeting was two fold:

1. Exchange information and discuss various plasma arc melter design considerations for processing mixed radioactive waste (primarily alpha-contaminated low-level waste).

2. Provide guidance for the IWPF project in choosing a melter system configuration for planned design and demonstration activities in FY-95 through FY-97.

Justification of the review meeting is based primarily on the need to identify a melter system configuration early in FY-95 in order to design and demonstrate a system in FY-95 through FY-97. There are multiple DOE and DOD projects developing and evaluating thermal treatment processes for a variety of waste streams, and various thermal treatment process configurations are being considered. The IWPF project has collected available information and evaluated the various proposed thermal treatment processes against criteria developed by INEL scientists and engineers.

Time constraints limited the number of design topics that could be discussed at the review meeting. Discussion topics were introduced by personnel related to the IWPF project and were lead by a chair and co-chair with assistance from the meeting facilitator. Discussions were limited by time. Results, conclusions, recommendations, and unresolved issues were noted and are included in this review meeting summary.

The chair and co-chair for each topic subcommittee were responsible for collecting material, summarizing the discussions at the meeting, and noting unresolved issues. Each subcommittee has issued a letter report to cover the topics addressed at the review meeting. These reports are included in Appendices A through C. 


\section{SUMMARY OF INEL MIXED WASTE AND TREATMENT SYSTEM DEVELOPMENT}

Substantial quantities of mixed wastes are presently stored at the INEL. These wastes are very heterogeneous, and much of the wastes are not well characterized or packaged according to present standards for permanent disposal. There are many different waste streams, including large amounts of solid combustible materials (wood, paper, plastics, cloth, rags, etc), cemented and uncemented organic and inorganic sludges, metals, and other noncombustible, nonmetal materials (insulation, glass, soil, concrete, etc.) (Roesener and Soelberg 1992). Some of the waste is not segregated. It is anticipated that these wastes and contaminated soils will require treatment to remove or destroy hazardous organics and stabilize the radioactive and hazardous metal constituents. Treatment may also significantly reduce the final disposal volume.

\subsection{Definition of Terms}

Different types of radioactive and mixed wastes are defined in U.S. Department of Energy (DOE) Order 5820.2A, as follows:

\section{Radioactive Waste}

- High-Level Waste ( $H L W)$. The highly radioactive waste material that results from the reprocessing of spent nuclear fuel, including liquid waste produced directly in reprocessing and any solid waste derived from the liquid, that contains a combination of transuranic waste and fission products in concentrations requiring permanent isolation.

- Transuranic Waste (TRUW). Without regard to source or form, waste that is contaminated with alpha emitting transuranic radionuclides with half-lives greater than 20 years and concentrations greater than $100 \mathrm{nCi} / \mathrm{g}$ at the time of assay. Heads of field elements can determine that other alpha contaminated wastes, peculiar to a specific site, must be managed as transuranic waste. (TRUW: alpha $>100 \mathrm{nCi} / \mathrm{g}$; atomic \# > 92; half life > 20 years)

- Low-Level Waste (LLW). Waste that contains radioactivity and is not classified as high-level waste, transuranic waste, or spent nuclear fuel or $\Pi$ (2) byproduct material as defined by DOE ORDER 5820.2A. Test specimens of fissionable material irradiated for research and development only, and not for the production of power or plutonium, may be classified as low-level waste, provided the concentration of transuranic is less than $100 \mathrm{nCi} / \mathrm{g}$. LLW is any radioactive waste that is not identified as $\mathrm{HLW}$ or TRUW, with an alpha content of less than $100 \mathrm{nCi} / \mathrm{g}$.

Hazardous Waste. Those wastes that are designated hazardous by Environmental Protection Agency (EPA) regulations (40 CFR 261). For the AdvMWTP, this includes Resource Conservation and Recovery Act (RCRA)-listed or characteristic wastes and Toxic Substances Control Act (TSCA) wastes (primarily PCBs). 
Mixed Waste. Waste containing both radioactive and hazardous components as defined by the Atomic Energy Act and the Resource Conservation and Recovery Act, respectfully.

The terms alpha low-level waste (ALLW), reclassified transuranic waste, and orphan waste all refer to the present subset set of low-level waste ( $<100 \mathrm{nCi} / \mathrm{g}$ TRU), which contains less than $100 \mathrm{nCi} / \mathrm{g}$ and greater than $10 \mathrm{nCi} / \mathrm{g}$ of alpha emitting transuranic activity based on record keeping and assay at the time of disposal.

\subsection{Waste Types and Present Disposal Guidance}

Current guidance for the disposition of radioactive waste is based on the waste classification type. This guidance is summarized in Table 2-1. Mixed waste must be treated to satisfy RCRA regulations and meet requirements for land disposal restrictions (LDRs).

\subsection{Waste Streams of Concern}

INEL started receiving alpha-contaminated (transuranic) waste from the Rocky Flats Plant in 1954. Initially, the waste was disposed of in shallow land pits and trenches at the Subsurface Disposal Area (SDA). From 1960 to 1963, the alpha-contaminated waste from the Rocky Flats Plant was intermixed with INEL and commercially generated radioactive waste. Shallow land disposal ceased in 1970 when the INEL constructed the Transuranic Storage Area (TSA) and started to store the alpha-contaminated waste there for later retrieval.

The TSA consists of closed (bermed) cells, geofabric-covered areas, and an air supported building. Figures 2-1 and 2-2 show aerial views of the RWMC and TSA, respectively.

Table 2-1. Radioactive waste disposal options.

HLW

TRUW

LLW

Mixed LLW

Buried Wastes

ALLW or reclassified TRUW
Intense radioactivity with long-life elements, requires permanent isolation in a deep geological repository (Yucca Mountain)

Long-life TRU concentration $>100 \mathrm{nCi} / \mathrm{g}$, requires permanent isolation in a deep geological repository (Waste Isolation Pilot Plant-WIPP)

Low radioactivity, TRU concentration $<100 \mathrm{nCi} / \mathrm{g}$, land burial if stabilized LLW meets performance assessment per 5820.2A (TRU concentration <10 nCi/g at INEL RWMC) and is not mixed

Mixed low-level wastes require treatment for RCRA/TSCA hazardous constituents for land disposal (meet LDRs)

Contain TRUW, LLW and mixed wastes-Treatment and disposal methods have been or are defined by the CERCLA process.

With a TRU concentration $>10 \mathrm{nCi} / \mathrm{g}$ but $<100 \mathrm{nCi} / \mathrm{g}$, no disposal method or site has been defined 


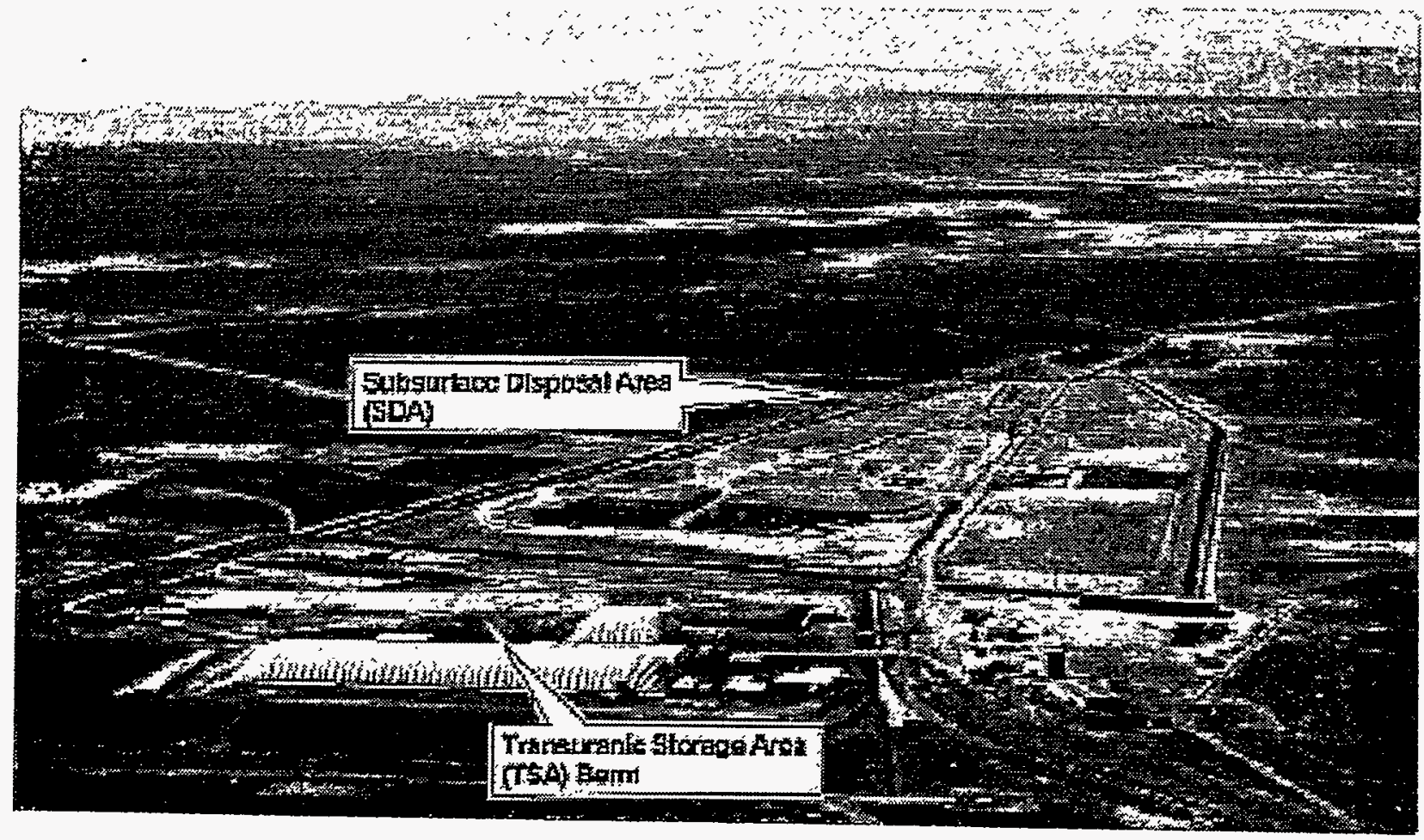

Figure 2-1. Aerial view of the INEL RWMC, TSA, and the SDA.

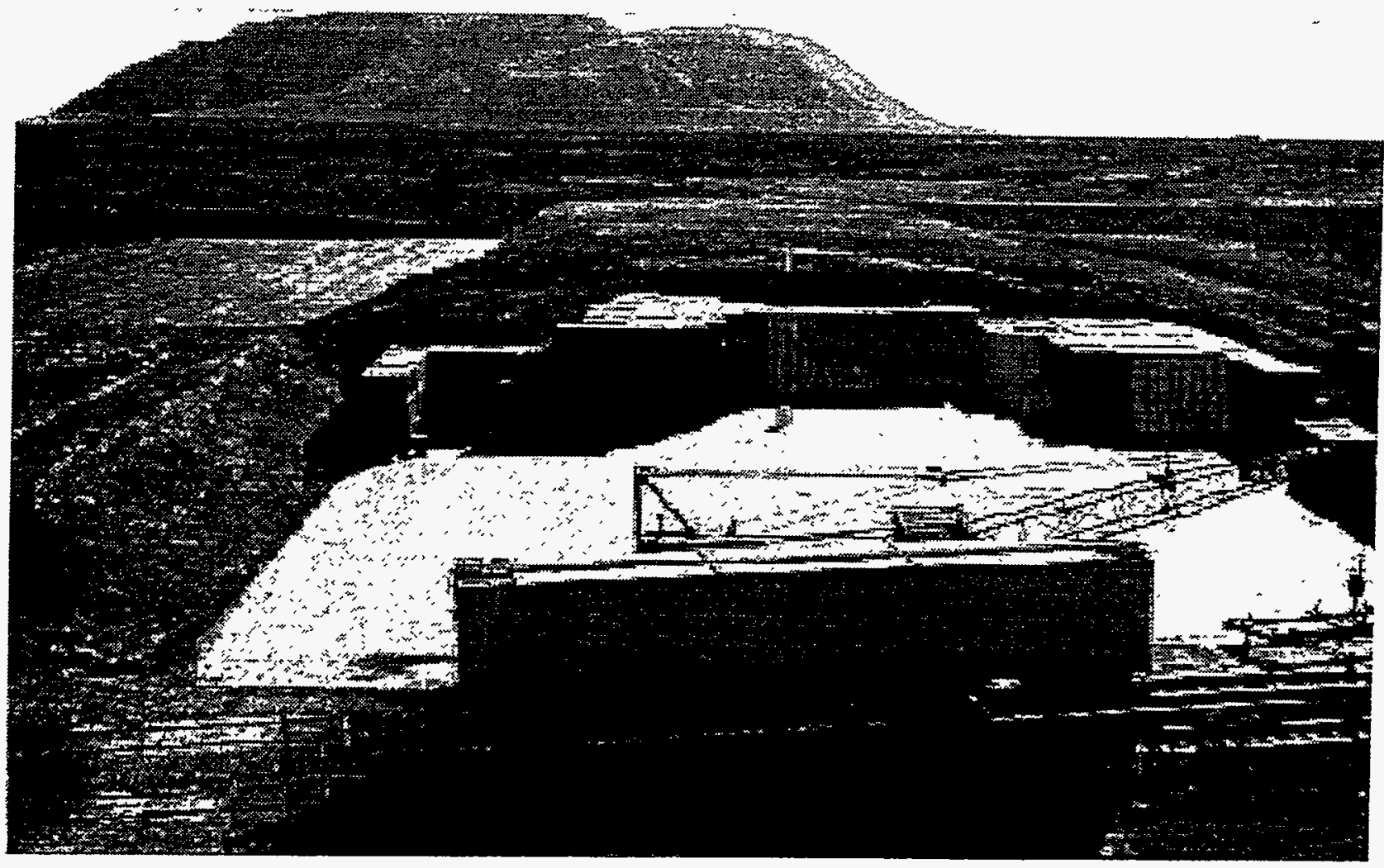

Figure 2-2. TRU waste in retrievable storage. 
The INEL currently has the majority of alpha-contaminated waste generated by DOE. Ninety percent of the current alpha-contaminated total waste inventory at the INEL was generated at the Rocky Flats Plant near Golden, Colorado. The other $10 \%$ is from various other DOE laboratories, universities, and miscellaneous sources. Table 2-2 summarizes information for the waste streams of concern.

The current primary waste streams of concern for the AdvMWTP are the alpha-contaminated stored wastes located at the TSA. The total inventory of alpha-contaminated waste at the TSA is estimated to be approximately $65,000 \mathrm{~m}^{3}\left(2.3\right.$ million $\left.\mathrm{ft}^{3}\right)$. The definition of transuranic waste (TRUW) was changed in the early 1980s from greater than $10 \mathrm{nCi} / \mathrm{g}$ to greater than $100 \mathrm{nCi} / \mathrm{g}$, resulting in a subset of waste previously classified as transuranic but reclassified to low-level waste (more specifically ALLW, reclassified TRUW, or orphan waste). The waste type distribution is estimated to be approximately $60 \%$ TRUW and $40 \%$ LLW (less than $100 \mathrm{nCi} / \mathrm{g}$ ). Of the estimated $40 \% \mathrm{LLW}, 90 \%$ is estimated to be greater than $10 \mathrm{nCi} / \mathrm{g}$ (i.e., ALLW, reclassified or orphan waste). All of the TSA wastes are considered to be mixed wastes. Approximately $58 \%$ of the TSA waste is stored in boxes or bins. Figure 2-3 presents the current estimated waste inventory for the TSA stored wastes by container type and location.

The wastes from the Rocky Flats operations are typically heterogeneous solid wastes (debris, rags, papers, metals, sludges, glass, wood, graphite, concrete, soil, asphalt, resins, etc.), contaminated with alpha emitting (transuranic) radionuclides and RCRA-regulated constituents. Figures 2-4 and 2-5 illustrate this waste in drums and boxes.

\subsection{The Problem}

There is no near-term treatment or ultimate disposal facility identified for alphacontaminated mixed low level waste. The mixed waste must be treated for disposal according to RCRA LDR requirements for hazardous constituents, and it must meet disposal performance assessments for radionuclides in accordance with DOE Order 5820.2A. No final disposal location has been identified.

INEL has approximately $80 \%$ by volume of the DOE inventory of alpha-contaminated mixed low-level waste in temporary retrievable storage. No existing facility is capable of treating this waste. Treatment technologies and processes must be developed and demonstrated.

Table 2-2. Waste streams of concern.

Buried Wastes Alpha-contaminated wastes buried at the SDA from 1952 to 1970.

Approximately 57,000 cubic meters of wastes are in the form of drums, boxes, large debris, and specialty objects buried in shallow pits and trenches. In addition, there are greater than 200,000 cubic meters of contaminated soils.

Stored Wastes Retrievably stored alpha contaminated wastes at the TSA (since 1970), approximately 65,000 cubic meters of drums, boxes, and bins 

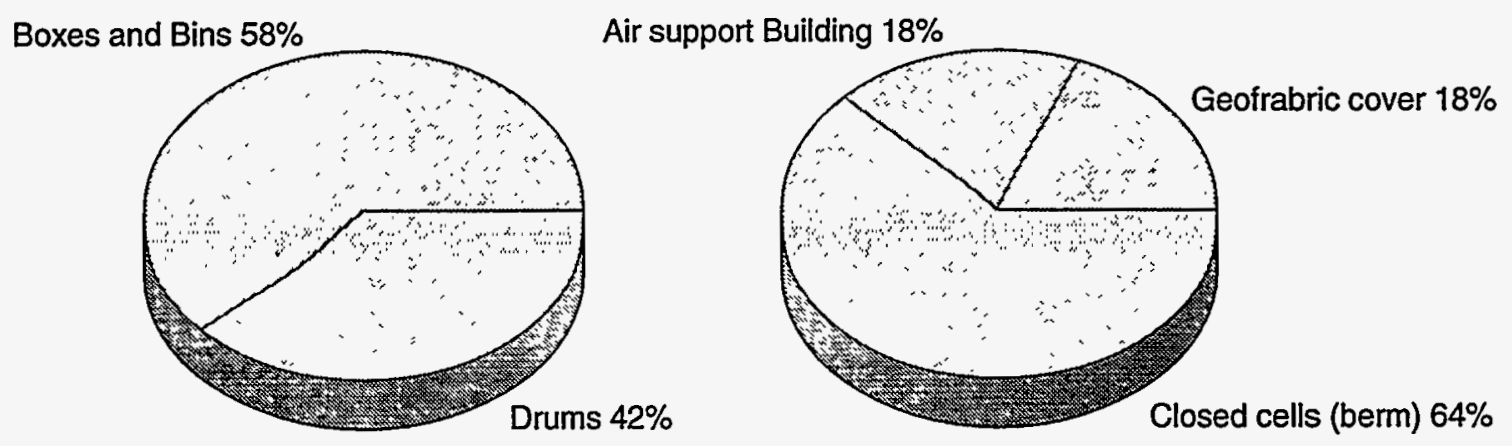

N95 0022

Figure 2-3. Present TSA stored waste inventory totals approximately $60,000 \mathrm{cu}$ meters (2.3 m cu ft).

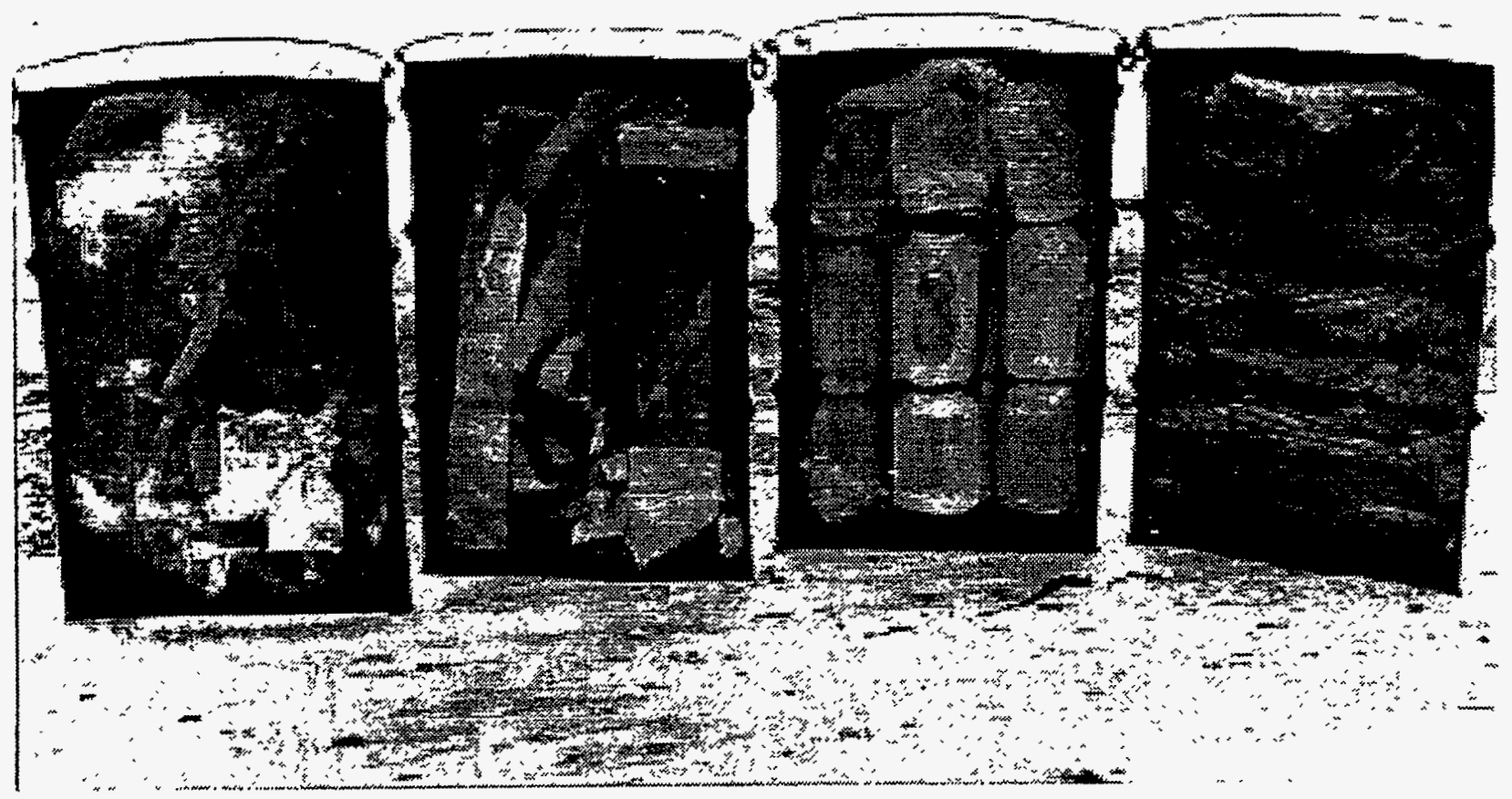

Figure 2-4. INEL stored waste drums containing clothing, plastic, metals, glass, and process sludges. 


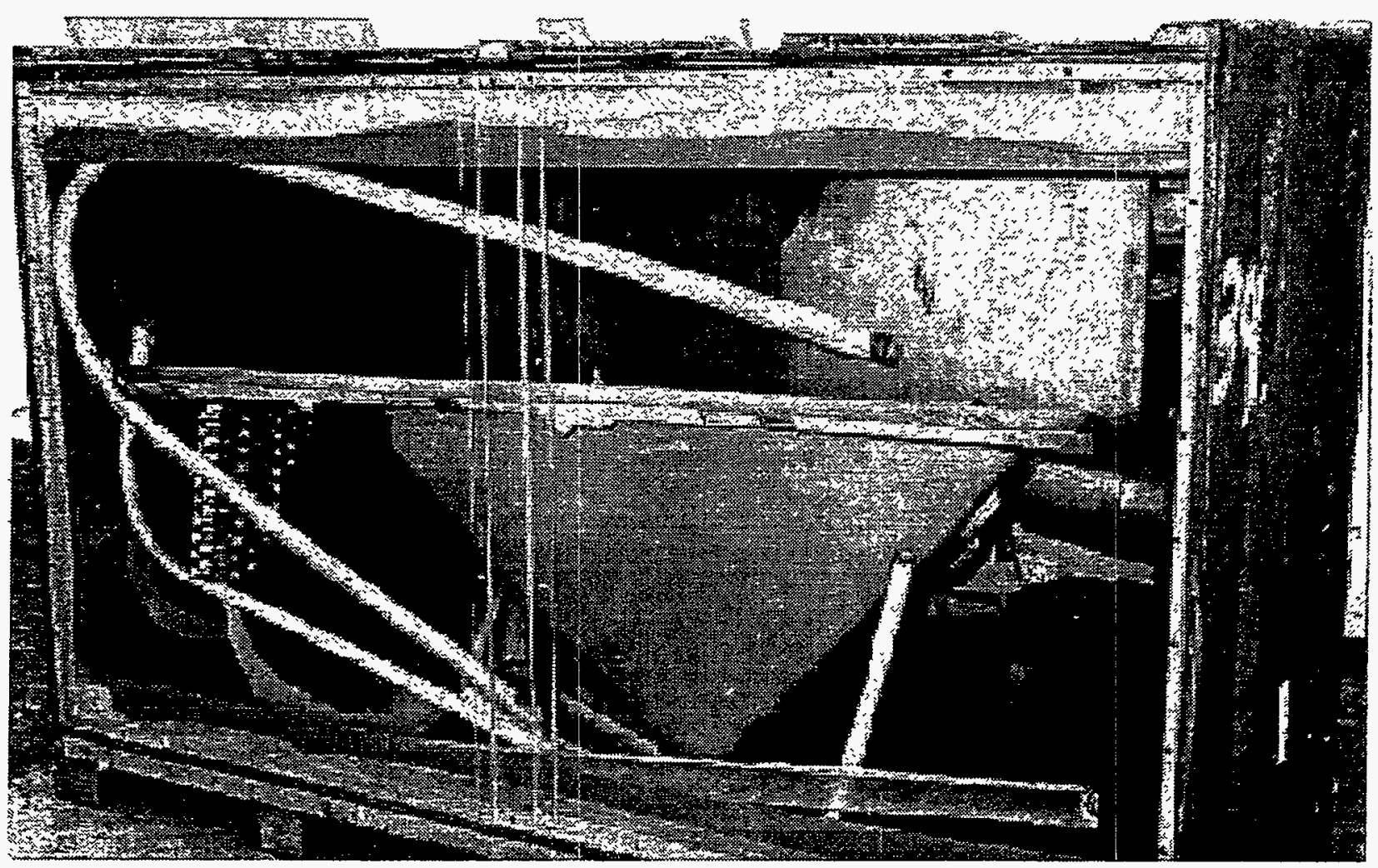

Figure 2-5. Fifty-eight percent of INEL stored waste is in bins and boxes.

Some unknown quantity of the currently classified TRUW (greater than $100 \mathrm{nCi} / \mathrm{g}$ ) will also require characterization and treatment to some degree to meet the Waste Isolation Pilot Plant (WIPP) Waste Acceptance Criteria (WAC).

The WAC for the proposed WIPP has not as yet been finalized. At a minimum, some of the existing waste must be sorted and repackaged before being sent to WIPP. Further, the current WIPP WAC assumes a "no migration petition," which is essentially an exemption from EPA LDRs, will be granted. Future performance assessments and reviews may, in reality, lead to more restrictive WACs, which again may delay the opening of WIPP. In addition, INEL buried waste disposition under the CERCLA guidance may require ex-situ treatment and disposal. No location has been identified for ex-situ treatment.

\subsection{Strategies for Solution}

Various independent preliminary systems design studies have been completed to scope waste treatment system alternatives, economics, and technology development needs. Table 2-3 presents a list of reports from melter system scoping and background studies. These include various strategies for degree and method of treatment and ultimate disposal of stored and buried mixed alpha-contaminated wastes being considered at the INEL. No final decisions have yet been made.

The AdvMWTP, or an optional private sector treatment project, is identified in the INEL Waste Management Plans (Waste Management Strategic Plan, DOE/ID, 10429, June 1994; and FFCA Draft Site Treatment Plan, September 1994) to treat the alpha-contaminated (mixed) low 
level wastes, the transuranic wastes if treatment is required, and, potentially, the retrieved buried waste.

Under the AdvMWTP, a melter-based thermal treatment process as the primary treatment concept has been evaluated for the Idaho Waste Processing Facility. Various preconceptual design and development issues have been identified and supporting tasks begun based on scoping studies.

These scoping studies identified that high-temperature electric-melter-based thermal treatment systems ranked high for treatment of the INEL alpha contaminated waste and other similar waste. High-temperature treatment systems enable the following:

- Complete waste material breakdown and inherent thermal separations (slag, reduced metals, minimal offgas) and production of homogenous products

- Destruction of hazardous organics

- Large volume reductions of solid waste

- Immobilization of actinides and oxidized metals in nonleachable geologically durable glass/ceramic final waste forms (IEB)

- $\quad$ Robust processing, with wide ranges of feed acceptance and process variation tolerances

- Use of industrial equipment experience based on similar nonradioactive heterogenous materials

- Similar or equivalent life cycle costs for the treatment system itself when compared to other processes, and lower total life cycle costs when transportation and disposal costs are factored into the economics.

Table 2-3. Melter system scoping studies.

Buried Waste, BWID SDS

Melter Development Needs Assessment

Thermal Processing Concepts for Buried Waste

Stored Waste, ALLW SDS

AdvMWTP Process System and Facilities Study

IWPF Treatment Process Preconceptual Study

MWIP IER on Thermal Technologies

Integrated Thermal Treatment System Study-Phase I
EGG-WTD-9594, 7/91

EGG-WTD-9911, 9/91

EGG-WTD-10058, 2/92

EGG-WTD-10254, 8/92

ORNL/LLNL/Bechtel, 9/92

WM-PD-92-009, 9/92

DOE-MWIP-2, 2/93

EGG-MS-11211, 7/94 
The AdvMWTP (EM-30 funded) is monitoring and integrating other thermal treatment development and demonstration programs to leverage funding and exchange information. Table 2-4 presents a list of other thermal treatment development and demonstration programs (non-EM-30 funded) that the AdvMWTP is monitoring or collaborating with.

As designated owners of the INEL's alpha-contaminated mixed waste and the responsible party for the construction, safe operation, and execution of Waste Management's ultimate decisions for treatment strategy via a government facility (as opposed to the alternate private sector solution), the AdvMWTP must take the next steps to design and demonstrate a production melter system for these wastes at the INEL.

Review of melter system technology development status, supporting bases, and technical plans was the focus of the October 1994 technical review workshop and this summary report.

Table 2-4. Melter system development and demonstration programs.

PNL/MTT/EPI, Graphite dc Arc melter and in situ Real-Time OTD-BWID, EM-50 funded Measurements

INEL/USBM, ac Arc Melter Vitrification

OTD-BWID, EM-50 funded

SAIC/INEL, Plasma Hearth (PHP)

OTD-MWIP, EM-50 funded

MSE/INEL/Retech, Plasma Centrifugal Reactor (PCR)

OTD-BWID, EM-50 funded

Demonstration

Lockheed/Retech/INEL/Pit 9 ER PCR Demonstration

ER, EM-40 funded

PNL high temperature ceramic electrode JHM

OTD, EM-50 funded 


\section{VITRIFICATION OF COMMERCIAL AND INDUSTRIAL WASTES}

The concept of vitrification to stabilize hazardous commercial and industrial waste streams is becoming more commonplace with the increase in landfill costs and the recent landfill bans put in place by various governments. New disposal regulations are increasing the costs for, or are eliminating, traditional disposal methods. This makes vitrification more economically viable, as well as more environmentally stable. Some vitrified materials may even be convertible into delistable materials that do not need to be placed in a repository.

The types of waste being considered for possible thermal treatment are the following:

- Municipal solid waste incinerator ash

- Refuse-derived fuel ash

- Asbestos insulation

- Hospital waste

- Electric arc melter dust and slag

- Commercial nuclear reactor wastes

- DOE mixed low-level and TRU-contaminated waste

- Military wastes, including munitions and propellants.

The following discussion includes some commercial, industrial, and nuclear applications, with some composition and cost considerations. A recent study of electric arc melter dust treatment processes is then discussed in more detail to indicate the level of development in the 1-5 MW $(1-5$ ton/h) size plasma arc melters.

\subsection{Commercial Applications}

Commercial applications of plasma arc melter systems to stabilize wastes include the following:

- Municipal Incinerator Ash. A consortium including the American Society of Mechanical Engineers and the U.S. Bureau of Mines (USBM) performed a study at the USBM in Albany, Oregon, to treat municipal solid waste incinerator ash (Oden and O'Connor 1994). An 800-kW 3-phase ac arc melter with graphite electrodes and refractory walls was used to melt up to $1,700 \mathrm{lb} / \mathrm{h}$ of ash. The presized waste was transported to the facility in bags, emptied into hoppers and fed into the melter through four vertical (now water-cooled) feed tubes bottoming near the melt region. Figure 3-1 is a schematic diagram of the feed, melting, and fume systems for the ASME tests. 


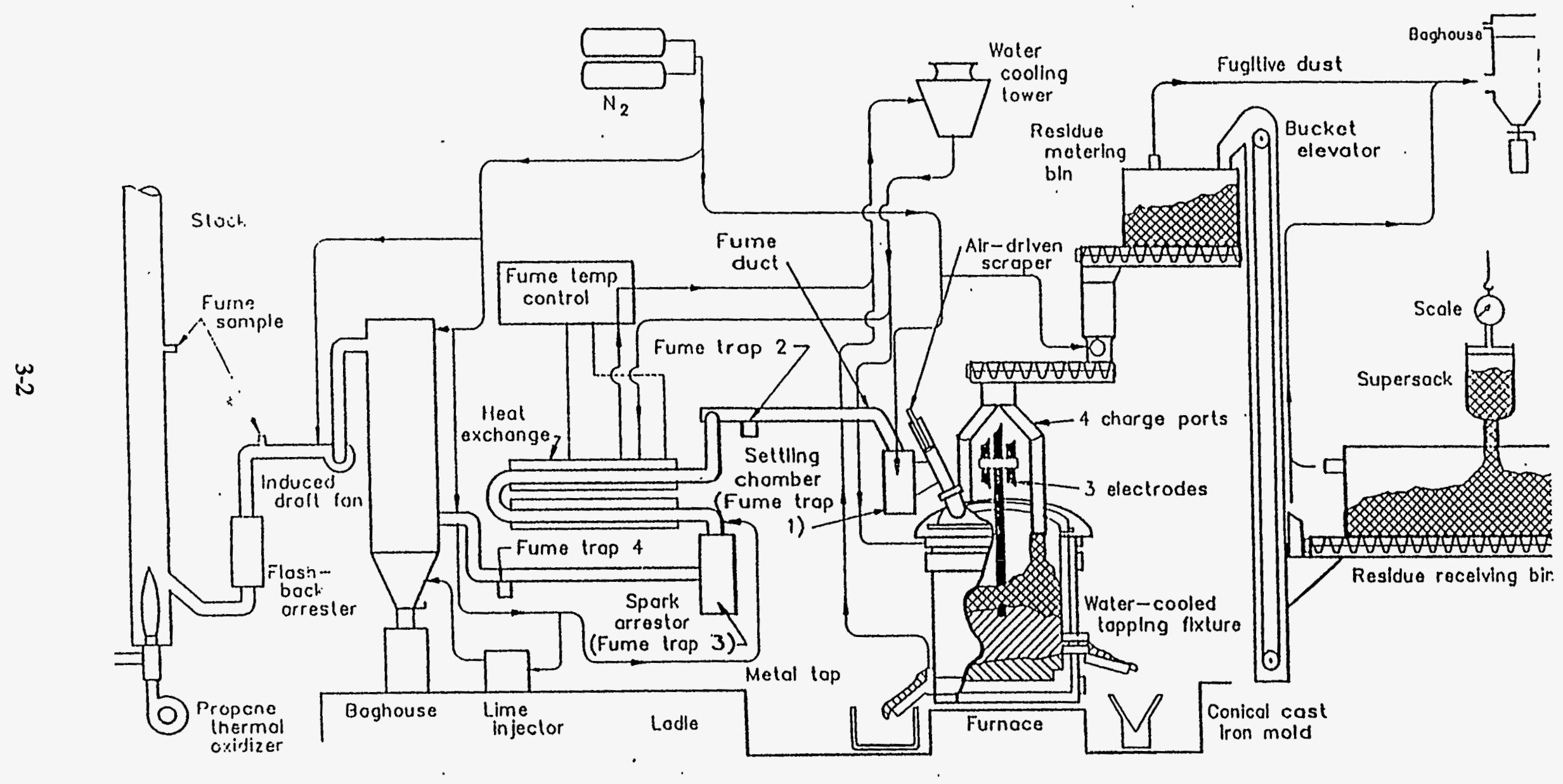

Figure 3-1. The USBM 3-phase ac arc melter system as used for the ASME tests (Oden and O'Connor 1994). 
- Refuse-Derived Fuel Ash. Southern California Edison (Sciarrotta 1994) is studying vitrification of refuse-derived fuel ash using the same U.S. Bureau of Mines (USBM) melter system in Albany as a piggyback operation to the INEL studies on DOE ALLW/TRUW. Figure 3-2 shows the USBM system as modified for the INEL and Southern California Edison tests (Soelberg, et al., 1994).

- Asbestos Stabilization. The Electricité de France helped form the INERTAM Company to process asbestos pipe insulation from a decommissioned nuclear power plant at Arjuzanx, France (Francois 1994). The system is modular so it can be transported at the end of a campaign. Two bound 55-gal barrels of asbestos insulation plus other materials are dropped into a molten pool of slag, are melted by a 2-MW nontransferred Aerospaciale torch operating on air and tapped into ingots or made into a frit. The offgas system is a dry system with a secondary combustor, a spray and air quench, and appropriate particulate filters. The system is operating daily with a planned throughput of $1 \mathrm{MT} / \mathrm{h}$. Figure 3-3 shows a schematic of the INERTAM system.

- Hospital Waste Processing. Plasma Energy Applied Technology is installing a $1,000 \mathrm{lb} / \mathrm{h}$ system at the Kaiser Permanente, San Diego Medical Center (Springer and Burns 1993). The system uses a transferred plasma torch in a refractory lined chamber. The slag produced is a glassy rock. The offgas can be burned or recycled, e.g., in a cogeneration system. Figure 3-4 shows a schematic of the PEAT system.

\subsection{Industrial Applications}

Industrial applications of plasma arc technology for waste treatment include the treatment of electric arc furnace (EAF) dust. Treatment of EAF dust is discussed in more detail in Section 3.5 because of its relevance to the main theme of this report. Most of the discussion is based on an EPRI/CMP report on this topic (Bosley 1992). EAF dust treatment processes include

- Elkem high-temperature metal recovery system

- Davy-McKee Hi-Plas system

- International Milling Machine torch/graphite plasma melter

- $\quad$ Pyromet-Mintek plasma-arc system

- Ticron extended plasma-arc reduction system.

The size range for these units is typically 1-5 MW. Because the melters process hazardous materials, they are completely closed and have offgas systems for controlling air emissions and recovering valuable materials, such as zinc in EAF dust. Several of these units have been put into operation, but the low price of zinc has resulted in closure for economic reasons. Nevertheless, the cost of thermal stabilization (about $\$ 300-350 /$ ton) is close to that for disposal in a hazardous material landfill (about $\$ 200 /$ ton). Current changes in landfill regulations appear to be shifting the interest toward stabilization even without the added economic benefit of zinc recovery. 


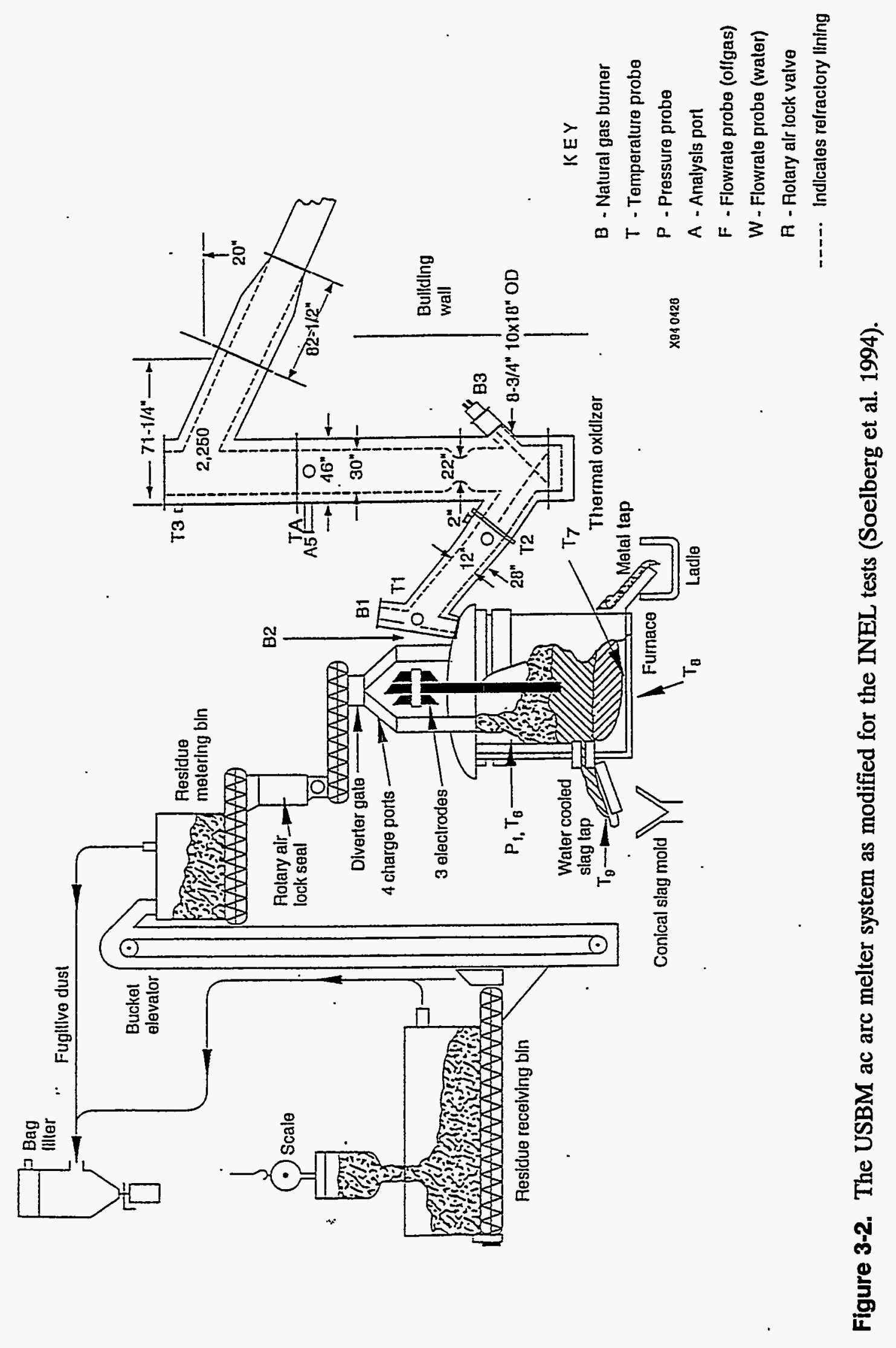




\section{SCHÉMA \\ DE L'INSTALLATION}

is

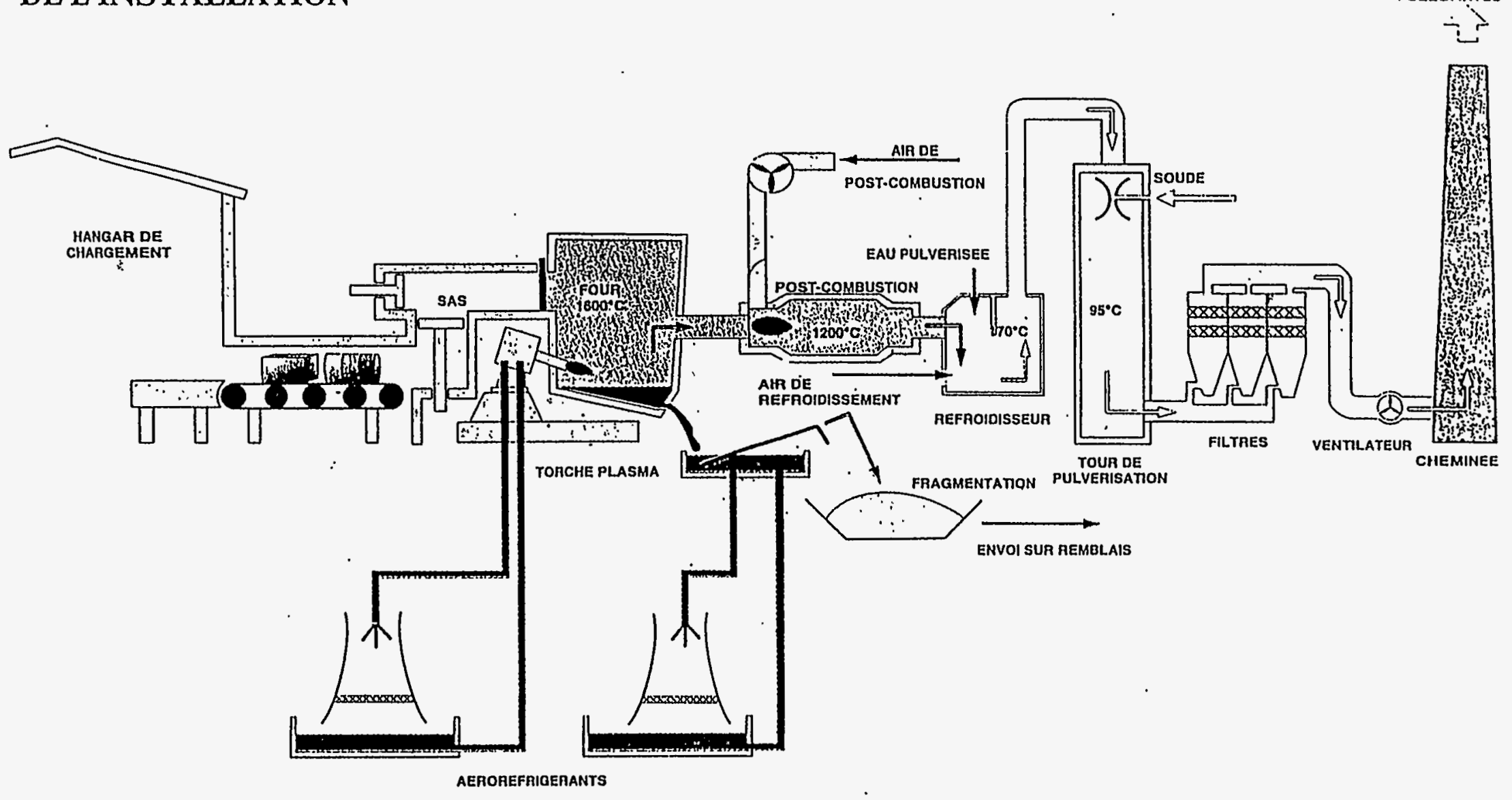

Figure 3-3. The INERTAM dc nontransferred torch system (Francois 1994). 
(6)

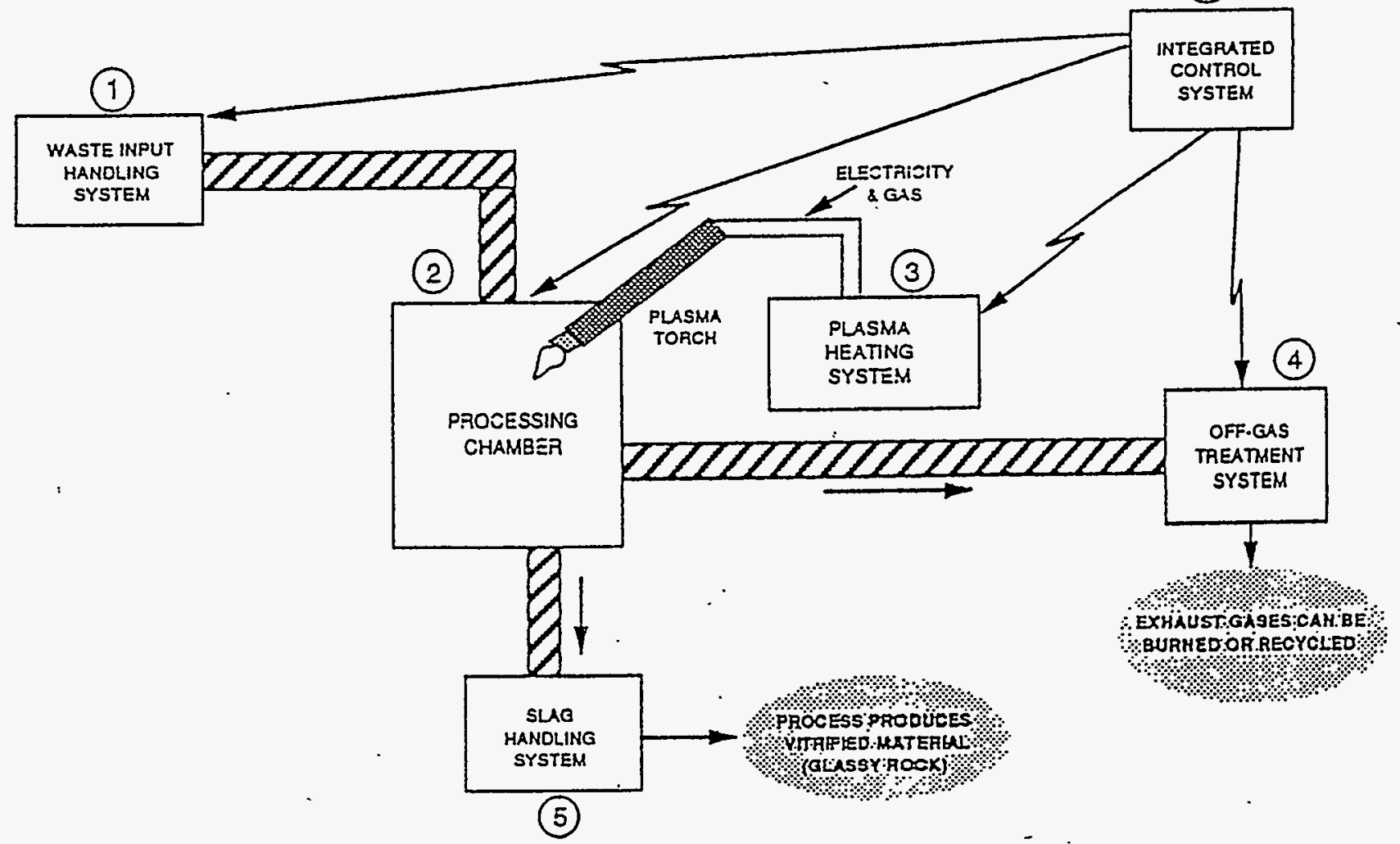

Figure 3-4. Concept of the PEAT dc nontransferred plasma torch system (Springer and Burns 1994).

The status of vitrification of industrial incinerator and boiler ash and EAF slags is similar to that for EAF dust. There is less opportunity for recovery of valuable metals, but the products can be delisted. The delisted products can be used for a variety of construction applications and do not have to be sent for disposal. Products for commercial use are being developed by Oregon Steel Mills in Portland using a high-temperature Joule-heated melter (Gordon 1994).

\subsection{Radioactive Waste Applications}

Radioactive waste applications include commercial nuclear reactor wastes, DOD and DOE nuclear reactor wastes, and nuclear weapon waste materials. For high-level (radioactive) wastes, final waste forms of borosilicate glass made in Joule-heated melters have been the approved waste form. Plasma arc melters are presently being considered for the DOE LLW, ALLW, and TRUW, as well as the Nuclear Regulatory Commission (NRC) LLW, and the Greater-Than-Class-C (GTCC) LLW because of their robustness for treating heterogeneous wastes and for the higher temperatures required for some waste compositions and for metals (iron). Other intermediate level wastes could be considered as applications, but only in smaller size melters because of criticality or other radiation safety considerations. 
At present, DOE is funding a number of demonstrations to treat ALLW and TRUW at the INEL, as indicated in Table 3-1. The Savannah River Site is considering treating some Pucontaminated wastes. The Hanford site is considering treating sodium-bearing liquid wastes. Smaller bench-scale testing is also being performed at most of these and other locations. In addition to the USBM, INTERTAM, and PEAT systems shown in Figures 3-2, 3-3, and 3-4, schematics of the plasma centrifugal reactor (PCR), the dc graphic arc melter, and the plasma hearth process (PHP) are shown in Figures 3-5, 3-6, and 3-7, respectively.

\subsection{Military Waste Applications}

Vitrification and pyrolysis of military wastes has been under investigation for several years. The U.S. Navy has been studying pyrolysis and vitrification of the ash to reduce on-board wastes and to satisfy the international ban on dumping wastes into the ocean. The U.S. Army has been investigating arms, chemicals, and classified components. The U.S. Air Force is involved in related studies.

\subsection{Applicability and Costs}

Compositions of the electric arc melter dust and slag are very similar to the INEL average TRUW final waste form compositions on which much research has been done. Municipal ash compositions are also similar to INEL average TRUW final waste form compositions. The TRUW final waste forms are extremely stable. Work on stabilization, recycling, and reclamation developed at the INEL can be used for private sector applications as well.

The estimated costs and savings from vitrification of low-level waste have been estimated by Bickford (Bickford 1993), as shown in Table 3-2. The volume reduction effects can be considerable, resulting in substantial disposal and, hence, life cycle cost savings. Phenomenal savings can be obtained from vitrification and delisting.

Figure 3-8 presents a conceptual plot of cost per unit volume as a function of different types of waste and their probable repositories. The dashed curve represents an estimate of the current disposal cost per original volume for given waste streams. The solid curve represents the estimated disposal cost per reduced volume after going through a melting treatment. EAF dust treatment and disposal is an example of the critical crossover point in commercialization. Traditional disposal costs are approximately $\$ 200 /$ ton with melter treatment at $\$ 300-350 /$ ton; hence, EAF dust treatment is precluded unless the zinc can be recovered for a profit.

Not illustrated explicitly is the value added if the waste can be reused and not have to be disposed. It is included implicitly as the dashed line. The savings is the unspent disposal cost plus the value-added product. 
Table 3-1. Brief descriptions of the pilot-scale plasma/arc-heated melters being studied by DOE for the treatment of radioactive wastes.

\begin{tabular}{|c|c|c|c|c|}
\hline & $\begin{array}{l}\text { MSE/Retech/LESAT, } \\
\text { Butte, MT }\end{array}$ & $\begin{array}{l}\text { ASME/INEL/USBM, } \\
\text { Albany, } \text { OR }^{\text {b }}\end{array}$ & $\begin{array}{l}\text { PNL/EPI/MTT, } \\
\text { Cambridge, MA }\end{array}$ & $\begin{array}{l}\text { MWIP/SAIC/Retech, } \\
\text { Ukiah, CA }\end{array}$ \\
\hline Identity & $\begin{array}{l}\text { Plasma centrifugal } \\
\text { reactor (PCR) } \\
\text { (Figure 3-5) }\end{array}$ & $\begin{array}{l}\text { ac arc melter } \\
\text { (Figure 3-2) }\end{array}$ & $\begin{array}{l}\text { dc graphite arc } \\
\text { melter (Figure 3-6) }\end{array}$ & $\begin{array}{l}\text { Plasma hearth process } \\
\text { (PHP) (Figure 3-7) }\end{array}$ \\
\hline Input waste streams & $\begin{array}{l}\text { Soil, oil, iron, wood } \\
\text { chips, surrogates, } \\
\text { stainless steel }\end{array}$ & $\begin{array}{l}\text { Municipal incinerator } \\
\text { ash, BWID std. } \\
\text { waste streams }\end{array}$ & $\begin{array}{l}\text { Minibags of BWID } \\
\text { std waste streams }\end{array}$ & $\begin{array}{l}\text { Minibarrels of simulated } \\
\text { TRUW waste }\end{array}$ \\
\hline Capacity & $<300 \mathrm{lb} / \mathrm{h}$ & $<1700 \mathrm{Ib} / \mathrm{h}$ & Unknown & Unknown \\
\hline Sizing system & None in system & None in system & $\begin{array}{l}\text { None needed or in } \\
\text { system }\end{array}$ & None needed or in system \\
\hline Feed system & $\begin{array}{l}\text { Archimedes screw and } \\
1 \text { gravity tube }\end{array}$ & $\begin{array}{l}\text { Auger screw \& } \\
4 \text { gravity tubes }\end{array}$ & $\begin{array}{l}\text { Minibags or barrels } \\
\text { fed via slide gates }\end{array}$ & Minibarrels are ram fed \\
\hline Incinerator & None & None & None & None \\
\hline Melter & $\begin{array}{l}0.5-\mathrm{MW} \text { dc plasma } \\
\text { torch, refractory-lined } \\
\text { water-cooled rotating } \\
\text { chamber }\end{array}$ & $\begin{array}{l}0.8-\mathrm{MW} \text { 3-ph ac, } \\
\text { graphite electrodes, } \\
\text { gravity water-cooled } \\
\text { refractory-lined fixed } \\
\text { chamber }\end{array}$ & $\begin{array}{l}\text { 1-MW dc graphite } \\
\text { electrode(s) and } \\
\text { graphite fixed } \\
\text { chamber }\end{array}$ & $\begin{array}{l}0.5-\mathrm{MW} \text { dc plasma torch, } \\
\text { refractory walls, } \\
\text { conducting refractory or } \\
\text { metal bottom }\end{array}$ \\
\hline Final waste forms & $\begin{array}{l}\text { Tap IEB waste from } \\
\text { center hole at slow } \\
\text { rpm; secondary waste } \\
\text { form small }\end{array}$ & $\begin{array}{l}\text { Tap IEB and (iron) } \\
\text { metal from fixed taps }\end{array}$ & $\begin{array}{l}\text { Tap IEB via } \\
\text { submerged wier, no } \\
\text { metal tap }\end{array}$ & $\begin{array}{l}\text { Tap IEB from submerged } \\
\text { wier and metal from fixed } \\
\text { tap }\end{array}$ \\
\hline $\begin{array}{l}\text { Secondary } \\
\text { combustor }\end{array}$ & $\begin{array}{l}\text { Main combustion is in } \\
\text { melter; completes } \\
\text { combustion }\end{array}$ & $\begin{array}{l}\text { Limited combustion } \\
\text { studies to date; } \\
\text { combusts pyrolyzed } \\
\text { gases }\end{array}$ & $\begin{array}{l}\text { Combusts pyrolyzed } \\
\text { gases }\end{array}$ & $\begin{array}{c}\text { Unknown } \\
\text {. }\end{array}$ \\
\hline Offgas system & $\begin{array}{l}500 \text { acfm, spray } \\
\text { quench, venturi } \\
\text { scrubber, baghouse, } \\
\text { charcoal filter, HEPA } \\
\text { filters }\end{array}$ & $\begin{array}{l}5000 \text { acfm, spray \& } \\
\text { air dry quench, } \\
\text { cyclone, baghouse, } \\
\text { gas jet scrubber, } \\
\text { charcoal filter, } \\
\text { HEPA filter }\end{array}$ & Unknown & $\begin{array}{l}\text { Spray quench, baghouse, } \\
\text { charcoal \& HEPA filters, } \\
\text { Caustic \& acid scrubbers, } \\
\mathrm{NO}_{\mathrm{x}} \text { abatement }\end{array}$ \\
\hline Comments & Oxidizes stainless steel & $\begin{array}{l}\text { High throughput for } \\
\text { size, nearly complete } \\
\text { full-scale system }\end{array}$ & $\begin{array}{l}\text { No water cooling of } \\
\text { chamber, reduces } \\
\text { melt, treats larger } \\
\text { objects }\end{array}$ & Treats larger objects \\
\hline \multicolumn{5}{|c|}{ a. Whitworth et al. 1992.} \\
\hline \multicolumn{5}{|c|}{ b. Soelberg et al. 1994.} \\
\hline \multicolumn{5}{|c|}{ c. Watkins et al. 1993.} \\
\hline d. Mixed Waste Inte & grated Program 1994. & & . & \\
\hline
\end{tabular}


Table 3-2. Estimated cost savings on treatment options of SRS mixed LLW.

\begin{tabular}{lcr}
\multicolumn{1}{c}{ Option } & $\begin{array}{c}\text { Volume } \\
\text { reduction }\end{array}$ & $\begin{array}{c}\text { Disposal cost/yr } \\
(\$)\end{array}$ \\
\hline Mixed LLW & 0 & \\
$66,800 \mathrm{ft}^{3}$ cement/yr & $80 \%$ & $\$ 6,700,000$ \\
Treat and cement & $88 \%$ & $1,400,000$ \\
Evaporate and solidify & $97 \%$ & 800,000 \\
Glassify & & 200,000 \\
WW Sludge & 0 & \\
Cement & $50 \%$ & $\$ 32,000,000$ \\
Treat and cement & $97 \%$ & $16,000,000$ \\
Glassify & $97 \%$ & $1,700,000$ \\
Glassify and delist & & 500,000 \\
\hline
\end{tabular}

a. Bickford 1993.

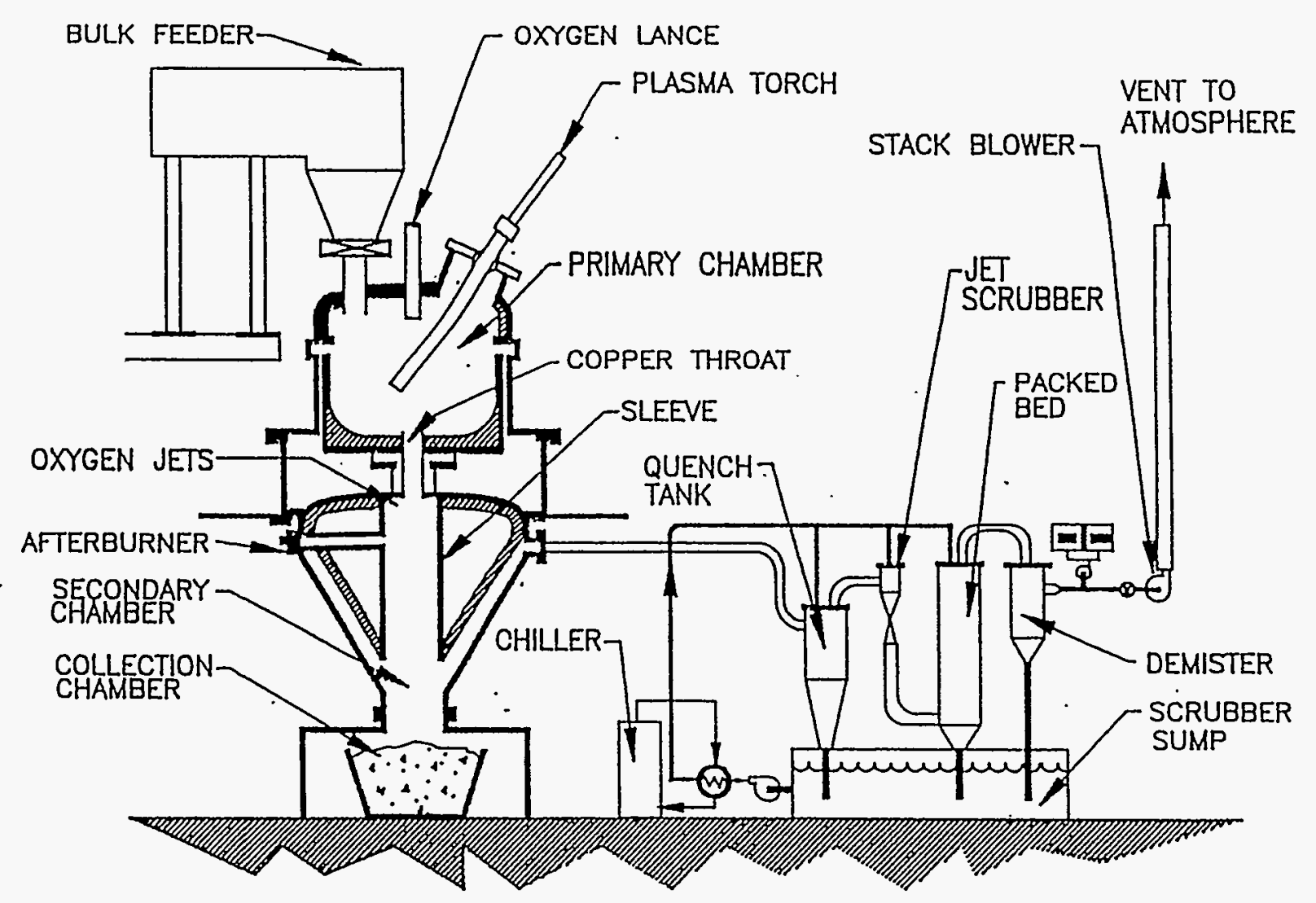

Figure 3-5. The MSE/Retech dc plasma centrifugal reactor system (Whitworth et al. 1992). 


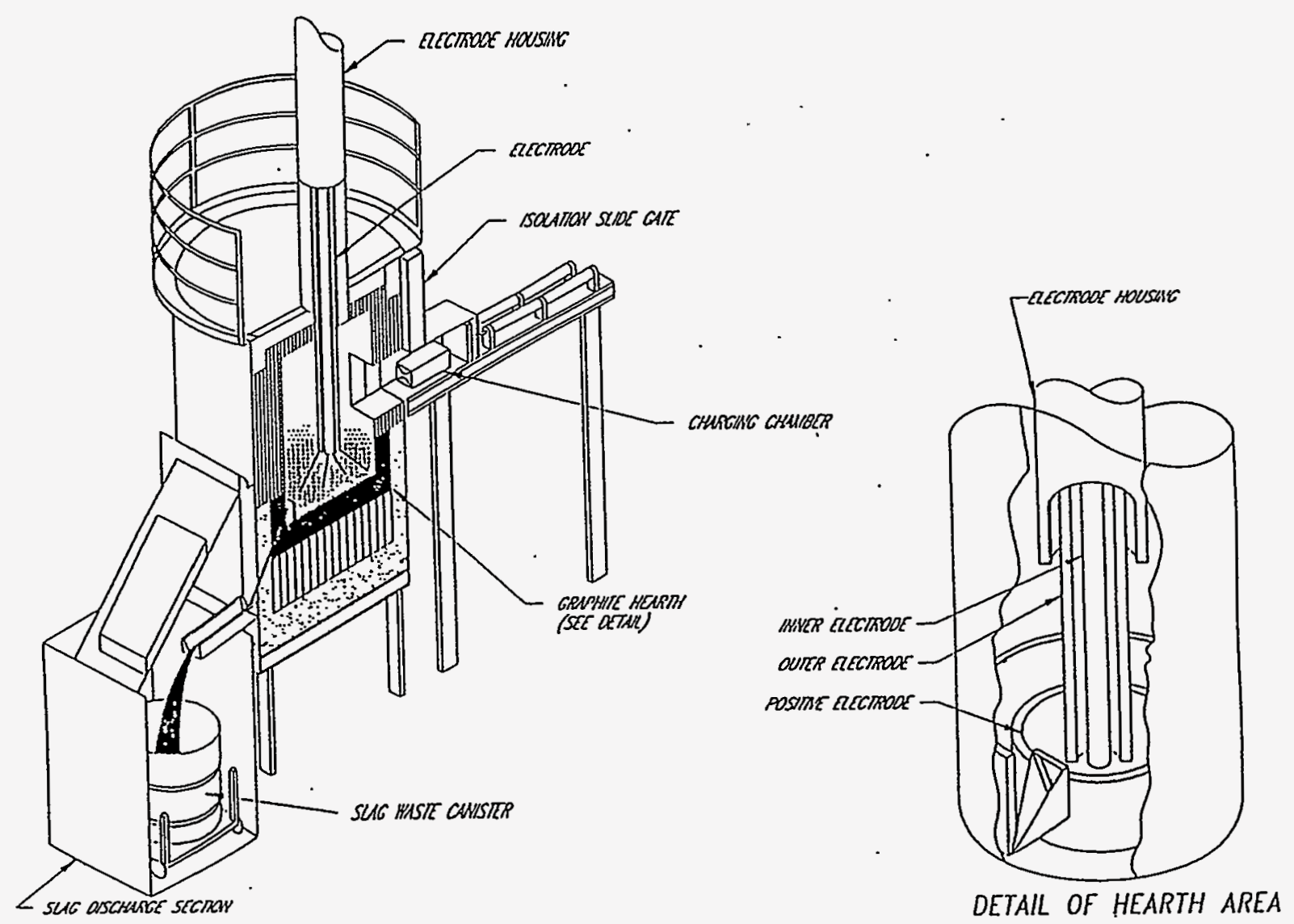

Figure 3-6. The EPI/MTT Mark II DC graphite electrode and hearth arc melter (Watkins et al. 1993).

\subsection{Electric Arc Melter Dust Treatment}

EAF dust is a hazardous waste (EPA designation K061). A number of the EAF dust treatment processes have melters in the 1-5 MW (1-5 Ton/h) (Bosley 1992) size range being considered for treating DOE mixed wastes. Since hazardous wastes are being treated, the units are closed or air tight. Most of the units are pilot plants or have been installed in service for treating EAF dust, electroplating wastes (EPA F006), or inorganic transition metals (EPA D004, D005, D006) and contain all or more of the hazardous metals of concern at the INEL. The installations are complete systems, including pretreatment, melting, recovery of recyclable materials, offgas collection, and disposal considerations. The last includes land disposal and RCRA constraints or recycling as construction products or mineral wool (a calcium-based fiberglass) for insulation purposes.

The applications included here are from Bosley (1992). They include the following:

- Elkem high-temperature metal recovery system (Figure 3-9)

- Davy-McKee Hi-Plas system (Figure 3-10) 


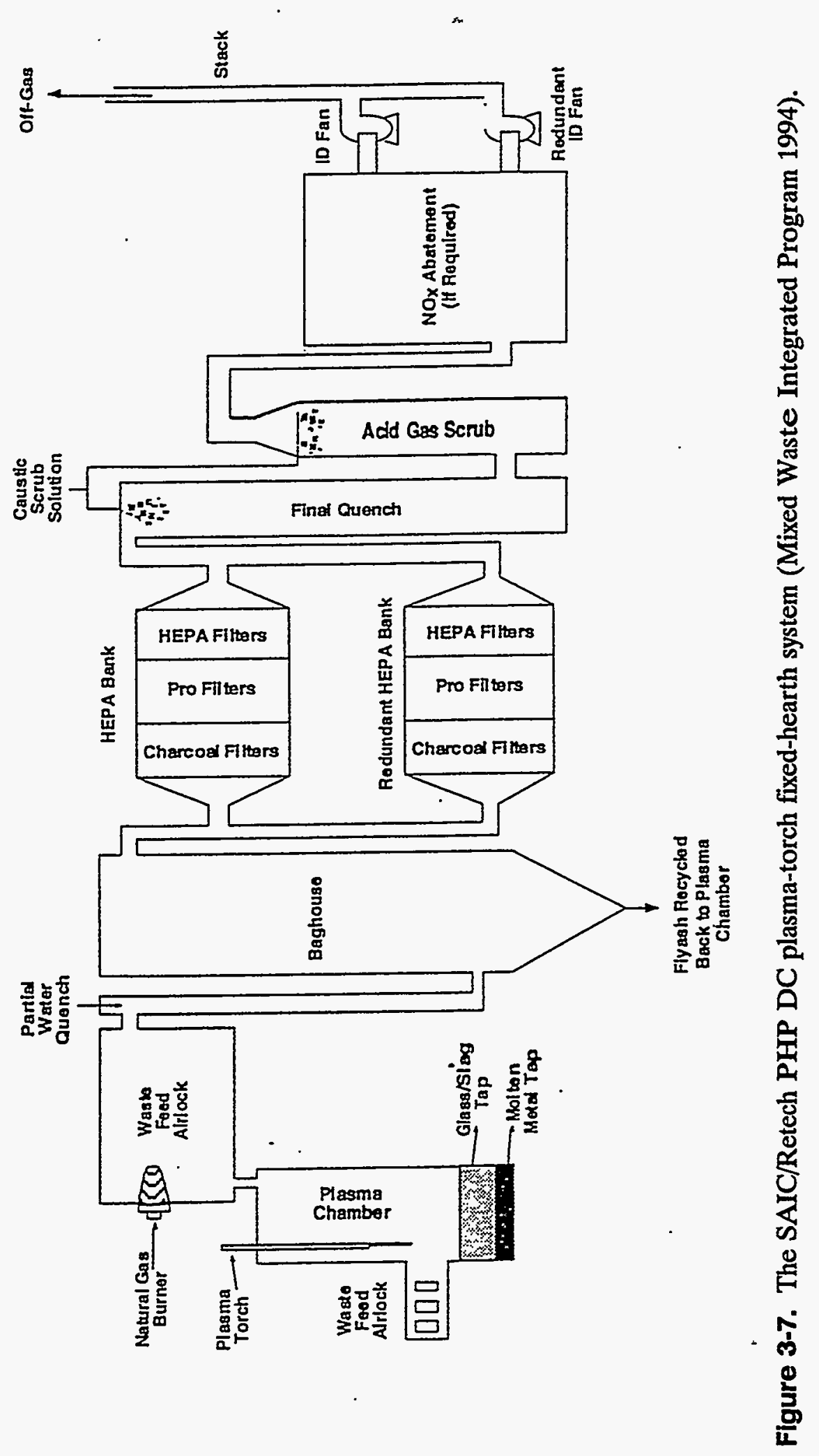




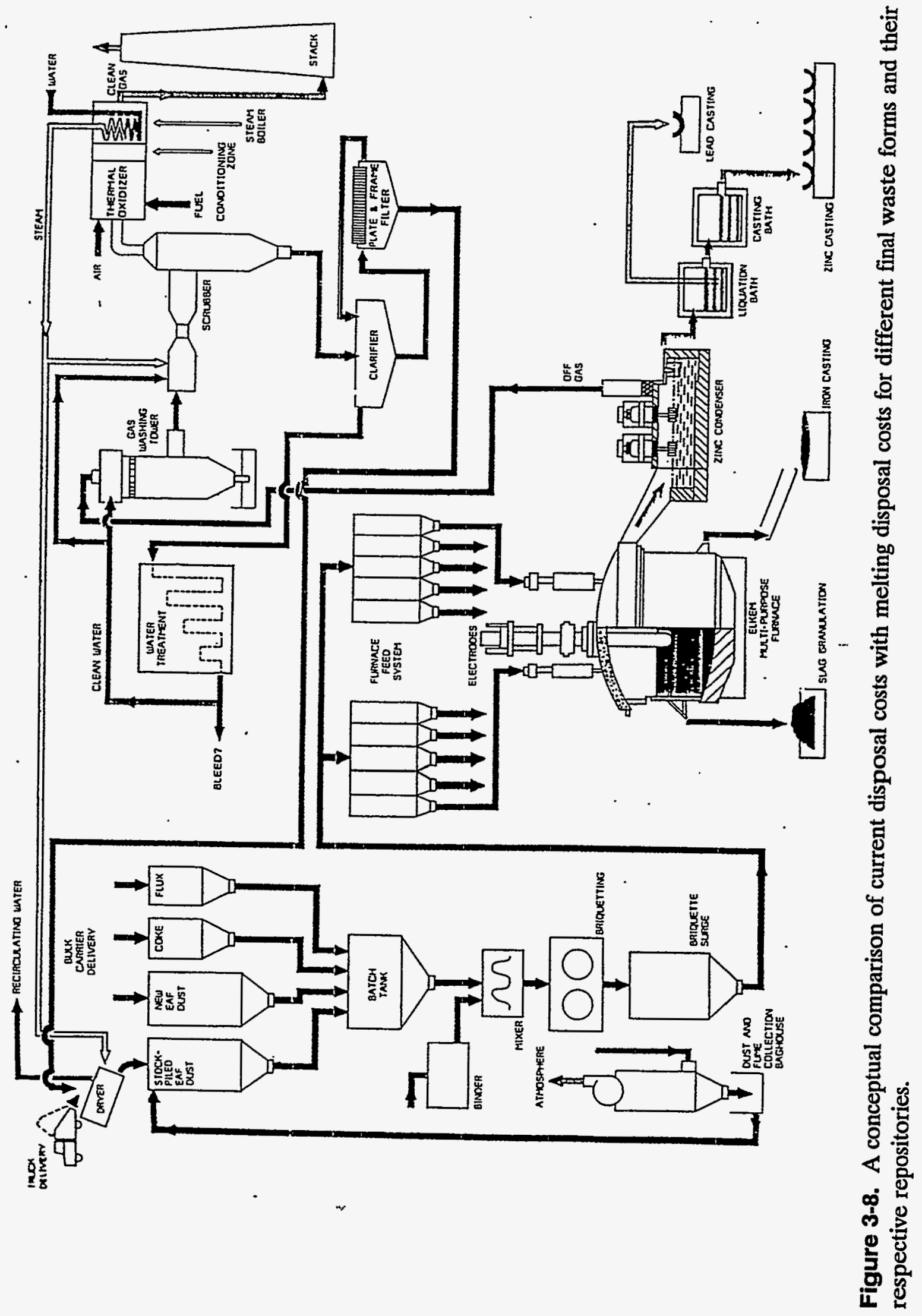


- International Milling Machine-Tetronics torch/graphite plasma melter (Figure 3-11)

- $\quad$ Pyromet-Mintek plasma-arc system (Figure 3-12)

- Ticron extended plasma-arc reduction system (Figure 3-13)

- Ausmelt Sirosmelt system with a fuel/air/oxygen lance (Figure 3-14).

The Ausmelt Sirosmelt process is not a plasma arc melter system, but is similar in providing heat directly into the melt. In contrast, the process requires a fuel, additional offgas capacity, turbulence, and two stages in two different units to accomplish the task.

For metals reclamation, additives such as coke breeze, coal, or other carbonaceous material are used to reduce the $\mathrm{Zn}, \mathrm{Pb}$, and $\mathrm{Cd}$ as well as iron and other metals. The presence of coke or graphite should, therefore, not be a problem in arc melters when the melter size is relatively small (on the order of 1-2 m). Hollow electrodes through which EAF dust is fed to the melter allows particle size ranges of 0.1 to $12 \mathrm{~mm}$.

These systems were designed to chemically reduce and volatilize from the melter large amounts of $\mathrm{Zn}, \mathrm{Pb}$, and $\mathrm{Cd}$. These relatively volatile metals are entrained in the offgas, condensed in downstream sections, and collected for recovery; therefore, some melters encourage volatilization of metal species (e.g., the Davy McKee Hi-Plas melter).

Table 3-3 lists the existing EAF dust treatment technologies that appear to be possibilities for melting DOE MLLW and TRUW materials, and also contaminated soil. Three ratings are given: Best, Better, and Questionable, based on present assumptions about the processes and the types of mixed waste to be processed. Major characteristics of the treatment systems are identified in the table, as are perceived advantages and disadvantages.

Somewhat surprising is that the ac modes are rated best in spite of recent shifts in scrap melting to more stable, efficient, and apparently superior dc melters. In this limited evaluation, best was assigned to those units that would probably incur minimum maintenance. In the Ticron melter, the electrodes are mounted through the sides at $30^{\circ}$ to the horizontal, which facilitates 


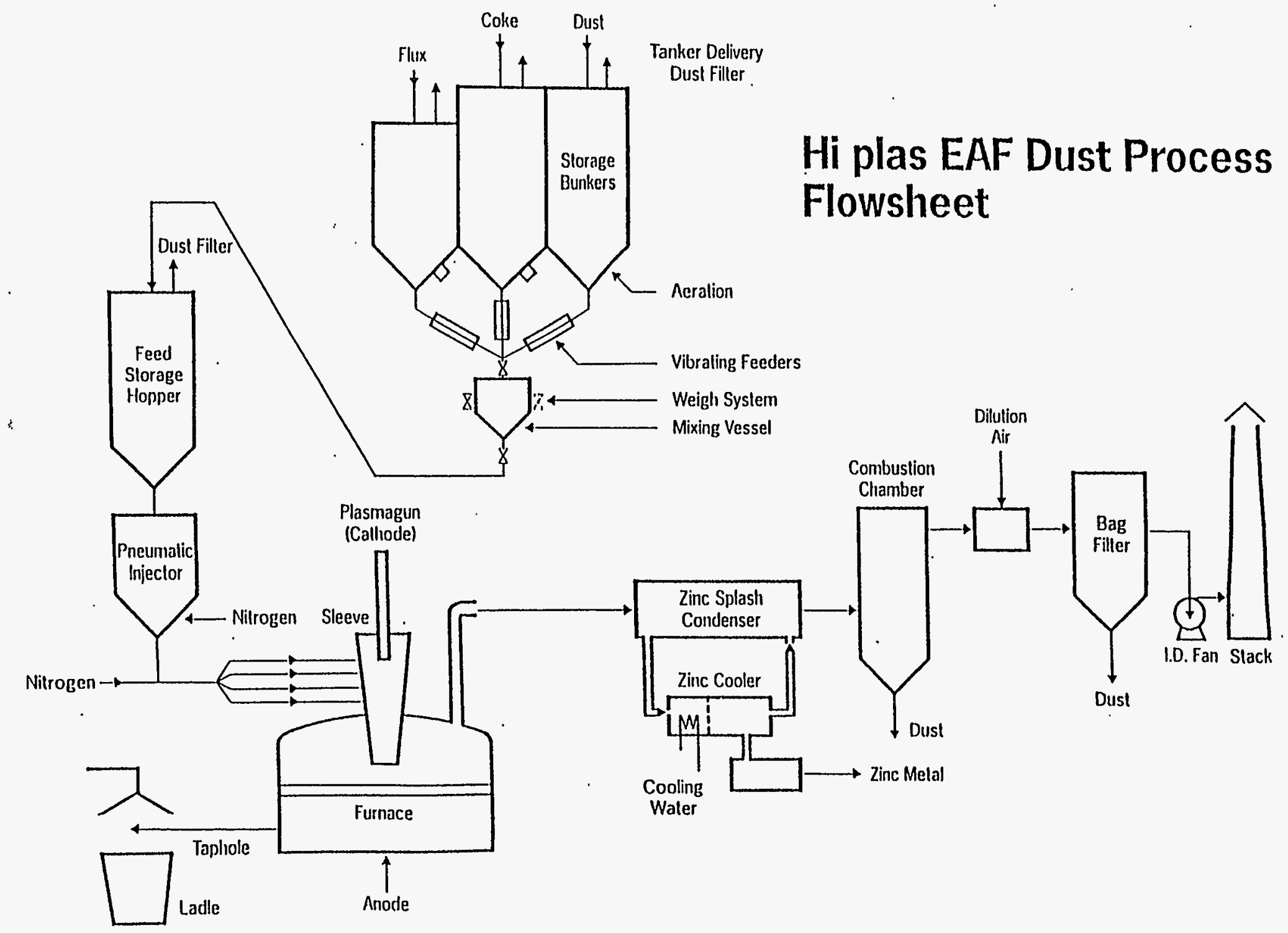

Figure 3-9. The Elkem 3-phase ac arc melter HTMR system (Bosley 1992). 


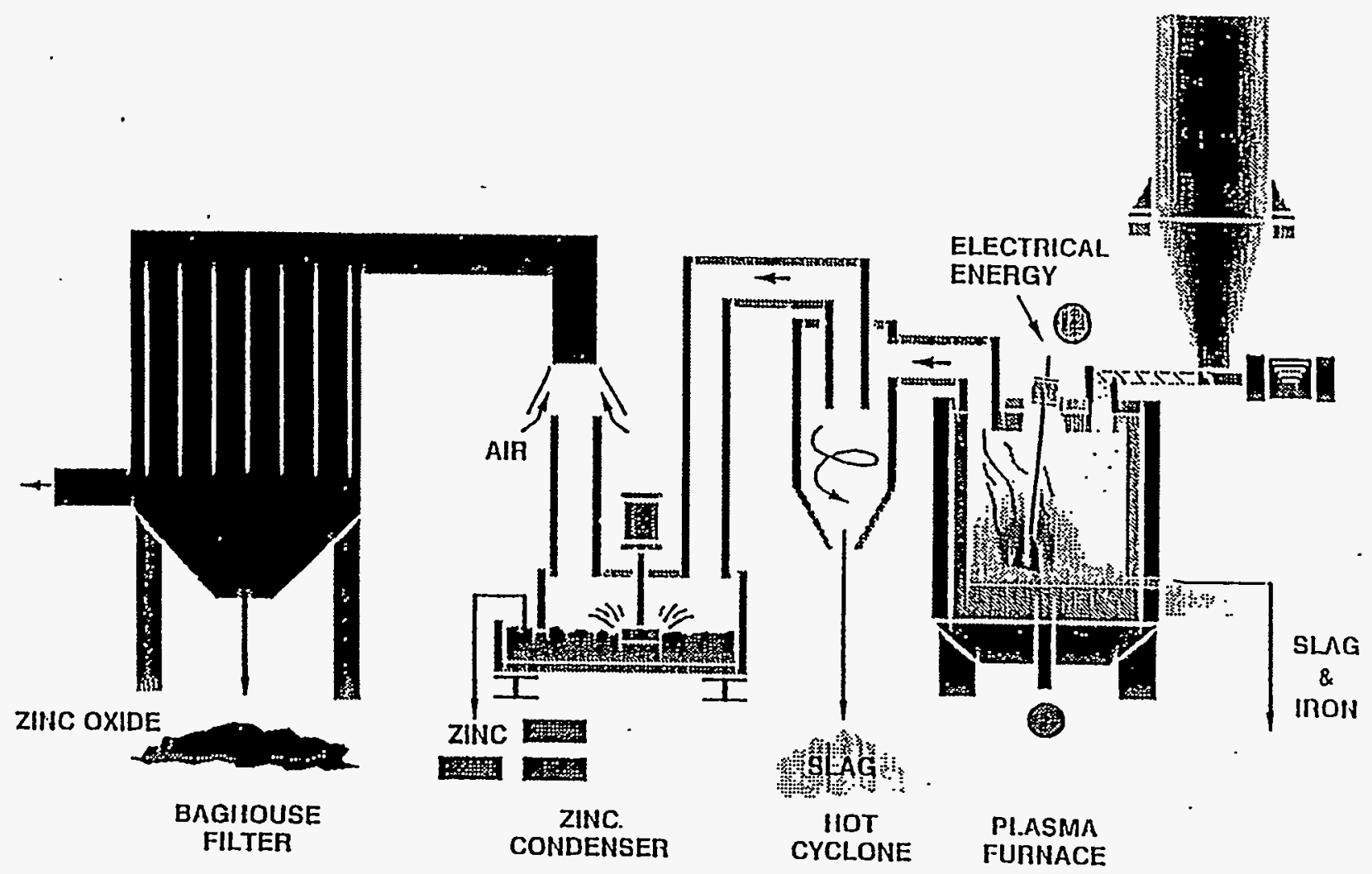

Figure 3-10. The Davy-McKee dc Hi-Plas EAF dust process flowsheet (Bosley 1992).

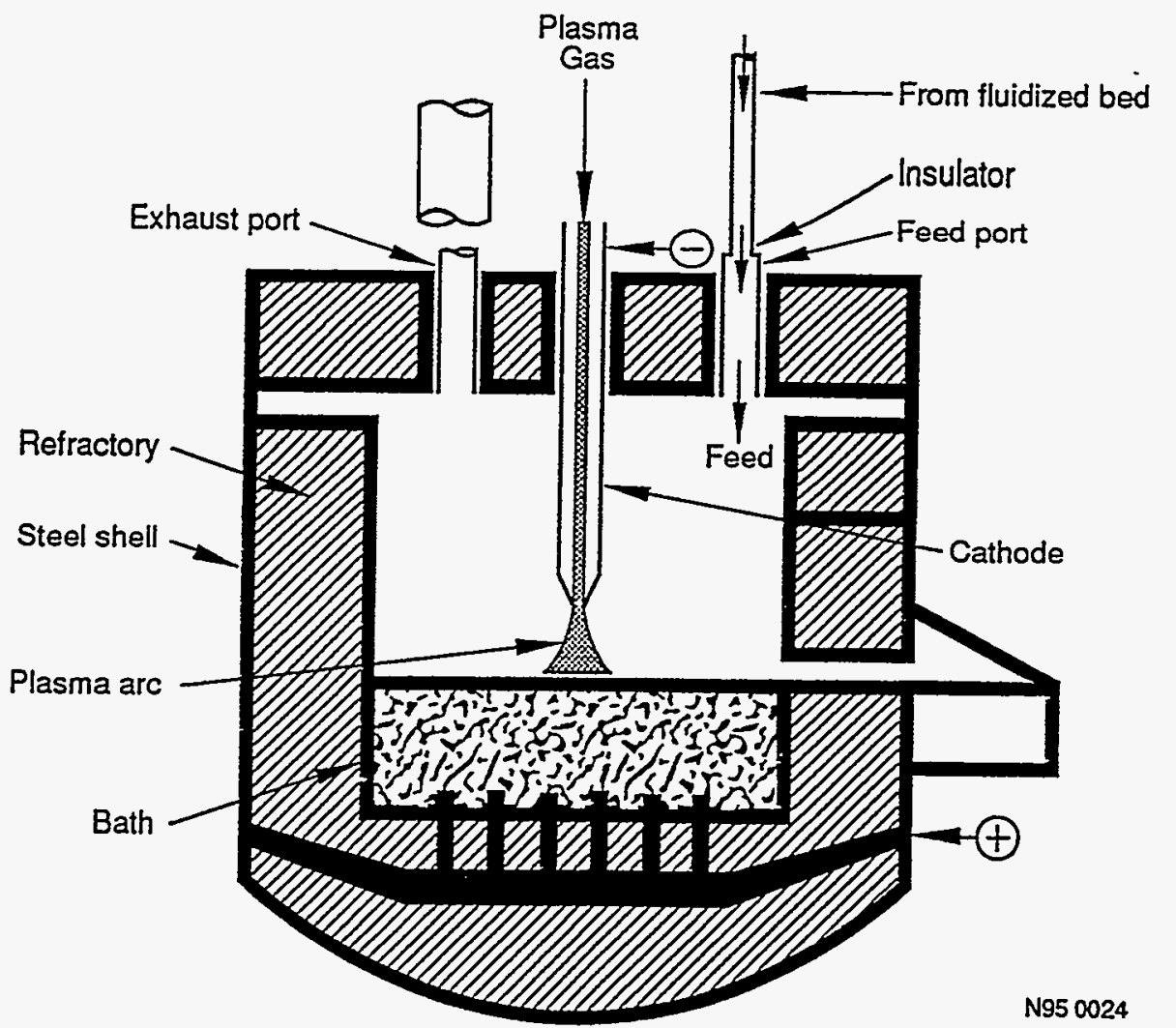

Figure 3-11. The IMS-Tetronics dc torch/graphite plasma melter system (Bosley 1992). 


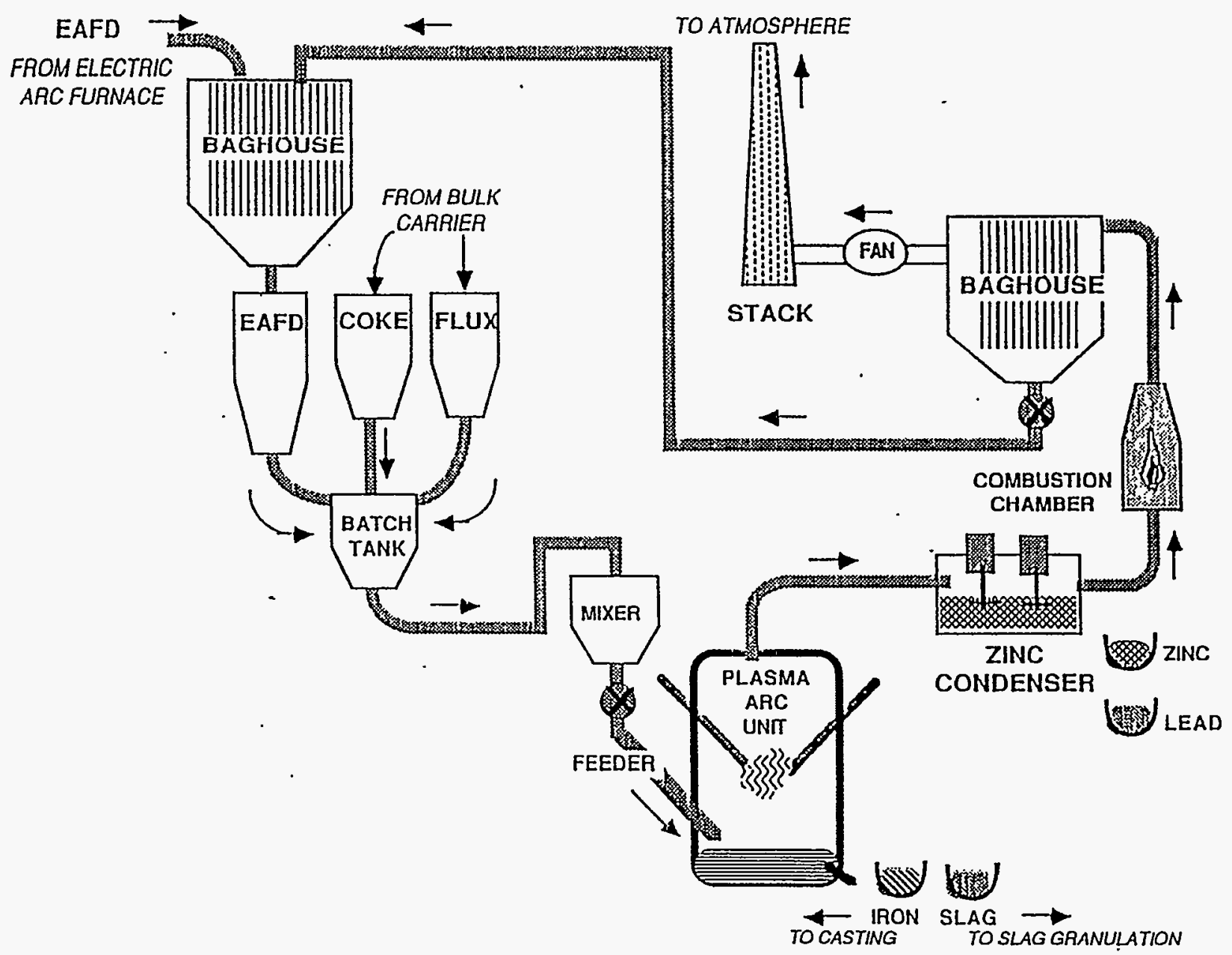

Figure 3-12. The Pyromet-Mintek dc plasma-arc melter (Bosley 1992).

starting and control. A large plasma arc is apparently generated above the melt (little Joule heating). There is a question as to the precise location of the feed, whether it is above or below the slag. It is probably difficult to maintain a cold cap of unmelted material on top of the pool of molten material.

Little information is provided about the Elkem unit, but it does have a water-cooled skull that can be used to control the diffusion of radionuclides into the refractory. The water cooling also extends refractory lifetime. Pelletizing may be necessary in the Elkem unit because of the way it feeds or transports the EAF dust. Elkem has an industrial unit operating in Illinois. The Elkem unit is similar to the USBM melter at Albany, Oregon.

The better systems are so rated because of the additional maintenance on the bottom electrodes, which need to be replaced periodically. If the melted iron is left in the bottom of the melter, the refractory corrosion is reduced. If the corrosion is substantially reduced, the number of heats are increased, maintenance is reduced, and the bottom electrode may not be a problem. The disadvantage of the bottom electrode is counteracted by the advantage of the hollow electrode feed (in the Pyromet-Mintek unit), which will tend to convect the feed down into the melt and minimize volatilization. Maybe the Pyromet unit should be in the best class. The Pyromet-Mintek unit operates with a relatively short electrode gap. 


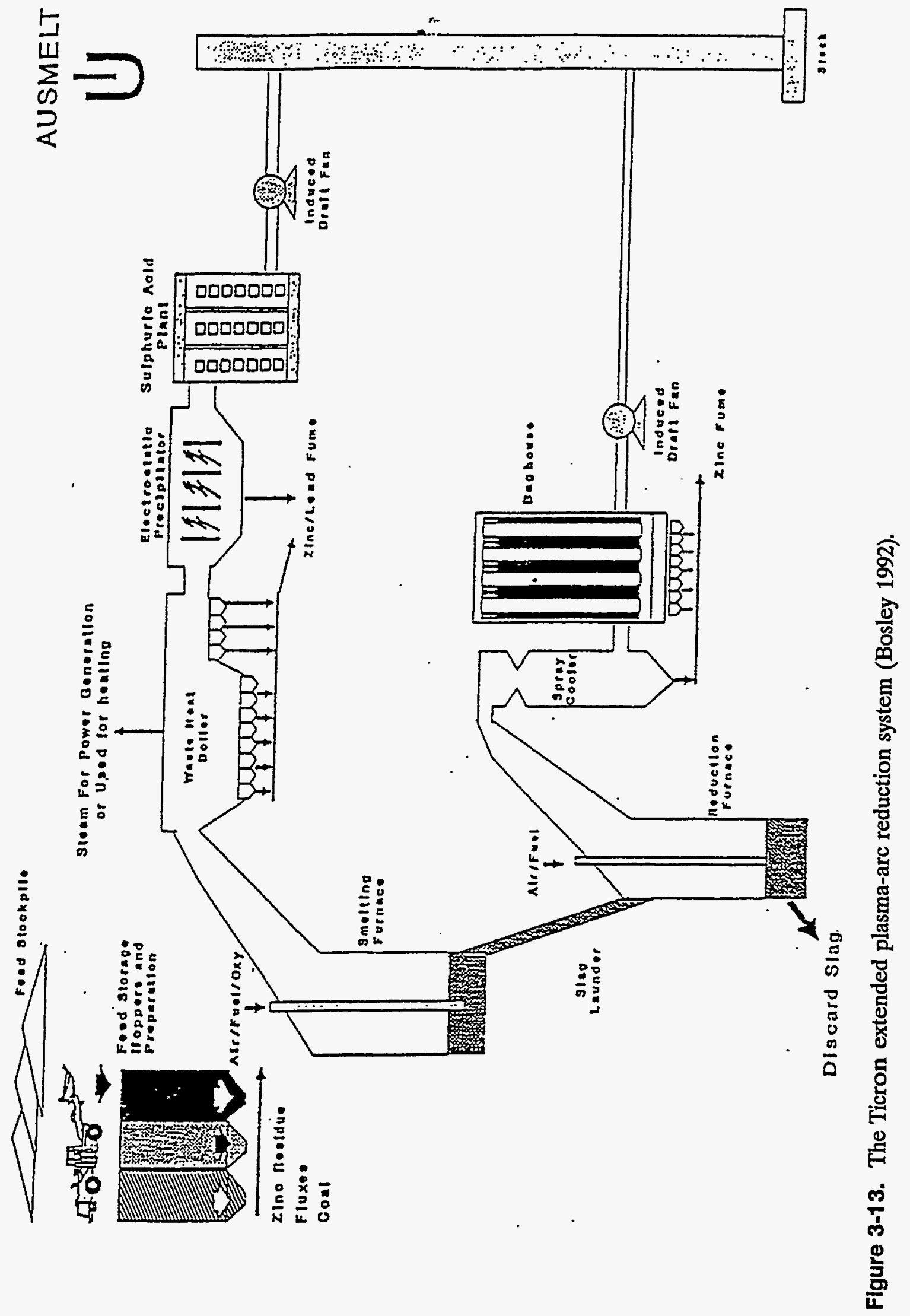




\section{CURRENT VS. MELTING DISPOSAL COST}

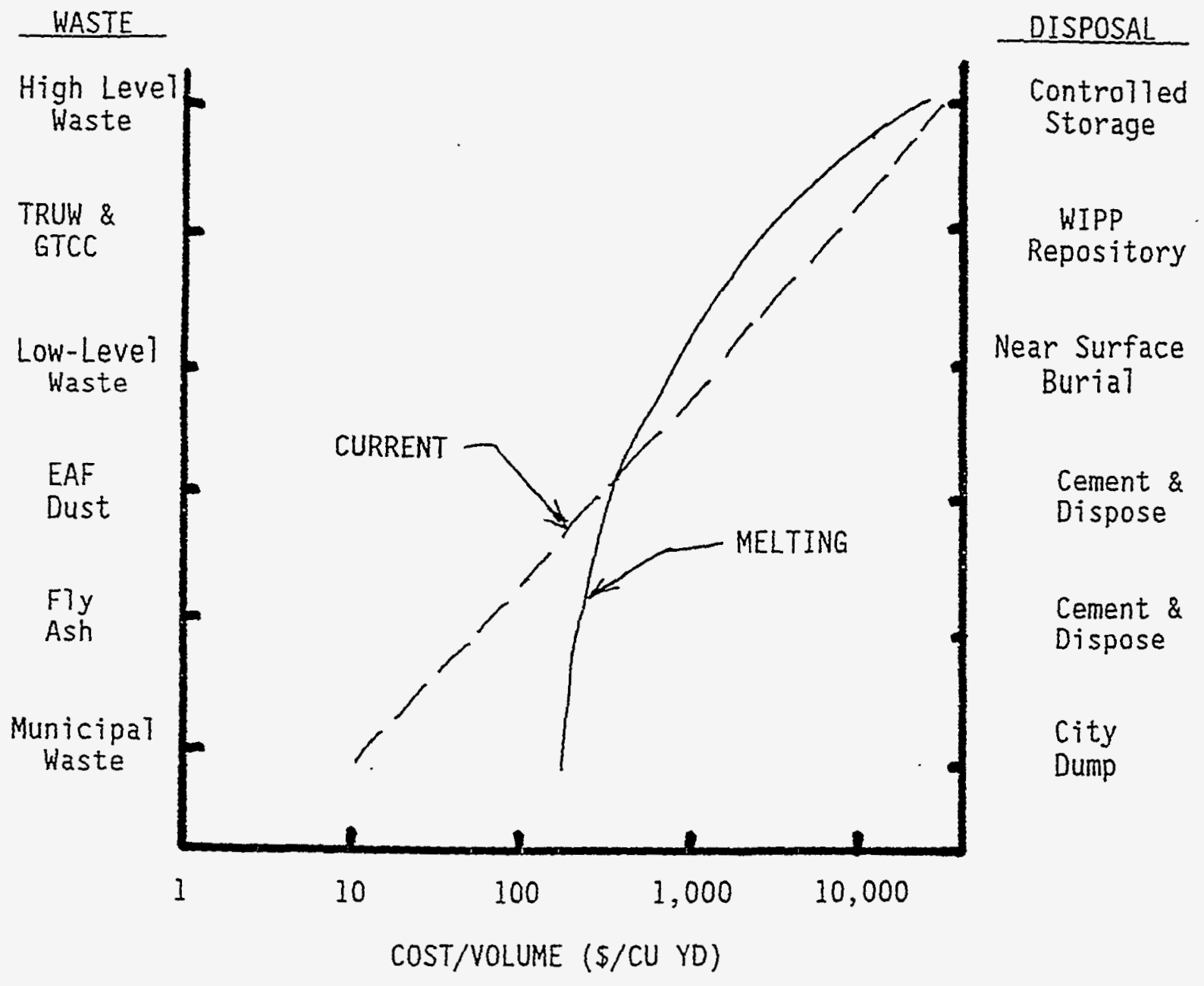

Figure 3-14. The Ausmelt Sirosmelt system with a fuel/air/oxygen lance (Bosley 1992).

The International Milling Machine-Tetronics (IMS/Tetronics) unit operates with a long arc, similar to the Retech plasma hearth torch with a long arc. IMS started with a Tetronics transferred-arc plasma torch but abandoned it after industrial installation because of maintenance problems. They were averaging only 30 hours before a water leak developed and the torch had to be serviced. After an eruption, they switched both installations to graphite electrodes, but operated them like the torch-with a long arc to get a relatively large heating footprint in the melt to encourage volatilization. Sealing problems were overcome by adding water-cooled packing gland seals at the cathode roof penetration. Roof heating problems were resolved by raising the roof $0.5 \mathrm{~m}$ and insulating it. Power consumption is about $1,080 \mathrm{kWh} / \mathrm{MT}$ of feed. Stability problems were also experienced due to the three iron anodes $\left(1 \mathrm{ft}^{2}\right.$ each) used in the bottom. Adding a layer of conducting refractory on the bottom balanced the current distribution in the three anodes and stabilized operation. IMS had two industrial systems in operation until the price of zinc dropped. 
Table 3-3. Existing EAF dust treatment technologies applicable to melting RWMC ALLW and TRUW materials.

\begin{tabular}{ccc}
\hline Technology & Advantages & Disadvantages \\
\hline
\end{tabular}

\section{Best}

1. Ticron Ecological Corp., Toronto, Canada

Extended plasma-arc reduction $1 \mathrm{t} / \mathrm{h}, 2.5-\mathrm{MW}$ unit Pilot plant in Ontario Ladle heating in Pueblo, Co

2. Elkem Technology, Pittsburgh, PA, USA

High-temperature metal recovery

$5 \mathrm{thh}$

Industrial installation in IL

\section{Better}

3. Pyromet-Mintek, Randburg, South Africa

Plasma arc melter process

$2 \mathrm{t} / \mathrm{h}, 3.2 \mathrm{MW}$

Pilot plant in South Africa

4. International Mill Service, Horsham, PA, USA

IMS/Tetronics plasma process 1-2 t/h, 1-3 MW

Industrial installations in TN, AK

Pilot plant in UK, uses plasma torch

\section{Questionable}

5. Davy Mckee Limited, UK Heckett Technology Services, USA

Hi-Plas technology

$0.4 \mathrm{t} / \mathrm{h}, 1 \mathrm{MW}$

Pilot plant in UK

6. Ausmelt Pty, Ltd, Australia Big River Minerals Corp-USA St Louis, MO Sirosmelt fuel/air lance $50 \mathrm{~kg} / \mathrm{h}$ to $50 \mathrm{MT} / \mathrm{h}$ Lab-scale in Australia and Denver

Smelter in Korea $(10 \mathrm{t} / \mathrm{h})$ 3-ph ac, graphite electrodes with hole Low argon flow through electrodes Stable, nonturbulent operation Feed at slag-metal interface under arc Large footprint on melt (1-2 m)

3-ph ac graphite electrodes Operates with water-cooled skull

dc hollow graphite cathode Feed through electrode No pelletizing or briquetting Computerized feed and control

dc hollow graphite cathode Argon flow through electrode No pelletizing required Large arc attachment (>0.5 m) Long arc and radiation ( $<=0.5 \mathrm{~m}$ ) Switched from torch to graphite to reduce maintenance and costs

DC water-cooled cathode Argon-stabilized transferred arc Quiet, nonturbulent bath Radiation to walls and roof minimized No pelletizing required Good sealing capabilities Low cathode maintenance

Good sealing

Bubbling creates mixing
Large radiation to walls Refractory cooled

Pelletixing necessary(?) (others don't)

Three separate top feed tubes

Refractory cooled(?)

Bottom pin anodes Refractory cooled(?)

Bottom pin anodes plus conducting refractory Feed through top of unit (Tubes not apparent) Long arc and radiation Refractory cooled(?)

Bottom anode

Vortex feed Nitrogen gas feed High volatilization/fuming Refractory cooled(?)

Fuel/air/oxygen fired Additional offgas flow Bubbling creates entrainment Requires two stages:

1) Gas flushing stage

2) Reducing stage 
Systems were rated Questionable when there was a high probability of volatilization, fume, and dust carryover, which would carry the TRU along with the volatiles, probably causing the offgas residue to be classified as TRUW with the higher disposal costs and system maintenance. The Davy McKee Hi-Plas system has a number of advantages over the other melters, but the potential carryover of TRU may nullify the advantages, as discussed at an informal Buried Waste Integrated Demonstration meeting (Mohiuddin and Schneider 1994). Both of these last systems are offgas intensive and require larger components, which is another detriment.

In conclusion, the best and better are pretty close. There are some similarities among present arc melter demonstrations:

1. The USBM 3-ph ac melter is similar to the Elkem melter.

2. The Retech dc plasma hearth melter is similar to the IMS/Tetronics melter with the plasma torch.

3. The Retech dc plasma centrifugal reactor at Butte is similar to the $\mathrm{MMS} /$ Tetronics (fixed) melter with the plasma torch.

4. The Electro-Pyrolysis Inc. (EPI) dc melter at MIT is similar to the Pyromet-Mintek melter, but without feeding through the electrode and with a graphite refractory shell.

The operational successes and lessons learned with hazardous EAF dust systems provide a good stepping stone for commercial plasma arc melter technology to be applied to radioactive waste. 


\section{WASTE STREAMS, SLAG CHARACTERISTICS, AND FINAL WASTE FORMS}

The mixed waste streams considered for treatment in the preliminary treatment system design vary widely in chemical composition and physical makeup. There are over 100 different streams coded for reference in data bases. These were grouped according to chemistry, heterogeneity, and compositions. Slag compositions that result from the different feed mixtures can vary widely from each other and from the input waste compositions due to thermal decomposition, volatilization, oxidation, dissolution, and separation of many of the different waste components. These slag compositions have been determined experimentally and predicted using thermodynamic models. Additives such as soil have been included in some cases as a buffer to adjust the slag chemistry. There has been much work done to characterize the waste streams, evaluate the properties of the slag with and without soil additions, and describe some of the final waste form options (Reimann 1992; Eddy et al. 1992; Grandy, Eddy, and Anderson 1993a and 1993b; and Reimann and Kong 1993).

Significant variations in the composition of a waste stream may produce an unsuitable final waste form (FWF) if the variations result in a FWF that has high leachability, low durability, or other limitations.

\subsection{Input Waste Streams}

The inventory of ALLW/TRUW in the Subsurface Disposal Area (SDA), the Transuranic Storage Area (TSA), and in Pit 9 at the INEL Radioactive Waste Management Complex (RWMC) is shown in Table 4-1 (Arrenholz and Knight 1990, Virgil 1990). Each major category has been given a series code for simplicity in Figure 4-1. The figure illustrates the relative magnitudes of each major waste category. Additional information on the hydrated metal oxides (H1 and $\mathrm{H} 2$ ), calcium-silicated organics (S), Portland-cemented organics $(\mathrm{P})$, alkali nitrate $(\mathrm{N})$, and metallic (M) series is contained in Table 4-2. Table 4-3 gives an estimated species composition of some of the substances in the various waste streams. Table 4-4 presents expected treatment challenges and potential solutions of several of the waste components.

\subsection{Slag Melt Compositions and Properties}

The slag melt compositions for the major waste categories and for the "average" waste mixture have been determined experimentally and in thermodynamic models. Previous material studies and FWF experiments for wastes stored at the RWMC have resulted in three separate waste compositions (Flinn 1981a). These were called A-, B- and C-series slags. The average waste composition, determined by theoretically mixing all of the ALLW/TRUW at RWMC, would form an A-series slag with the compositions shown in Table 4-5. The A-series compositions are in the range of a ferro-alumino-silicate, otherwise called an iron-enriched basalt (IEB), which has many desirable characteristics as a FWF. Figure 4-2 is a plot of the data in Table 4-5. The plot shows the makeup of the processed waste as a function of the wt\% soil that has been added. The change in any slag constituent can be easily followed as more soil is added to the melt. Soil addition is a very effective way to increase the silica content of the slag since there is contaminated soil that requires treatment. 
Table 4-1. Mass and volumes per category in selected areas of the RWMC (Grandy, Eddy, and Anderson 1993).

\begin{tabular}{|c|c|c|c|c|c|c|}
\hline \multirow[b]{2}{*}{ Category } & \multicolumn{2}{|c|}{ Pit 9} & \multicolumn{2}{|c|}{$\mathrm{SDA}^{\mathrm{a}}$} & \multicolumn{2}{|c|}{ TSA } \\
\hline & $\begin{array}{l}\text { Mass } \\
(\mathrm{kg})\end{array}$ & $\begin{array}{l}\text { Vol } \\
\left(\mathrm{m}^{3}\right)\end{array}$ & $\begin{array}{l}\text { Mass } \\
(\mathrm{kg})\end{array}$ & $\begin{array}{l}\text { Vol } \\
\left(\mathrm{m}^{3}\right)\end{array}$ & $\begin{array}{l}\text { Mass } \\
(\mathrm{kg})\end{array}$ & $\begin{array}{l}\text { Vol } \\
\left(\mathrm{m}^{3}\right)\end{array}$ \\
\hline Organics/Ca silicates & 746,776 & 249 & $1,911,100$ & 2,480 & $1,617,000$ & 1,422 \\
\hline Cemented organics & 16,700 & 16 & 493,800 & 640 & $2,164,899$ & 1,832 \\
\hline $\mathrm{Na} / \mathrm{K}$ nitrates & 252,700 & 114 & $1,737,300$ & 2,250 & 11,400 & 14 \\
\hline Hydrated oxides & 65,700 & 61 & $5,001,700$ & 6,480 & $5,730,900$ & 4,811 \\
\hline Acids and bases & 11,700 & 5 & $(54,500)^{b}$ & (57) & $\mathbf{0}$ & 0 \\
\hline Bricks, concrete & 87,500 & 83 & $3,025,320$ & 6,120 & $4,485,763$ & 12,200 \\
\hline HVPM/reactive metal & 10,980 & 4 & 279,630 & 660 & 163,000 & 401 \\
\hline Other metal & 658,600 & 428 & $6,207,800$ & 5,660 & $5,868,000$ & 12,882 \\
\hline Miscellaneous combustible & 20,200 & 71 & $5,620,500$ & 27,660 & $5,277,700$ & 15,804 \\
\hline $\begin{array}{l}\text { Unclassified/remote } \\
\text { handling }\end{array}$ & 0 & 0 & 26,870 & 70 & $3,474,300$ & 5,841 \\
\hline TRU & 17 & 0.0008 & 381 & 0.028 & 710 & 0.053 \\
\hline LLW & 11,700 & 1 & 203,320 & 15 & 23,434 & 2 \\
\hline Total & $1,882,573$ & 1,032 & $24,562,221$ & 52,092 & $28,817,106$ & 55,209 \\
\hline
\end{tabular}

a. Estimates made on information from Arrenholz and Knight (1990) and Vigil (1990).

b. Very rough estimate from Vigil (1990). 


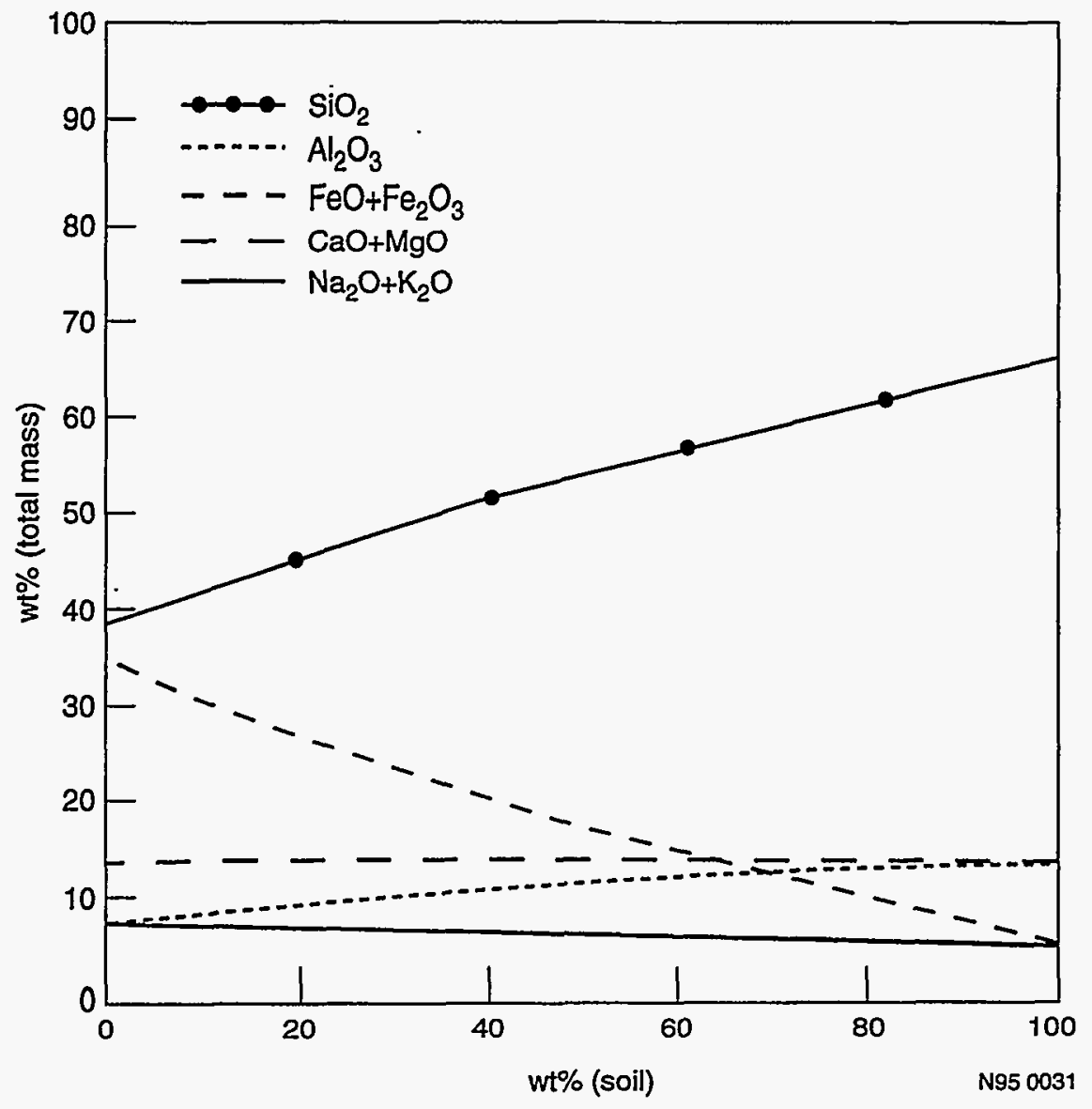

Figure 4-1. Relative concentrations of the major waste streams in the TSA, SDA and Pit 9 of the RWMC.

The percentage of soil refers to the wt\% of oxides from the added soil in the slag, after organics, halogens, and other combustibles or volatiles have been removed from the waste-soil mixture through thermal desorption, volatilization, oxidation, and separation reactions in the melting process. It is not the wt\% of soil added to the mass of original waste. This method is used for consistency in defining desirable slag compositions in spite of variable input stream compositions.

To determine the final waste form composition after waste processing in a melter, some assumptions must be made. A general assumption is that all moisture, water of hydration, organics, carbonates, nitrates, sulfates, and chlorides will decompose, volatilize, or oxidize and produce gases, including $\mathrm{H}_{2} \mathrm{O}, \mathrm{CO}, \mathrm{CO}_{2}, \mathrm{C}_{\mathrm{m}} \mathrm{H}_{\mathrm{n}}, \mathrm{NO}_{x} \mathrm{~N}_{2}, \mathrm{HCl}$, and $\mathrm{SO}_{2}$. The metals will oxidize and dissolve in the slag or else form a separate metal phase. Some metals that have higher vapor pressures will tend to volatilize and require collection in the offgas system. The degree of volatilization depends on the specific metal, slag and plenum temperatures, interactions with other species such as chlorine, and melter design and operation.

It is assumed that the waste packaging material will be processed along with original waste and must be included as part of the waste stream. Waste packaging and handling has sometimes included mixing extra materials with the waste to produce something easer to handle, such as the solid material produced by adding calcium silicates to liquid organics. Additional materials such as 
Table 4-2. Waste material chemical compositions.

\begin{tabular}{|c|c|c|c|}
\hline CC/name & RFP & $\begin{array}{c}\text { Chemical composition } \\
\text { (wt\%) }\end{array}$ & Designator \\
\hline $\begin{array}{l}\text { 1/first stage } \\
\text { sludge }\end{array}$ & 741 & $\begin{array}{l}\mathrm{H}_{2} \mathrm{O}(60 \%), \mathrm{SiO}_{2}(14 \%), \mathrm{Al}_{2} \mathrm{O}_{3}(3 \%) \\
\mathrm{FeO}(0 \%), \mathrm{Fe}_{2} \mathrm{O}_{3}(3 \%), \mathrm{MgO}(2 \%), \\
\mathrm{CaO}(2 \%), \mathrm{Na}_{2} \mathrm{O}(11 \%), \mathrm{K}_{2} \mathrm{O}(2 \%) \\
\text { other (3\%) }\end{array}$ & $\begin{array}{l}\text { (H1)-Hydrated metal } \\
\text { oxides }\end{array}$ \\
\hline $\begin{array}{l}2 / \text { second stage } \\
\text { sludge }\end{array}$ & 742 & $\begin{array}{l}\mathrm{H}_{2} \mathrm{O}(60 \%), \mathrm{SiO}_{2}(19 \%), \mathrm{Al}_{2} \mathrm{O}_{3}(2 \%) \\
\mathrm{FeO}(0 \%), \mathrm{Fe}_{2} \mathrm{O}_{3}(2 \%), \mathrm{MgO}(4 \%), \\
\mathrm{CaO}(10 \%), \mathrm{Na}_{2} \mathrm{O}(2 \%), \mathrm{K}_{2} \mathrm{O}(1 \%), \\
\text { other }(0 \%)\end{array}$ & $\begin{array}{l}\text { (H2)-Hydrated metal } \\
\text { oxides }\end{array}$ \\
\hline $\begin{array}{l}\text { 3/organic } \\
\text { setups }\end{array}$ & 743 & $\begin{array}{l}\text { Texaco regal oil (28\%), } \mathrm{CCl}_{4}(19 \%) \text {, } \\
\mathrm{Cl}_{2} \mathrm{CHCH}_{2} \mathrm{Cl}(10 \%), \text { misc. oils (hydraulic, } \\
\text { gearbox, freon,etc.) }(43 \%)\end{array}$ & $\begin{array}{l}(\mathrm{S})-\mathrm{CaSiO}_{3} \text { solidified } \\
\text { organic waste }\end{array}$ \\
\hline 4/special setups & 744 & $\begin{array}{l}\text { Alcohols, organic acids and } \\
\text { chelating agents (100\%) } \\
\text { (specific makeup unknown) }\end{array}$ & $\begin{array}{l}\text { (P)-Portland cemented } \\
\text { organics }\end{array}$ \\
\hline $\begin{array}{l}\text { 5/evaporator } \\
\text { salts }\end{array}$ & 745 & $\begin{array}{l}\mathrm{NaNO}_{3}(60 \%), \mathrm{KNO}_{3}(30 \%) \text {, misc. } \\
(10 \%)\end{array}$ & (N)-Nitrates \\
\hline $\begin{array}{l}\text { 480/unleached } \\
\text { light non- } \\
\text { special source } \\
\text { metal }\end{array}$ & UNK & $\begin{array}{l}\mathrm{Fe}(62 \%) \text {, other ( } \mathrm{Cu}, \mathrm{Al}, \mathrm{Cr} \text {, etc) }(26 \%) \\
\mathrm{SiO}_{2}(3 \%), \mathrm{Al}_{2} \mathrm{O}_{3}(2 \%), \mathrm{CaO}(2 \%) \\
\text { other combustible (5\%) }\end{array}$ & (M)-Metals \\
\hline
\end{tabular}

vermiculite, oil dry, or portland cement were usually added to absorb any liquid residues that might accumulate in a waste container. The waste is stored in either 55-gallon drums or boxes. The boxes are made of plywood and coated with fiberglass reinforced polyester (FRP). Since they are primarily organic, they will not significantly affect the slag composition since the organic material will volatilize and oxidize out of the melt. The steel from drums adds to the iron oxide content of the slag.

Figures 4-3 through 4-8 show the calculated final slag compositions for the H1, H2, S, P, N, and $M$ waste series. The compositions vary according to the soil content in the slag. In the same manner as the A-series slags, H1-0, M-0, etc., are the slag compositions with no soil added. The value for the added soil is based on the wt\% of oxides from the soil in the slag after moisture, organics, and other volatile materials are decomposed, volatilized, and oxidized. The final composition of each type of waste plus the amount of soil added can be examined to see if it falls within the limits of iron enriched basalt (Kong 1991). 
Table 4-3. Composition of input waste streams and soil considered (mass \%).

\begin{tabular}{|c|c|c|c|c|c|c|c|c|}
\hline Species & G1 & M1 & C.5 & $\mathbf{P}$ & $\underline{\mathbf{s}}$ & HD1 & Nom-60 & Soil \\
\hline Al & 0.08 & 9.75 & - & - & - & - & 0.75 & - \\
\hline $\mathrm{Al}_{2} \mathrm{O}_{3}$ & 4.39 & 1.6 & 5.87 & 3.76 & 0.28 & 2.51 & 6.55 & 10.32 \\
\hline $\mathrm{BaO}$ & - & - & 1.10 & - & - & - & 0.006 & - \\
\hline C & 3.87 & 8.38 & 16.71 & 2.85 & 24.15 & 0.97 & 8.65 & - \\
\hline $\mathrm{CaCO}_{3}$ & - & - & - & - & - & - & 7.61 & 11.37 \\
\hline $\mathrm{CaO}$ & 3.61 & 1.11 & 1.57 & 25.38 & 9.94 & 7.09 & 0.99 & 1.71 \\
\hline $\mathrm{Cl}_{2}$ & 0.34 & 0.27 & 0.37 & 0.26 & 34.7 & 0.07 & 1.95 & - \\
\hline $\mathrm{CO}_{2}$ & - & 0.05 & 0.06 & 0.39 & - & 0.04 & - & - \\
\hline $\mathrm{Cr}^{-}$ & 4.04 & 6.13 & 0.28 & 1.50 & 1.98 & 1.96 & 0.82 & - \\
\hline $\mathrm{Cr}_{2} \mathrm{O}_{3}$ & - & - & - & 0.01 & - & 0.02 & 0.02 & - \\
\hline $\mathrm{Cu}$ & 0.03 & 3.25 & - & - & - & - & 0.23 & - \\
\hline $\mathrm{CuO}$ & - & - & - & 0.04 & - & 0.06 & 0.003 & - \\
\hline $\mathbf{F e}$ & 15.43 & 47.99 & 1.05 & 5.69 & 7.49 & 7.42 & 12.37 & - \\
\hline $\mathrm{Fe}_{2} \mathrm{O}_{3}$ & 0.31 & 1.13 & 0.20 & 1.75 & 1.40 & 1.81 & 0.371 & - \\
\hline $\mathrm{Fe}_{3} \mathrm{O}_{4}$ & - & - & - & - & - & - & 2.48 & 3.52 \\
\hline $\mathbf{F e O}$ & 0.12 & 0.42 & 0.10 & 0.55 & 0.69 & 0.37 & - & - \\
\hline $\mathrm{Ga}_{2} \mathrm{O}_{3}$ & - & - & - & 0.57 & - & 0.93 & - & - \\
\hline $\mathrm{H}_{2}$ & 0.58 & 1.03 & 2.03 & 0.44 & 3.31 & 0.14 & 1.34 & - \\
\hline $\mathrm{H}_{2} \mathrm{O}$ & 0.18 & 1.52 & 5.56 & 32.28 & 0.07 & 50.07 & 9.21 & 15.00 \\
\hline $\mathrm{K}_{2} \mathrm{O}$ & 0.01 & 0.01 & 0.64 & 0.83 & 0.15 & 1.36 & 1.69 & 2.32 \\
\hline MgO & 0.27 & 1.42 & 6.06 & 2.51 & 0.13 & 2.74 & 1.98 & 1.92 \\
\hline $\mathbf{N}_{2}$ & 0.01 & - & - & - & - & - & 0.20 & - \\
\hline $\mathrm{Na}_{2} \mathrm{O}$ & 14.01 & 0.82 & 4.51 & 3.42 & 0.01 & 5.63 & 0.82 & 1.36 \\
\hline $\mathbf{N i}$ & 1.92 & 3.4 & 0.13 & 0.71 & 0.94 & 0.93 & 0.37 & - \\
\hline $\mathbf{O}_{2}$ & 0.19 & 4.21 & 8.08 & 0.08 & 0.07 & 0.15 & 3.78 & - \\
\hline $\mathbf{P b}$ & - & 0.93 & - & - & - & - & 0.08 & - \\
\hline $\mathrm{PbO}$ & - & - & - & 0.10 & - & 0.16 & 0.002 & - \\
\hline $\mathrm{SiO}_{2}$ & 50.58 & 5.18 & 44.98 & 16.21 & 14.69 & 14.91 & 36.13 & 52.00 \\
\hline Sn & - & 0.32 & - & - & - & - & - & - \\
\hline $\mathrm{SO}_{3}$ & - & 0.03 & 0.03 & 0.62 & - & 0.07 & 0.01 & - \\
\hline $\mathrm{TiO}_{2}$ & 0.01 & 0.01 & 0.01 & 0.04 & 0.02 & 0.07 & 0.25 & 0.48 \\
\hline $\mathbf{Z n}$ & - & 0.98 & - & - & - & - & - & - \\
\hline $\mathrm{ZnO}$ & - & 0.01 & 0.63 & - & - & - & 0.006 & - \\
\hline Other & - & - & - & - & - & - & 1.73 & - \\
\hline
\end{tabular}

Note: This tabulation is not meant to represent the actual chemical composition of these waste streams, but it was used in modeling calculating so all elements estimated to be in the waste were included. The actual presence in the waste of species such a pure $\mathrm{C}, \mathrm{Cl}_{2}, \mathrm{H}_{2}$ and $\mathrm{N}_{2}$ is not implied. 
Table 4-4. Input waste stream materials, potential treatment issues, and potential resolutions.

\begin{tabular}{|c|c|c|}
\hline Input waste material & Treatment issues & Potential resolutions \\
\hline $\mathrm{Na}, \mathrm{NaK}, \mathrm{Mg}, \mathrm{Li}$ & Reactivity & Dilution in soil and oxide/dissolve in slag \\
\hline $\mathrm{Pb}, \mathrm{Zn}$ & Volatility & Oxidize/collect in slag or in offgas system \\
\hline $\mathrm{Hg} / \mathrm{Li}$ batteries, $\mathrm{Hg}$ & Reactivity, pollutant & Dilution in soil, collect in offgas system \\
\hline $\operatorname{TRU}(\mathrm{Pu}, \mathrm{Am})$ & $\alpha$-particles & Detect to limit exposure, oxidize/dissolve into slag \\
\hline $\begin{array}{l}\text { LLW (U, MFP, } \\
\text { MAP) }\end{array}$ & $\beta, \gamma$-radiation & Detect to limit exposure, oxidize/dissolve into slag \\
\hline Cs-137, etc. & $\begin{array}{l}\beta, \gamma \text {-radiation, } \\
\text { volatility }\end{array}$ & $\begin{array}{l}\text { Detect to limit exposure, oxidize/dissolve oxides } \\
\text { into slag, collect in offgas }\end{array}$ \\
\hline $\begin{array}{l}\text { Hydrated oxide } \\
\text { sludge }\end{array}$ & Hydrate eruption & Dilute with soil and dissolve in slag \\
\hline $\mathrm{Na} / \mathrm{K}$ nitrate sludge & High-T reactivity & $\begin{array}{l}\text { Low-T roast to get oxides, dissolve oxides in slag, } \\
\mathrm{NO}_{\mathrm{x}} \text { processed in offgas }\end{array}$ \\
\hline $\begin{array}{l}\text { Machinery, metals, } \\
\text { drums }\end{array}$ & None & $\begin{array}{l}\text { Oxidize and dissolve in slag, or tap melt and } \\
\text { package }\end{array}$ \\
\hline $\begin{array}{l}\text { Brick, concrete, } \\
\text { asbestos }\end{array}$ & None & Melt and dissolve inerts in slag \\
\hline $\mathrm{NaOH}$ & Reactivity & Dilute in soil, oxidize and dissolve inerts in slag \\
\hline Acids $(\mathrm{HCl}, \mathrm{HF})$ & Reactivity. & Dilute in soil, oxidize and dissolve inerts in slag \\
\hline Cemented organics & High-T eruption & Crush, incinerate, and dissolve inerts in slag \\
\hline $\begin{array}{l}\text { Miscellaneous } \\
\text { organics }\end{array}$ & Toxic, explosions & Process w/wo soil, incinerate, dissolve inerts in slag \\
\hline $\begin{array}{l}\text { Organics in } \mathrm{Ca} \\
\text { silicate }\end{array}$ & Proper oxidation & $\begin{array}{l}\text { Rotary kiln pyrolysis/incineration, oxidize in } \\
\text { afterburner, dissolve inerts in slag }\end{array}$ \\
\hline
\end{tabular}

Table 4-5. Average slag composition from A waste plus soil.

\begin{tabular}{lccccccccc}
\hline & $\mathrm{SiO}_{2}$ & $\mathrm{Al}_{2} \mathrm{O}_{3}$ & $\mathrm{Fe}_{2} \mathrm{O}_{3}$ & $\mathrm{CaO}$ & $\mathrm{MgO}$ & $\mathrm{Na}_{2} \mathrm{O}$ & $\mathrm{K}_{2} \mathrm{O}$ & $\mathrm{TiO}_{2}$ & $\mathrm{Misc}$ \\
\hline $\mathrm{A}-0$ & 38.0 & 7.4 & 34.5 & 8.3 & 4.6 & 4.8 & 2.4 & 0.0 & 0.0 \\
$\mathrm{~A}-20$ & 45.1 & 9.0 & 26.4 & 9.1 & 4.0 & 3.9 & 2.5 & 0.0 & 0.0 \\
$\mathrm{~A}-40$ & 51.0 & 10.3 & 19.6 & 9.7 & 3.5 & 3.2 & 2.6 & 0.0 & 0.0 \\
$\mathrm{~A}-60$ & 56.0 & 11.4 & 13.9 & 10.3 & 3.1 & 2.6 & 2.7 & 0.0 & 0.0 \\
$\mathrm{~A}-80$ & 60.6 & 12.1 & 9.5 & 10.0 & 2.8 & 2.2 & 2.8 & 0.0 & 0.0 \\
$\mathrm{~A}-100$ & 65.4 & 13.0 & 4.5 & 10.2 & 2.4 & 1.7 & 2.9 & 0.6 & 0.0 \\
\hline
\end{tabular}

Notes: 1. A-0 represents stag produced from oxides of average (A) waste components with $0 \%$ soil oxide components. A-100 represents a slag that is actually $100 \%$ oxides of soil, with no waste. The intermediate values $A-20,40,60$, and 80 represent that weight percent of soil oxides in the resultant slag. 


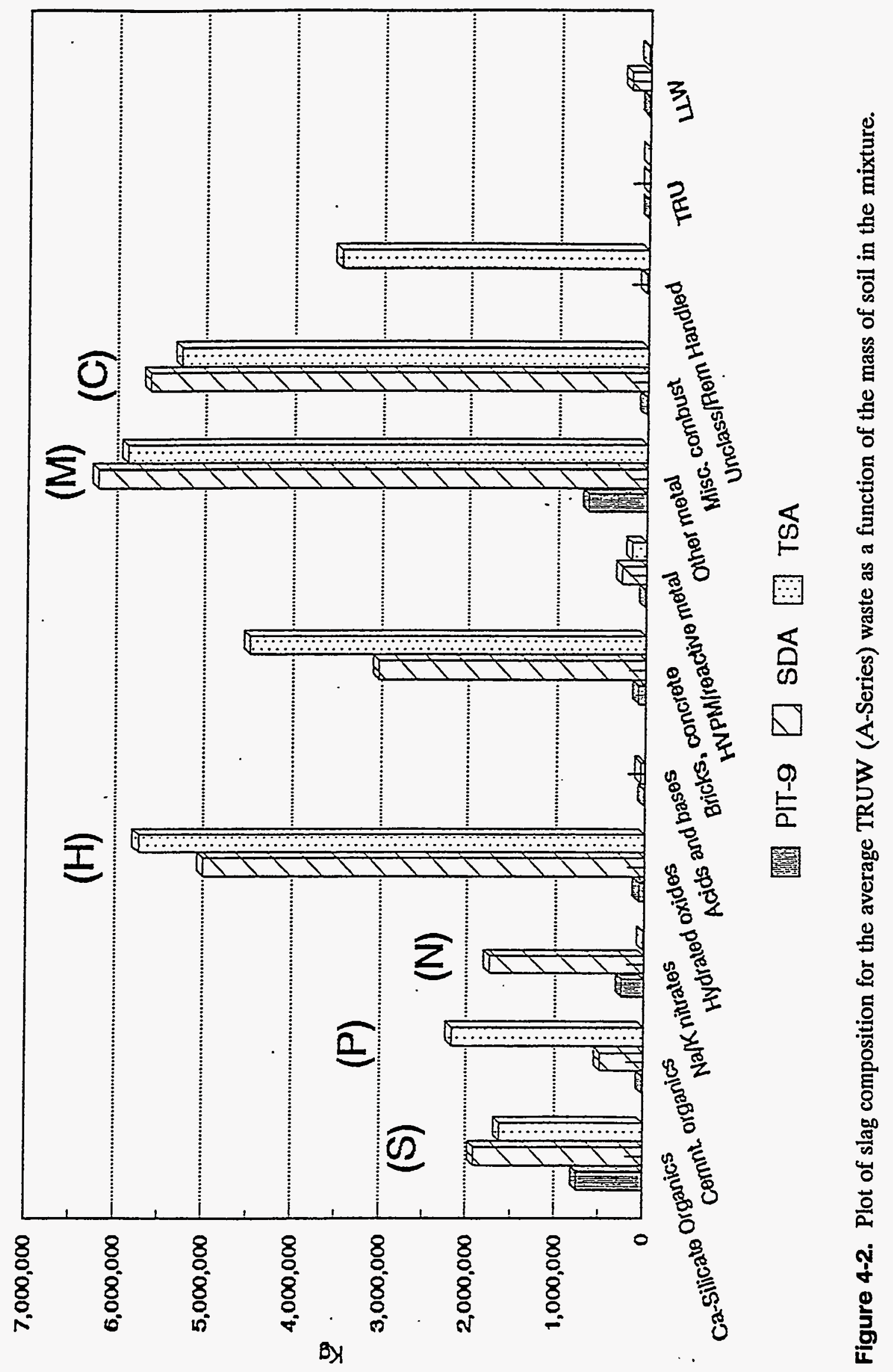




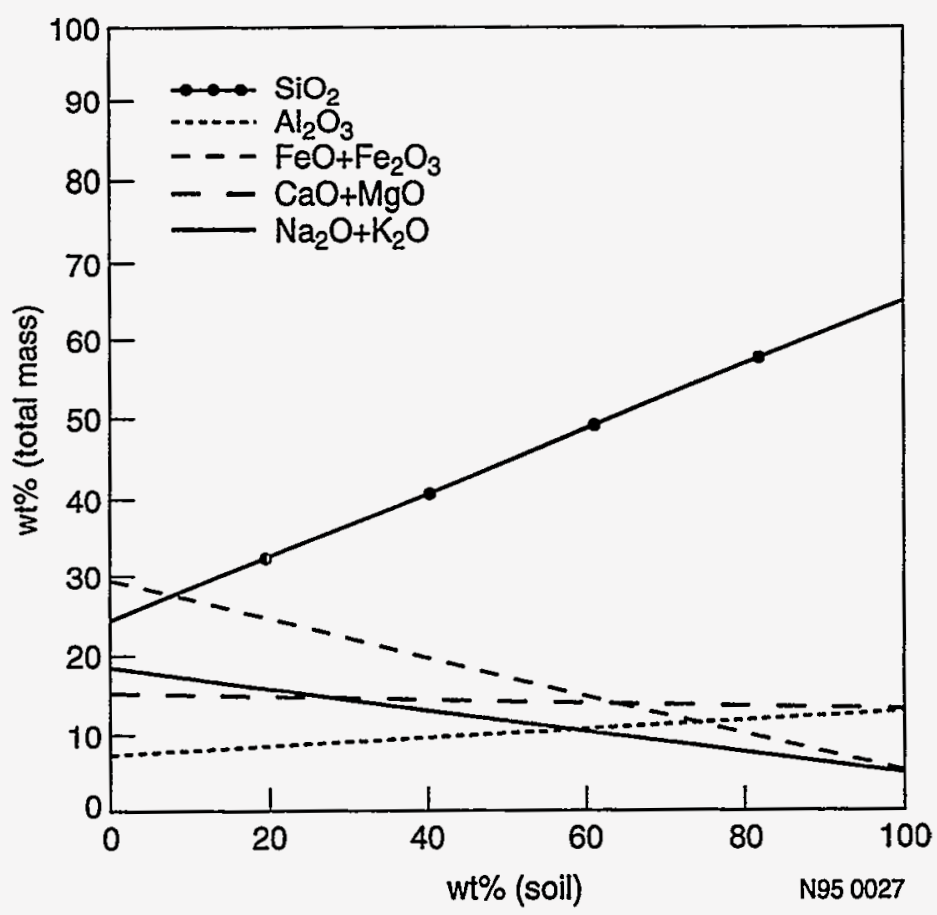

Figure 4-3. Plot of slag composition for the RFP 741 hydrated metal oxide (H1-Series) waste as a function of the mass of soil in the mixture.

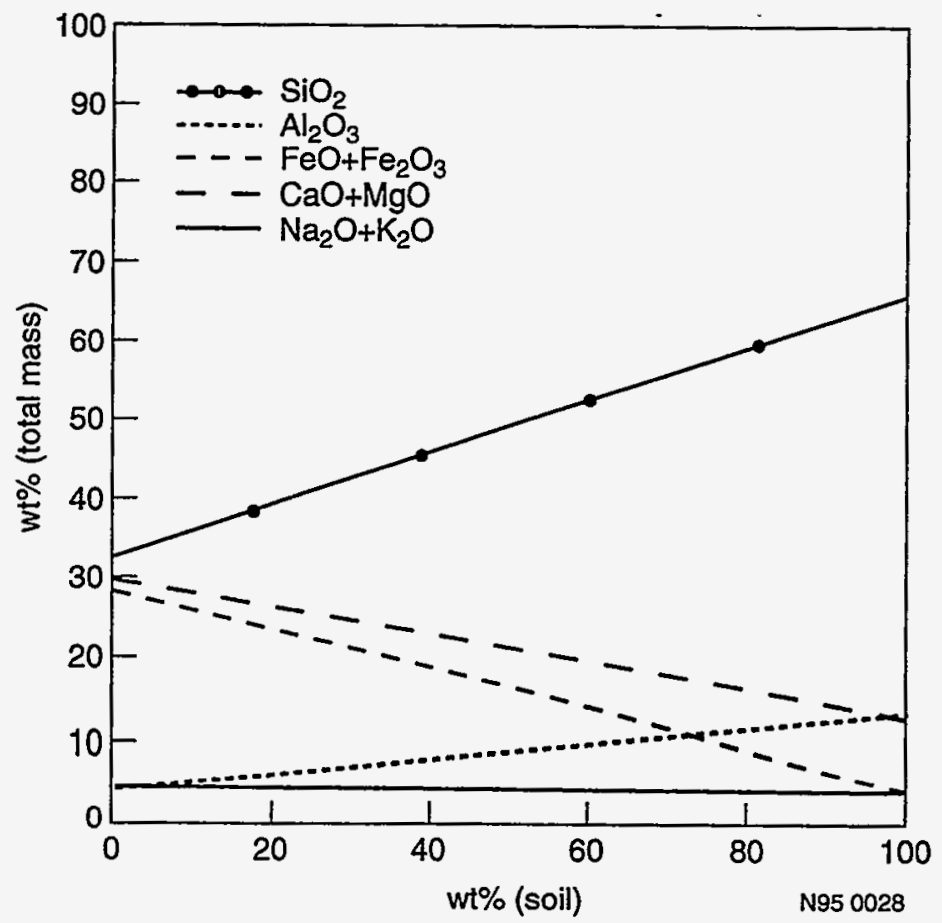

Figure 4-4. Plot of slag composition for the RFP 742 hydrated metal oxide (H2-Series) waste as a function of the mass of soil in the mixture. 


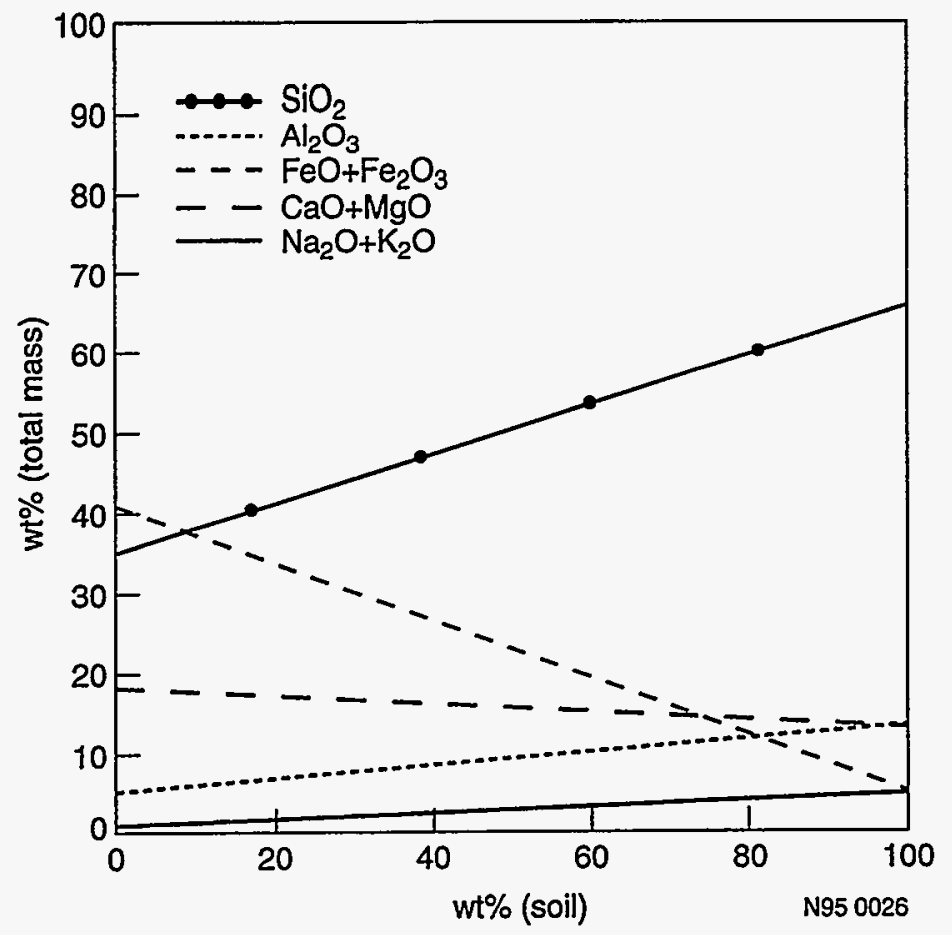

Figure 4-5. Plot of slag composition for the RFP 743 calcium-silicated (S-Series) waste and organic sludge as a function of the mass of soil in the mixture.

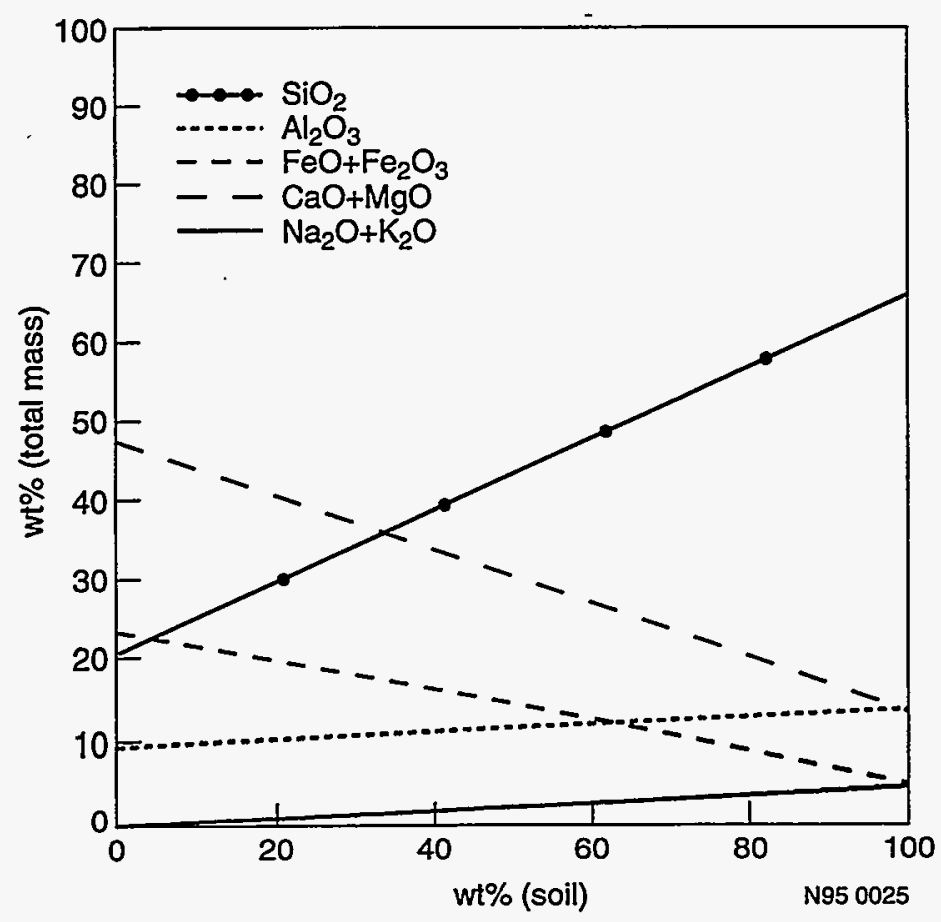

Figure 4-6. Plot of slag composition for the RFP 744 Portland-cemented organic sludge ( $P$ Series) waste as a function of the mass of soil in the mixture. 


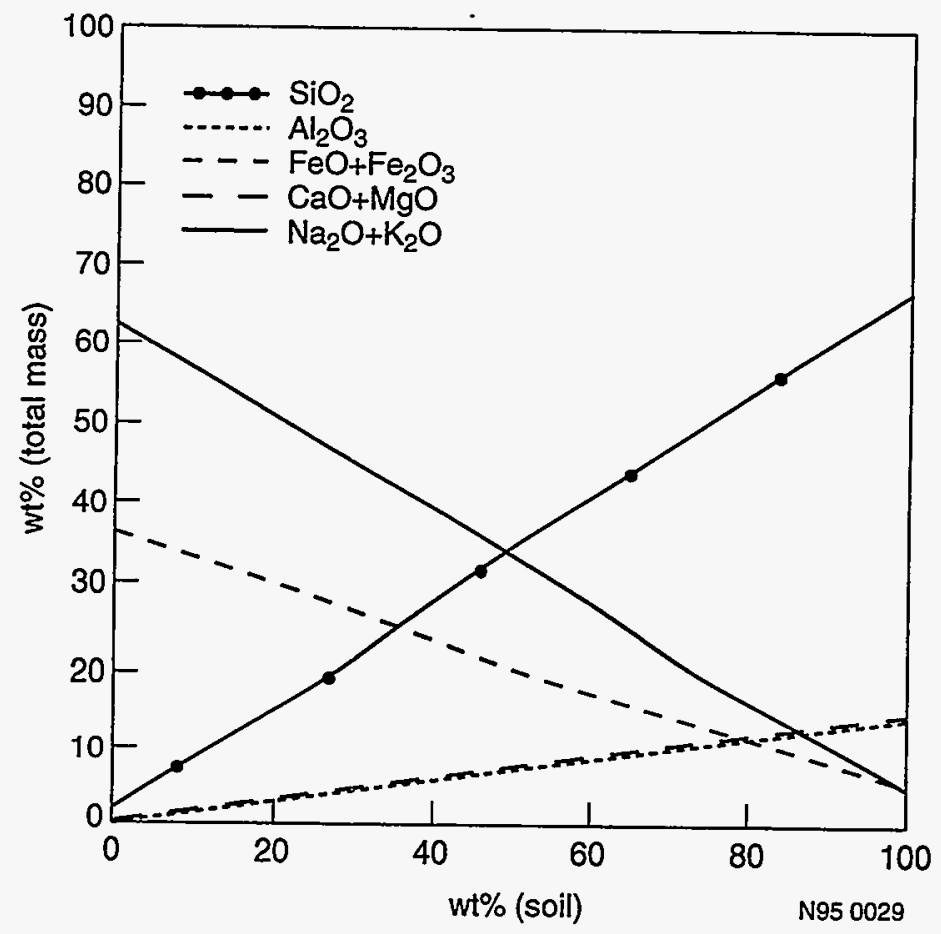

Figure 4-7. Plot of slag composition for the RFP 745 alkali-nitrate evaporator salt (N-Series) waste as a function of the mass of soil in the mixture.

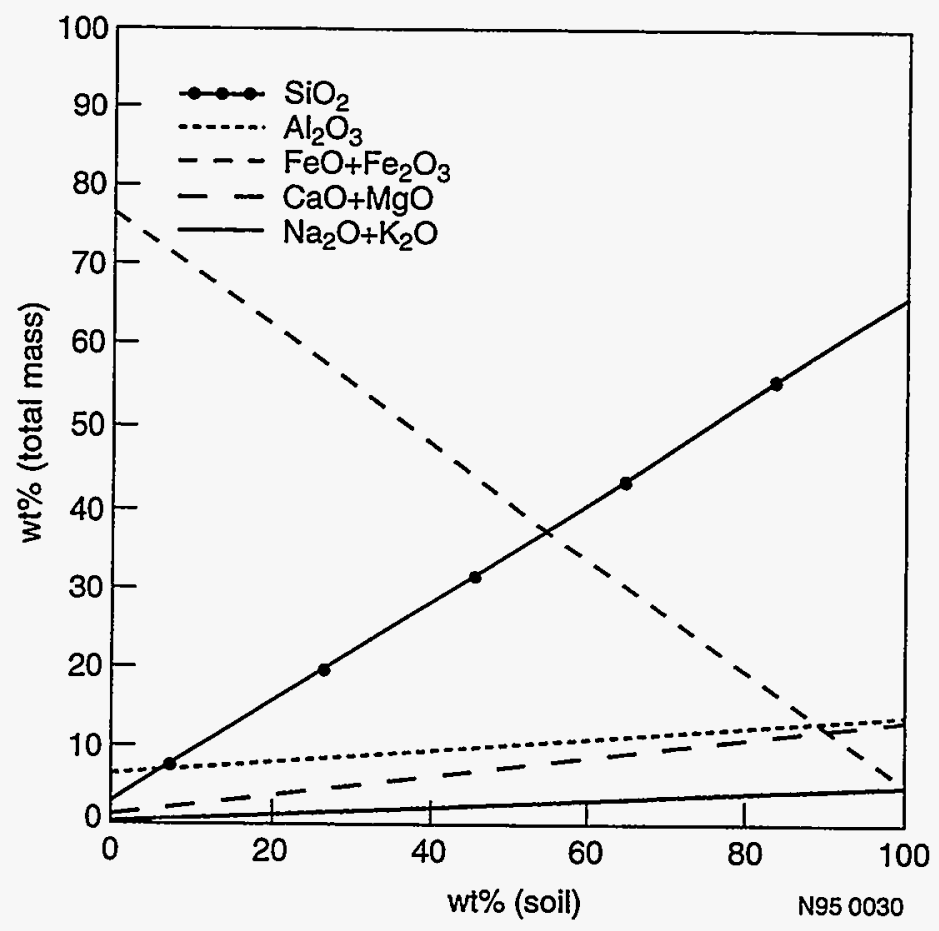

Figure 4-8. Plot of slag composition for the nonspecial source metallic (M-Series) waste as a function of the mass of soil in the mixture. 
Some molten slag properties have been measured previously (Flinn 1981a), summarized more recently (Reimann et al. 1992), and used in models (Grandy, Eddy, and Anderson 1993). Measured IEB viscosities, electrical conductivities, and specific heats as a function of temperature and composition are shown in Figures 4-9 through 4-11, respectively.

If it is desired to stay within the IEB compositional range, additives such as soil and mixing waste streams to buffer compositional variations are necessary. However, recent research has shown that final waste forms for some of the major streams are satisfactorily stable and leach resistant even though their composition is not in the IEB range.

For the $\mathrm{H1} 1 \mathrm{H} 2$, S, and P series wastes, $40-60$ wt\% soil in the slag results in a slag composition within the range of a desirable IEB waste form. The ratio of iron oxides to silica is a major indicator of IEB composition. For A-40, the iron oxides to silica ratio is 0.384 . In the case of the evaporator salts, a $50 \%$ soil addition results in a suitable iron oxides-to-silica ratio, but the alkaline content $(\approx 40 \%)$ is outside the IEB composition range. The metallic waste requires a higher percentage of soil to be added $(\approx 70 \%)$ to get an IEB composition similar to A-40. Since metals are a substantial part of the stored waste, the metals may be treated by (a) mixing the metals with wastes from other waste streams, or (b) operating the melter to avoid oxidizing these metals and produce a disposable or recyclable metal secondary stream. These approaches would preclude having to add large amounts of soil or other additives just to achieve the desired slag waste form.

Soil additions used in calculations and mass balances of Section 5 are less than those specified above. Recent studies have shown that the waste form can have adequate waste form characteristics without having an IEB composition, allowing lesser amounts of soil to be added.

\subsection{Final Waste Form Options}

Possible final waste forms include many low-temperature and high-temperature waste forms, as shown in Table 4-6 for selected waste forms. The historical aspects of waste form development are shown graphically in Figure 4-12. Some of the characteristics of various final waste forms are summarized in Table 4-7. The relative quality of high-temperature (glass-ceramic) final waste forms is given in Table 4-8.

Major considerations for waste form selection are the appropriate stability and volume reduction to minimize disposal costs. For high-level radioactive wastes, the stability of highly concentrated radionuclides is very important, and volume reduction is less important. For low-level radioactive wastes (including ALLW and TRUW), the relative volume of the wastes is larger, and volume reduction is a major issue. If the additives (for stability or processability) can be reduced, the volume will be reduced.

In the case of the INEL ALLW/TRUW streams, most of the ash or residue after combustion of organics and removal of chlorides can be made very stable with a minimum of additives. This gives maximum volume reduction. If the metal (mostly iron) and/or drums are oxidized and added to the slag, the resultant composition more closely resembles an iron-enriched basalt. Thus, the waste requires minimal additives to obtain an excellent waste form. 


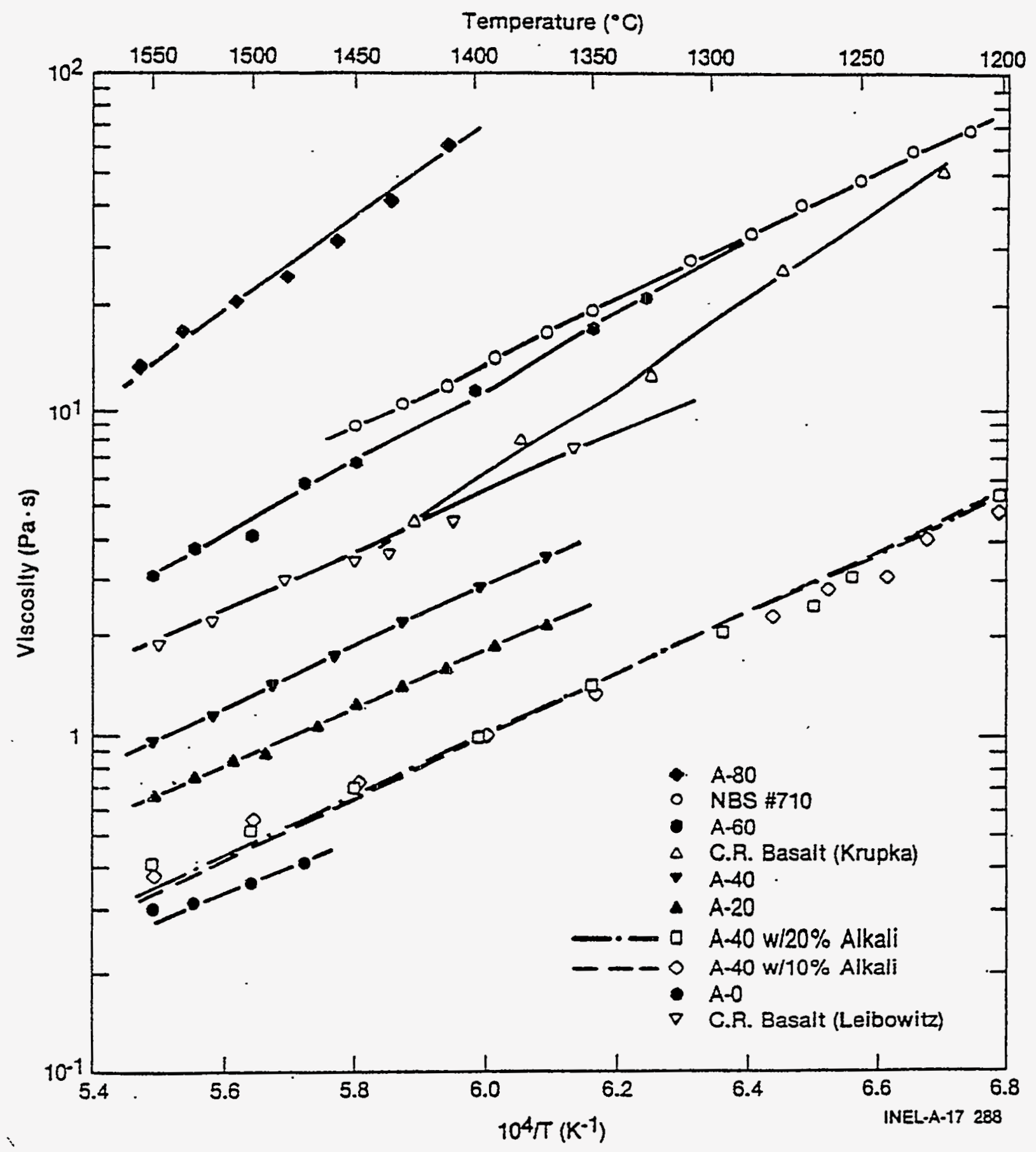

Figure 4-9. Molten basalt viscosity as a function of temperature for the A-Series compositions.

Contaminated soil added to the melt can even further improve the leach resistance and other properties.

In conclusion, the ALLW/TRUW streams can produce an IEB final waste form after melting with minimal soil addition. Advantages of IEB waste forms include the following:

- IEB can handle the high amount of iron and aluminum in the RWMC waste streams. 


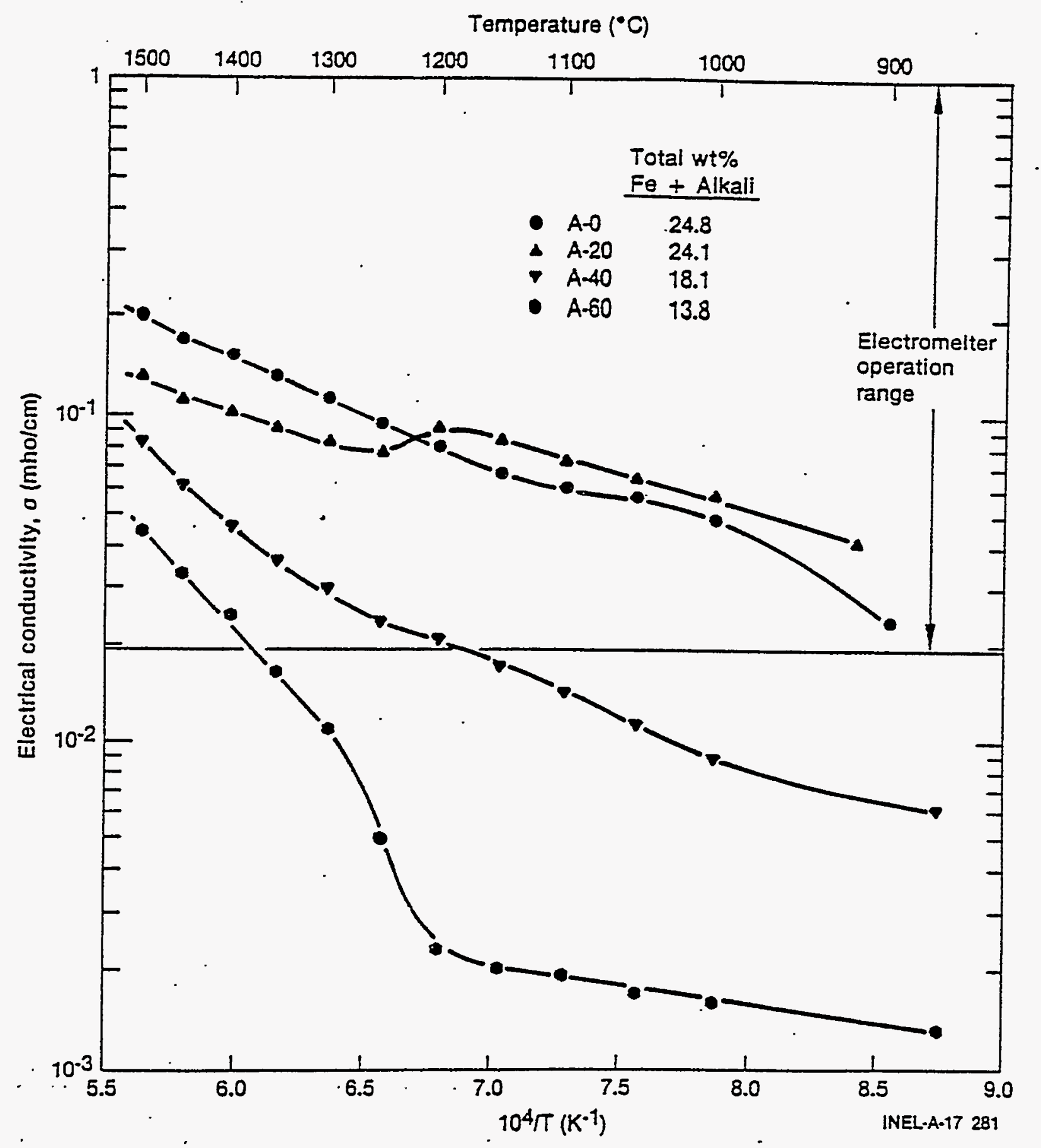

Figure 4-10. Molten basalt electrical conductivity as a function of temperature for the A-Series compositions.

- The IEB leach resistance to toxic materials far exceeds Toxicity Characteristic Leachability Procedure (TCLP) requirements.

- The IEB leach resistance for individual elements exceeds BSG performance, which is the only presently approved HLW waste form.

- IEB has high structural integrity, with a compressive strength greater than $400 \mathrm{MPa}$ and no respirable fines by standard tests. 


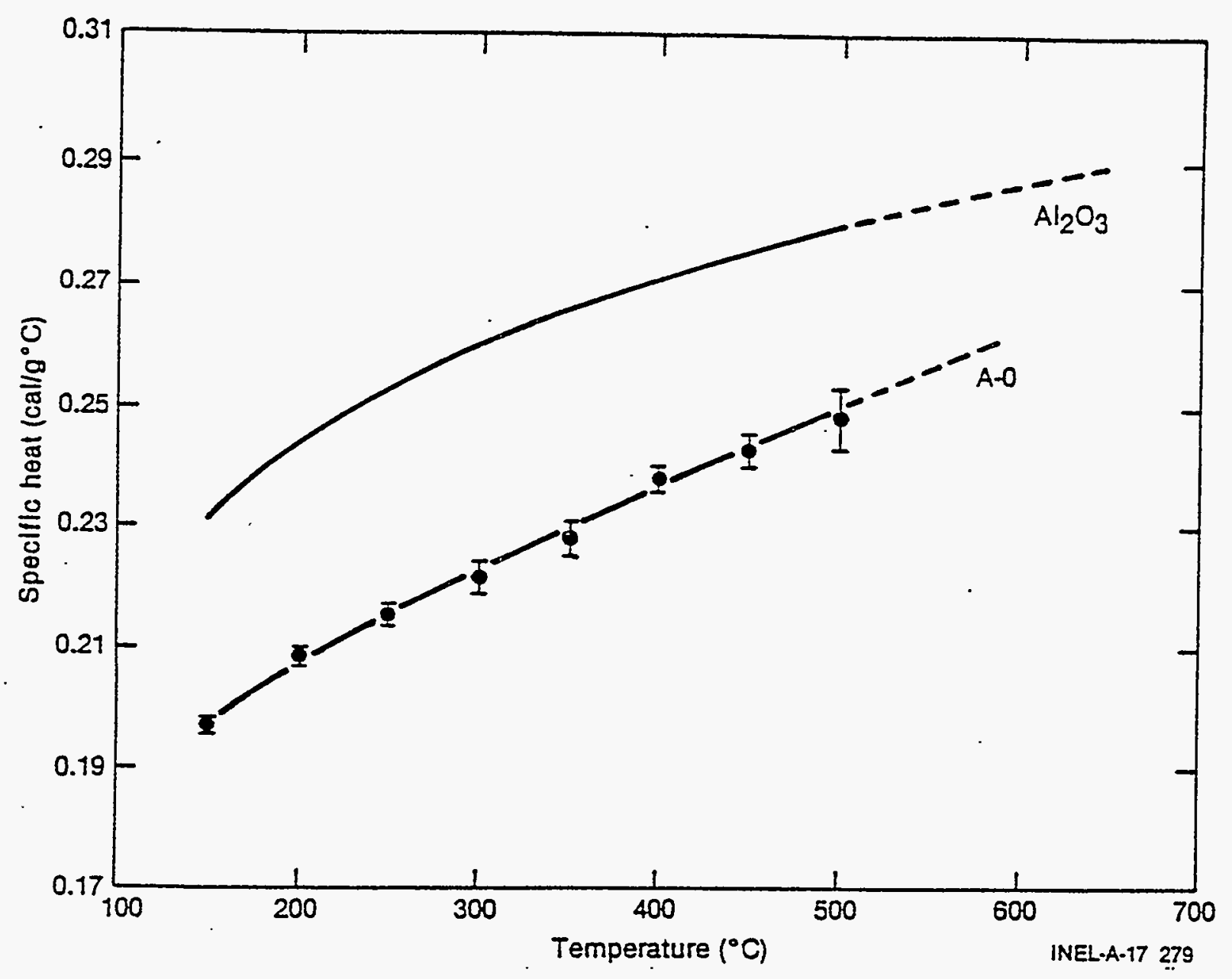

Figure 4-11. Specific heat capacity as a function of temperature for A-0 composition slag with $\mathrm{Al}_{2} \mathrm{O}_{3}$ used as a reference (Reimann et al. 1992).

- IEB can be modified to IEB4 with small additions of $\mathrm{TiO}_{2}$ and $\mathrm{ZrO}_{2}$, which essentially make the transuranics unavailable for leaching.

- The natural analog of IEB/IEB4 is basalt, which has demonstrated stability over geological time frames. 
Table 4-6. Final waste form options for different waste streams.

ANS = ANS STD. 16.1, AP = Applicable, APPR = Approved by DOE, EX = Exceeds requirements, TCLP-EPA Toxicity Leach Procedure Test, NA $=$ Not applicable.

\begin{tabular}{|c|c|c|c|c|c|c|c|c|c|c|c|}
\hline \multicolumn{6}{|c|}{ Low-temperature waste forms } & \multicolumn{6}{|c|}{ High-temperature waste forms } \\
\hline Waste & Bitumen & $\begin{array}{c}\text { Portland } \\
\text { cement }\end{array}$ & Plastic & $\begin{array}{c}\text { FUETAP } \\
\text { cement }\end{array}$ & $\begin{array}{l}\text { Sulfur } \\
\text { polymer } \\
\text { cement }\end{array}$ & BSG & $\begin{array}{l}\text { Alumino- } \\
\text { silicate } \\
\text { glass }\end{array}$ & $\begin{array}{l}\text { Phosphate } \\
\text { glass }\end{array}$ & $\begin{array}{l}\text { Glass- } \\
\text { ceramic }\end{array}$ & $\begin{array}{c}\text { IEB4 } \\
\text { and IEB }\end{array}$ & Synroc \\
\hline HLW & NA & NA & NA & NA & NA & APPR & AP & AP & AP & AP & $\mathrm{AP}$ \\
\hline TRUW & NA & NA & NA & NA & NA & $\mathbf{A P}$ & $\mathbf{A P}$ & $\mathrm{AP}$ & $\mathbf{A P}$ & AP & AP \\
\hline RTRU & NA & NA & NA & NA & NA & $\mathrm{AP}$ & AP & $\mathrm{AP}$ & AP & AP & AP \\
\hline LLW & ANS & ANS & $?$ & ? & $?$ & EX & EX & EX & EX & EX & EX \\
\hline Toxic & TCLP & TCLP & TCLP & TCLP & TCLP & AP & AP & AP & AP & AP & AP \\
\hline
\end{tabular}




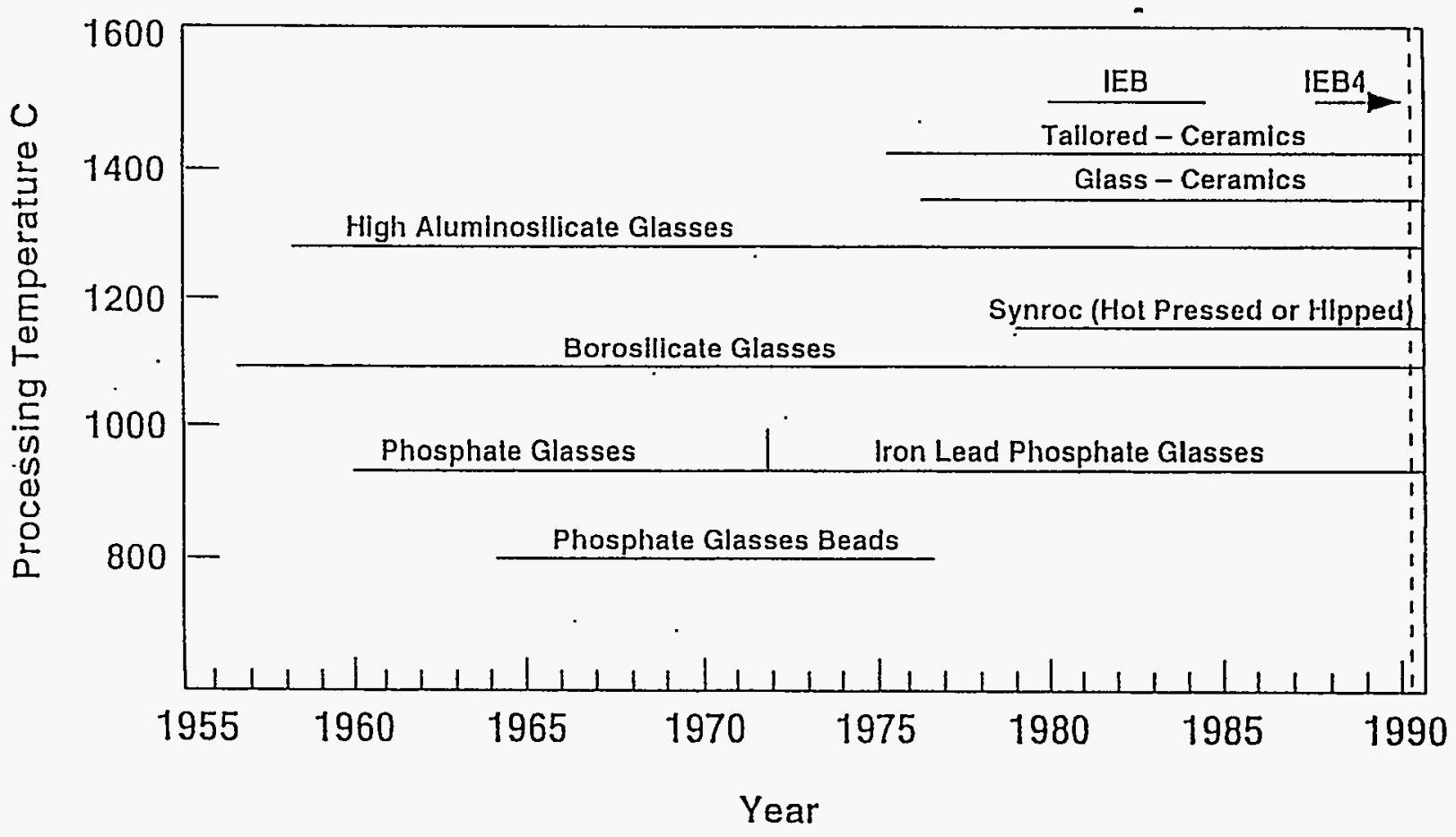

Figure 4-12. History of glass and ceramic waste form development. 
Table 4-7. Selected properties for various waste forms (all organics are assumed to have been combusted).

\begin{tabular}{|c|c|c|c|c|c|c|}
\hline Final waste form & $\begin{array}{l}\text { Maximum } \\
\text { waste loading } \\
\text { for average } \\
\text { composition }^{\mathrm{a}, \mathrm{b}}\end{array}$ & $\begin{array}{l}\text { Specific } \\
\text { gravity }\end{array}$ & $\begin{array}{c}\text { Bulk } \\
\text { leach rate } \\
\left(g / \mathrm{m}^{2} \mathrm{~d}\right)\end{array}$ & Advantages & Disađivantages & $\begin{array}{l}\text { Recommendation } \\
\text { ALLW/IRUW }\end{array}$ \\
\hline $\begin{array}{l}\text { Portland cement } \\
\text { concrete } \\
\text { (PCC) }\end{array}$ & $40 \%$ & 1.9 & $\begin{array}{l}\text { Not } \\
\text { available }\end{array}$ & $\begin{array}{l}\text { Simpler, } \\
\text { encapsulates } \\
\text { HVPM }\end{array}$ & $\begin{array}{l}\text { C \& S, } \\
\text { porous leach and } \\
\text { physical } \\
\text { durability, } \\
\text { heterogeneous wastes }\end{array}$ & $\begin{array}{l}\text { No longer being used } \\
\text { for } L L W \text { in most } \\
\text { places because } \\
\text { preference depends on } \\
\text { feedstock }\end{array}$ \\
\hline $\begin{array}{l}\text { FUETAP } \\
\text { concrete }\end{array}$ & $40 \%$ & 2.0 & 0.3 & $\begin{array}{l}\text { Simpler, } \\
\text { encapsulates } \\
\text { HVPM, better } \\
\text { than PCC }\end{array}$ & $\begin{array}{l}\text { Cl \& S, } \\
\text { porous leach and } \\
\text { physical } \\
\text { durability, } \\
\text { heterogeneous wastes }\end{array}$ & $\begin{array}{l}\text { No longer being used } \\
\text { for } L L W \text { in most } \\
\text { places because } \\
\text { preference depends on } \\
\text { feedstock }\end{array}$ \\
\hline $\begin{array}{l}\text { Sulfur polymer } \\
\text { cement/concrete } \\
\text { (SPC) }\end{array}$ & $40 \%$ & 2.4 & $\begin{array}{l}\text { Not } \\
\text { available }\end{array}$ & $\begin{array}{l}\mathrm{Hg}, \mathrm{Pb}, \mathrm{Cs} \\
\text { compositions } \\
\text { requirement } \\
\text { TCLP unknown }\end{array}$ & $\begin{array}{l}\text { Resins, } \\
\text { Cl?, } \\
\text { TRU, U? }\end{array}$ & $\begin{array}{l}\text { Little is known about } \\
\text { compositional } \\
\text { variations on } \\
\text { performance }\end{array}$ \\
\hline $\begin{array}{l}\text { Borosilicate glass } \\
\text { (BSG) }\end{array}$ & $30 \%$ & 26 & 0.4 & $\begin{array}{l}\text { Pass TCLP, } \\
\text { long life } \\
\text { for TRU, U }\end{array}$ & $\begin{array}{l}\text { Some HVPM, Cl } \\
\text { emissions, }{ }^{c} \text { glass } \\
\text { composition limits }\end{array}$ & $\begin{array}{l}\text { Glass composition } \\
\text { requires more } \\
\text { additives. }\end{array}$ \\
\hline $\begin{array}{l}\text { Aluminosilicate } \\
\text { glass } \\
\text { (ASG) }\end{array}$ & $60 \%$ & 2.7 & 0.07 & $\begin{array}{l}\text { Pass TCLP, } \\
\text { long life } \\
\text { for TRU, U }\end{array}$ & $\begin{array}{l}\text { Some HVPM, } \\
\text { Cl emissions }\end{array}$ & $\begin{array}{l}\text { Optimizes composition } \\
\text { and durability }\end{array}$ \\
\hline $\begin{array}{l}\text { Iron-enriched } \\
\text { basalt } \\
\text { (IEB) }\end{array}$ & $60 \%$ & 3.0 & 0.08 & $\begin{array}{l}\text { Pass TCLP, } \\
\text { long life } \\
\text { for TRU, U }\end{array}$ & $\begin{array}{l}\text { Some HVPM, Cl } \\
\text { emissions }\end{array}$ & $\begin{array}{l}\text { Optimizes composition } \\
\text { and durability }\end{array}$ \\
\hline $\begin{array}{l}\text { IEB with } \\
\mathrm{TiO}_{2} \& \mathrm{ZrO}_{2} \\
\text { (IEB4) }\end{array}$ & $60 \%$ & 3.5 & 0.05 (est) & $\begin{array}{l}\text { Pass TCLP, } \\
\text { longest life } \\
\text { for TRU, U }\end{array}$ & $\begin{array}{l}\text { Some HVPM, Cl } \\
\text { emissions }\end{array}$ & $\begin{array}{l}\text { Maximizes } \\
\text { composition and } \\
\text { durability }\end{array}$ \\
\hline
\end{tabular}

a. With the alkali nitrate (RFP 745), all waste forms are limited to $20 \%$ waste loading.

b. If metals are tapped, nonnitrate waste loadings for ASG and IEB can be increased to 70 or $80 \%$.

c. "Some HVPM, Cl emissions" indicates that offgas solids need to be recycled or stabilized separately. Most systems will need a separate chlorine compound waste form method. 
Table 4-8. Comparison of high-temperature waste form properties.

\begin{tabular}{|c|c|c|c|c|c|c|c|c|}
\hline \multirow[b]{3}{*}{ Waste form } & \multirow{3}{*}{$\begin{array}{c}\text { Process } \\
\text { temperature } \\
\left({ }^{\circ} \mathrm{C}\right) \\
\end{array}$} & \multicolumn{7}{|c|}{ Stability $^{2}$} \\
\hline & & \multirow[b]{2}{*}{ Mechanical } & \multirow[b]{2}{*}{ Thermal } & \multicolumn{4}{|c|}{ Chemical } & \multirow{2}{*}{$\begin{array}{c}\text { Metal } \\
\text { tolerance } \\
\text { during } \\
\text { production }\end{array}$} \\
\hline & & & & $\mathrm{HLW}$ & LLW & TRU & Toxic & \\
\hline Phosphate glass & $900-1200$ & $\mathbf{P}$ & $\mathbf{P}$ & $\mathbf{P}$ & $-{ }^{b}$ & $-{ }^{b}$ & - & - \\
\hline Pyrex & $1200-1500$ & $\mathrm{G}$ & $\mathbf{G}$ & $\mathrm{E}$ & $-b$ & $-b$ & - & - \\
\hline BSG & $900-1200$ & $G$ & G & $\mathrm{G} / \mathrm{E}$ & $G / E$ & $-{ }^{b}$ & G & $P$ \\
\hline $\begin{array}{l}\text { Aluminosilicate } \\
\text { glass }\end{array}$ & $1200-1500$ & $\mathrm{E}$ & $\mathrm{E}$ & $\mathbf{G}$ & $-{ }^{b}$ & $-{ }^{b}$ & - & $\mathbf{M}$ \\
\hline Glass-ceramics & $1200-1500$ & $\mathrm{E}$ & $\mathrm{E}$ & $\mathrm{G} / \mathrm{E}$ & $\mathrm{G} / \mathrm{E}$ & $-b$ & - & G \\
\hline IEB & $1500-1800$ & $\mathrm{E}$ & $\mathrm{E}$ & $-^{b}$ & $\mathrm{G}$ & G & $\mathrm{E}$ & $\mathrm{E}$ \\
\hline $\begin{array}{l}\text { IEB4 } \\
\text { (projected) }\end{array}$ & $1500-1800$ & $\mathrm{E}$ & $\mathrm{E}$ & $-^{b}$ & $\mathrm{E}$ & $\mathrm{E}$ & $\mathrm{E}$ & $\mathrm{E}$ \\
\hline Synroc & $900-1200$ & $E$ & $\mathrm{E}$ & $\mathbf{E}$ & $-^{b}$ & $-b$ & - & - \\
\hline a. E = excellent & $=$ good, $P=$ & poor. & & & & & & \\
\hline
\end{tabular}




\section{SYSTEM CONSIDERATIONS}

\subsection{General Background from 1991-92 Studies on Buried Waste}

A conceptual incineration and melting system scenario for buried waste with no sorting (other than a bulk presort of Special Case waste items), is illustrated in Figure 5-1. The scenario briefly described in the following is a representative example at this point, intended to give some understanding of an overall thermal processing system approach. The scenario and discussions summarized in Sections 5.1, 5.2, 5.3, and 5.4 are from Eddy, Kong, and Raivo (1992), wherein secondary references are cited. A simplified retrieval system is located in a temporary alpha containment building located over the pit to be excavated. An overhead crane is available to relocate oversized or highly radioactive items. The manually operated backhoe is shielded and is used for loading drums, containers, and soil into sealable bins on conveyor belts. The bins are sealed, assayed for content, and transported to the processing building where they are routed into the appropriate order and feed line to be emptied into the sizing unit.

After sizing, the unsorted waste goes through a thermal desorption pyrolysis process to decompose volatilize and combust organics and other volatiles at low temperature. The gaseous products from the incinerator are routed to an afterburner to ensure sufficient destruction efficiency. Offgases from the melter also go to the afterburner. The offgas treatment system removes any volatilized metal compounds, halogen and sulfur compounds (acid gases), and other precipitable compounds. These are treated later as a secondary waste stream, as necessary.

The nonvolatile, noncombustible solids from the incinerator are then fed into the melter. In the melter, the new solids (feed burden) may form a partial or complete cold cap over the slag melt which may help to inhibit loss of the high vapor pressure metals and their oxides. The middle layer in the melter is the molten slag composed of silica and metallic oxides. Natural convection currents in the slag promote mixing for the desired reactions and homogeneity. Metals will melt (with the melter at sufficiently high temperature) and sink to the bottom of the melter.

When mixed with soil, most of the organics, acids, bases, and reactive metals are buffered and not expected to present significant thermal processing problems. In the melter environment, complex chemical compounds will decompose into oxides in the slag or produce pyrolyzed gases. Some of the high vapor pressure (volatile) metals (HVPMs) such as $\mathrm{Pb}, \mathrm{Zn}, \mathrm{Hg}, \mathrm{Cs}-137$, etc., will partition to the offgas for removal and secondary treatment for disposal. Depending on operating conditions, portions of these metals may remain in the slag. Periodically or continuously, slag is tapped, cast, and cooled to form the desired glass/ceramic waste form. Periodically, liquid metal (mostly iron) may be tapped out of the melter. These products are then assayed and routed to the appropriate disposal site.

The entire thermal processing system from the sizing unit to the offgas treatment system exhaust and the waste form packaging unit is enclosed for alpha containment. The melter configuration shown is a 3-phase, ac graphite electrode submerged-arc melter. Other melter types and configurations are possible. 


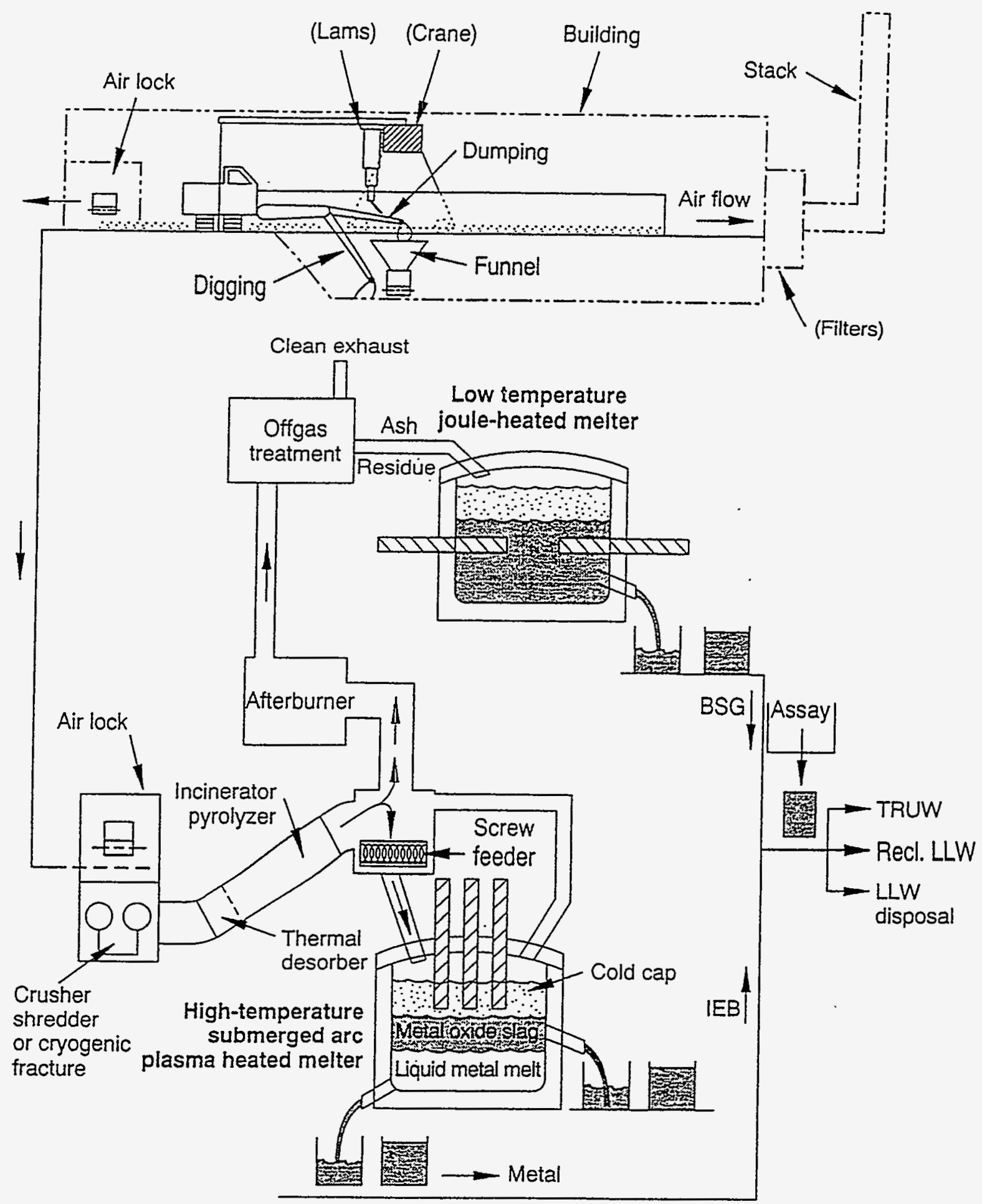

N92 0026

Figure 5-1. A conceptual (not to scale) incineration and melting system with no sorting (other than special case). 
Figure 5-2 shows an approximate mass flow input-output diagram based on estimated input waste stream (buried waste studies 1992) quantities and compositions. Though approximate, it gives a rough idea of the relative amounts of different waste materials to be processed. The largest fractions of the waste by mass (in descending order) are metals, combustibles, hydrated oxides, bricks, and concrete, silicated organics, and nitrates. The amount of oxygen required to oxidize the metal was determined by assuming $30 \%$ of the metal is oversize and sorted out, $55 \%$ is tapped as pure reduced melted metal, and only the remaining $15 \%$ is surface oxidized to remove contaminants. In this average composition scenario, no soil is added. If soil is added, the final waste form mass will increase by about $85 \%$ of the amount of soil added (since the soil is about $15 \%$ moisture, water of hydration, and carbonates). Soil could be added to provide buffering and to minimize variations in the slag composition for different wastes.

The INEL stored wastes located at the TSA are very similar in composition to the buried waste described above but have lesser quantities of soil.

\subsection{Criteria and Requirements for the Final Waste Form}

Development of a final waste form for nuclear wastes and nonnuclear hazardous waste has focused on various vitreous/ceramic waste forms, including borosilicate, high-silica glass (Pyrex), high alumina silicate glasses, iron-enriched basalt (IEB), glass-ceramics, and phosphate glasses. Consideration of all parts of the waste disposal system ensures that the final product will safeguard the public, and that the production process used will be safe, efficient, and environmentally sound to operate. The system engineering development approach requires that parameters affecting product performance and processing conditions be considered

simultaneously. Parameters affecting product performance, such as chemical stability, waste form leachability, thermal stability, mechanical durability, impact resistance to generate breathable fines, radiation damage resistance, and environmental compatibility, must be ensured and optimized, relative to processing parameters such as melt temperature and viscosity, electrical and thermal conductivities of the melt, waste solubility, melt corrosivity, and volatility of high vapor hazardous species.

Borosilicate glasses (BSGs) are, overall, the most studied glasses for immobilizing nuclear wastes. Some phosphate glasses are highly durable, but the glass melts are highly corrosive to the melter even at $900^{\circ} \mathrm{C}$, have poor thermal stability, and have low solubility for many waste components. On the other hand, iron enriched basalt (silica composition ranges from 40-60 wt\%) waste forms, glass-ceramics, and high alumina silicates have high chemical stability, high thermal stability, high mechanical stability, and good environmental compatibility, but their associated high melting temperatures potentially increase the volatilization of hazardous waste species during processing. The fabrication of these final waste forms requires the use of hightemperature melters. The borosilicate glasses melt at much lower temperatures than other hightemperature waste forms and are generally less corrosive to the melter. The low melting temperatures of borosilicate glasses minimize excessive volatilization of toxic metals and radionuclides from the melt.

However, BSG is not readily applicable to waste stored at the INEL RWMC. BSG requires a well characterized waste stream composition and is incapable of handling highly varying 


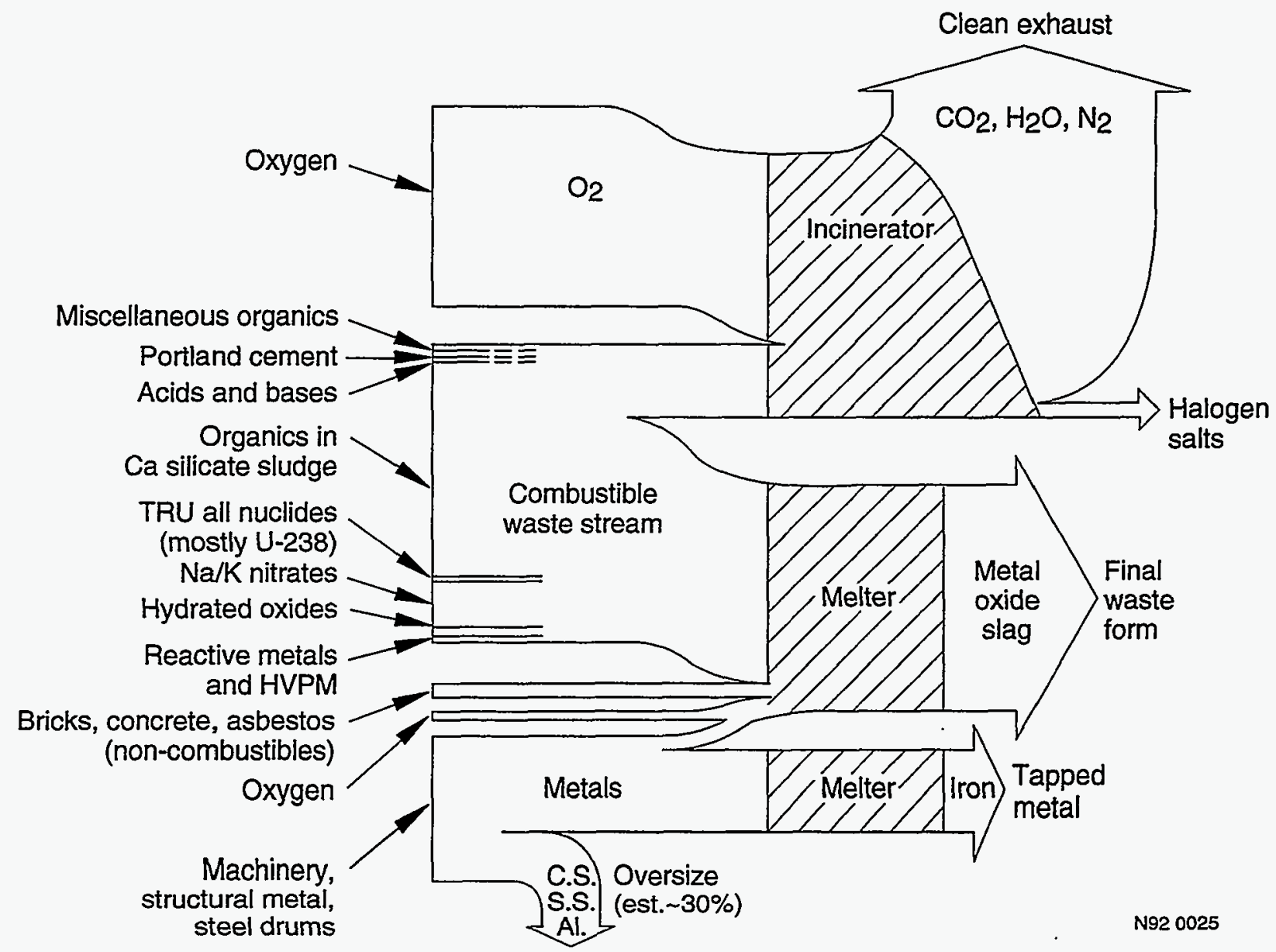

Figure 5-2. An approximate mass flow diagram of input waste streams and output waste forms based on estimated values.

heterogeneous waste streams. Because of the low processing temperatures, BSG processes cannot melt higher melting-temperature materials such as iron and basaltic soil. The fabrication of BSG final waste forms require large additions of $\mathrm{B}_{2} \mathrm{O}_{3}$, alkaline oxides, alkaline earth oxide, and glass frits. The INEL TRU mixed wastes and associated contaminated soil are heterogeneous and their compositions vary between extremes. Retrieving and converting this type of TRU mixed wastes to BSG is impractical if not impossible. The process would require costly efforts to separate all the high melting metals, a large addition of glass-forming materials, and a tight control of the waste stream compositions. The large quantity of glass forming materials needed to produce BSG could potentially produce a higher volume of final waste form than originally input for treatment.

Based on disposal volume considerations, waste form performance and integrity, and the ability of the waste form to meet or exceed current fluctuating and future regulatory constraints, the waste form must be a high-performance, leach-resistant, high-quality waste form of equal to or better than performance when compared to the HLW standard BSG waste form. The ability to correlate the produced waste form to a natural analog having demonstrated lifetimes in the millions of years would be desirable. 
From the general design stand point, the final waste form must possess the following characteristics: (a) chemical stability, (b) thermal stability, (c) mechanical durability, (d) high leach resistance, (e) high impact resistance to generate breathable fines, (f) macroscopic homogeneity in terms of overall waste form properties performance, $(\mathrm{g})$ high waste loading capability, and $(h)$ high stability to internal alpha, beta, and gamma radiation damage.

From the specific design stand point, the final waste form must meet the following requirement assumptions: (a) plutonium and other TRUs will be dissolved, oxidized, and chemically incorporated into the silicate melt, (b) short lived fission products will be dissolved, oxidized, and chemically or physically incorporated into the melt or volatilized from the melter and collected down-stream of the melter unit for separate disposal, (c) HVPMs will be either incorporated into the silicate melt or volatilized from the melter and collected down-stream of the melter unit for separate disposal, (d) the final waste form should enable a high concentration of $\mathrm{Fe}$ and $\mathrm{Al}$ to be chemically dissolved because they are the major components of the waste stream and this would enable the simplest processing of the highly heterogeneous waste streams, and (e) the final waste form will not contain organic residues and water of hydration so that hydrogen generation due to radiolysis will not become a problem because the final waste form is produced at very high temperatures.

In view of the above general and specific requirements, a generally classified basaltic glass-ceramic waste form has been chosen as the most suitable final waste form to immobilize the INEL TRU mixed wastes. The basaltic final waste form possesses the following desirable critical characteristics as compared to BSG: (a) both fine-grained and coarse grained basaltic final waste forms have demonstrated a much better leach resistance for uranium than BSG and high silicate glasses, (b) basaltic waste forms generally exhibit better mechanical and thermal stability than BSG, (c) the basalt FWF production process has high tolerance for all metals, including high melting temperature metals, (d) the basaltic waste form is very accommodating to highly heterogeneous waste streams with varying compositions, (e) the basalt production processes produce very high volume reduction of the input waste streams, and (f) the properties of the basaltic final waste forms are comparable to the natural basaltic rock analogs which have demonstrated lifetimes of millions of years.

The INEL soil is basaltic and is among the waste streams at the site. The chemical compositions of the wastes themselves can be generally included in basaltic characterization; therefore, the basalt based glass-ceramic final waste form is a natural choice for immobilization and stabilization of the INEL radioactive mixed hazardous wastes.

The systems and processes necessary to produce this final waste form or its improved variation the iron enriched basalt (IEB), as the primary waste form under the constraints of radioactive and hazardous operations are the present focus of design efforts. It is also recognized that in order to produce the basaltic waste as the primary waste form that secondary and possibly tertiary waste forms may necessarily be generated by the total thermal treatment processing system. Secondary waste forms may include those that can be produced at lower temperatures such as borosilicate glass (BSG), portland cement concrete (PCC), sulfur polymer cement concrete, or polyethylene encapsulation. Tertiary waste forms may include more special case waste forms for select by-product streams. These could possibly include the chloride salts and 
amalgams. A more in depth background discussion on final waste forms resulting in the designation of the basaltic natural analog approach is presented by Eddy, Kong, and Raivo (1992).

\subsection{Melter Processes}

There are several primary within-melter process issues that influence the product of the process and the capability of the melter. As presently identified, these are (a) slag viscosity, (b) slag electrical conductivity, (c) materials corrosion/erosion, (d) slag chemistry and TRU retention, and (e) slag chemistry and HVPM metals retention.

\subsubsection{Slag Viscosity}

The composition and temperature of the melt determine its viscosity and thermal and electrical conductivity; hence, they determine the fluidity and uniformity of the melt. Increasing the silica or alumina content increases the viscosity and decreases the fluidity. Adding fluxes, such as alkali metals ( $\mathrm{Na}, \mathrm{K}$, etc.) or alkali earth metals $(\mathrm{Ca}, \mathrm{Mg}$, etc.) compounds decrease the viscosity. Alkali metal oxides are dissolved into the glassy phases and not the crystalline, from which they have a higher susceptibility to leach and affect the leachability of other dissolved substances. As a result, alkali content in the slag should be minimal. Figure 5-3 illustrates the effect of adding flux to the slag melt.

\subsubsection{Slag Electrical Conductivity}

Joule-heated melters require the electrical conductivity of the melt to be in an acceptably narrow range in order to obtain the optimum heating. If the electrical conductivity is too low, the current will be too low, and the heating power will be too low. If the electrical conductivity is too high, the bath will be short circuited and will not heat as large a volume. Melted metal collected

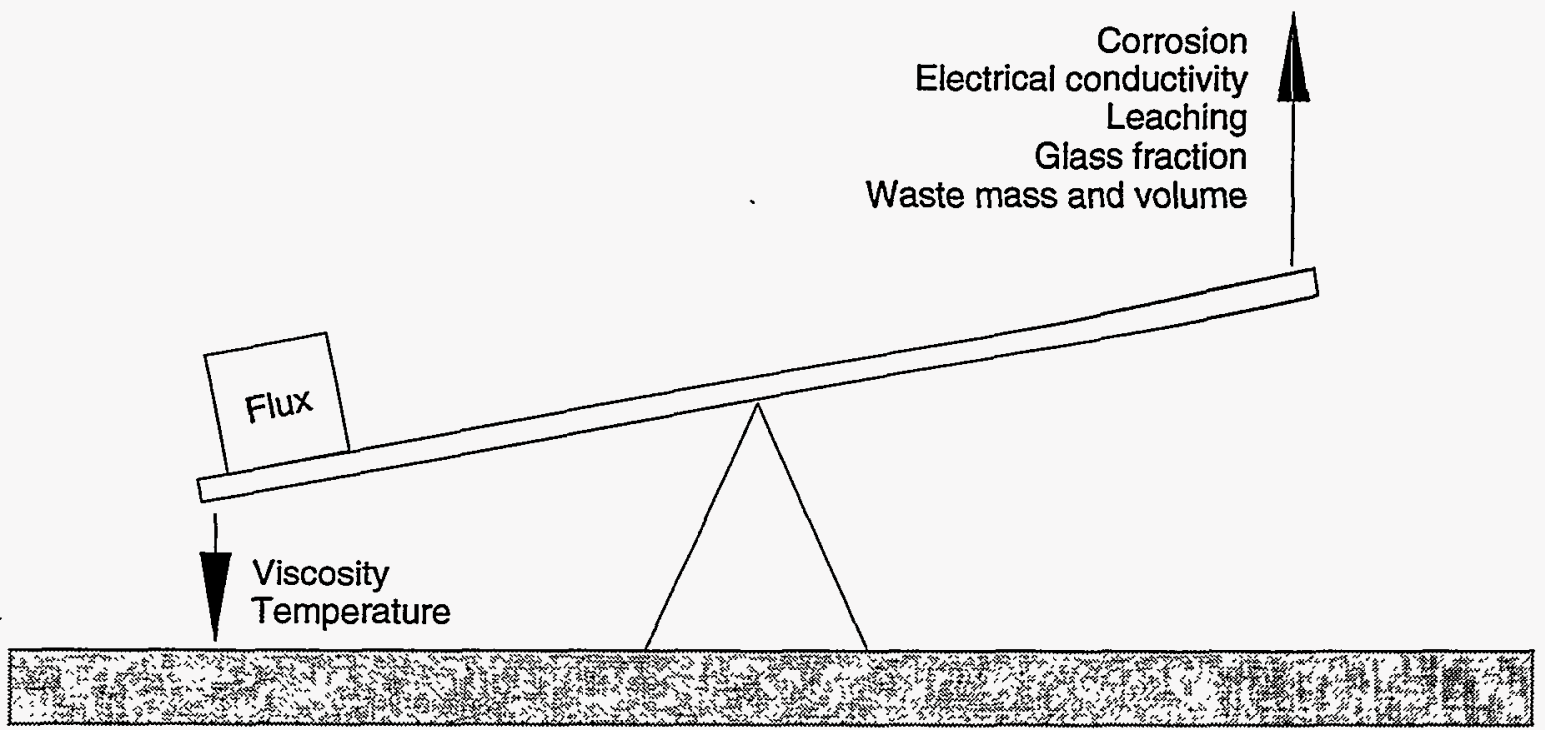

N92 0027

Figure 5-3. Illustration of the effect of adding flux to the slag melt. 
at the bottom of the bath can short out the electrodes. Because of this constraint on electrical conductivity (and viscosity), Joule-heated melters are limited to a relatively narrow range of composition changes around the design point. This limitation is not amenable to the wide variations in RWMC waste streams expected. An extensive sorting, sampling, and control system would have to be developed to enable Joule-heated melters to be used for processing the RWMC waste streams.

In arc/plasma-heated melters, the viscosity is controlled by temperature and electrical conductivity is not a major factor. Transferred arc and plasma torch-heated melters do have a Joule-heating component; but arc/plasma radiation, strong arc-generated convection, and conduction heating at the electrode attachment region are usually the dominant heating mechanisms. The main disadvantage of the arc/plasma-heated melters for waste processing is the potential for increased vaporization of HVPM at higher processing temperatures.

\subsubsection{Corrosion}

Corrosion can occur at the refractory wall near the slag surface, usually caused by convective currents in the slag and oxidation or other chemical reactions among the gas, slag, and refractory materials. These problems are accelerated at higher temperatures. With the intense energy disposition possible with plasma/arc heating, the melter walls are often water cooled and a skull of the slag material is built up to protect/replace the refractory. These problems depend on melter configuration and materials.

Corrosion of the electrodes will occur in both Joule-heated and arc-heated melters. Water-cooled copper electrodes in high-powered plasma torches typically operate for periods of less than 1,000 hours between maintenance. Oxidation of consumable graphite electrodes in arc-heated melters is accounted for in the melter design, and can be minimized by operating with a reducing gas-phase, coating the electrodes or preventing contact of the electrodes with the slag. Each melter configuration has its advantages and disadvantages, which must be understood for proper design and testing in new applications.

Table 5-1 presents a matrix of waste forms and melter types. The waste form composition dictates an approximate operating temperature range, which, along with the type of electrodes used, determines allowable redox states to minimize corrosion. The type of refractory or use of a water-cooled skull is also based on composition and temperature range. Table 5-1 also indicates the types of waste streams treatable for the temperature ranges given.

\subsubsection{Slag Chemistry and Retention of TRU Nuclides}

The slag melt must be able to dissolve the TRUs and incorporate them in its matrix. The TRU metals are extremely reactive and form insoluble oxide compounds in the glass matrix or oxide solid solutions with alumina, titania, and zirconia in crystalline phases. Tailoring the slag chemistry so that ceramic phases are achieved to retain the TRU species in solid solution is highly desirable. 
Table 5-1. Processing options for using various Joule-heated and plasma-heated melters to make different viable waste forms (Eddy, Kong, and Raivo 1992).

\begin{tabular}{|c|c|c|c|c|c|c|c|}
\hline \multirow{3}{*}{$\begin{array}{l}\begin{array}{l}\text { Final waste } \\
\text { form }\end{array} \\
\text { BSG }\end{array}$} & \multirow{3}{*}{$\begin{array}{c}\begin{array}{c}\text { Temperature } \\
\text { range }\end{array} \\
\text { Low }\end{array}$} & \multirow{3}{*}{$\begin{array}{r}\begin{array}{r}\text { Melter } \\
\text { aspect }\end{array} \\
\text { Electrodes }\end{array}$} & \multirow{3}{*}{$\begin{array}{c}\begin{array}{c}\text { Joule-heated } \\
\text { melter }\end{array} \\
\text { Inconel }\end{array}$} & \multicolumn{3}{|c|}{ Arc/plasma-heated melter } & \multirow{2}{*}{$\begin{array}{c}\text { Wastestreams } \\
\text { treatable }\end{array}$} \\
\hline & & & & \multicolumn{2}{|c|}{ Transferred-arc } & \multirow{2}{*}{$\frac{\text { Nontransferred }}{\text { Metal }}$} & \\
\hline & & & & Graphite & Metal & & \multirow{4}{*}{$\begin{array}{l}\text { Combustion ash } \\
\text { Noncombustibles } \\
\text { Most soils }\end{array}$} \\
\hline & $900-1200^{\circ} \mathrm{C}$ & Atmosphere & OX/RED & -RED & OX/RED & OX/RED & \\
\hline & & Melt & OX/RED & OX/RED & OX/RED & OX/RED & \\
\hline & & Refractory & Most & Most & Most & Most & \\
\hline ASG & Medium & Electrodes & Moly & Graphite & Metal & Metal & \multirow{4}{*}{$\begin{array}{l}\text { All above plus } \\
\text { basaltic soil } \\
\text { metallic aluminum }\end{array}$} \\
\hline \multirow[t]{3}{*}{ G-C } & $1200-1500^{\circ} \mathrm{C}$ & Atmosphere & OX/RED & - RED & OX/RED & OX/RED & \\
\hline & & Melt & $-/ R E D$ & OX/RED & OX/RED & OX/RED & \\
\hline & & Refractory & Alumina & Alumina & Alumina & Alumina & \\
\hline \multirow{4}{*}{$\begin{array}{l}\text { IEB } \\
\text { IEB4 } \\
\text { Synroc }\end{array}$} & High & Electrodes & Not available & Graphite & Metal & Metal & \multirow{4}{*}{$\begin{array}{l}\text { All above plus } \\
\text { zircon sand } \\
\text { titanate sand } \\
\text { metallic iron }\end{array}$} \\
\hline & $1500-1800^{\circ} \mathrm{C}$ & Atmosphere & & -RED & OX/RED & OX/RED & \\
\hline & & Melt & & OX/RED & OX/RED & OX/RED & \\
\hline & & Refractory & & WC Skull & WC Skull & WC Skull & \\
\hline \multirow{3}{*}{\multicolumn{2}{|c|}{$\begin{array}{l}\text { ASG = aluminosilicate glass } \\
\text { BSG = borosilicate glass } \\
\text { G-C = glass-ceramics }\end{array}$}} & \multicolumn{3}{|c|}{ IEB = iron-enriched basalt } & \multicolumn{2}{|c|}{$\mathrm{OX}=$ Oxidizing conditions } & \\
\hline & & \multicolumn{3}{|c|}{ IEB4 = IEB + Group IV elements } & \multicolumn{2}{|c|}{ RED $=$ reducing conditions } & \\
\hline & & \multicolumn{3}{|c|}{$S Y N R O C=Z r, T i$ (not Si) based ceramic } & \multicolumn{2}{|c|}{ WC $=$ water cooled } & \\
\hline
\end{tabular}

\subsubsection{Slag Chemistry and Control of HVPM}

The slag chemistry process (materials, compositions, temperature, time, mixing) is the most important part of the melter operation because it deals directly with the production of the final waste form material and its performance characteristics. There are several important.parameters to be considered in the fabrication of an acceptable high-integrity final waste form, one is the retention of the high vapor pressure metals (HVPM). Volatilization of HVPM from the melt depends on the redox state, the temperature of the melt, and the physical operation of the melter. It may be desirable that the volatilization of the HVPMs in the melter be minimized even at high temperatures to reduce the amounts of secondary waste streams, and reduce potential maintenance problems of downstream components. Tailoring the slag chemistry to produce high temperature ceramic phases that will retain an acceptable fraction of these species, such as $\mathrm{Pb}$, $\mathrm{Zn}, \mathrm{Cd}$, etc., in stable compounds or solid solutions is highly desirable. The offgas system must ultimately be designed to trap and remove offgas transported HVPMs to meet strict emission limits.

\subsubsection{Vitrification/Devitrification Processes}

Controlled cooling allows manipulation of the vitrification and devitrification processes in the slag to produce desirable ceramic phases with an engineered grain size. Controlled cooling processes have been shown in INEL IEB research to produce a final waste form with much superior product performance characteristics. The procedures and recrystallization temperatures depend on composition and the redox state in the slag. 


\subsection{Melter-Based Thermal Treatment Systems Background}

Figure 5-4 indicates potential thermal treatment processing methods for the major buried waste categories, and is based on conceptual work performed in 1991 for remediation of INEL buried waste. The buried waste materials are very similar to the stored waste, except that they have lesser amounts of soil.

In this flow diagram, each waste category is treated separately. The nitrates may require low-temperature pretreatment to convert to oxides and $\mathrm{NO}_{\mathrm{x}}$ or blended incrementally to other wastestreams. The miscellaneous and cemented organics may need to be processed in a crusher or shredder prior to thermal treatment. Ash is recycled to the silicate melter through one of the other pretreatment processors. Additional soil may be added as needed.

Treatment for the hydrated metal oxides, construction materials (bricks, concrete, asbestos), bases $(\mathrm{NaOH})$, and acids $(\mathrm{HCl}, \mathrm{HF})$ includes similar pretreatment and melting. Other inorganic wastes could be added to one of these streams. The halogen salts could probably be added to one of these streams or to a combustible stream if strong reaction effects are expected. Mixing with soil could probably be done sequentially in the size reduction unit or while feeding the melter. Additional soil could be added as needed to give the appropriate melt composition.

The metallic wastes could be processed by a metals melter.

Several melters are shown in this conceptual waste stream analysis. Each melter system shown would be designed and operated to separately process silicate materials, metal compounds, and elemental metals. Melters can, therefore, perform different functions at different temperatures and operating conditions.

Using a single melter that is designed and operated to process all of the potential different waste types can reduce the number of melters from three to one and significantly simplify the treatment process. Figure 5-5 illustrates three basic types of melters. In a melter, there are two separate regions that influence operation, the gas phase above the melt and the molten bath. The molten bath may be composed of a molten slag floating on top of a denser liquid metal melt. Solid metals may sink to the bottom of the melter if the melting time or temperature are insufficient to melt the typically higher meiting point metals.

Actual melter designs run the spectrum from low-temperature, pure Joule-heated melters (see Figure 5-5a) through transferred arc-heated melters, with Joule, radiative, and arc-melt interface heating contributions (see Figure 5-5b) up to nontransferred-arc torches for plasma-convective heating (Figure 5-5c). Figure 5-6 shows a cut away view of one of the INEL Joule-heated melters used for IEB research. Figure 5-7 illustrates the difference between transferred arc and nontransferred arc modes of operation for a plasma torch. Figure 5-8 illustrates a cross section of a Retech plasma centrifugal reactor. This plasma melter uses a transferred arc torch with an oxygen lance for combustion inside the chamber. The slag is poured out the bottom by slowing the speed of rotation. 


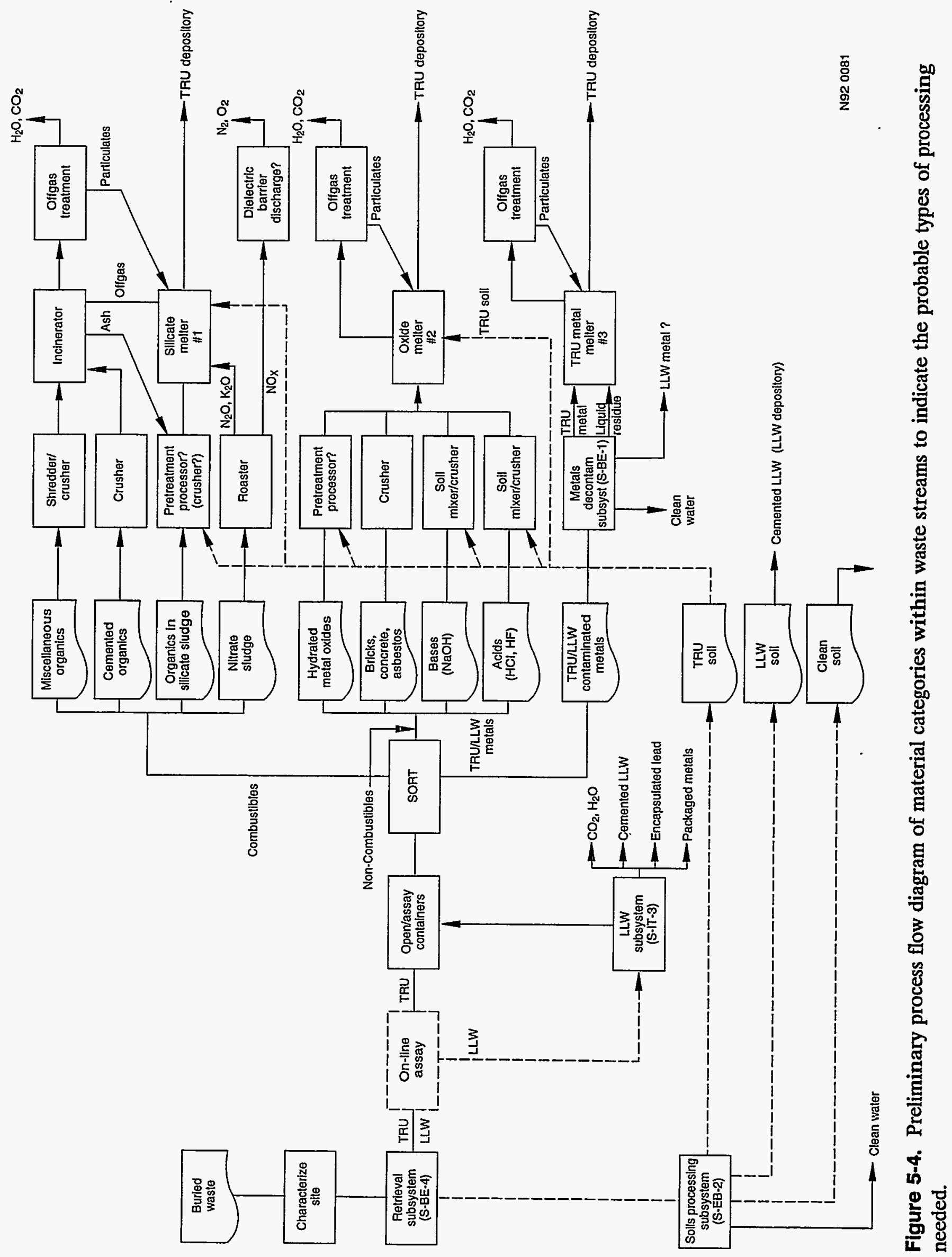




\section{Plasma Heated Melter} (Nontransferred)

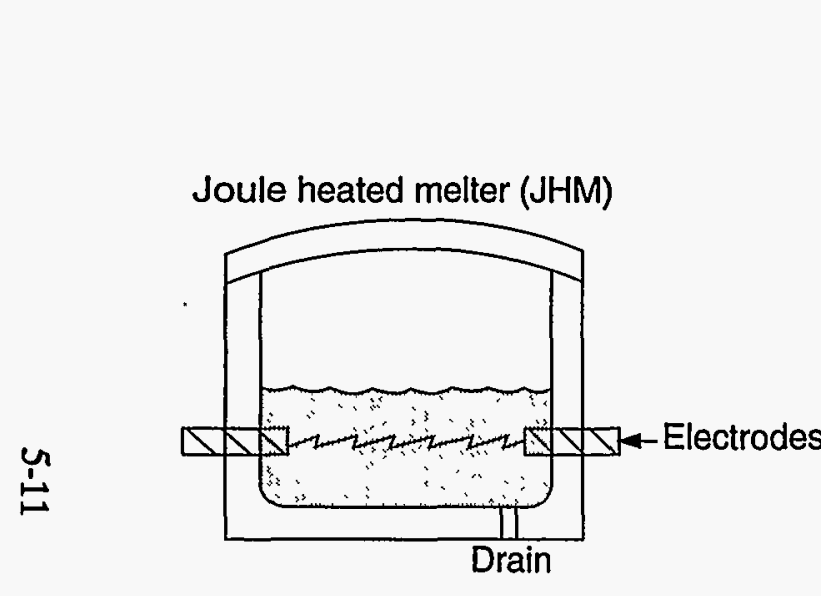

(a)

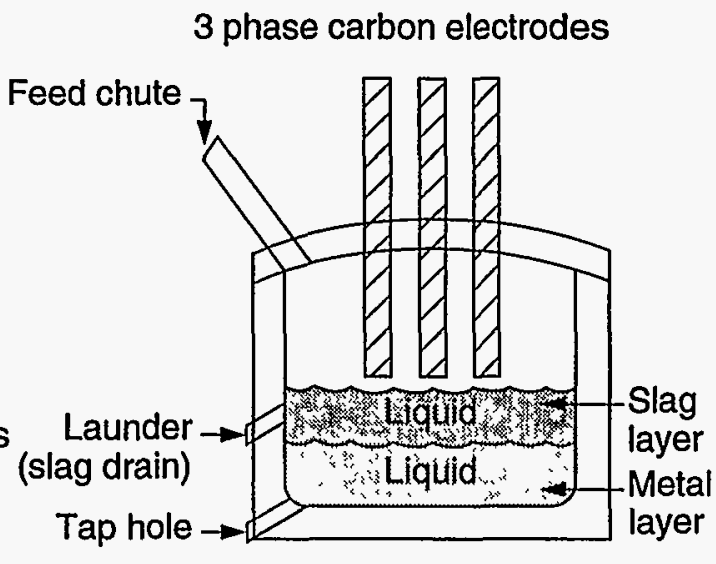

(b)

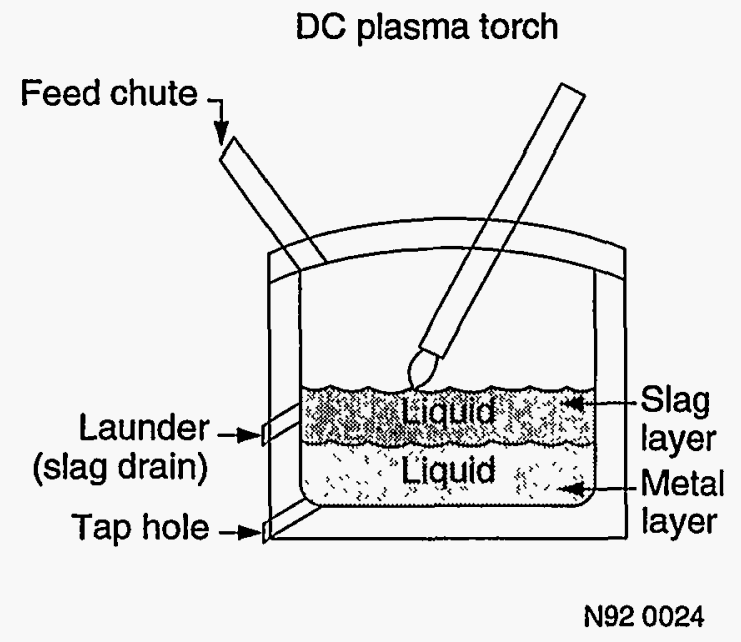

(c)

Figure 5-5. Conceptual sketch of electrically heated melters: (a) Joule-heated melter with the immersed electrodes in the horizontal configuration, (b) an arc-heated melter with 3-phase ac operation and graphite electrodes, and (c) a plasma-heated melter with 1-phase dc operation and both electrodes in the torch. 


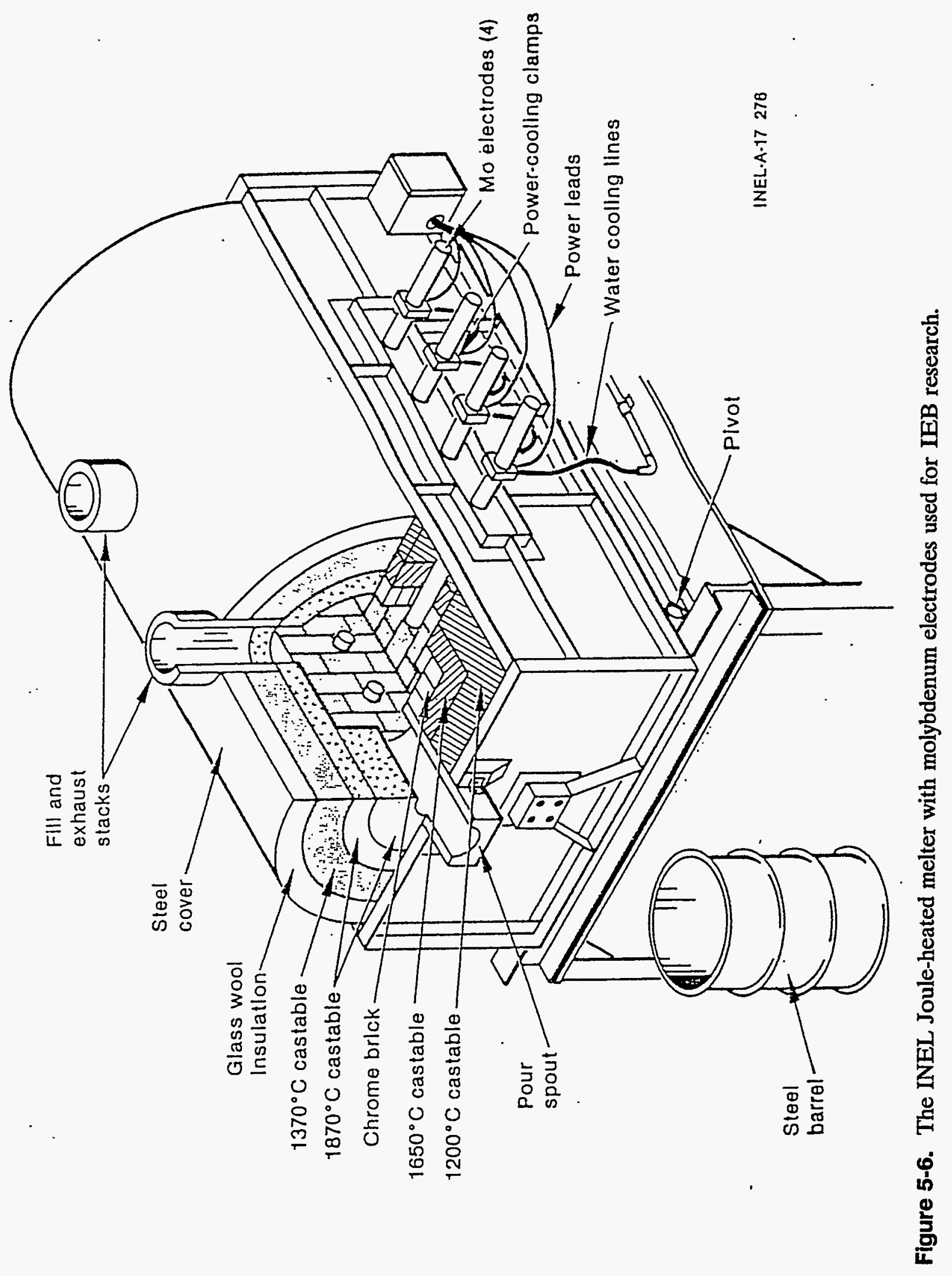


Plasma torch types

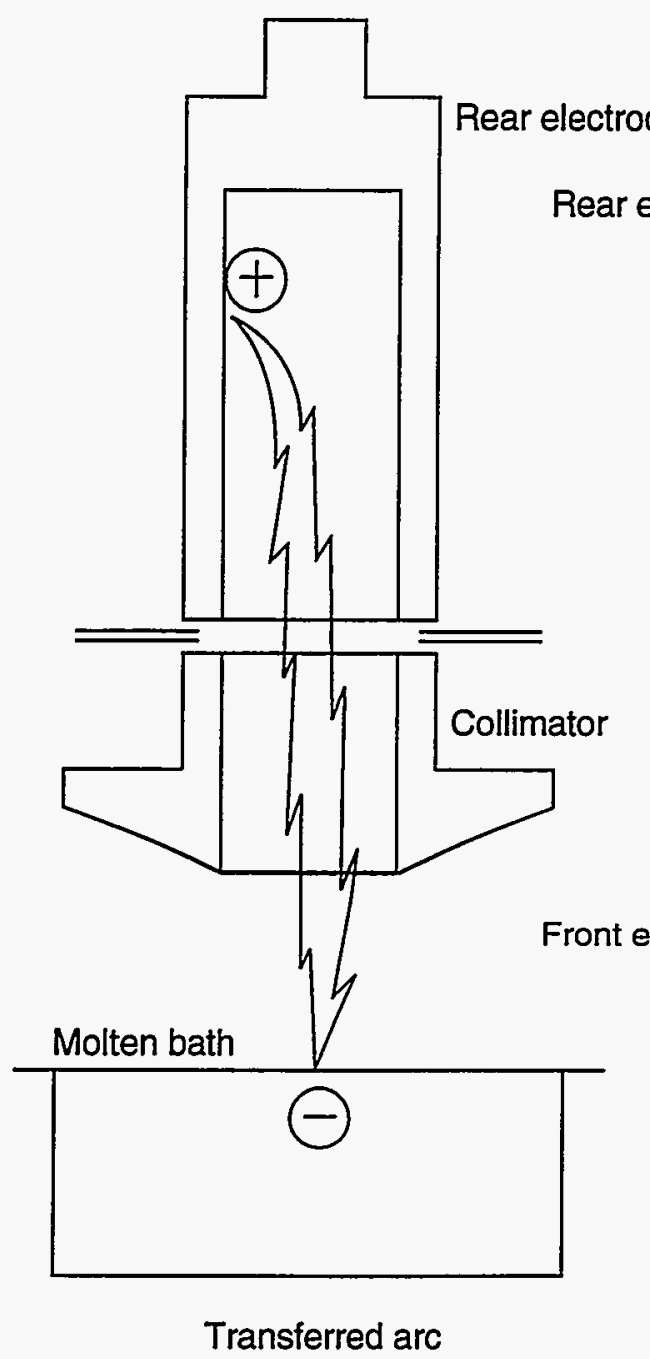

(a)

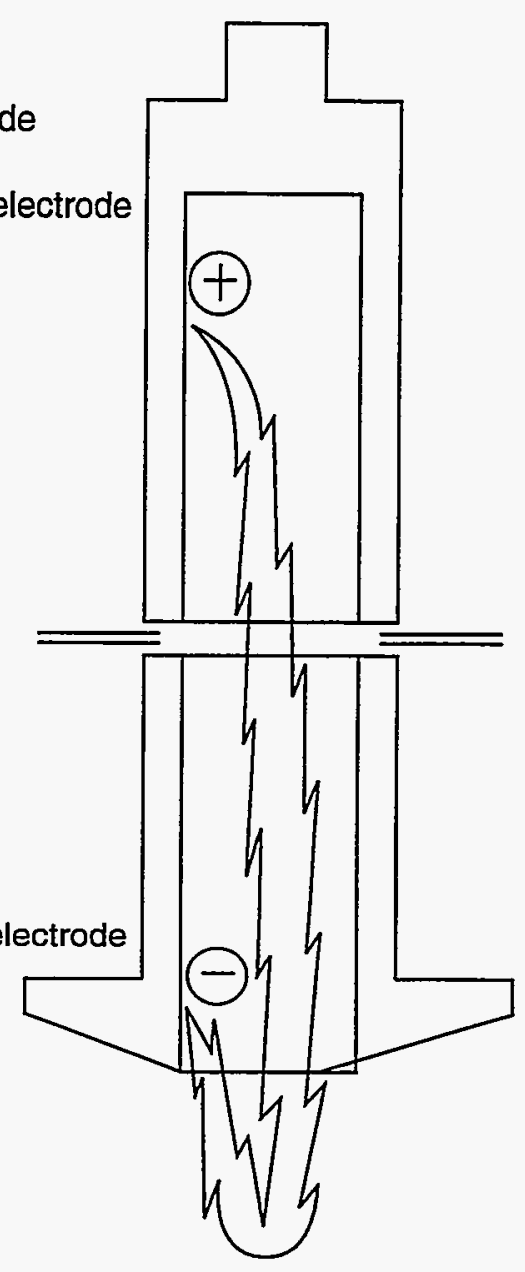

Non-Transferred arc

(b) $\quad$ N91 0161

Figure 5-7. Plasma-heated melter torch-electrode configurations: (a) transferred-arc torch with the melt as the cathode and (b) nontransferred-arc torch with both electrodes in the torch.

Low-temperature melters $\left(900-1200^{\circ} \mathrm{C}\right)$ can melt glasses and assimilate waste streams that are not high in metals content, especially aluminum and iron, and that are not high in metal oxides or soils with high alumina (alumina-silicates, basalts) or titania/zirconia (e.g., Synroc). These melters are usually termed glass melters. Refractory-lined, Joule-heated melters with inconel electrodes using a borosilicate glass frit for assimilation of a relatively homogeneous waste stream is one example of a low-temperature (glass) melter. Almost any melter can operate under low temperature melter conditions. 


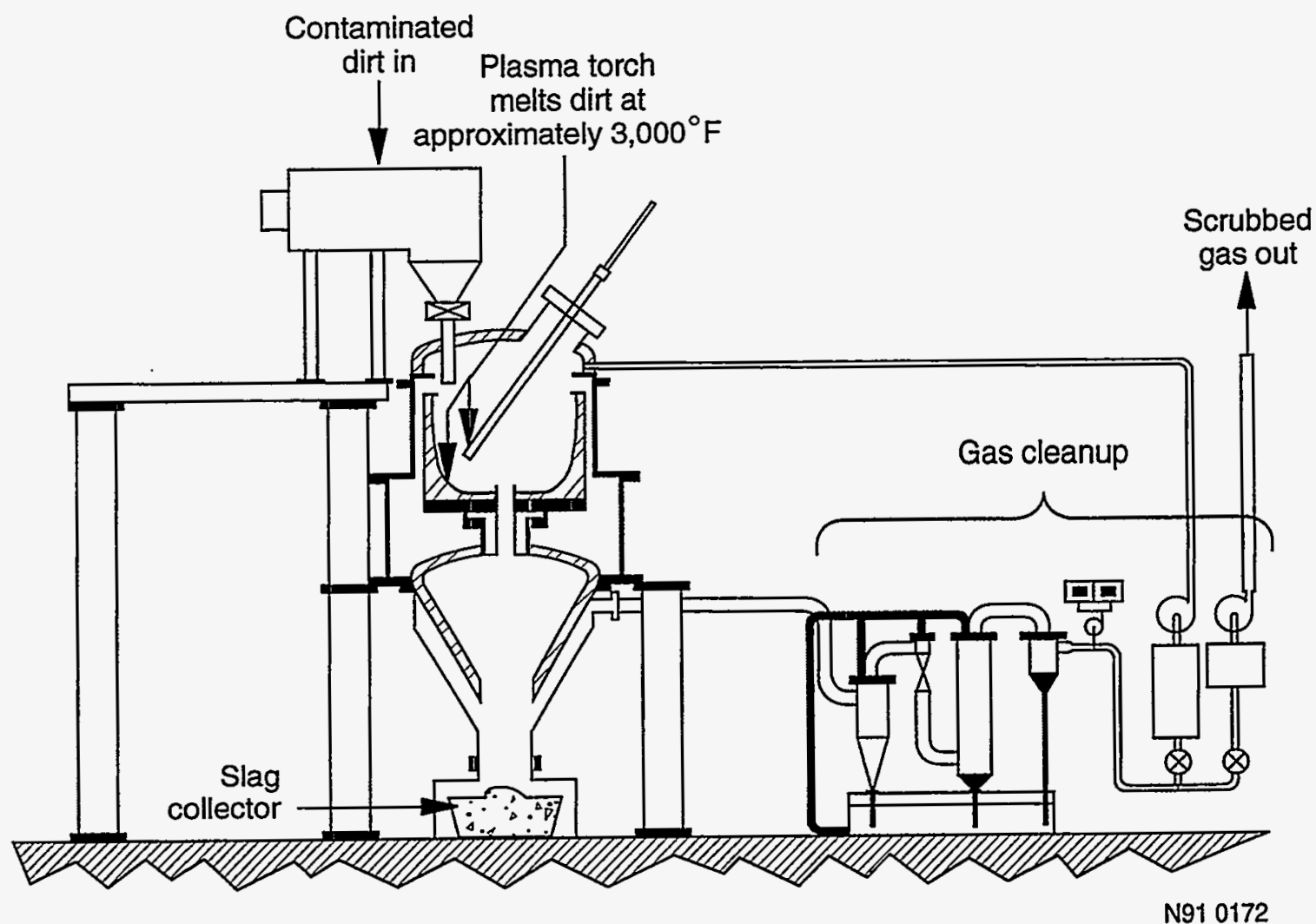

Figure 5-8. Plasma-heated melter used in the INEL PAFE experiment in the transferred-arc mode with 1-phase dc operation, metal electrode torch, an oxygen lance, and water-cooled skull with a rotating chamber that is slowed to pour the slag.

Medium-temperature melters $\left(1200-1500^{\circ} \mathrm{C}\right)$ can usually melt various glasses, glass/ceramics and soils. A Ruby-refractory lined, Joule-heated melter with molybdenum electrodes is an example of a low-maintenance, medium-temperature melter. High-temperature melters $\left(1500-1700^{\circ} \mathrm{C}\right)$ are capable of melting most ceramics and metals, including iron, basaltic soils, and high-temperature ceramics. Present Joule-heated melter electrodes will melt or rapidly corrode under these conditions because of the locally higher temperature at the electrode.

Arc- or plasma-heated melters with transferred or nontransferred (arc to slag/melt) operation are capable of providing the intense heat source required without excessive electrode corrosion because the electrodes do not contact the melt or are of much higher temperature materials (e.g., graphite). Refractory corrosion can be reduced by using a water-cooled skull of the slag material between melt and melter wall, while maintaining temperature with the intense heat source. Maintenance is related to graphite electrode consumption and replacement rates or to plasma torch electrode lifetimes.

The oxygen stoichiometry or redox (reducing or oxidizing) condition in the slag and in the melter gas phase is a critical operating condition. Melters may operate with reducing conditions in the slag and in the gas, with subsequent oxidation in an afterburner. Oxidizing melters may be substituted for combined melter and incinerator units. Oxidizing-slag melters may also be designed to oxidize all metals, eliminating the metal product. Metal tapping melters allow the 
draining of liquid metal from the bottom of the metal melt, as well as slag from above it. Low-temperature Joule-heated melters with inconel electrodes work well under oxidizing or reducing conditions in the melt/slag or gas phases. A medium-temperature Joule-heated melter with molybdenum electrodes will corrode rapidly under high temperature oxidizing conditions, but it can work satisfactorily under reducing conditions.

For arc melters, the use of graphite electrodes is acceptable for reducing or neutral conditions. If the gas phase is oxidizing, the carbon will oxidize to $\mathrm{CO}$ and $\mathrm{CO}_{2}$. Coating the electrode with $\mathrm{SiC}$ or a similar substance has been shown to reduce the graphite oxidation. Flooding the electrode tip with argon can reduce oxidation of the tip.

The allowed redox state for a plasma/arc melter with water-cooled metal electrodes can be more oxidizing than for the graphite-electrode transferred-arc melter. Both oxidizing and reducing states in either gas or melt phases are possible. With a plasma nontransferred torch, the plasma gas could be blown into the melt like an air or oxygen lance. The maintenance requirements of plasma torch electrodes are higher than for consumable graphite electrodes. The latter adds carbon to the melt, which will change the redox state and may diminish the quality of the waste form. In other plasma systems, electrode alloys have been developed to work in oxygen-rich environments (e.g., $\mathrm{TiO}_{2}$ production).

The degree to which one basic melter system can be designed and operated to accommodate the variations in input stream characteristics and still produce an acceptable final waste form is the current focus for this system development effort.

\subsection{Review Meeting Considerations for a Melter-Based Thermal Treatment System}

\subsubsection{Review Meeting Focus}

The technical review was divided into three major technical focus areas for operating a melter-based thermal treatment system for radioactive and hazardous mixed waste-primarily the melter, offgas control system, and overall system considerations.

To maintain focus on the above areas and keep the review meeting to a reasonable length, several issues were not included in great detail. The review meeting did not cover the following:

- System front end characterization and pretreatment. These two areas are recognized as being very important; however, they are considered secondary in the design process for the actual melter-based treatment system. The limits of operation of the melter will influence the requirements of the front end characterization and pretreatment.

- New, emerging thermal treatment processes. The review meeting focused on melter designs considered industrially proven with an experience base. 
- Processes with complex reactions requiring sensitive, fine monitoring, and control. If a simple process can do the job, there is no need to venture into processes with complex reactions.

- Final waste form development. This subject could easily require many days of review Background information is given in the preceding discussions and a more detailed discussion is presented by Eddy, Kong, and Raivo (1992). The glass-ceramic basalt-based waste form has been chosen as the primary produced waste form for which the melter system is to be designed around. It is recognized that secondary and possibly tertiary wastes forms will also be produced.

- Waste form size and packaging. These two areas are also recognized as being very important; however, they are considered secondary in the design process for the actual melter-based treatment system and not within the scope of the review meeting.

The primary focus was on the melter itself, the limits of operation, the limits of configuration, and the limits of inputs and outputs into and from the melter. The main issues to be resolved in the review meeting were as follows:

- Robust feeding or detailed sorting: Based on the collective experience base of melter experts, what sorting and pretreatment considerations are necessary?

- Combustion prior to or within the melter: A thermally based pretreatment step prior to the melter would decrease the variations in the melter input feed, but is it necessary?

- Sizing to minimize volatility or fuming: What are the particle size effects on volatility?

- Plasma torch or graphite electrodes: Either represents a means for the addition of heat energy to enable the production of the final waste forms. What are the advantages and disadvantages of each?

- Long arc or short arc: What are the advantages and disadvantages of each?

- Rotating or stationary chambers.

- Oxidizing or reducing environment.

- Primary, secondary, tertiary waste forms.

Primary focus melter issues are discussed in more detail in Section 6. The offgas system, is discussed in more detail in Section 7.

The melter considerations and offgas considerations necessarily must be discussed in the context of the complete system and facility. An abbreviated list of these issues are as follows: 
- Heterogeneous input feed streams. The feed streams input into the system have greatly varying compositions, and particle sizing, with mixes containing various metals, including toxic metals

- Radioactive waste treatment: The waste streams are contaminated with radioactive isotopes, primarily alpha emitting isotopes, with possibly some beta/gamma-emitting isotopes.

- $\quad$ EPA hazardous waste treatment: The waste streams are contaminated with EPA-regulated hazardous constituents, including RCRA Characteristic and Listed wastes (solvents, HVPM metals) and TSCA wastes (PCBs, minor).

- Level of confinement required: Double, or triple confinement, will be necessary primarily due to the radioactive alpha contamination present.

- Safety of operations. For this program, a production facility would be a DOE-governed facility that would invoke many safety-related issues, including Safety analysis and operational limits.

- Facility classification. Design and operations must include accident prevention and mitigation, safe shutdown philosophy (normal or accident), and natural disaster criteria.

\subsubsection{Melter-Based System Conceptual Requirements}

For brevity, an abbreviated list of conceptual requirements for the melter was used at the review meeting. These are listed below.

Input

- Heterogeneous wastestream, with variations designated as G1 (glass), M1 (metals), C5 (combustibles), $\mathbf{P}$ (portland cemented organics), S (silicated organics), HD1 (hydrated metal oxides), Nom-60 (synthesized test case wastestream for the U.S. Bureau of Mines tests with $60 \%$ nominal INEL soil)

- Soil as needed (40 wt\% design-base case)

- $\quad$ Fluxing agents if required

- Oxygen gas or air as required to maintain oxygen levels in the melter

Functional Requirements

- Organic compounds and immobilize toxic metals and fines

- Destroy or chemically fix EPA hazardous compounds

- Immobilize radionuclides 
- Tap molten basaltic (glass-ceramic) melt

- Melt and tap metals

Operational Requirements

- Nominal operating temperature $>1600^{\circ} \mathrm{C}$

- Throughput of approximately one metric ton per hour (2200 $\mathrm{lb} / \mathrm{hr}$ based on 10 -year operations)

- Basaltic melt at adequate pour viscosity

- Uptime of 24 hours per day when running, at $50-90 \%$ per year total up time (70\% per year nominal)

- Operations conducted safely according to OSHA, NRC, DOE, State, and local regulations.

\section{Output}

- Variable volume rate offgas (cubic feet per minute)

- Molten basalt output (glass-ceramic)

- $\quad$ Molten metal

\subsubsection{Melter-Based System General Design Requirements}

An abbreviated list of general conceptual design requirements for the melter and system was used at the review meeting. These are listed below.

- Keep it simple. Equipment and processes that will enable robust treatment operations with wide limits of operation (tolerance bands) will decrease the overall complexity of the system. The basis is that any problem associated with extra complexity is greatly compounded with a radioactive or hazardous operation.

- Keep it safe. The treatment facility and operations must maintain the safety of operating personnel, the public, and the environment.

- The treatment process must

- $\quad$ Satisfy EPA and DOE requirements

- Maximize the volume reduction of the input waste (the underlying assumption is that disposal costs are based on volume and are very high for this type of waste) 
- Maximize the quality of the final waste form(s)

- Increase the ability to perform radiological assays and increase the credibility of results of radiological assays

- Minimize the primary zone footprint $\left(\mathrm{ft}^{2}\right)$ and volume $\left(\mathrm{ft}^{3}\right)$ to the extent practical, while still maintaining sufficient space for operations and maintenance (primary zone costs associated with construction, operations, maintenance, and decontamination and decommissioning are very high).

\subsection{Melter Based Thermal Treatment System Scenarios}

Two melter based thermal treatment system flowcharts were presented for review by the advisory committee. The two flowcharts are very similar except for the inclusion of a thermal pretreatment step in the first scenario. The base case flowchart is the melter with a thermal pretreatment step (desorber/incinerator). This case is considered and presented as the more conservative case for the successful operation of the melter. Adding the thermal pretreatment step will make the operation of the melter less difficult; however, it will increase the complexity of the total system. The offgas system flowchart presented is identical for the two.

The waste series designated for preliminary studies include $\mathrm{G} 1, \mathrm{M} 1, \mathrm{C} 5, \mathrm{P}, \mathrm{S}, \mathrm{HD} 1$, and Nom-60. The compositions of these waste streams were shown in Section 4.

Figure 5-9 presents the baseline system scenario. In this scenario, the waste is assumed to first go through an initial retrieval, initial radioactive assay, and initial gross sorting step. For INEL waste, this step would be similar to the steps involved in processing the waste through a facility similar to the Stored Waste Examination Pilot Plant facility to identify special case wastes. The primary purpose of the initial sort is to remove special case waste to enable bulk materials processing without problem wastes. The anticipated classification of special case wastes include large machines and equipment, containers with large amounts of lead, known mercury vials, and highly radioactive items. The goal for the treatment train is to routinely treat the containers and waste without opening and detailed sorting if it is judged not special. The issue is what level of sorting up front is required. The current designs indicate that gross sorting is adequate.

Special case waste would be sorted out and sent through special sorting and size reduction steps, possibly returning to the treatment line. The mainstream wastes would enter one or more size reduction steps to enable processing in a thermal pretreatment step (e.g., a desorber/incinerator) and enable better monitoring of the waste for safety and process control. Equipment would include one or more low-speed shredders, crushers, or shears capable of processed material output in the two- to four-inch (2-4-in.) range. Larger sizes may be compatible, depending on limits for downstream components.

Size reduction is followed by a monitoring step. The monitoring step would provide higher quality information than previously available because of the size reduction. Monitoring can be by visual observation, continuous monitors, or batch type monitoring equipment. Compositional 
가 Lockheed

Idaho Technologles Company

Xulaho Waste Treatment Pregrnm:- Preliminary Design January 30, 1995

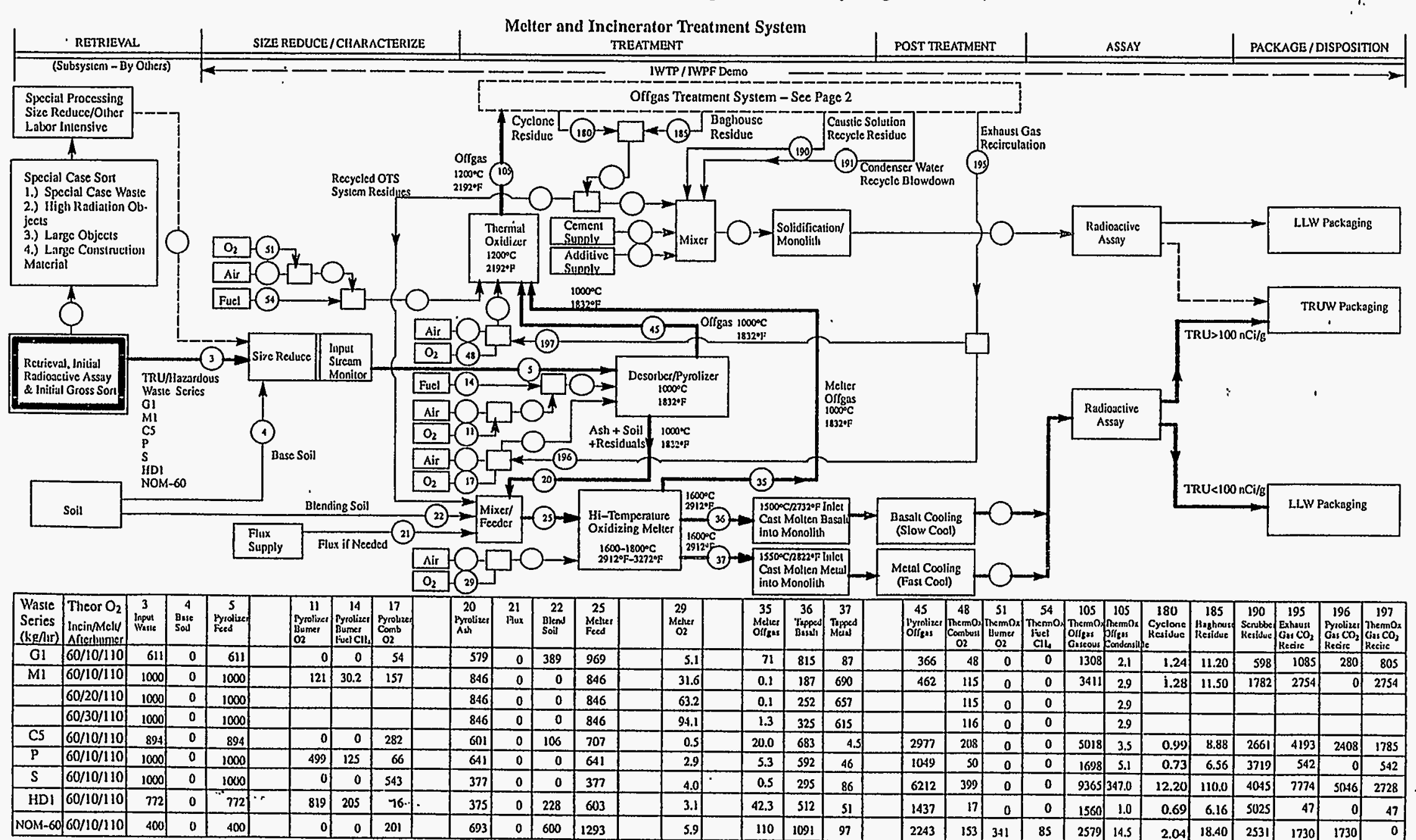

Figure 5-9. AdvMWTP melter and incinerator system flowsheet. 
classifications of the wastes into the $\mathrm{G}$ (high inert glass), M (high metal), C (high combustible), $\mathrm{P}$ (high hydrocarbons, some chlorides), S (high hydrocarbons, high chlorides), H (high hydrates), or $\mathbf{N}$ (high alkali nitrates) and quantitative values can be assigned at this point. For process control, this monitoring step would enable data manipulation to vary the soil input, or vary other input waste stream feed rates to the thermal pretreatment unit or the melter to maintain compositional range of the final output product.

These retrieval, size-reduction and monitoring steps were not considered in great detail at the review. The primary purpose of the review meeting was to consider potential design variations and limits of operation of the melter itself, whether pretreatment is needed and impacts on the offgas system. The melter is the heart of the system, and recommended design of it will affect both upstream and downstream system design.

In the baseline case, the waste leaves the monitoring station and is processed through a thermal pretreatment step (a desorber/incinerator) to perform initial combustion, thereby reducing the volume and lessening the variations in waste feed prior to entering the melter. A separate thermal pretreatment unit is presented as the baseline design case to establish a conservative design approach. Primary functions are to enhance temperature control, desorption of carbonates, hydrates and nitrates, and enhance chloride, volatile metal, and hydrocarbon (soot) control. Potential types of equipment to accomplish this step include a rotary kiln, molten salt oxidation unit, fluidized bed, controlled air furnace, and shaft furnace. Baseline conditions are $1000^{\circ} \mathrm{C}\left(1830^{\circ} \mathrm{F}\right)$ in a starved air mode to minimize offgas and hold HVPMs and radionuclides in the residue to the maximum extent. The present baseline scenario anticipates a rotary kiln operated with controlled air combustion. Several issues arise with this arrangement, which include control of infiltration air and seal reliability for the rotary kiln. Other considerations for a thermal pretreatment unit include maintenance of refractories, effects of chlorine and sulfur on the equipment, control and monitoring, air versus enriched air versus straight $\mathrm{O}_{2}$ operation, and optimum feed sizing. Table 5-2 presents a comparative overview of the $\mathrm{O}_{2}$ enrichment options for a pretreatment unit.

Due to the large variations in the input feed streams, initial calculations show the need to control temperature on the unit. Some feeds may have too much fuel available, others may not have enough to maintain temperature. For the cases where not enough fuel is available, auxiliary fuel firing will be necessary. When too much fuel is available in the input wastestream, a process to reduce the temperature is required to maintain operating conditions. The baseline case uses exhaust gas recirculation (EGR) to accomplish this temperature control. The advantages from using EGR include less flowrates (higher specific heat capability of $\mathrm{CO}_{2}$ ), reduction of $\mathrm{N}_{2}$ in the offgas systems, and the presence of a smaller offgas system. The disadvantages from using EGR include some water vapor in the EGR, potential for contamination of the EGR systems, and EGR is not available at startup (requires starting on air or stored $\mathrm{CO}_{2}$ ).

Alternatively, an air-based system could be used to accomplish temperature control. The advantages are that air is readily available without adding system complexity, and it is available at startup. Due to the lower specific heat capacity of air, a higher flowrate is needed than for a $\mathrm{CO}_{2} / \mathrm{EGR}$ system. This results in a larger system, which increases the flowrates of the total system. 
Table 5-2. Thermal desorber/pyrolyzer oxidant.

\begin{tabular}{llll}
\hline \multicolumn{1}{c}{ Factor } & \multicolumn{1}{c}{ Oxygen } & Oxygen enriched air & \multicolumn{1}{c}{ Air } \\
\hline Exhaust gas composition & $\mathrm{CO}_{2}, \mathrm{H}_{2} \mathrm{O}$ & $\mathrm{CO}_{2}, \mathrm{~N}_{2}, \mathrm{H}_{2} \mathrm{O}$ & $\mathrm{CO}_{2}, \mathrm{~N}_{2}, \mathrm{H}_{2} \mathrm{O}$ \\
Offgas flow rate & Smallest & Medium & Largest \\
Offgas system size & Smallest & Medium & Largest \\
Temperature & Highest & Medium & Lowest \\
Auxiliary fuel/oxidant & Lowest & Medium & Highest \\
required & & & \\
Additional gas for control & Highest & Medium & Lowest \\
Safety & Lowest & Medium & Highest \\
\hline
\end{tabular}
system.

Offgas from the thermal pretreatment step is sent to an afterburner and to the offgas

The ash and residue from the desorber/incinerator goes to a mixer where soil and flux, if needed, is mixed and fed into the melter. Holdup surge and inventory considerations for the ash and residue from the thermal pretreatment step are not shown on the flowsheet; however, these may be necessary to maintain throughput within operating limits. Methods include close coupled direct feed, coupled-to-hopper feed (2-3 hoppers) or separate storage bins. The baseline scenario includes surge control to the extent of coupling to the feed with two hoppers at the mixer/feeder to the melter. The purpose of the mixer/feeder is to facilitate material transfer from the desorber/incinerator to the melter, blend in soil and flux if needed, and feed the melter. An issue arises for this scenario for the handling of hot ash/residue at the output temperature of the thermal pre-treatment unit $\left(1000^{\circ} \mathrm{C}\right)$. Handling of this hot ash/residue presents design and equipment maintenance problems that further complicate the design and operation of the total system. An ash/residue cooling process may be required.

From the mixer, the waste, soil, and flux, if required, are fed into the melter. The purpose of the melter is to enable casting of a homogeneous glass/ceramic product, and melt, tap, or oxidize metals. The design temperature of the melter is high enough $\left(1600-1800^{\circ} \mathrm{C}\right)$ to melt the soil and the metals contained in the input feed. Baseline conditions are to operate with a cold cap to reduce HVPM volatization and minimize gas temperatures. Issues for this unit are (a) maximum particle size of the feed, (b) batch versus semibatch versus continuous operation, (c) graphite electrodes versus plasma torches, (d) power consumption, (e) thickness of the cold cap, and $(f)$ maintenance operations verses unit replacement. Detailed description of the melter design and operation issues are presented in Section 6.

Offgas from the melter also goes to the afterburner. For this scenario, both the offgas from the thermal pretreatment step and the melter go to a single oxidizer. Actual design may dictate separate systems for these two offgas streams due to the large differences in flowrate and composition. The design team proposes separate systems, whereas the flowsheets show a common 
system. The purpose of the afterburner is to ensure destruction efficiency for hazardous constituents. Baseline operating conditions are $1200^{\circ} \mathrm{C}\left(2192^{\circ} \mathrm{F}\right)$ for a minimum of 2 seconds residence time. The use of air verses $\mathrm{O}_{2}$ enriched air verses straight $\mathrm{O}_{2}$ similar to the incinerator is also an issue for the afterburner. The baseline scenario uses straight oxygen. The auxiliary fuel and EGR are included in the afterburner design to maintain the design operating temperature. The heating value of the offgas will vary widely for different waste feeds.

The melter has the capability to tap both molten basalt and molten metal streams. These molten streams are sent to casting operations where final form monoliths are produced. The purpose of the casting step is to cast an optimum shape for radiological assay and disposal. Casting size options include frit, small to medium shaped cast monoliths, and large cast monoliths (e.g., barrels or cubes). These monoliths may undergo a posttreatment cooling (devitrification) phase to enhance phase structure and material properties. As stated, the casting and cooling operations are not considered in the technical review. These issues are considered secondary to the main issues of the review meeting.

Figure 5-10 presents the alternative scenario, where the desorber/pyrolyzer is eliminated. The melter must be capable of receiving and processing the wastes without prior thermal treatment. Though this scenario complicates the design and operation of the melter, it greatly simplifies the design and operation of the total system due to the complete elimination of the thermal pretreatment step. More detailed issues associated with this approach are presented in Sections 6 and 7, with summaries presented in Section 8.

All offgas from either the baseline scenario or the alternate scenario is processed through an afterburner to ensure complete destruction of entrained waste constituents and then sent to the offgas cleaning system. Figure 5-11 presents the baseline offgas handling system. Detailed discussion of issues associated with the offgas system is presented in Section 7.

The waste forms (primary basaltic, metal, and secondary or tertiary) are processed through radiological assay stations to identify and quantify radionuclides present, enabling decisions for final disposal to be made based on the best available data and information. Figure 5-12 presents a simple overview of the issues involved with assay of alpha-emitting waste and the increase in credibility of data obtained from thermal treatment of the initial stored state, through partial treatment and ending with the produced primary waste form.

After the radiological assay, the final waste forms are packed, marked, labeled, and transported to the designated disposal site. The final step in the waste treatment and disposition scenario is to assess the waste form in the disposal site. The act of high-temperature thermal treatment and the production of the basaltic waste forms enhance the performance of the waste forms in the final disposal site. The basaltic glass-ceramic waste forms have analogs naturally occurring in the environment that have been in existence for millions of years. Performance assessment issues were not a part of this review meeting; however, these issues have been studied by the INEL, and indicate that the waste forms chosen for these treatment systems are the correct waste forms to be pursued. 


\section{云blockheed}

Idaho Technolog/es Company

Jdahe Wastc Treatment Program - Preliminary Design

January 30, 1995

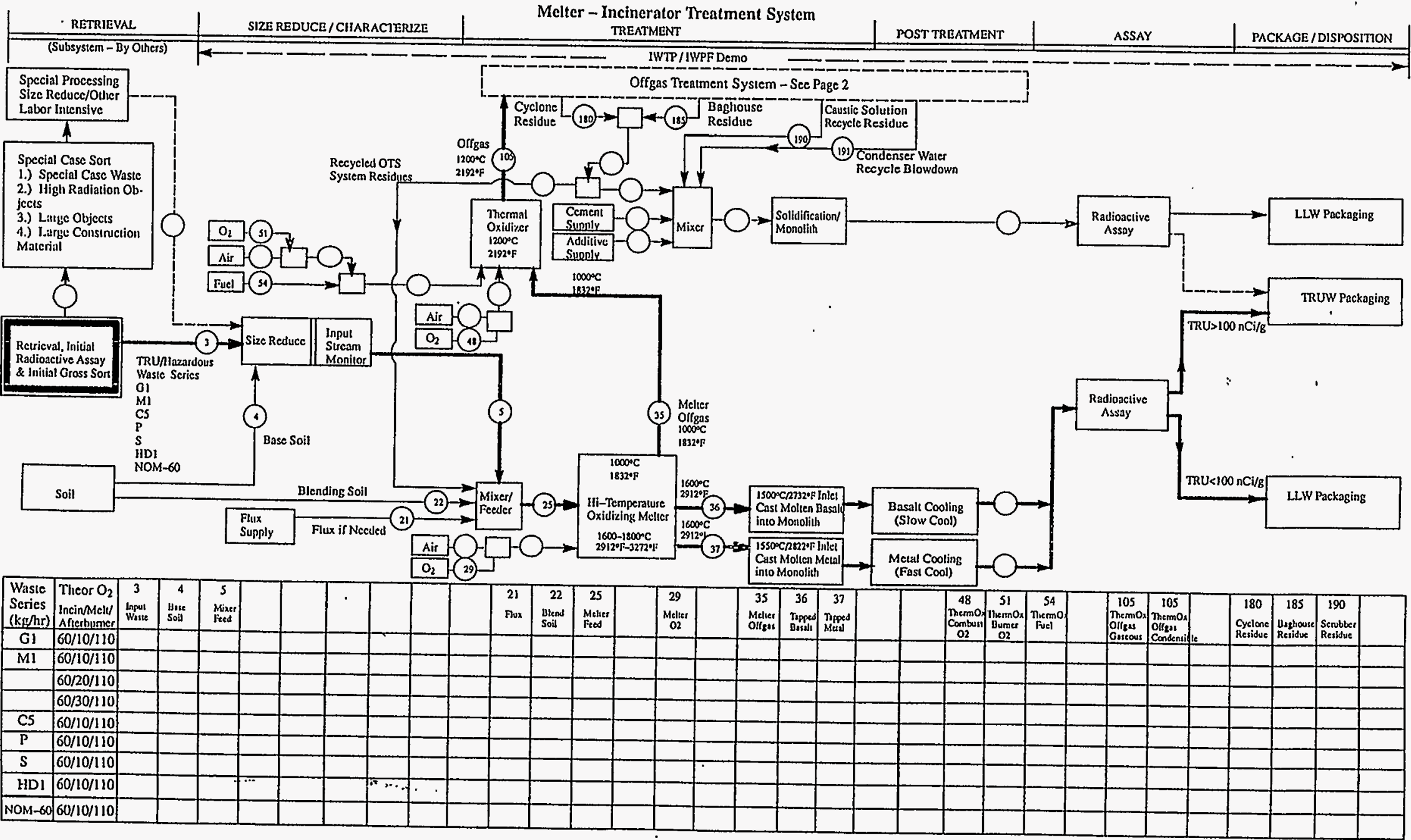

Figure 5-10. AdvMWTP combined melter/incinerator system. 


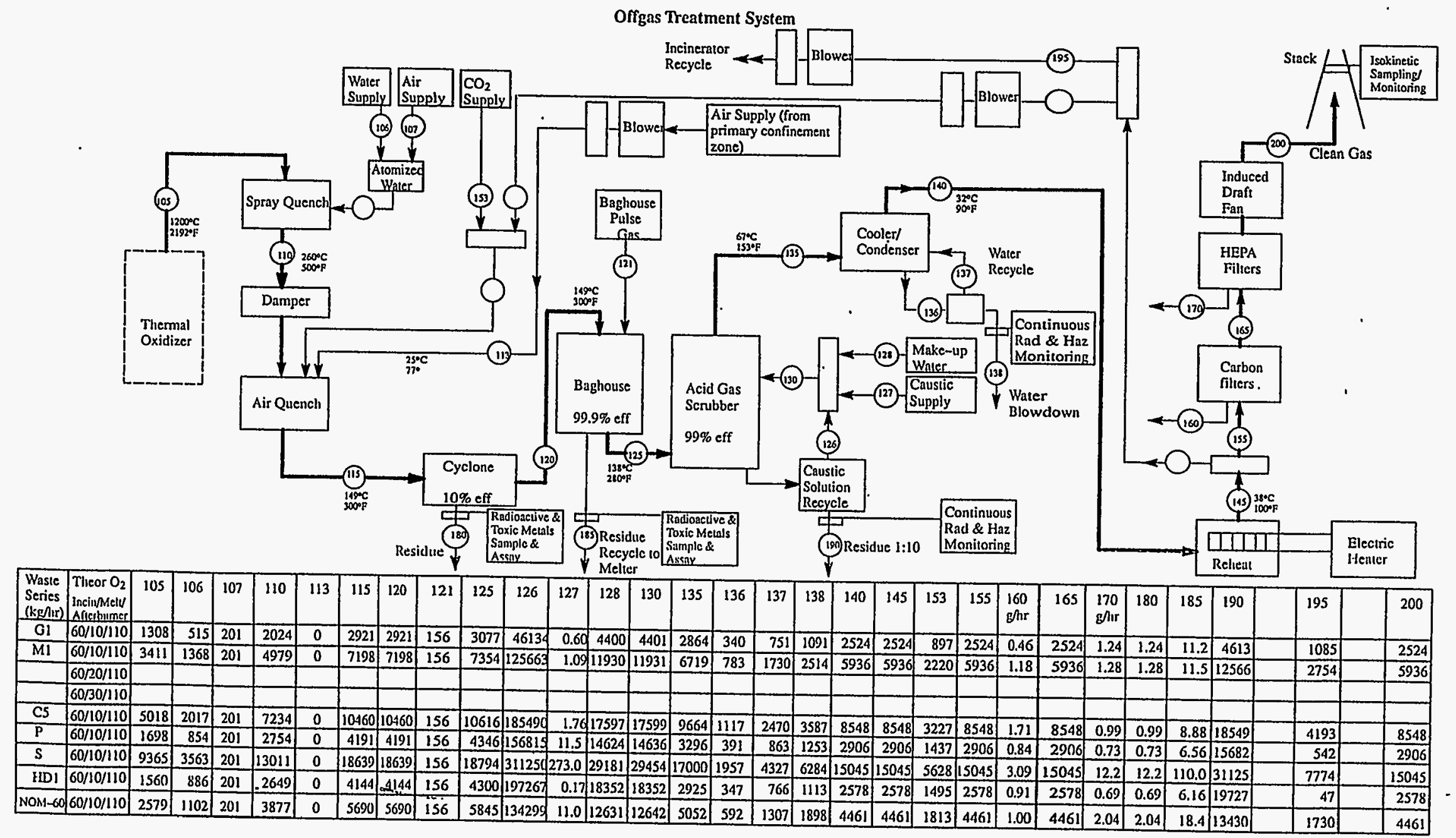

Figure 5-11. AdvMWTP Offgas Treatment System. 


\section{चरlockheed}

Idaho Technologles Company

Jdalo Waste Treatment Program - Preliminary Design October 14, 199 Assay Scenario

Assumptions: 1.) Credible assay(s) need to be performed.

2.) Combustibles will be one of the largest problems for processin

\begin{tabular}{|c|c|c|c|c|c|}
\hline RETRIEVAL & SLZE REDUCE / ASSAY & TREATMENT & ASSA & POST-TREAT & PACKAOE / DISPOSITION \\
\hline
\end{tabular}

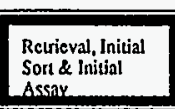

Waske. Succant: As Recricued
Mlus Soll

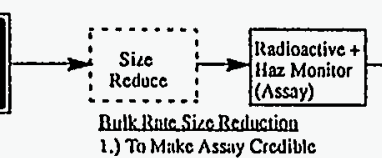

1.) To Maike Assiy Credibiol

3.) Rechdcrs Indivividual Wustec Picecs

ஸ்

Initial Assay of Waste us

- Hetcrogencous Marix

- Larye Gcomelry Variances

- Laryc Densily Variances

Variances

- Long Assay Time

\section{Assoydarer Sizc Reeluction.}

Radioaclive plus voC Assay

(Characterization) of Waste for

Processing Safcty and Quality
Cemrol of Treatmenu System Qutpur

- Reduced Helerogencily of matrix

- Reduced Geomein' Variances
- Reduced Density Variances

- Reduced Density Variances
- Reduced Radionuclide Distribution

Variances
- Reduced Self Shielding Unknowns

- Reduced Scli Shiclding Unknowns
- On-line Real time Assay-Reduced Assay
Time

$\begin{array}{ll}\text { High Unceralnty-Low Credibili- } & \text { Decreased Unceraininy- Increased } \\ \text { 1)' } & \text { Crrdibility of Assay Data at Bulk } \\ \text { of Assay Data at Bulk Proccssing } & \text { Processing Rate (Tons/day) } \\ \text { Rale (Tons/day) } & \end{array}$

个 credluilitix

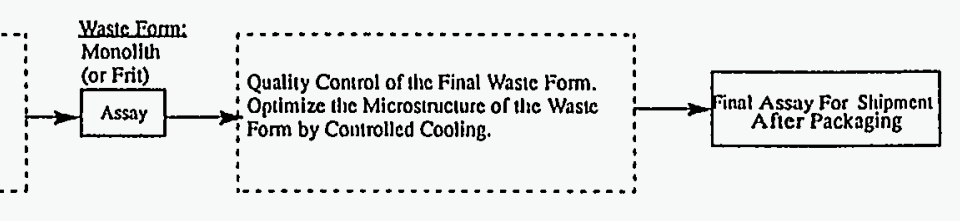

Assay Afler Thermal Trealment.

Assay in Eillter a Frit or Monolith Form

Whichever Yields the Mos! Credible Results (Greacsi Identification and Quantification or

- Fully Hlomogencous matrix (Complece

- Fully Hom

- Geometry of Choice

- No Density Variances

- No Radionuclide Distribution Variances

(Fully Dissolved Radionuclides)
- Predictable Selr Shielding Unknown

- Reduced Assay Time Duc to Known Fom

- Allows Posi Trealment Son or TRURLW

- Radionuclide Identificalion and Quantifi-

calion for Disposition decisions

Largest Decrcasc in Uncertainty - Greatest Increase in Credibillty of Assay Da
Bulk Processing Rale (Tons/day)
Assiysdier Post Trentment ond Backigiug Eer.Shipment

Final Assay of Packaged Fitul Waste Form. Natural Analog, Higls Qualily, Long Lived

- Fully Homogeneous matrix

- Known Geometry No Density Variances

No Radionuclide Distribution Variances (Fully Dissolved Radionuclides)
- Predictuble Selr Shiclding Unkno - Reduced Assay Time Due to Known Form - Allows Tor Repealability Comparisons or Data - Radionuclide Identification and Quantifi-

Higlı Credibility of Assay Dara

Increased Credibillily of assou Data Through ThecremL Processing

Figure 5-12. Thermal Treatment System radiological assay overview. 


\section{INCINERATOR AND MELTER DESIGN CONSIDERATIONS}

The purpose of this section is to identify desirable electric arc melter electrode and geometry configurations for melting solid waste into a molten basalt or slag. This section is a synopsis of work presented by Eddy and Raivo (1995). The work is a first approximation of what might be needed and serves more to eliminate the more undesirable systems than to select the preferred system. The work also identifies melter options and features, provides a weighting estimate, and obtains a preliminary evaluation of various melter designs. The conceptual design results evolved here should be useful input to the more detailed modeling activity for purposes of confirming or evaluating nuances in the different systems.

\subsection{Melter Geometrical Considerations}

Melter system options are based on the following considerations:

- Steady state operation

- $\quad$ ac or dc operation

- Transferred plasma-torch or graphite-arc operation

- Effective mixing lengths/vortices in the slag layer

- With/without metal melting to the bottom of the melter

- With/without a cold cap of feed above the melted slag

- Long arc versus short arc (with torch or graphite electrode).

Specific melter/electrode configurations include the following

- dc with one axial and one bottom anode

- dc transferred plasma torch with a long arc and bottom electrode

- dc with two parallel graphite electrodes

- Three-phase ac with three graphite electrodes

- dc with two concentric graphite electrodes.

The discussion includes the significant material properties, mixing and stirring effects in the slag, effect of the metal melt on the bottom, effect of radiation from a long arc, estimated effective melter geometries, and a summary of advantages and disadvantages of these and other factors. The actual dimensions and some characteristics based on $1 \mathrm{MT} / \mathrm{h}(1,000 \mathrm{~kg} / \mathrm{h})$ capacity melters are also given. 
This design effort is approximate, and should be verified by more detailed design or experiments. Nevertheless, the results give a first approximation of the differences in geometry and characteristics of the melters being considered and which could be used as input into the Buried Waste Integrated Demonstration melter modeling project to obtain more precise data.

\subsubsection{Melted Material Properties}

In order to put the arc melter configuration into perspective, one must understand the relative importance of the different materials to be melted and their widely different property values.

An appropriate viscosity range is important in order to obtain convective mixing and to pour the molten slag or metal. Viscosity decreases (becomes more fluid) with increasing temperature. Figure 6-1 shows a spectrum of viscosities with common liquids to indicate the fluidity involved. The waste slags are much more viscous than most of the other liquids shown and require higher temperatures.

The electrical conductivity is also significant in order to obtain the proper current flow and Joule heating in the slag, as well as to inhibit short circuiting the melt with the molten metal. Figure 6-2 shows a spectrum of electrical conductivities with common conductors to indicate the relative conductance involved. The waste slags are much less conductive than most of the other conductors shown and require high temperatures. Even at high temperatures, the waste slags are poor conductors (by several orders of magnitude) compared to metals or even graphite. The metal layer is a perfect conductor compared to the slag layer. This is one of the reasons noble metals are a problem in Joule-heated melters.

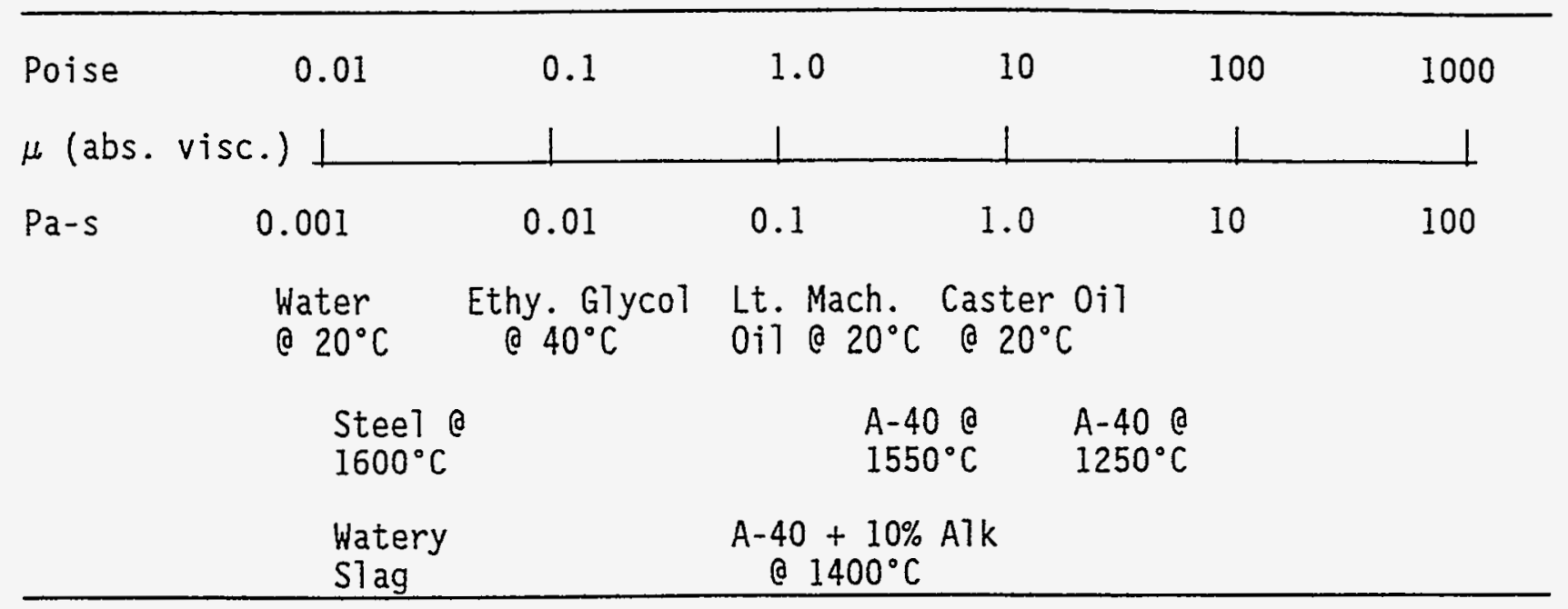

Figure 6-1. Viscosities of common fluids and some selected waste slag compositions. 


\begin{tabular}{|c|c|c|c|c|c|c|c|c|c|c|}
\hline$\rho(\mu \circ h m-c m)$ & 1.0 & 10 & 100 & 1000 & $10^{4}$ & $10^{5}$ & $10^{6}$ & $10^{7}$ & $10^{8}$ & $10^{9}$ \\
\hline$\sigma(\mathrm{mho} / \mathrm{m})$ & $10^{8}$ & $10^{7}$ & $10^{6}$ & $10^{5}$ & $10^{4}$ & 1000 & 100 & 10 & 1.0 & 0.1 \\
\hline & $\begin{array}{l}\mathrm{Cu}, \mathrm{Al} \\
\mathrm{C} 20^{\circ} \mathrm{C}\end{array}$ & $\begin{array}{l}\mathrm{Fe} \\
20^{\circ} \mathrm{C}\end{array}$ & \multicolumn{2}{|c|}{$\begin{array}{l}\text { Nichrome, } \\
\mathrm{Hg} \mathrm{C} 20^{\circ} \mathrm{C}\end{array}$} & \multicolumn{2}{|c|}{$\begin{array}{c}\text { Graphite } \\
\text { a } 20^{\circ} \mathrm{C}\end{array}$} & & $\begin{array}{l}\mathrm{A}-40 \\
1550^{\circ} \mathrm{C}\end{array}$ & $\begin{array}{l}\mathrm{A}-40^{\circ} \mathrm{O} \\
1250^{\circ} \mathrm{C}\end{array}$ & $\begin{array}{l}\mathrm{A}-60 \\
1200^{\circ} \mathrm{C}\end{array}$ \\
\hline
\end{tabular}

Figure 6-2. Electrical resistivities ( $p$ ) and conductivities ( $\sigma$ ) of common conductors and some selected waste slag compositions.

\subsubsection{Mixing and Stirring Effects in the Slag}

In this section, the melt is assumed to be all slag, no metal bottom melt. Configurations considered for the melters are shown in Figure 6-3. The dimension $b$ represents a selected dimension, the melter radius, to which the other melter dimensions are related. It is assumed that circular eddies or vortices are desired for good mixing and that their aspect ratio should not increase from circular by more than a factor of two or decrease by more than one-half of the diameter. Whether the eddy is driven by buoyancy or Lorentz (electromagnetic) forces is not an issue here.

A sketch of the first melter configuration, with an axial dc cathode and bottom anode, is shown in Figure 6-3a. Setting $b$ equal to the radius of the melter and assuming a short arc (or submerged electrodes), a circular eddy is obtained when the slag height is also b. In plan view, Figure 6-3a, similar distances are involved, with the velocities lower near the wall. Going to slag heights of $b / 2$, decreases the size of the eddy, possibly generating two horizontal eddies across the radius or changing the aspect ratio, or alternating between the two conditions. If two eddies are generated, the transport of energy and mass between material in each is decreased, thus decreasing heating and increasing melting time and/or required temperature. If the slag height is $2 \mathrm{~b}$, the aspect ratio of the eddy is increased vertically or smaller eddies are formed. Sufficient current could stabilize the flow and inhibit the generation of a second eddy at the lower level, though some splashing and additional volatilization may occur. As a result, it would appear that the best operation is with a slag height of from one to two radii, $b$.

The second melter configuration is for a dc transferred plasma torch with a long arc, as shown in Figure 6-3b. The long arc above the melt increases the heating rate of the melt surface, as well as to the melter walls and gas phase. Again, setting $b$ equal to the radius of the melter and assuming an axially centered torch, a circular eddy is obtained when the slag height is also b. For the same current, the arc attachment footprint at the melt surface would be larger. In the plan view, analogous to Figure 6-3a, similar distances are involved, with the velocities lower near the wall. Going to slag heights of $b / 2$ or $2 b$ should give similar results as the $d c$ short arc with the axial cathode above, but with lower vortex velocities. Again, it would appear that the best 

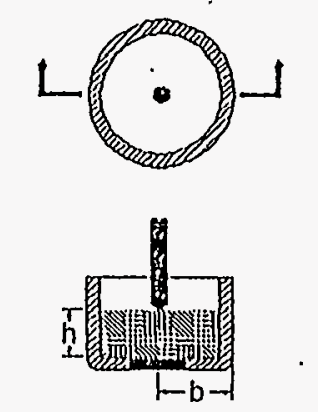

(a) DC axial electrode

9
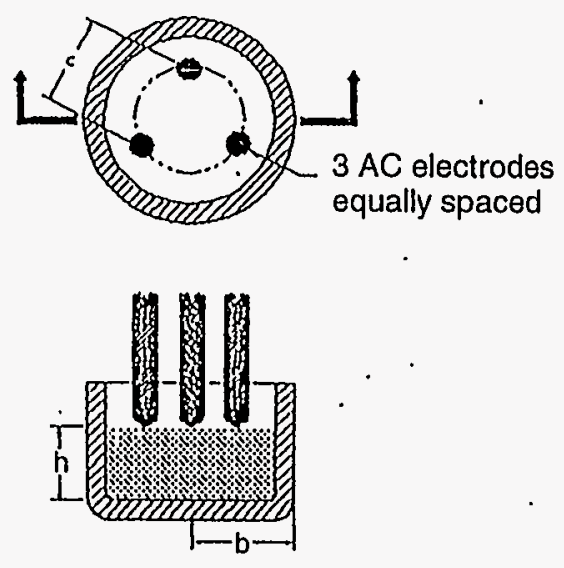

(d) 3-phase AC arc
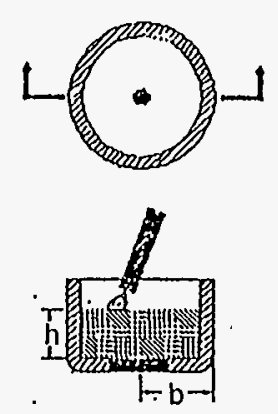

(b) DC transferred plasma torch
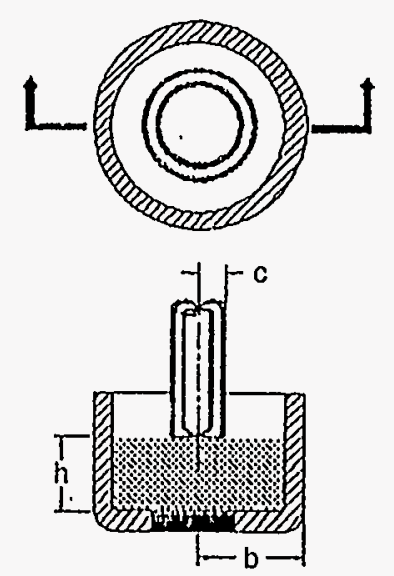

(e) DC concentric electrodes
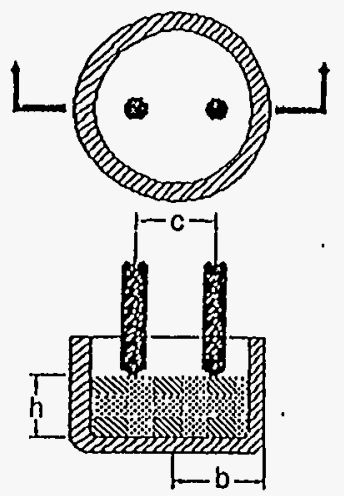

(c) DC parallel short arc
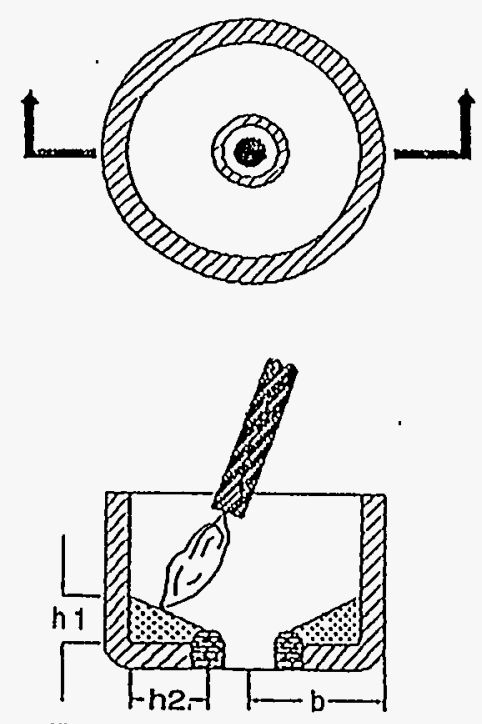

(f) Plasma centrifugal reactor

Figure 6-3. Melter configurations considered: (1) dc with axial cathode and bottom anode, (b) dc transferred plasma torch with long arc, (c) dc with two parallel graphite electrodes, (d) 3-phase ac with three graphite electrodes, (e) dc with concentric graphite electrodes, (f) dc torch with rotating chamber. 
operation is with a slag height of from one to two melter radii, b. The long arc could be employed with the Figure 6-3a, $c$ and $f$ dc melter configurations, with similar effects as discussed here.

The third melter configuration is for a dc transferred short arc with two parallel graphite electrodes, as shown in Figure 6-3c. The electric current goes from one electrode, through the melt, and into the other electrode. Setting $b$ equal to the radius of the melter and assuming short arcs, circular eddies should be obtained when the distance between the anode and cathode is $b / 2$ and the slag height is also $b / 2$. In the plan view, similar distances are involved, with the velocities lower near the wall. In addition, two more remote regions, near each wall on a plane between the electrodes, would probably generate weaker, low-flow eddies. Going to halved slag heights of $\mathrm{b} / 4$, decreases the size of the eddies, possibly generating two eddies laterally or changing the aspect ratio, or alternating between the two limits. If two eddies are generated across the radius, heat and mass transfer is decreased, as above. Since the optimum height is $b / 2$ (instead of $b$ ), it would appear that the best operation is with a slag height of from one-half to one radius, $b$.

The fourth melter configuration is for a 3-phase ac transferred arc with three graphite electrodes, as shown in Figure 6-3d. The current flow is similar to the dc parallel short arc, but alternates between a positive maximum, zero, and a negative minimum. This results in a smaller heating volume between two electrodes, but over a triangular region in the melt. Let $b$ again equal the radius of the melter, but set $c$ equal to the distance between any two electrodes (see the plan view) and assume a relatively short arc. A long arc here could be conducive to short circuits between the electrodes, but would provide some radiant heat to the slag or cold cap. Assume the current path between any two electrodes resembles a semicircle; then, the effective heating/eddy diameter would be equal to half the distance between electrodes, $c / 2$, and the effective slag height would be $c / 2$. The distance from any electrode to the wall should then be $c / 2$ for circular eddies. Using the relationships for a 30-degree triangle, the chamber radius is found to $b e b=c / 2+(c / 2) / \operatorname{Cos} 30=1.08 \mathrm{c}$. The eddy size outside of the electrode heating region is of diameter $\mathrm{c} / 2$, corresponding to the slag height. Halving the slag height to $\mathrm{c} / 4(\mathrm{~b} / 4.32)$, again doubles or broadens the eddy size, with the resultant lower velocity in the outer vortices.

Doubling the slag height to $\mathrm{c}(\mathrm{b} / 1.08)$ increases the distance between electrode current and melter bottom, decreasing mixing and increasing heating time or requiring higher temperatures. It appears that the optimum slag height would be near the heating dimension $c / 2$, e.g., from 75 to $125 \%$ of $c / 2$.

The fifth melter configuration is for a dc transferred arc with concentric graphite electrodes, as shown in Figure 6-3e. This configuration is usually used for starting the arc in a nontransferred mode between the electrodes and then shifting to a transferred arc mode after a conduction path to the bottom electrode is established. Operation is similar to the 3-phase ac arc system and also results in a smaller heating volume in the melt. Let $b$ again equal the radius of the melter, but set $c$ equal to the distance between the axis and the center of the outer electrode, and assume a relatively short arc. Attempting to run a long arc here would simply raise the arc above the melt with heating predominantly by radiation. Assume the current path between the two electrodes resembles a semicircle, then the effective heating/eddy radius would be equal to half the distance between electrodes, $c / 2$, and the effective slag height would be $c / 2$. The distance from the outer electrode to the wall should then be $c / 2$ for circular eddies. The melter radius is then $b=c+c / 2$ $=1.5 \mathrm{c}$. Halving the slag height from $\mathrm{c} / 2$ to $\mathrm{c} / 4(=\mathrm{b} / 6)$ again doubles or broadens the eddy size, 
with the resultant lower heat/mass transfer in the outer vortices. Doubling the slag height to $\mathrm{c}=$ $0.67 \mathrm{~b}$ increases the distance between electrode current and melter bottom, decreasing mixing and increasing heating time or required temperature. The stabilizing force available from the dc arc is not as strong as from the other dc melter configurations and rotates; hence, the thermal driving potential is lower. It appears that the optimum slag height would be near that for the other dc arc melters, e.g., from $c / 2(0.33 b)$ to $c(0.67 b)$.

The sixth melter configuration is for a dc transferred plasma torch with long arc and a rotating reactor, as shown in Figure 6-3f. The operation is similar the melter in Figure 6-3b, but the melt is forced up against the side wall by the centrifugal force. An angle of repose is formed as a resultant of the gravitational and centrifugal force. Again, setting $b$ equal to the radius of the melter and assuming a $\theta=45$ degree angle of repose, the equation between $b$ and the revolutions per second is $b=g /\left(4 \pi[\mathrm{rps}]^{2}\right)$. The average slag height is $h / 2=(b / 2) \tan \theta$, and the minimum slag height might be $\mathrm{h} / 4$ (though in practice this is a batch process and goes from near zero to the maximum). A medium or long arc is usually employed to keep the torch out of the way of the moving waste and melt.

The resulting dimensions for the slag layer only (no molten metal layer) are presented in Table 6-1, with the slag volume and recommended slag height and volume ranges. Of most interest is the slag volume $V_{s}$, which for a melter radius $b$ indicates the capacity of the melter in volume. The greatest capacity (smallest footprint/unit volume) is obtained with the dc axial electrode and torch. The dc parallel electrodes, ac 3-phase, and dc concentric are next with approximately half the capacity, and the dc rotating system has again $1 / 3$ the capacity, or $1 / 6$ the capacity of the dc axial electrode or torch systems.

\subsubsection{Geometrical Example}

Consider a melter capacity of $1 \mathrm{MT} / \mathrm{h}=1000 \mathrm{~kg} / \mathrm{h}$ throughput. Assume a 20 vol\% turnover ratio of feed to melter capacity, thus the melter would have a 5 MT capacity. Using IEB, the specific gravity is approximately 3.0 ; hence, the volume required is $5,000 \mathrm{~kg} / 3000 \mathrm{~kg} / \mathrm{m}^{3}=1.67 \mathrm{~m}^{3}$. An ideal power requirement for melting is $1.0 \mathrm{kWh} / \mathrm{kg}$ of material heated or approximately $1 \mathrm{MW}$ for a melter feedrate of $1,000 \mathrm{~kg} / \mathrm{hr}$. An additional $1-\mathrm{MW}$ would provide surplus capacity and to cover general wall heat losses.

Table 6-2 gives the dimensions required for the $1000 \mathrm{~kg} / \mathrm{h}$ throughput with a 5,000-kg melter capacity. The power requirements in Table 6-2 are based on measured slag V-I characteristics and a current of $1000 \mathrm{~A}$ (Eddy and Raivo 1995). The approximate heating duration is based on the $1-\mathrm{kWh} / \mathrm{kg}$ usually required divided by the Joule heating power required by the configuration.

\subsubsection{Effect of Radiation: Long Arc Versus Short Arc}

The long arc extending above the slag or cold cap provides radiant heat transfer to the slag or cold cap to assist the melting. The disadvantages are usually increased $\mathrm{NO}_{\mathrm{x}}$ production, increased volatilization of species, and increased radiant heat transfer losses to the melter side walls and roof. 
Table 6-1. A summary of approximate melter geometrical relationships.

\begin{tabular}{|c|c|c|c|c|c|c|}
\hline $\begin{array}{l}\text { Melter power, } \\
\text { electrodes }\end{array}$ & $\begin{array}{l}\text { Melter } \\
\text { radius }\end{array}$ & $\begin{array}{c}\text { Slag } \\
\text { height }\end{array}$ & $\begin{array}{c}\text { Slag } \\
\text { height } \\
\text { range }\end{array}$ & $\begin{array}{c}\text { Electrode } \\
\text { separation }^{\mathrm{a}} \\
\mathrm{c} \\
\end{array}$ & $\begin{array}{c}\text { Slag volume } \\
\mathrm{V}_{\mathrm{s}} \\
\end{array}$ & $\begin{array}{c}\text { Slag current } \\
\text { length } \\
\mathrm{L}_{\mathrm{s}} \\
\end{array}$ \\
\hline \multicolumn{7}{|l|}{ Slag layer only } \\
\hline dc, axial & b & b & $1-2 b$ & b & $\pi b^{3}$ & b \\
\hline $\mathrm{dc}$, torch & b & b & $1-2 b$ & $\mathrm{~b}+\mathrm{L}_{\mathrm{a}}$ & $\pi b^{3}$ & b \\
\hline $\mathrm{dc}$, parallel & b & $0.5 \mathrm{~b}$ & $0.5-1.0 \mathrm{~b}$ & b & $0.5 \pi b^{3}$ & b \\
\hline ac, three-phase & b & $0.46 \mathrm{~b}$ & $0.35-0.58 b$ & $0.93 b$ & $0.46 \pi b^{3}$ & $0.93 b$ \\
\hline dc, concentric & b & $0.33 b$ & $0.33-0.67 \mathrm{~b}$ & $0.67 \mathrm{~b}$ & $0.33 \pi b^{3}$ & $0.67 \mathrm{~b}$ \\
\hline $\mathrm{dc}$, rotating $-45^{\circ}$ & b & $0.5 b^{b}$ & $0.25-0.5 b$ & $0.94 b^{c}$ & $0.50 \mathrm{~b}^{3}$ & $0.94 \mathrm{~b}$ \\
\hline
\end{tabular}

Table 6-2. Dimensions of melters for the configurations considered.

Feed rate

Melter capacity

Melt volume

IEB specific gravity

Melt heating rate

Melter current
$1,000 \mathrm{~kg} / \mathrm{h}$

$5,000 \mathrm{~kg}$ (5/1 ratio)

$1.67 \mathrm{~m}^{3}$

3

$1 \mathrm{kWh} / \mathrm{kg}$

$1,000 \mathrm{~A}$

\begin{tabular}{lcccccc}
\hline $\begin{array}{c}\text { Melter power, } \\
\text { electrodes }\end{array}$ & $\begin{array}{c}\text { Melter } \\
\text { radius }\end{array}$ & $\begin{array}{c}\text { Slag } \\
\text { volume }\end{array}$ & $\begin{array}{c}\text { Melter } \\
\text { radius } \\
(\mathrm{m})\end{array}$ & $\begin{array}{c}\text { Slag } \\
\text { current } \\
\text { length } \\
(\mathrm{m})\end{array}$ & $\begin{array}{c}\text { Joule } \\
\text { heating } \\
\text { power } \\
(\mathrm{kW})\end{array}$ & $\begin{array}{c}\text { Approx. } \\
\text { heating } \\
\text { duration } \\
(\mathrm{h})\end{array}$ \\
\hline Slag layer only & & & & & & \\
dc, axial & $\mathrm{b}$ & $\pi \mathrm{b}^{3}$ & 0.81 & 0.81 & 1458 & 0.69 \\
dc, torch & $\mathrm{b}$ & $\pi \mathrm{b}^{3}$ & 0.81 & 0.81 & 1458 & 0.69 \\
dc, parallel & $\mathrm{b}$ & $0.5 \mathrm{~b}^{3}$ & 1.02 & 1.02 & 1836 & 0.54 \\
ac, 3-phase & $\mathrm{b}$ & $0.46 \mathrm{~b}^{3}$ & 1.16 & 1.08 & 1935 & 0.52 \\
dc, concentric & $\mathrm{b}$ & $0.33 \mathrm{~b}^{3}$ & 1.17 & 0.79 & 1413 & 0.71 \\
dc, rotating-45 & $\mathrm{b}$ & $0.50 \mathrm{~b}^{3}$ & 1.49 & 1.41 & 2538 & 0.39 \\
\hline
\end{tabular}


For a melter of radius $b$, the amount of effective radiant heat transfer will be proportional to the radiant shape factor from the plasma arc to the slag surface. The appropriate shape factor can be approximated by that between a vertical cylinder mounted at the center of a horizontal circular area (see Figure 6-4). The shape factor between the arc surface area $A_{1}$ and the horizontal circle $A_{2}$ (see Eckert 1973).

$$
F_{A_{1}-A_{2}}=\frac{1}{A_{1}} \int_{A_{1}} \int_{A_{2}} \frac{\operatorname{Cos} \beta_{1} \operatorname{Cos} \beta_{2}}{\pi^{2}} d A_{2} d A_{1}=\frac{1}{2} \tan ^{-1} \frac{b}{l}
$$

where $b$ is the melter slag radius, and $L_{a}$ is the plasma arc length or height, as shown in Figure 6-4. (The integration was performed manually as no appropriate shape factor table was available.) The arc diameter cancels out in the derivation.

Shape factors or view factor values range between zero and one. The variation of the shape factor between plasma arc and slag $\left(F_{a \cdot s}\right)$ as a function of the ratio of arc length to melter radius is plotted in Figure 6-5. The value decreases from about 0.8 at small $L_{a} / b$ to about 0.2 when $L_{a}$ is twice the radius $b$. The relative importance of the values is obtained by taking the ratio of the shape factors arc-to-slag $\left(F_{a-s}\right)$ and arc-to-walls $\left(F_{a-w}\right)$, where $F_{a-w}=1-F_{a-s .}$ The $F_{a-s} / F_{a-w}$ ratio, also plotted in Figure 6-5, decreases rapidly as the $L_{a} / b$ ratio increases. At $L_{a} / b=0.62$, equal shape factors and, hence, approximately equal radiative heat transfer occurs to the walls as to the slag. At $L_{a} / b=0.2$, a little more than twice the arc radiation is directed at the slag. In conclusion, the arc length should probably be less than $20 \%$ of the radius or $10 \%$ of the diameter in order to get more than $70 \%$ of the arc radiation directed at the slag. In actual practice, some of the radiation to refractory walls is reradiated to the slag, with the $+/-$ net value depending on the slag surface temperature.

A simple comparison of plasma arc heating to Joule heating can be made. The voltage drop in a high current (I) plasma arc is approximately $10 \mathrm{~V} / \mathrm{cm}$. For a plasma arc length $\mathrm{L}_{\mathrm{a}}$, the power dissipation is $\mathrm{W}_{\mathrm{a}}=(10 \mathrm{~V} / \mathrm{cm})^{*} \mathrm{~L}_{\mathrm{a}}{ }^{*} \mathrm{I}$. Approximately $10 \%$ of the energy is transmitted by radiation and the rest by convection to the electrodes or surrounding gas. Of that radiated, only the fraction $F_{a-s}$ reaches the slag. Therefore, the plasma energy radiated to the slag is $\mathrm{W}_{\mathrm{a}-\mathrm{s}}=1 * \mathrm{~F}_{\mathrm{a}}$ ${ }_{s}{ }^{*} \mathrm{~L}_{\mathrm{a}}{ }^{*} \mathrm{I}$. In the slag, the Joule heating component at the same current depends on the voltage drop, which is approximately double the arc value, or about $20 \mathrm{~V} / \mathrm{cm}$. The path length will depend on the melter configuration and be a function of melter diameter $b$. Heat losses to the refractory or water-cooled walls will need to pass through the slag either from radiation or Joule heating and, therefore, will not be deducted from either here. The net Joule heating power to the slag is $W_{J}=20^{*} I^{*} L_{s}{ }^{*} b$, where $L_{s}=c_{b}{ }^{*} b$ is the current path length in the slag, and $c_{b}$ is the melter-dependent coefficient of $b$ to obtain the current path in the slag. The ratio of plasma arc to Joule heated power is then

$$
\frac{W(\text { long arc })}{W(\text { Joule heat })}=\frac{1\left(F_{a-s} L_{a} I\right)}{20 c b I}=\frac{F_{a-s}\left(L_{d} / b\right)}{20 c}
$$




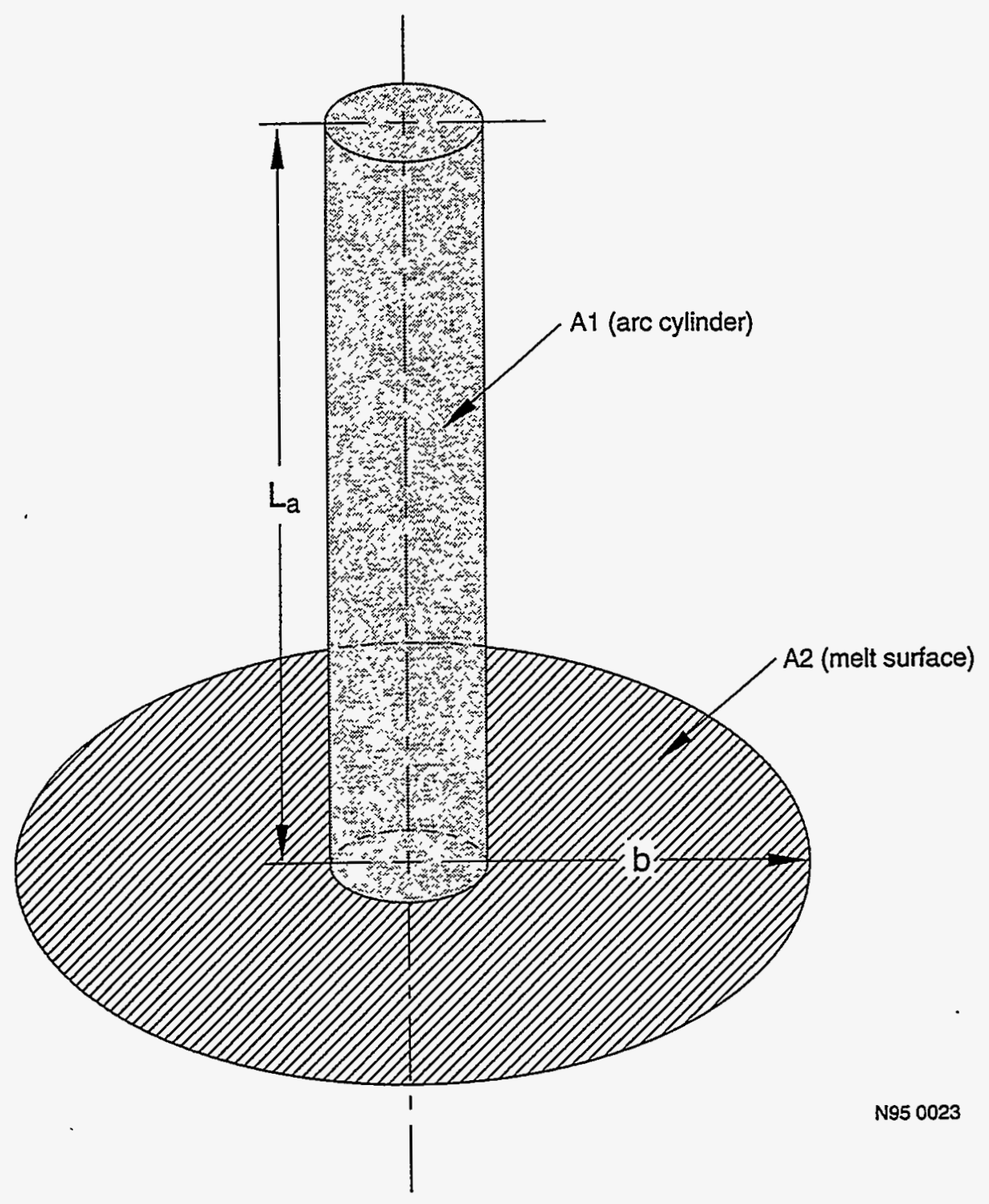

Figure 6-4. The cylindrical-arc-to-circular-slag surface geometry for shape factor calculation.

As $\mathrm{L}_{\mathrm{a}} / \mathrm{b}$ increases, $\mathrm{F}_{\mathrm{a}-\mathrm{s}}$ decreases, with the maximum numerator product value of about 0.65 and a value of 0.15 at $L_{a} / b=20 \%$. The values of $c_{b}$ are near unity for the melters considered, except for the concentric electrode geometry with $c_{b}=b / 3$. The maximum ratio of arc/Joule heating is then about $3 \%$, and operationally would be less than $1 \%$. This puts plasma arc heating no greater than $3 \%$ of the total power and for practical purposes less than $1 \%$ of total power. The convection due to entrainment of surrounding gas is another factor that may contribute significantly to the slag heating, but the calculation is beyond the scope of this work.

Most long arc advocates believe the long arc is a more significant heater than that indicated here, but they are comparing with (a) metal melts where electrical conductivities are orders of magnitude larger and field strengths $(\mathrm{V} / \mathrm{cm}$ ) smaller than one gets in slag, or (b) scrap melting where the arc is submerged and radiates and convects heat to the surrounding scrap. 


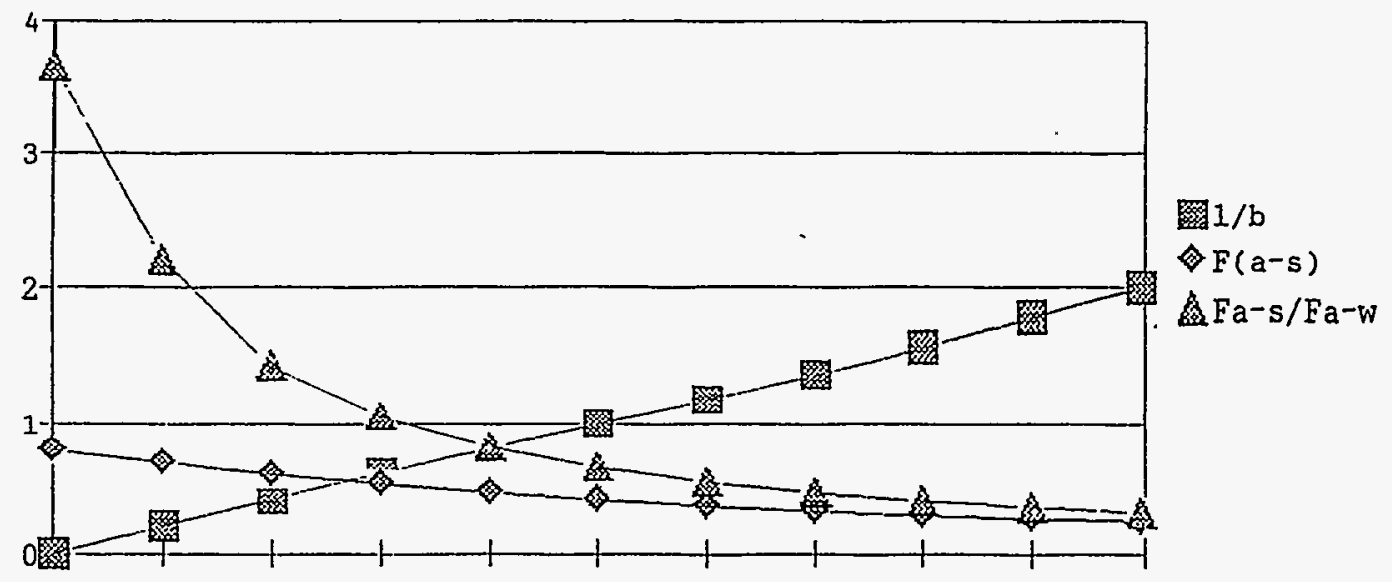

Figure 6-5. The variation of the shape factor between plasma arc and slag $\left(\mathrm{F}_{\mathrm{a-s}}\right)$ as a function of the ratio of arc length to melter radius $(L / b)$.

The long arc should have an additional vaporization of HVPM, fuming of nonvolatiles, and potential loss of TRU, which would need to be balanced against additional stability and radiative heating. A more detailed study involving additional literature search, melter modeling and/or experimental energy balances may show increases in the plasma heating contribution, but they are not expected to be significant.

Adding a long arc will either increase the input power requirements or lengthen the heating duration for a fixed power supply size. Table 6-3 shows the power required as a function of current for different long arc lengths. As discussed above, the power required by the plasma arc

Table 6-3. Plasma arc and slag power input as a function of current and arc length for a 1-m slag current length.

\begin{tabular}{|c|c|c|c|c|c|c|c|c|c|}
\hline \multirow{3}{*}{$\frac{I(A)}{1000}$} & & & \multirow{3}{*}{$\frac{E_{p}(V / c m)}{8.3}$} & \multirow{3}{*}{$\frac{V(V)}{253}$} & \multirow{3}{*}{$\frac{\mathrm{W}_{\mathrm{p}}(\mathrm{kW})}{253}$} & \multirow{3}{*}{$\frac{E_{s}(V / c m)}{18}$} & \multicolumn{2}{|c|}{ For $\mathrm{L}_{\mathrm{s}}=1 \mathrm{~m}$} & \multirow{3}{*}{$\frac{\mathrm{W}_{\text {tot }}(\mathrm{kW})}{2053}$} \\
\hline & \multicolumn{2}{|c|}{$\mathrm{L}_{\mathrm{p}}(\mathrm{ft}, \mathrm{cm})$} & & & & & $\mathrm{V}_{\mathrm{s}}(\mathrm{V})$ & $\mathrm{w}_{\mathrm{s}}(\mathrm{kW})$ & \\
\hline & 1.0 & 30.5 & & & & & 1800 & 1800 & \\
\hline 1000 & 2.0 & 61.0 & 8.3 & 506 & 506 & $n$ & $n$ & $n$ & 2306 \\
\hline 1000 & 3.0 & 91.5 & 8.3 & 759 & 759 & $n$ & $"$ & $n$ & 2559 \\
\hline 2000 & 1.0 & 30.5 & 13.3 & 406 & 811 & 23 & 2300 & 4600 & 5411 \\
\hline 2000 & 2.0 & 61.0 & 13.3 & 811 & 1623 & $n$ & " & $n$ & 6223 \\
\hline 2000 & 3.0 & 91.5 & 13.3 & 1217 & 2434 & " & " & $n$ & 7034 \\
\hline 3000 & 1.0 & 30.5 & 18.3 & 558 & 1674 & 28 & 2800 & 8400 & 10074 \\
\hline 3000 & 2.0 & 61.0 & 18.3 & 1116 & 3348 & $"$ & $"$ & $"$ & 11748 \\
\hline 3000 & 3.0 & 91.5 & 18.3 & 1674 & 5022 & $n$ & $"$ & $n$ & 13422 \\
\hline
\end{tabular}


is large compared to the heating benefit if the arc is not submerged into the medium to be melted and when the slag has a much lower conductivity than metal. As a result, long arcs will greatly increase power and voltage demands without a corresponding increase in heating of the waste material. Most systems can be operated with variable arc lengths, if so designed.

\subsection{Summary of Advantages and Disadvantages}

A list of advantages and disadvantages of various melter design options is presented in Table 6-4. A discussion and summary regarding different melter options on an individual basis follows, after which configurations are considered in systems employing those options.

\subsubsection{Melter Options Considered Individually}

Each melter option is summarized in Table 6-5. The separate incinerator and melter option has some advantages in operation and control of TRU/LLW over the combined incinerator/melter option, but adds additional equipment, material handling, building footprint, and cost. Since there is no clear advantage, either system could be used, depending on how it compliments other melter options.

The rotating chamber has some advantages that may make it advantageous in certain systems, in spite of the additional maintenance concerns. In general, the fixed chamber is preferred, but the choice may be affected by the system in which it is employed.

The dc melter power has advantages in lower graphite consumption, sealing and control, but is a little more expensive. DC power is preferred, but ac power is a close second.

The plasma torch is more suited to oxidizing atmospheres, but coated graphite electrodes are also used industrially. The high maintenance cost of plasma torches has led them to be replaced in similar applications with electric arc furnace dust processing, but in neutral or reducing atmospheres. Other industrial applications add three propane burners around the melter circumference to oxidize organics or to more evenly heat the top of the melt. A bench or pilotscale test should be performed to test various existing coatings for resistance to oxidation of the graphite electrodes. If a neutral or reducing environment is selected, the graphite electrodes are preferred. If an oxidizing environment is selected, additional information on relative maintenance of the two methods should be obtained. It is fairly easy to switch from torch to graphite or vice versa.

The short arc length can result in less radionuclide and HVPM entrainment, produces less $\mathrm{NO}_{x}$ and is more energy efficient, but may be less stable. The long arc may be required in systems with plasma torches. The short arc is preferred, but the choice may be system dependent.

The electrode configuration with all electrodes above the melt minimizes melter bottom maintenance problems but increases sealing problems on the top. Some evidence exists that bottom electrodes could last throughout the campaign, but it is singular. The fewer electrodes in the top of the melter, the better. Each potential configuration has advantages and drawbacks, apparently none dominating. At this point, the choice is too even to call and may be system dependent. 
Table 6-4. Relative advantages of various melter options.

\begin{tabular}{|c|c|c|}
\hline Melter option & $\begin{array}{l}\text { Advantages of the first } \\
\text { (versus the second) }\end{array}$ & $\begin{array}{l}\text { Disadvantages of the first } \\
\text { (versus the second) }\end{array}$ \\
\hline $\begin{array}{l}\text { Thermal desorption/ } \\
\text { pyrolysis/oxidation } \\
\text { (1) prior to melter } \\
\text { (2) in melter }\end{array}$ & $\begin{array}{l}\text { Major } \\
\text {-Minimizes entrainment of TRU/LL } \\
\text {-Simplifies control system for unit } \\
\text { Minor } \\
\text {-Minimizes volatilization of HVPM } \\
\text {-Minimizes reducing state in melt } \\
\text {-Smaller units easier to decommission } \\
\text {-Smaller capacity melter } \\
\text {-Can incinerate or melt while other is in } \\
\text { maintenance } \\
\text {-more throughput for given melter size }\end{array}$ & $\begin{array}{l}\text { Major } \\
\text {-Requires additional unit } \\
\text {-Requires more gas flow } \\
\text {-May require 2nd offgas system } \\
\text {-Requires additional material handling } \\
\text {-Larger secondary confinement } \\
\text { Minor } \\
\text {-Requires additional heat source } \\
\text {-Requires additional control system } \\
\text {-Lower thermal efficiency } \\
\text {-More inventory space required }\end{array}$ \\
\hline $\begin{array}{l}\text { Melter chamber } \\
\text { (1) rotating } \\
\text { (2) fixed chamber }\end{array}$ & $\begin{array}{l}\text { Major } \\
\text {-Feeding behind arc minimizes volatilization } \\
\text { and improves melting } \\
\text {-Decreases residence time } \\
\text { Minor } \\
\text {-Improves mixing, homogeneity } \\
\text {-Heats more uniformly to melt scale } \\
\text {-Easy to start/stop tapping } \\
\text {-Less problems with plugging } \\
\text {-Pressure pulses accommodated through } \\
\text { tap hole and secondary chamber }\end{array}$ & $\begin{array}{l}\text { Maior } \\
\text {-Moving parts increase maintenance } \\
\text {-Larger volume unit required } \\
\text {-More difficult to separate slag and metal } \\
\text { (one tap) } \\
\text {-More entrainment - no cold cap } \\
\text { Minor } \\
\text {-Additional capital cost } \\
\text {-Can short circuit gas flows }\end{array}$ \\
\hline $\begin{array}{l}\text { Melter power } \\
\text { (1) dc power } \\
\text { (2) ac power }\end{array}$ & $\begin{array}{l}\text { Major } \\
\text {-Less graphite consumption } \\
\text {-Easier to control } \\
\text {-Usually fewer electrodes and sealing } \\
\text { problems } \\
\text { Minor } \\
\text {-Improves stirring } \\
\text {-More uniform heating throughout }\end{array}$ & $\begin{array}{l}\frac{\text { Major }}{- \text { None }} \\
\text { Minor } \\
\text {-More equipment required in system } \\
\text {-More expensive system }\end{array}$ \\
\hline $\begin{array}{l}\text { Electrode materials } \\
\text { (1) plasma torch } \\
\text { (2) graphite electrodes }\end{array}$ & $\begin{array}{l}\text { Maior } \\
\text {-Can run air/oxygen for oxidation } \\
\text {-Improves sealing of top } \\
\text { Minor } \\
\text {-Easier to gimbal for direction } \\
\text {-Will not break off into melt }\end{array}$ & $\begin{array}{l}\text { Major } \\
\text {-Much higher maintenance } \\
\text {-Requires more gas flow } \\
\text { - Water cooled torch will leak } \\
\text {-Requires running in long arc mode } \\
\text { Minor } \\
\text {-Lower current levels(though probably } \\
\text { adequate) }\end{array}$ \\
\hline $\begin{array}{l}\text { Arc length } \\
\text { (1) short arc } \\
\text { (2) long arc }\end{array}$ & $\begin{array}{l}\text { Major } \\
\text {-Less entrainment of TRU/LL } \\
\text {-Less radiation to walls \& top } \\
\text { Minor } \\
\text {-Less volatilization of HVPM } \\
\text {-Can run with a cold cap } \\
\text {-Mainly a Joule Heating mode without } \\
\text { touching melt } \\
\text {-Less } \mathrm{NO}_{\mathrm{x}} \text { generation }\end{array}$ & $\begin{array}{l}\frac{\text { Major }}{- \text { None }} \\
\text { Minor } \\
\text {-Operation may not be as stable }\end{array}$ \\
\hline
\end{tabular}


Table 6-4. (continued).

\begin{tabular}{|c|c|c|}
\hline Melter option & $\begin{array}{l}\text { Advantages of the first } \\
\text { (versus the second) }\end{array}$ & $\begin{array}{l}\text { Disadvantages of the first } \\
\text { (versus the second) }\end{array}$ \\
\hline $\begin{array}{l}\text { Electrode configuration } \\
\text { (1) all above melt } \\
\text { (2) one bottom electrode }\end{array}$ & $\begin{array}{l}\text { Major } \\
\text {-Reduced maintenance } \\
\text { Minor } \\
\text {-Reduction of risk } \\
\text {-Less likely for lead to leak through cracks } \\
\text { in bottom around electrodes }\end{array}$ & $\begin{array}{l}\frac{\text { Major }}{\text {-None }} \\
\text { Minor } \\
\text {-Worse mixing } \\
\text {-Worse uniform heating } \\
\text {-Worse residence time } \\
\text {-Worse gas sealing }\end{array}$ \\
\hline $\begin{array}{l}\text { Redox state } \\
\text { (1) oxidizing } \\
\text { (2) reducing }\end{array}$ & $\begin{array}{l}\text { Major } \\
\text {-Reduces entrainment of TRU/LL } \\
\text {-Oxidizes residual carbon/graphite } \\
\text { Minor } \\
\text {-Reduces volatilization of HVPM } \\
\text {-FWF stable crystal fraction increased } \\
\text {-Reduce formation of dioxins }\end{array}$ & $\begin{array}{l}\frac{\text { Major }}{\text {-None }} \\
\text { Minor } \\
\text {-Higher gas flow rates } \\
\text {-Requires additional equipment }\end{array}$ \\
\hline $\begin{array}{l}\text { Tap or pour method } \\
\text { (1) tapping } \\
\text { (2) pouring }\end{array}$ & $\begin{array}{l}\frac{\text { Maior }}{\text { System is fixed (excl. PCR) }} \\
\text {-Can easily separate slag \& metal tapping } \\
\text {-Better control of vapors } \\
\text { Minor } \\
\text {-Better control of canister location } \\
\text {-Perceived cleaner operation } \\
\text {-Routine operation for automation }\end{array}$ & $\begin{array}{l}\frac{\text { Major }}{\text {-None }} \\
\text { Minor } \\
\text {-More difficult to stop flow }\end{array}$ \\
\hline $\begin{array}{l}\text { Containment } \\
\text { (1) refractory/skull } \\
\text { (2) refractory only }\end{array}$ & $\begin{array}{l}\text { Major } \\
\text {-Minimize corrosion } \\
\text {-Cyclic skull melt to minimize diffusion of } \\
\text { TRU \& LL } \\
\frac{\text { Minor }}{- \text { None }}\end{array}$ & $\begin{array}{l}\frac{\text { Major }}{\text {-None }} \\
\text { Minor } \\
\text {-Requires additional cooling } \\
\text {-Requires additional power } \\
\text {-Requires additional monitoring \& control }\end{array}$ \\
\hline $\begin{array}{l}\text { Water cooling } \\
\text { (1) external gravity versus } \\
\text { (2) internal forced }\end{array}$ & $\begin{array}{l}\frac{\text { Maior }}{\text {-Minimize water leak eruptions }} \\
\text { Minor } \\
\text {-Lower cost }\end{array}$ & $\begin{array}{l}\frac{\text { Maior }}{- \text { None }} \\
\text { Minor } \\
\text {-May limit geometry } \\
\text {-Smaller range of cooling capacity }\end{array}$ \\
\hline $\begin{array}{l}\text { Cold cap } \\
\text { (1) With (thick or thin) } \\
\text { (2) Without }\end{array}$ & $\begin{array}{l}\frac{\text { Major }}{\text {-Reduces entrainment of TRU/LL }} \\
\text {-Reduces heat transfer to walls, top } \\
\text { Minor } \\
\text {-Reduces volatilization of HVPM } \\
\text {-Better slag homogeneity with thin } \\
\text {-Reduces plenum gas temperature }\end{array}$ & $\begin{array}{l}\text { Major } \\
\text {-May form dioxins with thick cold cap } \\
\frac{\text { Minor }}{\text {-None }}\end{array}$ \\
\hline
\end{tabular}


Table 6-5. Summary of preliminary decisions on melter options.

Prior or combined incineration

Rotating or fixed chamber

dc or ac power

Torch or graphite electrodes

Long or short arc

Electrode configuration

Redox state

Tap or pour

Containment

Cooling method

Cold cap
Closely balanced.

Choice may depend on other options.

Fixed preferred.

Choice may depend on system.

dc power preferred.

ac power is a close second.

Graphite electrodes preferred.

Need more data on oxidizing environments.

Short arc preferred.

Long/medium arc may be required with torches.

Viable options about even.

Choice may depend on system.

Require oxidizing state for combustibles.

Prefer oxidizing state for molten basalt.

Tapping preferred.

Refractory and skull wall preferred.

Gravity water cooling preferred.

Thin cold cap preferred.

The oxidizing redox state is required to oxidize the combustibles in the incinerator or melter and is beneficial in reducing entrainment and in generating the waste form. Reduction is not beneficial and not preferred.

The tapping of molten basalt and molten metal allows the separation of basalt and metal, easier collection of any vapors given off, and better control than the tilt and pour method; hence, tapping is preferred.

The refractory plus skull on the walls of the melter allows a skull to be used to control corrosion, melt off TRU and LL nuclide diffusion, and yields energy efficiency. Refractory only would require replacement periodically due to corrosion and buildup of radionuclides. Cold water-cooled walls are possible, but require much higher maintenance, and eruptions from water cooling leaks into the melter are possible. The skull and refractory are the preferred choice.

The gravity water cooling of the melter provides sufficient cooling for a skull for controlling corrosion and eliminates eruptions from water cooling leaks into the melter. It is the preferred choice. Other methods may be system dependent.

The thin cold cap reduces entrainment of radionuclide and HVPM, limits radiation to the walls and top. The thick cold cap could improve these effects further, with the exception of the 
possible formation of dioxins, scaling, and buildup of other undesirable effects in the cold cap. The order of preference is thin, thick, and no cold cap.

If a design decision is required, then the option features can be designated as the preferred option, as equivalent options, as second choice options, and as undesirable options. Preliminary single-option choices are listed in Table 6-6 on this basis. The options have been rearranged to put the easiest decisions first and the most difficult last.

\subsection{Evaluation of Melter Systems}

\subsubsection{Weighting Melter Options and Features}

Some options are more important than others, and some features are more or less desirable for an option than the others. The basis for quantifying the options and features is given in Table 6-7. The number scale used is a progressive scale, with 1.0 representing the highest (or critical) importance and 0.1 representing low importance, with zero indicating no importance.

Table 6-6. Summary of preliminary decisions on melter options in priority of easiest decisions first.

\begin{tabular}{|c|c|c|c|c|}
\hline Melter option & Preferred option & $\begin{array}{l}\text { Equivalent } \\
\text { option }\end{array}$ & $\begin{array}{l}\text { Second choice } \\
\text { option }\end{array}$ & Undesirable option \\
\hline $\begin{array}{l}\text { Melter } \\
\text { containment }\end{array}$ & $\begin{array}{l}\text { Skull wall plus } \\
\text { refractory }\end{array}$ & & Refractory & Cold metal wall \\
\hline Cooling method & $\begin{array}{l}\text { Gravity water } \\
\text { cooling }\end{array}$ & & $\begin{array}{l}\text { Internal water } \\
\text { cooling }\end{array}$ & Gas cooling \\
\hline Cold cap & Thin cold cap & & Thick cold cap & No cold cap \\
\hline $\begin{array}{l}\text { Tap or pour } \\
\text { method }\end{array}$ & $\begin{array}{l}\text { Tap basalt and } \\
\text { metal separately }\end{array}$ & & $\begin{array}{l}\text { Pour basalt/metal } \\
\text { mixture }\end{array}$ & \\
\hline Redox state & $\begin{array}{l}\text { Oxidizing organics } \\
\text { and basalt }\end{array}$ & & & $\begin{array}{l}\text { Reducing organics, } \\
\text { reducing basalt, } \\
\text { oxidizing metal }\end{array}$ \\
\hline Arc length & Short arc & & Medium arc & Long arc \\
\hline Electrodes & Graphite & & Plasma torch & \\
\hline Power & $\mathrm{dc}$ & ac & & \\
\hline Chamber & Fixed & & Rotating & \\
\hline Combustion & Prior to melter & Within melter & & \\
\hline $\begin{array}{l}\text { Electrode } \\
\text { configuration }\end{array}$ & $\begin{array}{l}\text { All electrodes } \\
\text { above melt }\end{array}$ & $\begin{array}{l}\text { Both top and } \\
\text { bottom } \\
\text { electrode(s) }\end{array}$ & & \\
\hline
\end{tabular}


Table 6-7. Option and feature weight rating scale.

\begin{tabular}{ccl}
\hline Value & Option importance & Feature rating \\
\hline 1.0 & Highest & Excellent \\
0.7 & High & Very good \\
0.4 & Medium & Good \\
0.2 & Lesser & Fair \\
0.1 & Low & Poor \\
0.0 & None & Bad \\
\hline
\end{tabular}

Table 6-8 presents the option weights obtained based on the relative importance of each option. The major operational effects on which the weights are based are given in Table 6-4. The option of "prior treatment" was ambiguous and has been eliminated from this consideration. Table 6-8 gives the option weights obtained from preliminary estimates, four arc melter experts, four plasma torch experts, and all eight experts. The standard deviations are also given.

The weightings of the various features of each option are given in Table 6-9. Additional variations of features are included in order to present a fuller spectrum for rating, to include features that might be used on other systems, and for possible consideration. The features are given ratings relative to each other, but are also based as excellent, very good, good, fair, poor, and bad levels for a semi-absolute scale. The scale recommended for the range of values is given in Table 6-7. The needs and advantages or disadvantages of Table 6-4 are used to determine the rating values in Table 6-9.

\subsubsection{Melter System Evaluation Results}

Table 6-10 considers melter systems that are being employed in demonstrations. The feature options being used are identified, and values are entered from the preliminary weights from Tables 6-8 and 6-9. Some systems are not complete or are bench scale (e.g., the INEL IRC melter), so expected options have been assumed. The total score for a melter system is the sum given in the bottom row. The last column contains the maximum values of option feature scores. Its sum of 4.02 represents the maximum system score available, but may not be an attainable score because some features may not be compatible on the same system. Systems requiring more maintenance and giving more entrainment or volatilization have obtained lower scores.

Table 6-10 gives the systems with their present (original) or assumed options. In Table 6-11, the melter systems have been improved by using higher ranking features where possible without changing the basic melter concept employed. Some systems are not very flexible and are difficult to modify to improve the sum score. The greatest improvement was accomplished in the MTT dc arc melter system, in part by shifting from a graphite containment to a skull/refractory 
Table 6-8. Weighting values for the melter options.

\begin{tabular}{|c|c|c|c|c|c|c|c|}
\hline \multirow[b]{2}{*}{ Option } & \multirow{2}{*}{$\begin{array}{l}\text { Preliminary } \\
\text { estimate }\end{array}$} & \multicolumn{2}{|c|}{$\begin{array}{c}\text { Four arc melter } \\
\text { experts }\end{array}$} & \multicolumn{2}{|c|}{$\begin{array}{l}\text { Four plasma torch } \\
\text { experts }\end{array}$} & \multicolumn{2}{|c|}{ All eight experts } \\
\hline & & mean & std. dev. & mean & std. dev. & mean & std. dev. \\
\hline $\begin{array}{l}\text { Melter } \\
\text { containment }\end{array}$ & 0.6 & 0.750 & 0.191 & 0.400 & 0.216 & 0.589 & 0.252 \\
\hline Cooling & 0.5 & 0.575 & 0.150 & 0.325 & 0.171 & 0.478 & 0.205 \\
\hline Cold cap & 0.7 & 0.625 & 0.150 & 0.375 & 0.236 & 0.489 & 0.215 \\
\hline Tap/pour & 0.2 & 0.325 & 0.150 & 0.325 & 0.250 & 0.333 & 0.180 \\
\hline Redox state & 0.5 & 0.500 & 0.163 & 0.525 & 0.236 & 0.511 & 0.176 \\
\hline Arc length & 0.5 & 0.575 & 0.150 & 0.475 & 0.050 & 0.522 & 0.109 \\
\hline Electrodes & 0.7 & 0.725 & 0.050 & 0.600 & 0.115 & 0.667 & 0.100 \\
\hline Power-ac/dc & 0.1 & 0.100 & 0.000 & 0.250 & 0.300 & 0.167 & 0.200 \\
\hline Chamber & 0.3 & 0.325 & 0.050 & 0.375 & 0.096 & 0.356 & 0.073 \\
\hline $\begin{array}{l}\text { Electrode } \\
\text { configuration }\end{array}$ & 0.3 & 0.350 & 0.058 & 0.350 & 0.252 & 0.367 & 0.166 \\
\hline
\end{tabular}

containment. Significant improvements were also obtained in plasma torch systems by switching to graphite electrodes. Missing from the evaluation method in Tables 6-10 and 6-11 are

corrections for coupling in which two or more options are combined and operated in such a way to improve (or lower) the effective score.

Table 6-10 is an example of the procedure used to obtain the values in Table 6-12 in order to obtain a comparison of the preliminary weights and the combined and the separate arc melter and plasma torch experts weightings. The maximum values in Table 6-12 have been normalized to one.

Comparing the results calculated from the arc melter experts versus the plasma torch experts for each of the melter systems, the values for the arc melter systems are almost the same, but the plasma torch systems are much different. There appears to be either a bias towards (by the plasma torch experts) or away from (by the arch melter experts) the plasma torch systems. The highest plasma torch system is the plasma hearth with refractory in the chamber.

The results based on preliminary weights agree very well with the A.M. expert weighted results, and, therefore, differ from the plasma torch expert results for plasma torch systems. 
Table 6-9. Weighting values for the melter-option features.

\begin{tabular}{|c|c|c|c|c|c|c|c|}
\hline \multirow[b]{2}{*}{ Option } & \multirow{2}{*}{$\begin{array}{l}\text { Preliminary } \\
\text { estimate }\end{array}$} & \multicolumn{2}{|c|}{$\begin{array}{c}\begin{array}{c}\text { Four arc melter } \\
\text { experts }\end{array} \\
\end{array}$} & \multicolumn{2}{|c|}{$\begin{array}{l}\text { Four plasma } \\
\text { torch experts }\end{array}$} & \multicolumn{2}{|c|}{ All eight experts } \\
\hline & & mean & std. dev. & mean & std. dev. & mean & std. dev. \\
\hline \multicolumn{8}{|l|}{ Melter containment } \\
\hline Skull/refr & 0.7 & 0.800 & 0.141 & 0.700 & 0.000 & 0.744 & 0.101 \\
\hline Refractory & 0.3 & 0.375 & 0.150 & 0.350 & 0.100 & 0.356 & 0.113 \\
\hline Graphite & 0.1 & 0.150 & 0.100 & 0.100 & 0.000 & 0.122 & 0.067 \\
\hline Skull/metal & 0.1 & 0.100 & 0.000 & 0.100 & 0.000 & 0.100 & 0.000 \\
\hline \multicolumn{8}{|l|}{ Cooling } \\
\hline Gravity water & 1.0 & 1.00 & 0.000 & 0.850 & 0.300 & 0.878 & 0.244 \\
\hline Forced water & 0.4 & 0.500 & 0.200 & 0.550 & 0.173 & 0.544 & 0.174 \\
\hline Forced air & 0.1 & 0.100 & 0.000 & 0.200 & 0.141 & 0.144 & 0.101 \\
\hline \multicolumn{8}{|l|}{ Cold cap } \\
\hline Thick & 0.5 & 0.500 & 0.000 & 0.350 & 0.173 & 0.433 & 0.132 \\
\hline Thin & 0.7 & 0.700 & 0.000 & 0.600 & 0.115 & 0.656 & 0.088 \\
\hline None & 0.2 & 0.200 & 0.000 & 0.475 & 0.320 & 0.322 & 0.244 \\
\hline \multicolumn{8}{|l|}{ Tap/pour } \\
\hline Tap & 1.0 & 1.000 & 0.000 & 0.725 & 0.377 & 0.878 & 0.273 \\
\hline Tap together & 0.2 & 0.200 & 0.000 & 0.475 & 0.377 & 0.322 & 0.273 \\
\hline Pour & 0.2 & 0.200 & 0.000 & 0.475 & 0.377 & 0.322 & 0.273 \\
\hline \multicolumn{8}{|l|}{ Redox state } \\
\hline Oxidizing & 1.0 & 1.000 & 0.000 & 1.000 & 0.000 & 1.000 & 0.000 \\
\hline Neutral & 0.5 & 0.500 & 0.000 & 0.500 & 0.000 & 0.500 & 0.000 \\
\hline Reducing & 0.1 & 0.425 & 0.427 & 0.100 & 0.000 & 0.244 & 0.313 \\
\hline \multicolumn{8}{|l|}{ Arc length } \\
\hline Submerged & - & 1.000 & 0.000 & 0.775 & 0.287 & 0.900 & 0.212 \\
\hline Short & 1.0 & 1.000 & 0.000 & 0.775 & 0.287 & 0.844 & 0.246 \\
\hline Medium & 0.5 & 0.500 & 0.000 & 0.475 & 0.050 & 0.456 & 0.101 \\
\hline Long & 0.0 & 0.000 & 0.000 & 0.125 & 0.150 & 0.056 & 0.113 \\
\hline \multicolumn{8}{|l|}{ Electrodes } \\
\hline Pl. torch & 0.3 & 0.300 & 0.000 & 0.375 & 0.096 & 0.333 & 0.071 \\
\hline Graphite & 0.7 & 0.700 & 0.000 & 0.625 & 0.000 & 0.667 & 0.071 \\
\hline \multicolumn{8}{|l|}{ Power-ac/dc } \\
\hline $\mathrm{dc}$ & 0.7 & 0.675 & 0.126 & 0.700 & 0.000 & 0.689 & 0.078 \\
\hline ac & 0.5 & 0.525 & 0.126 & 0.550 & 0.100 & 0.556 & 0.113 \\
\hline \multicolumn{8}{|l|}{ Chamber } \\
\hline Rotating & 0.3 & 0.300 & 0.000 & 0.375 & 0.250 & 0.333 & 0.158 \\
\hline Tiltable & 0.5 & 0.450 & 0.100 & 0.425 & 0.150 & 0.444 & 0.113 \\
\hline Fixed & 0.7 & 0.725 & 0.050 & 0.600 & 0.200 & 0.667 & 0.141 \\
\hline \multicolumn{8}{|l|}{ Electrode config. } \\
\hline 4-dc above & 0.3 & 0.275 & 0.050 & 0.275 & 0.126 & 0.256 & 0.101 \\
\hline 3-ac above & 0.4 & 0.400 & 0.000 & 0.400 & 0.000 & 0.400 & 0.000 \\
\hline 2-dc above & 0.5 & 0.475 & 0.050 & 0.450 & 0.058 & 0.422 & 0.130 \\
\hline 1 top/1 botm & 0.4 & 0.400 & 0.141 & 0.350 & 0.173 & 0.378 & 0.139 \\
\hline
\end{tabular}


Table 6-10. Qualitative ranking of melter systems with original options.

\begin{tabular}{lll}
\hline Key: & W & Option weight \\
$\mathrm{R}$ & Feature ranking or rating \\
W*R & Option feature score \\
PCR & MSE-Retech plasma centrifugal reactor system \\
MIT & PNL-MIT-EPI/T\&A dc reactor system \\
USBM & INEL-USBM ac 3-phase melter system \\
IRCD & INEL IRC arc melter sized up to pilot-scale \\
PL.Hth. & SAIC-Retech plasma hearth melter system \\
\hline
\end{tabular}

\begin{tabular}{|c|c|c|c|c|c|c|c|c|c|}
\hline Melter option & $\mathbf{W}$ & $\mathbf{R}$ & $\mathbf{W} \cdot \mathbf{R}$ & PCR & MTT & USBM & IRCD & Pl.Hth & $\operatorname{Max}$ \\
\hline Melter containment & 0.6 & & & & & & & & \\
\hline (1) Skull/ref. & & 0.7 & 0.42 & 0.42 & & 0.42 & 0.42 & & 0.42 \\
\hline (2) Refractory & & 0.3 & 0.18 & & & & & & \\
\hline (3) Graphite & & 0.1 & 0.06 & & 0.06 & & & & \\
\hline (4) Cold wall & & 0.1 & 0.06 & & & & & 0.06 & \\
\hline Cooling & 0.5 & & & & & & & & \\
\hline (1) Gravity water & & 1.0 & 0.50 & & & 0.50 & & & 0.50 \\
\hline (2) Forced water & & 0.4 & 0.20 & 0.20 & & & 0.20 & 0.20 & \\
\hline (3) Forced air & & 0.1 & 0.05 & & 0.05 & & & & \\
\hline Cold cap & 0.7 & & & & & & & & \\
\hline (1) Thick & & 0.5 & 0.35 & & & & & & \\
\hline (2) Thin & & 0.7 & 0.49 & & 0.49 & 0.49 & 0.49 & 0.49 & 0.49 \\
\hline (3) None & & 0.2 & 0.14 & 0.14 & & & & & \\
\hline Tap or pour method & 0.2 & & & & & & & & \\
\hline (1) Tap separately & & 1.0 & 0.20 & & 0.20 & 0.20 & 0.20 & & 0.20 \\
\hline (2) Tap together & & 0.2 & 0.04 & 0.04 & & & & 0.04 & \\
\hline (3) Pour together & & 0.2 & 0.04 & & & & & & \\
\hline Redox state & 0.5 & & & & & & & & \\
\hline (1) Oxidizing & & 1.0 & 0.50 & 0.50 & & 0.50 & 0.50 & 0.50 & 0.50 \\
\hline (2) Neutral & & 0.5 & 0.25 & & & & & & \\
\hline (3) Reducing & & 0.1 & 0.05 & & 0.05 & & & & \\
\hline Arc length & 0.5 & & & & & & & & \\
\hline (1) Short & & 1.0 & 0.50 & & 0.50 & 0.50 & 0.50 & & 0.50 \\
\hline (2) Medium & & 0.5 & 0.25 & 0.25 & & & & & \\
\hline (3) Long & & 0.0 & 0.00 & & & & & 0.00 & \\
\hline Electrodes & 0.7 & & & & & & & & \\
\hline (1) Plasma torch & & 0.3 & 0.21 & 0.21 & & & & 0.21 & \\
\hline (2) Graphite & & 0.7 & 0.49 & & 0.49 & 0.49 & 0.49 & & 0.49 \\
\hline Power & 0.1 & & & & & & & & \\
\hline (1) dc & & 0.7 & 0.07 & 0.07 & 0.07 & & 0.07 & 0.07 & 0.07 \\
\hline (2) ac & & 0.5 & 0.05 & & & 0.05 & & & \\
\hline Chamber & 0.3 & & & & & & & & \\
\hline (1) Rotating & & 0.3 & 0.09 & 0.09 & & & & & \\
\hline (2) Tiltable & & 0.5 & 0.15 & & & & & & \\
\hline (2) Fixed & & 0.7 & 0.21 & & 0.21 & 0.21 & 0.21 & 0.21 & 0.21 \\
\hline Electrode configuration & 0.3 & & & & & & & & \\
\hline (1) 4-dc above melt & & 0.3 & 0.09 & & & & & & \\
\hline (2) 3-ac above melt & & 0.4 & 0.12 & & & 0.12 & & & \\
\hline (3) 2-dc above melt & & 0.5 & 0.15 & & & & 0.15 & & 0.15 \\
\hline (4) 1 top/1 bottom & & 0.4 & 0.12 & 0.12 & 0.12 & & & 0.12 & \\
\hline Th. Treat. prior to melter & 0.7 & & & & & & & & \\
\hline (1) None & & 0.3 & 0.21 & 0.21 & 0.21 & 0.21 & & 0.21 & \\
\hline (2) Thermal desorber & & 0.7 & 0.49 & & & & & & 0.49 \\
\hline (3) Pyrolyzer & & 0.5 & 0.35 & & & & & & \\
\hline (4) Mixed pyr/comb & & 0.7 & 0.49 & & & & 0.49 & & \\
\hline (5) Combustion & & 0.4 & 0.28 & & & & & & \\
\hline Total score & & & & 2.25 & 2.45 & 3.69 & 3.72 & 2.11 & 4.02 \\
\hline
\end{tabular}


Table 6-11. Qualitative ranking of melter systems with improved options.

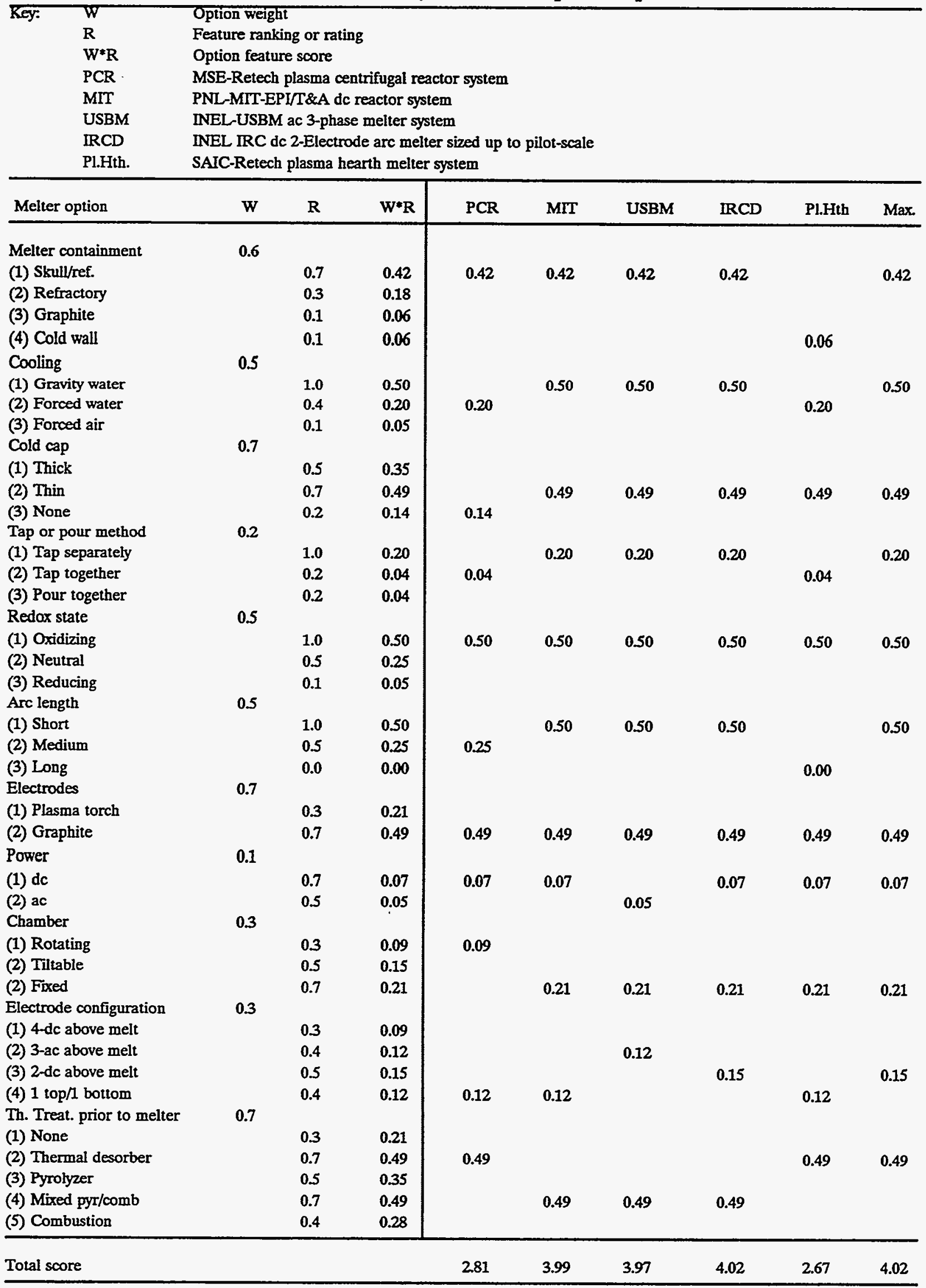


Table 6-12. Comparison of different melter system based on the different evaluation weighting systems.

\begin{tabular}{|c|c|c|c|c|c|c|c|}
\hline $\begin{array}{l}\text { Weighting } \\
\text { method }\end{array}$ & PCR & $\mathrm{MIT}$ & USBM & IRCD & Pl. Hth. & Pl. Hth. & Max. \\
\hline $\begin{array}{l}\text { Preliminary } \\
\text { weights }\end{array}$ & 0.578 & .0 .635 & 0.986 & 0.915 & 0.601 & 0.756 & 1.0 \\
\hline $\begin{array}{l}\text { Both AM. and } \\
\text { P.T. experts }\end{array}$ & 0.678 & 0.671 & 0.991 & 0.945 & 0.642 & 0.815 & 1.0 \\
\hline $\begin{array}{l}\text { Only A.M. } \\
\text { experts }\end{array}$ & 0.598 & 0.669 & 0.990 & 0.928 & 0.573 & 0.777 & 1.0 \\
\hline $\begin{array}{l}\text { Only P.T. } \\
\text { experts }\end{array}$ & 0.776 & 0.663 & 0.981 & 0.966 & 0.708 & 0.850 & 1.0 \\
\hline
\end{tabular}

The ranking of the melter systems, based on present or proposed options and features and the eight expert weightings, are as follows:

\begin{tabular}{clc} 
Rank & \multicolumn{1}{c}{ Melter System } & Scores \\
\hline 1 & USBM 3-phase ac arc melter & 0.991 \\
2 & INEL/IRC bench scale melter (up-scaled) & 0.945 \\
3 & SAIC/Retech plasma refractory/hearth melter & 0.815 \\
4 & MSE/Retech plasma centrifugal reactor & 0.678 \\
5 & PNL/MIT/EPI dc graphite melter & 0.671 \\
6 & SAIC/Retech plasma metal/hearth melter & 0.642
\end{tabular}

The same ranking is obtained when based on the plasma torch experts weighting values.

\subsection{Conclusions}

Calculations of melter geometry have shown that there is a significant difference in the footprint of the plasma arc melters considered. The size of the footprint is important in minimizing containment costs, maintenance, and D\&D costs. The melters with the smallest footprint per volumetric capacity are the dc axial graphite electrode and the dc plasma torch melters. Next, with a $20 \%$ increase in diameter, are the dc parallel graphite electrode, the ac 3-phase, and dc concentric graphite electrode melters. The dc rotating melter would have approximately double the diameter of the smallest melter. A short or submerged arc minimizes energy losses to the side walls and top and suffers no effective loss in heating duration because of the relatively high resistance of the slag.

The major design issues have been identified, options weighted for importance, and option features weighted for ranking. Evaluation of existing and potential demonstration melter systems 
indicate that the best choices are refractory lined melters with graphite electrodes (ac, 3-phase or dc). Alone, in second place, is the plasma hearth melter with a refractory lining. Improvements in several systems can be made by going to a refractory lining and replacement of the torch with a graphite electrode. 


\section{OFFGAS SYSTEM DESIGN CONSIDERATIONS}

Controlling the emissions of radionuclides, toxic metals, and organics is one of the most important environmental, regulatory, and public acceptance issues for mixed waste treatment. The formation of offgas during the treatment of mixed wastes is unavoidable in practice because, regardless of treatment technology used, these treatment objectives must be met:

- Radionuclides and toxic metals must be immobilized in a durable, nonleachable waste form

- Hazardous organics must be immobilized or destroyed

- The volume of the final waste form must be minimized

- The waste form must be homogeneous and readily characterized.

Arc melting meets these objectives by thermally decomposing and eventually oxidizing the organics and melting the inorganic components into homogeneous molten slag or molten metal. Upon cooling, the molten slag forms a durable, leach-resistant glass or ceramic, and any metal may be recycled or separately disposed. This process results in offgas formed from the decomposition and oxidation of volatile and organic materials in the waste. The amount of offgas generated is minimized by using electrical heating of the melter rather than fossil-fired heating common to incinerators, and by using oxygen for combustion rather than air.

\subsection{Design Offgas Composition and Flowrate Requirements}

The offgas will vary in composition and flowrate, depending on (a) the input waste stream chemical and physical properties, variability, and heterogeneity, and (b) incinerator and melter design and operating conditions. Complete, efficient oxidation of gaseous decomposition products is not expected in incineration and vitrification processes, so an afterburner is included in the process downstream of the melter to fully oxidize the offgas to meet expected RCRA, TSCA, and other requirements. Results of mass balances, energy balances, and equilibrium calculations used to predict the afterburner outlet gas compositions are summarized in Table 7-1 and are shown in more detail in Appendix D for seven different feed mixtures that represent different waste categories stored at the INEL Transuranic Storage Area at the Radioactive Waste Management Complex. These compositions and flowrates are based on using oxygen instead of air for combustion in an incinerator and a melter, and on both being vented to a shared afterburner that also uses oxygen for combustion. The gas compositions and flowrates vary significantly for the different feed types and feedrates.

Flowrates through the incinerator, melter, and afterburner were modelled using the Incinerator-Melter Process Simulation (IMPS) model. In this model, chemical reactions are defined by the user, and degrees of completion for competing reactions (such as the consumption of oxygen in the oxidation of volatile organics, fixed carbon, and elemental metals in the feed) are based on free energy values at $1500^{\circ} \mathrm{C}$. Equilibrium levels of such species as gaseous metal chlorides were computed using Pyrosim, a Gibbs free energy minimization model. 
Table 7-1. Summary of predicted offgas flowrates and compositions. ${ }^{a}$

\begin{tabular}{ll}
\multicolumn{1}{c}{ Parameter } & \multicolumn{1}{c}{$\begin{array}{c}\text { At thermal oxidizer } \\
\text { outlet location }\end{array}$} \\
\hline Flowrate, $\mathrm{kg} / \mathrm{hr}$ & $1,300-9,400$ \\
Flowrate, $\mathrm{scfm}$ & $470-3,100$ \\
Oxygen, vol\% & $1-3.5$ \\
Carbon dioxide, \% & $2.3-8.9$ \\
Carbon monoxide, ppm & 10 \\
Hydrogen, ppm & 0 \\
Hydrochloric acid, ppm & $72-34,000$ \\
Chlorine, ppm & $0-170$ \\
Sulfur dioxide, ppm & $0-1,200$ \\
Water vapor, \% & $5.8-76$ \\
Total particulate matter, $\mathrm{kg} / \mathrm{hr}$ & $10-50$ \\
Total particulate matter, $\mathrm{mg} / \mathrm{dscm}$ & $500-2,500$
\end{tabular}

a. For a waste feedrate to the incinerator/melter of $1,000 \mathrm{~kg} / \mathrm{hr}$ for the $\mathrm{G} 1, \mathrm{M1},(5, \mathrm{P}, \mathrm{S}, \mathrm{HD} 1$, and Nom60 waste mixtures.

Rudimentary heat balances have been prepared to compute the amounts of (a) added carbon dioxide, if any, needed for cooling the incinerator and afterburner when feeding high-heating value material, and (b) added oxygen and auxiliary fuel (natural gas) needed to add heat to the incinerator and the afterburner when the heat content of the waste or the offgas is not sufficient to maintain the design operating temperatures. $\mathrm{CO}_{2}$ or recycled offgas (which is mostly $\mathrm{CO}_{2}$ when oxygen is used for combustion rather than air) is the assumed cooling gas. It is assumed that this cooling $\mathrm{CO}_{2}$ will be premixed with the combustion $\mathrm{O}_{2}$.

Operating temperatures were set at $1000^{\circ} \mathrm{C}$ for the incinerator, $1800^{\circ} \mathrm{C}$ for the melter, and $1200^{\circ} \mathrm{C}$ for the afterburner. Design oxygen stoichiometries for complete combustion were approximately $60 \%$ for the incinerator, $10 \%$ for the melter, and $110 \%$ for the afterburner. Actual stoichiometries varied somewhat from these design levels. Gaseous effluents from the afterburner were assumed to be efficiently oxidized, with nominal expected levels of $C O(10 \mathrm{ppm})$ and unburned hydrocarbons (1 ppm).

Entrained particulate from both the incinerator and the melter in the offgas to the afterburner, was assumed to be $1 \%$ of the initial incinerator waste feedrate. The entrained feed particles may "short-circuit" through the high-temperature gas regions and may still be similar in physical properties and chemical and radiological composition to untreated feed fines. 
The equilibrium amounts and composition of volatilized particulate were computed at the incinerator and melter conditions using Pyrosim.

Offgas compositions and flowrates at various locations in the offgas system were calculated using a simple spreadsheet (Appendix D) that includes heat and mass balances for the different offgas unit operations downstream of the afterburner. This spreadsheet also calculated the amounts of added streams (cooling water, cooling gas, baghouse purge gas, etc) and the amounts of secondary products (cyclone and baghouse residues, scrubber blowdown, condensed water from cooler, etc). Control efficiencies and operating conditions were estimated where necessary.

A preliminary offgas system design was based on a few basic requirements:

- $\quad$ Operate very reliably with minimal downtime and upsets.

- Control emissions of gaseous organics, radionuclides, toxic metals, particulate, and acid gases to meet expected regulatory limits.

- Tolerate offgas flowrate and composition variations from the incinerator and melter processes.

- Meet goals for the secondary streams to maximize recycle, minimize volumes and masses, and avoid mixed waste scrubber solutions.

Expected control efficiencies and emission limits are shown in Table 7-2. These limits were developed for the Integrated Thermal Treatment System Study (ITTS) (Feizollahi et al. 1994), and have been updated based on information from the offgas subcommittee. There may also be emission limits for total particulate and various radionuclides (especially TRU elements and others thought to be in the waste). The limit for these radionuclides will probably be the detection limit of continuous or semicontinuous instrumentation.

Other relevant issues include containment/control of offgas during the failure of a downstream unit (such as the wet scrubber), criticality concerns, and worker exposure during routine operation and during routine and nonroutine maintenance.

\subsection{Overview of a Preliminary Design that Meets the Requirements}

The main components of the offgas system, with associated process flowrates, are shown in Figure 7-1. The main offgas units include the following:

- Afterburner, fossil-fuel fired

- Partial quench using water spray, with air atomization for the water

- Controlled damper for back-pressure control 
Table 7-2. Potential emission limits for various pollutants.

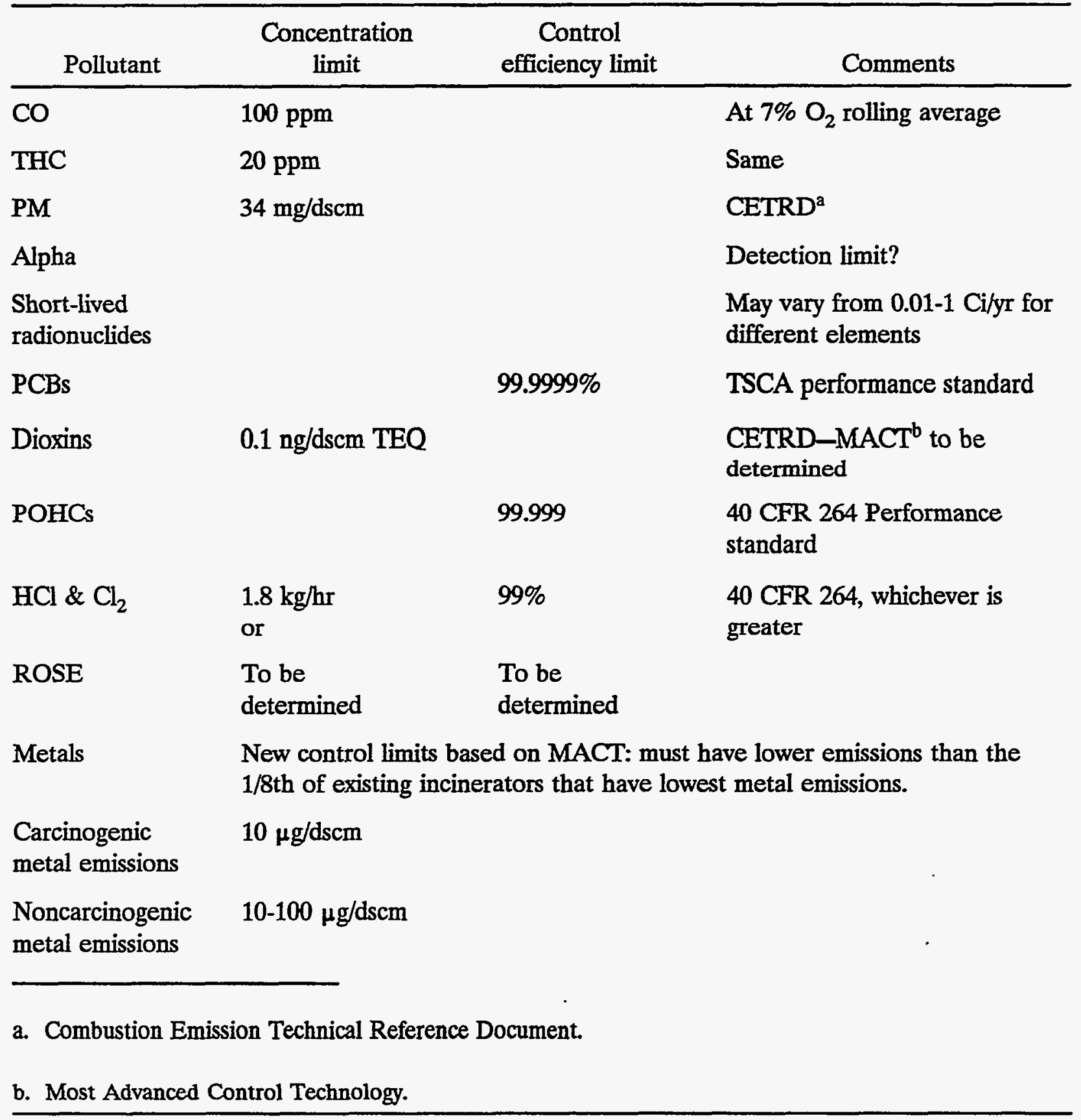

- Air quench, to ensure sufficient cooling and temperature control, while minimizing the potential for incomplete water vaporization

- Cyclone/spark arrester

- Baghouse for particulate and solid radionuclides

- Total quench and wet scrubber for acid gases

- Reheater for raising gas above dewpoint (electric resistance heating) 


\section{三人lockheed}

Idaho Technologles Company

Idaho Waste Treatment Program - Preliminary Design

January 30, 1995

$\therefore$

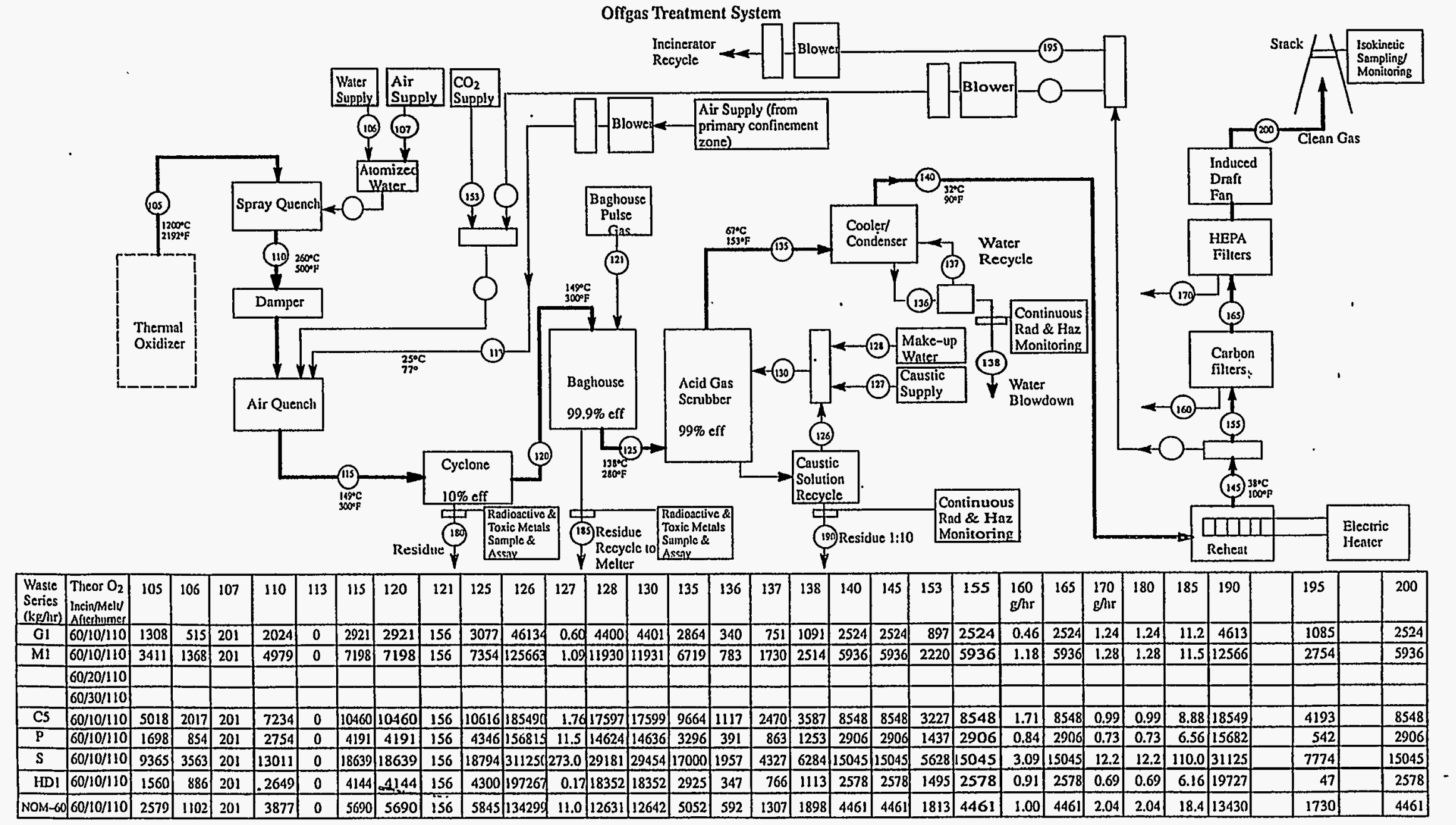

Figure 7-1. Offgas Treatment System. 
- Recycle for air quench, melter temperature quench, kiln seals pressurization, etc

- Carbon filters for $\mathrm{Hg}$, VOCs, semi-VOCs

- HEPA filters for final filtration

- ID fan with controlling damper

- Vent to atmosphere.

This system is very similar to systems included in the ITTS preliminary designs and lifecycle cost estimates, the preferred system design from the Mixed Waste Integrated Program pilot-scale plasma hearth process (Dalton, Wolfe, and Geimer 1994), and the system designed for the U.S. Bureau of Mines arc melter test facility being used for Buried Waste Integrated Demonstration tests (Soelberg et al. 1994).

No $\mathrm{CO}_{2}$ absorption/recovery is included in this baseline, but it may be added if necessary. Cost evaluations done for the ITTS have shown that the incremental cost of using $\mathrm{CO}_{2}$ absorption (for controlling $\mathrm{CO}_{2}$ emissions and for implementing "zero emissions" or "closed loop" operation) is a very small portion of the total lifecycle cost of a treatment facility.

The zero emissions option is not included in this baseline case, but this may be added by including (a) continuous gas, particulate, and radiation monitoring, (b) retention chambers, and (c) $\mathrm{CO}_{2}$ absorption.

Other features not included in this preliminary design include (a) containment/control of offgas during failure of an offgas system component, and (b) $\mathrm{NO}_{x}$ control equipment or reagents. $\mathrm{NO}_{x}$ control measures may be needed for processing wastes that contain high levels of nitrates. Separate dampers, quench sections and retention tanks may be features included in the future for controlling and containing emissions during offgas equipment failures.

Each of the primary offgas units is discussed in the following sections.

\subsection{Afterburner}

The primary requirement is that the time, temperature, and mixing must be sufficient for hydrocarbon destruction and meet permit requirements. To be conservative, limits for destroying PCBs and dioxins at an efficiency of $99.9999 \%$ was assumed even though PCBs and dioxins are not likely to be present in the waste. The time/temperature requirement for PCB destruction from the Toxic Substances Control Act is two seconds residence time at $1200^{\circ} \mathrm{C}$. For the calculations in Appendix D, an afterburner oxygen stoichiometry of $110 \%$ was assumed.

The afterburner must also tolerate variations in the input gas flowrate, temperature, and composition. The flowrate from the melter/incinerator combination may vary by as much as $1: 7$ for the different feed mixtures that have been evaluated, at relatively constant waste feed input. This amount of variation (turndown) may be modulated by using recirculated offgas. The more ideal turndown for the afterburner and for the downstream offgas control equipment is 1:2. This 
reduced degree of turndown may also be achieved by varying the waste feedrate for different feed mixtures according to their relative heat content or volatiles content.

Auxiliary heat may be provided by fossil fuel combustion or by electric torches. In the baseline case, natural gas firing is used. Use of electric torches in this application is not sufficiently developed and demonstrated to be used in the baseline case.

Other options include using air, $\mathrm{O}_{2}$, or $\mathrm{O}_{2}$-enriched air for offgas combustion and for combustion with the fuel from the natural gas burners. In the baseline case, pure oxygen is used to provide combustion oxygen. When $\mathrm{CO}_{2}$ or recycled offgas is used for cooling the incinerator or the afterburner, it is assumed that this cooling $\mathrm{CO}_{2}$ will be premixed with the combustion $\mathrm{O}_{2}$.

Maintenance issues include refractory wear and longevity, and slagging/fouling of surfaces. Afterburner geometry and refractory design should consider potential slagging and fouling of surfaces in the afterburner. Where possible, the operating temperature should be as low as possible (while meeting temperature requirements) to reduce auxiliary fuel consumption, thermal $\mathrm{NO}_{x}$ formation, and thermal effects on refractory and equipment. High alumina Ruby refractory has been satisfactory at temperatures around $1400^{\circ} \mathrm{C}$ in contact with slags from soil and surrogate additives.

Design and operation should also consider interactions and behavior of entrained and volatilized particulate, especially oxidation of reduced metal species such as metal chlorides, vaporization of entrained particulate, and others. There may be about $1 \%$ of the feed material entrained in the offgas along with volatilized fume (Soelberg, et al., 1994b). The entrained feed material may not experience the same time/temperature history expected in the melter or the kiln, and so may still contain carbonates, chlorides, etc. At the high afterburner temperatures, there may be some volatilization of the entrained feed material and reactions with the offgas and volatilized fume.

The baseline case includes one afterburner and offgas system for the incinerator and the melter. The most critical considerations for separate or combined afterburners and offgas systems are (a) relatively different offgas flowrates, temperatures, and compositions, (b) different levels of entrained and volatilized particulate, and (c) impact of pressure and flow fluctuations from the melter on the incinerator and visa versa through a combined afterburner. The capital and operating cost savings of a shared afterburner and offgas system may not be worth the possible mutual interference in operation of the melter and the incinerator. They may only be able to share the same exhaust stack, to have a single emission point, without mutual interference.

\subsection{Partial Temperature Quench}

The high temperature of the offgas exiting the afterburner must be reduced to enable downstream control of particulates, metals, and acid gases, and to prevent thermal damage of the downstream equipment. Requirements for the temperature quench include:

- Having sufficient control over the quench process to enable rapid response to temperature, flowrate, and composition variations of the offgas, in order to protect the baghouse from high-temperature excursions and also prevent cooling the gases below the water dewpoint. 
- Quenching as rapidly as possible to reduce residence time in the temperature range in which dioxins may be formed if dioxin precursors are present.

- Minimizing the potential for solid or liquid deposits that may impair offgas cooling or cause flow restrictions.

- Minimizing total offgas flowrate through the remainder of the system to reduce equipment size and to have lower flowrates of offgas out the stack.

Heat recovery, though normally a good practice to increase energy efficiency and reduce operating costs, is a very low consideration compared to the above criteria. Heat exchangers such as heat recovery boilers to perform offgas cooling were not included because of the (a) potential for process upsets due to fouling or corrosion of heat transfer surfaces, and (b) longer residence times in the dioxin-forming temperature window.

The quench operations selected for the preliminary design include an evaporative water spray quench and a dilution quench. The water spray quench is used to achieve the greatest portion of gas cooling, from up to $2400^{\circ} \mathrm{F}$ to around $500^{\circ} \mathrm{F}$, without using heat transfer surfaces that may foul, while minimizing the increase in the total offgas flowrate. The water spray must be evaporated, and the offgas must not be cooled to the water or acid dewpoint in the spray quencher, to prevent particulate and acid deposition and corrosion in the downstream sections. The water spray must have sufficient control to rapidly adjust to variations in the offgas conditions. The amount of spray quench to achieve a temperature decrease from $2400-500^{\circ} \mathrm{F}$ roughly doubles the total offgas flowrate, due to the vaporized water.

The air dilution quench was included to fine tune the offgas cooling to around $300^{\circ} \mathrm{F}$ to protect the baghouse, relieving the need for the water quench to approach the water or acid dewpoints too closely. The trade-off is that the total offgas flowrate roughly doubles again with the added diluent air. If oxygen is used in the upstream incineration, melter and afterburner processes, the total flowrates of the offgas, cooling water, and diluent air will decrease, but the flowrates of cooling water, and diluent air compared to the offgas flowrate will increase because the offgas will have a much higher level of $\mathrm{CO}_{2}$, and a higher heat capacity. Using cooled, treated offgas as the diluent instead of air in this case can reduce the relative amount of the diluent gas to be roughly the same as the offgas flowrate.

Even with the rapid quench to around $300^{\circ} \mathrm{F}$, recent studies have shown that there may still be some formation of dioxins in the quench process and in the baghouse. To prevent dioxin formation, the gas should be totally quenched to its dewpoint of around $130-180^{\circ} \mathrm{F}$. This would dictate using a different offgas control system, one that would exclude the baghouse for particulate, metals, and radionuclide filtration, and include wet scrubbing such as is accomplished by a free jet scrubber for both particulate and acid gas control. The main disadvantage of such an offgas control system is that the scrubber solution would be a mixed waste scrub solution containing particulate, hazardous metals, radionuclides, chlorides, and sulfates. This type of secondary waste stream requires further treatment before disposal. Criticality is also a potential issue that must be evaluated with respect to transuranic radionuclides in a water medium. 


\subsection{Particulate and Radionuclide Control}

Depending on the feed material and on operating and design conditions of the incinerator/melter, there may be significant amounts of particulate matter entrained in the offgas. This particulate matter will include, in various proportions, the following:

- Dust from the feed material that is entrained in the offgas without coming into contact with the molten slag in the melter. This dust may have bypassed the high-temperature melt zone and may be similar in composition and physical properties to the corresponding dust in the feed material.

- Fume formed from volatile particulate that volatilized from the melt or from entrained particles in the afterburner section, and condensed upon cooling in the partial quench section to form aerosols and coatings on other entrained particles.

- Volatile material that has not yet condensed at the lower gas temperatures exiting the partial quench section.

In mixed waste treatment, this particulate may include (a) toxic metals and radionuclides that are present in feed dust that is entrained and (b) toxic metals and any radionuclides that are volatilized or otherwise entrained from the melt into the offgas. Requirements for particulate and radionuclide control include

- Meeting expected emission limits

- Minimizing the amounts of offgas secondary streams that are radioactive

- Minimizing amounts of dispersible (dusty) secondary streams

- Optimizing the handling and treatability of the secondary streams, including avoiding liquid mixed waste streams and maximizing recycle.

A pulse-jet baghouse was selected for the preliminary design based on the high control efficiencies for baghouses, and because the large majority of radionuclide and toxic metalcontaining particulate is captured in a dry, readily recycled or treated secondary stream. However, this secondary stream will contain significant amounts of dispersible dust that will require positive containment. The secondary stream will require further treatment to contain the fines and immobilize radionuclides and toxic metals.

A cyclone is placed upstream of the baghouse to serve as a spark arrestor and to remove any large particulate upstream of the baghouse. This cyclone may be unnecessary during routine operation but may be useful to protect the baghouse during system upsets when there may be large amounts of particulate carryover.

Important issues include worker exposure and containment of dusty contamination during inspections and routine maintenance of the baghouse, such as during bag changing. This is especially important for containment of alpha particles that may have been entrained in the offgas and collected in the baghouse. A design similar to that used for the baghouse for the INEL 
Waste Experimental Reduction Facility incinerator may improve worker exposure and contamination control.

Much of the material collected in the cyclone and in the baghouse may be recyclable. The recycle amount will be limited to the amounts of volatile metals such as lead and zinc that will be collected in the baghouse residue, but are readily volatilized from the melter. As baghouse residue is recycled, the concentrations of these metals will increase. Some proportion of the baghouse residue must be removed and not recycled in order to enable removal of these species from the system.

Potential strategies for immobilizing the cyclone/baghouse secondary stream include producing a low-temperature glass, portland cement, and sulfur-polymer cement. Each of these waste forms has advantages and disadvantages. Based on results of arc melter demonstration tests (Soelberg, et al. 1994b), this secondary stream may contain from 1-50 wt\% $\mathrm{Cl}$ in addition to toxic metals and small amounts of radionuclides. TRU elements may be present if TRU is a contaminant in the feed dust fines that are entrained, or if the volatility of TRU under the melter/incinerator conditions is significant. A glass waste from such as borosilicate glass may be produced at relatively low temperatures to reduce the volatility of metals and radionuclides and efficiently immobilized these species in the glass. However, the chlorides are more difficult to retain in the glass, so a tertiary waste stream will be produced that will contain these chlorides and any other volatile materials not retained in the glass.

Portland cement is a proven, low-temperature waste form, but portland cement is not compatible with large amounts of chlorine. This may result in relatively low waste loadings, increasing the amounts of portland cement and the final waste volume. The increased final waste volume may be minimal with respect to the entire treatment system, because of the expectedly small amount baghouse/cyclone residues compared with the total amount of waste being treated.

Sulfur-polymer cement has more potential for immobilizing sulfur- and chlorine-containing wastes, but sulfur-polymer cement has not been widely proven.

\subsection{Acid Gas Control}

Acid gases, including $\mathrm{HCl}$ and $\mathrm{SO}_{2}$, will be produced from waste materials that contain chlorides and sulfates. Requirements for acid gas control include:

- Meeting expected control efficiency and emission limits

- Minimizing the amounts of offgas secondary streams that are radioactive

- Optimizing the treatability of the secondary streams, including avoiding liquid mixed waste streams

- Having minimal impact on system backpressure and flowrates.

Wet scrubbing using a packed bed scrubber downstream of the baghouse was selected. A total quench to the saturation temperature is necessary at the inlet to the scrubber. Packed bed scrubbers are reliable and can have large turndown ratios compared to some other scrubbing 
designs. Assuming that the baghouse can efficiently filter particulate and radionuclides, the scrubber blowdown may be below regulatory limits for toxic metals and radionuclides, though it will contain high chloride levels from some waste streams. Continuous analysis of the blowdown for toxic metals and radioactivity is expected to be required. If this stream is not considered radioactive, more routine treatment and handling of this secondary stream is possible.

The best handling and disposal strategies may be solidification in portland cement. Like the baghouse residues, the large amounts of chlorine may require low waste loadings to ensure an acceptable waste form. Alternative handling/disposal options may include reducing the liquid volume by evaporation or removing dissolved ions by ion exchange, complexation, or other techniques. These other techniques will produce tertiary wastes, such as spent ion exchange resin.

The scrubber gas outlet temperature may be tailored to optimize the absorption efficiency of the downstream charcoal absorber.

\subsection{Offgas Cooling}

The assumed scrubber gas exit temperature for the baseline shown in Figure $7-1$ is $153^{\circ} \mathrm{F}$. Assuming a temperature limit for the downstream carbon filters of $120^{\circ} \mathrm{F}$, a secondary cooler/condenser may be needed, and was included. The cooling is achieved by heat transfer from the gas to heat water from 60 to $130^{\circ} \mathrm{F}$ (a $23^{\circ} \mathrm{F}$ approach temperature in this counter-current design). Water is condensed out of the gas stream to the saturation level of around 5 vol\%. Alternatively, heat may be removed by using a heat exchanger on the scrubber liquor recycle line to eliminate the need for the cooler/condenser. In a waste treatment process, this will be done to eliminate the cooler/condenser and the associated secondary waste stream.

\subsection{Trace Organics and Mercury Control}

Mercury and trace organics such as dioxins, if present in the offgas, are not efficiently controlled in the upstream baghouse and wet scrubber. Most of the waste contains no mercury and very small amounts of chlorinated organics, but the system must be able to handle those few waste streams that do contain dioxin precursors, and may contain small amounts of mercury and PCBs that cannot be segregated. Also, dioxins may be formed in small amounts in the baghouse, even at temperatures as low as $300^{\circ} \mathrm{F}$. In order to meet expected emission limits while feeding these waste streams, mercury and trace organic emissions must be controlled by carbon absorption.

Levels of these contaminants will vary significantly for the different waste types and will depend on upstream equipment design and operating conditions. The preliminary design for the offgas system assumes an operating temperature of $115^{\circ} \mathrm{F}$ and a maximum temperature of $120^{\circ} \mathrm{F}$. This is a conservative temperature for efficient control of trace mercury and dioxins.

The spent charcoal will be a secondary waste. Spent charcoal that does not contain significant amounts of $\mathrm{Hg}$ may be recycled to the melter, even if small amounts of dioxins and other organics are present. The melter and the afterburner are designed to destroy these organics. Large amounts of $\mathrm{Hg}$ will not be efficiently retained in the slag or other secondary 
wastes, and so may build up in the system if spent charcoal containing large amounts of $\mathrm{Hg}$ are recycled.

\subsection{HEPA Filtration}

The baghouse is assumed to be $99.9 \%$ efficient for particulate. The wet scrubber may be very inefficient at controlling the remaining $0.1 \%$, and additional particulate may form owing to the drop in offgas temperature downstream of the baghouse. In a nuclear environment, it is expected that final HEPA filtration will be required to control this small potential amount of remaining particulate for radionuclide and toxic metals control.

Spent HEPA filters will also be a secondary waste, which may be recycled to the melter, processed in a low-temperature glass melter, or macroencapsulated. Recycle to the melter is the best option, as long as there is not a large buildup of $\mathrm{Hg}$ or difficult-to-control fines in the system.

\subsection{Vent to Atmosphere}

Operation with zero emissions may be required in order to meet regulatory and public concerns. This is not included in this case, but the use of oxygen instead of air for combustion in the incinerator, melter, and afterburner, and the use of recycled offgas for dilution quenching and for pulsing the baghouse will significantly reduce the flowrate of offgas. In this scenario, the majority of the offgas will be carbon dioxide, with a few percent water vapor. There will be small amounts of nitrogen and oxygen from air inleakage, ppm levels of various pollutants, including $\mathrm{CO}, \mathrm{NO}_{x} \mathrm{HCl}$, and $\mathrm{SO}_{2}$ and $\mathrm{ppb}$ or lower levels of some VOCs. Continuous monitoring for gas composition, particulate and metals emissions, and radioactive emissions is expected to be required.

The general intent of zero emissions may be achieved by ensuring that no unanalyzed offgas and no offgas that exceeds emission limits is emitted. This may be done by continuously monitoring for gaseous, radioactive, and particulate emissions, or by absorbing the $\mathrm{CO}_{2}$ in a $\mathrm{CO}_{2}$ scrubber, or by containing the remaining offgas in containment vessels. Following semicontinuous or slow response time analysis, the vessels may be vented to the atmosphere. The contents of any vessels that do not meet emission limits would be treated by recycle back to the offgas system or to a separate treatment system.

Relevant issues yet to be resolved include (a) the availability and reliability of continuous monitoring equipment, (b) the subsequent handling of carbonates from the $\mathrm{CO}_{2}$ scrubber (analysis followed by calcination to regenerate the absorbent, or land disposal), and (c) treatment of offgas that exceeds emission limits. 


\section{CONCLUSIONS AND RECOMMENDATIONS}

\subsection{Introduction}

The Advanced Mixed Waste Treatment Project (AdvMWTP) invited thermal processing and offgas treatment experts representing many DOE projects, consultants, and engineering firms in the United States and Europe to participate in a melter system preliminary design technical review meeting in October 1994. It was a very timely meeting to discuss thermal treatment of mixed radioactive waste. DOE is supporting a wide variety of programs to develop processes for mixed and radioactive waste.

The purpose of the meeting was twofold:

1. Conduct an objective evaluation of thermal treatment processing options for alphacontaminated mixed low-level radioactive waste.

2. Provide feedback on the thermal treatment process preliminary design so that the AdvMWTP could proceed with the next phase of design.

The results from the melter system preliminary design technical review meeting will guide the AdvMWTP in selecting a system configuration for planned design and demonstration activities in FY 1995 through FY 1997. Since the October meeting, INEL Waste Management funding (EM-30) for the AdvMWTP thermal treatment process development has been put on hold by Lockheed Idaho Technologies Company (LITCO) to evaluate potential integration of EM-30 and Office of Technology Development (EM-50) funding and projects.

INEL engineers presented their evaluations and preliminary designs for the following thermal treatment processing topics:

- $\quad$ Plasma arc melters

- Off-gas treatment

- Overall system configuration and issues.

A Technical Advisory Committee comprised of a diverse group of thermal processing and offgas treatment experts had been invited to provide comments, discuss issues, and provide objectivity. The committee was divided into subcommittees to address the three topics of design presented at the meeting. All personnel attending were encouraged to ask questions, stimulate discussion, and comment on the presentations.

The main advantage and strength of a technical review using this format, and what made this meeting a success, was the great diversity of personnel attending the meeting. DOE contractors, consultants, and engineering firms represented competing programs, melter system vendors, and thermal processing without radioactive waste treatment experience. It is under such conditions of 
diversity, conflicting drivers, and varying goals that one sees the initiation of a paradigm shift toward new ideas and concepts, and doors opening for new insights.

The chair and co-chair for each subcommittee was responsible for summarizing the discussions, providing recommendations, and noting all unresolved issues. The following are edited versions of the Technical Advisory Committee responses for each design topic. The full unedited versions of the their responses are presented in Appendices A, B, and C.

The extensive review for the melter system design for processing ALLW/TRUW at the INEL included the following:

1. Prior DOE technology development projects that contributed to the present stage of design by the AdvMWTP.

2. Relevant industrial and commercial plasma arc melter applications that may affect the design.

3. The composition and heterogeneity of the input waste streams, slag chemistry, and final waste forms.

4. The proposed overall system design, denoting issues that need to be solved, options, flow sheets, the effect of the heterogeneity of the waste streams of the component design, and whether an incinerator is needed.

5. An effect of using different melter configurations on the melter and confinement structure size, as well as the evaluation of melter systems based on options available.

6. A presentation and discussion of the proposed offgas system and the design issues of preferred location and type of various components.

The main topics of discussion are summarized below, followed in each section by recommendations. Other critical topics, such as feed preparation and handling or monitoring and control were not within the scope of this meeting.

\subsection{Plasma Arc Melter Design}

The melter subcommittee had the explicit task to recommend a particular melter design and features of that design. Various melter designs are commercially available, and the committee has experience in their operation, and, given the constraints presented, should be able to make explicit recommendation.

The subcommittee reminded us that mineral wool production made in 3-phase, ac arc melter is an existing industrial process in which compositions similar to those in the RWMC are melted and transferred at high temperature to the wool forming machinery.

The incinerator, as referred to herein, should be excluded from the design because of the extra material handling, the additional complication of another component and its control, and if 
it is found to be unnecessary, so much the better. A larger melter then usual would be required to handle this greater than original combustible content.

Elimination of the incinerator requires more homogeneity in the sizing of the feed to minimize variations in processing; therefore, the maximum feed size should be related to the size of the melter or feed tubes. Classifying and shredding to less than a 4-inch particle size is recommended for the melter size proposed.

The melter recommended is a 3-phase ac melter (in agreement with the results of Section 6). The basis is reduced maintenance in electrode life, reduced maintenance inside the melter because there is no bottom electrode, and added reliability in eliminating potential eruptions from undetected leaks from water sources. A 4-m (3-5-m) diameter melter is recommended in order to smooth upsets and make the melt more homogeneous with the heterogeneous feeds. A 2-MW power capability is recommended for a feed rate of 1-ton/h. (This is about double the more ideal power rate of $1 \mathrm{kWh} / \mathrm{kg}$, and allows for more significant heat losses.) A refractory lining with gravity or forced water would provide a skull for long refractory life and low maintenance. Cold cap operation with electrodes submerged into the molten slag is recommended. (The effect on the redox ratio needs to be checked in bench-scale experiments.) Dual slag and metal tap holes are recommended for reliable plant operation.

When considering criticality issues in the larger 4-m-diameter melter proposed, the subcommittee indicated that a smaller melter could be used. This may require a less crowded melter top, and the Retech fixed hearth melter may be appropriate. (The 3-phase, ac melter requires three electrode openings and several feed tube openings in the melter top.) The subcommittee did not recommend whether the fixed hearth should be used with a plasma torch or a graphite electrode, nor indicate the impact of the bottom electrode.

Control of the desired oxidizing redox state in the slag by iron ore rather than a more disruptive oxygen lance was preferred, even though the volume reduction factor would be reduced. Even with a high oxidation potential in the melter, the subcommittee did not believe the graphite electrode consumption would be excessive.

Control of the melter was recognized as a major problem. One recommendation was to tap the slag continuously, and monitor its temperature and viscosity.

In general, the subcommittee's recommendations are in concert with the results of the melter system design evaluation in Section 6.

\subsection{Offgas System Design}

Review of the entire system, including the offgas system, was considered very timely at this stage in the AdvMWTP development because of the importance of getting stakeholders involved early in the process. Stakeholders include the public, local and state governments, and regulatory agencies. Support will be needed from such government groups as the Western Governors' Association DOIT Committee. Regulatory permit writers need to be involved early to educate the AdvMWTP working team of their constraints relative to technologies and permitting. The AdvMWTP team needs to also educate the permit writers about the system and designs, and 
identify potential gaps in information or data that will be required to do facility design and obtain permits.

There are two general offgas system designs that are best suited for controlling acid gas and particulate emissions from mixed-waste treatment processes. These are the dry-wet and the wetdry systems. The dry-wet system is used to remove particulate (including most of the toxic metals and radionuclides) in a dry secondary stream that may be partially recycled to the melter or immobilized for final disposal. In the dry-wet system, the acid gases (primarily $\mathrm{HCl}$ and $\mathrm{SO}_{2}$ ) are removed by wet scrubbing following the particulate removal. In the wet-dry system, all contaminants, including particulate, radionuclides, toxic metals and acid gases, are wet scrubbed and produce a single secondary aqueous mixed waste with some suspended and dissolved particulate material.

\subsubsection{Dry-Wet Offgas System}

There was significant discussion and contribution from the Technical Advisory Committee and, especially, the offgas subcommittee on the offgas system. The subcommittee considered the proposed offgas system (Appendix D) to be conservatively selected and that the equipment selected was state of the art. The proposed system represents a dry-wet system, where the hot afterburner offgas is partially quenched to a temperature of around $300^{\circ} \mathrm{F}$ and then filtered in a baghouse to remove particulates. The offgas temperature is not reduced to the dew point, and there should be no moisture or acid gas condensation. This dry filtration is then followed by a wet scrubbing that includes a total quench to the offgas dew point and wet acid gas scrubbing. Following this step, the offgas is reheated to a temperature above the dew point for charcoal filtration of trace mercury and organics, and is subjected to final HEPA filtration of any remaining particulate.

This dry-wet system meets the following offgas treatment requirements:

- Operates very reliably with minimal downtime and upsets

- Controls emissions of gaseous organics, radionuclides, toxic metals, particulate, and acid gases to meet expected regulatory limits

- Tolerates offgas flowrate and composition variations from the incinerator and melter processes

- Meets goals for the secondary streams to maximize recycle, minimize volumes and masses, and avoid mixed waste scrubber solutions.

However, there are two potential concerns with this system. The first is that the baghouse will contain fine, easily dispersed particulate matter that will contain chlorides, toxic metals, and, potentially, alpha-contaminated particles. These fines will be difficult to control and will be a contamination hazard during baghouse maintenance and handling of this secondary stream. The primary issue that needs to be resolved is the trade-off between mutually exclusive objectives or requirements for particulate control: minimizing amounts and maximizing treatability of secondary streams versus controlling dispersible fines. The baghouse residues represent a secondary stream 
that can be at least partially recyclable, and the remainder can be readily immobilized and disposed using conventional portland cement (with waste loading limits based on the tolerance for chlorides) or the more innovative sulfur-polymer cement, which may be more tolerant to chlorides.

The alternative to dry filtration for particulate control is wet particulate scrubbing, which results in an aqueous secondary stream containing dissolved and suspended particulate matter, sludge, chlorides, toxic metals, radionuclides, and chlorides. During secondary handling and treatment, this aqueous secondary stream will readily control fines. Key disadvantages of such an aqueous waste stream include that (a) this secondary stream is a wet, 2-phase mixture with mixed hazardous and radioactive contaminants, (b) the stream has a larger mass flowrate compared to a secondary stream of only baghouse residues, (c) the aqueous stream cannot be readily recycled without some additional treatment such as drying, and (d) the stream cannot be immobilized using sulfur polymer cement without completely drying the residue. Any drying step for this aqueous stream will result in an undesirable dispersible fines scenario similar to that of dry baghouse filtration. The wet-dry system also needs a safety analysis to evaluate the potential for criticality concerns in the scrubber solution.

The second concern is the potential for dioxin formation at the relatively low temperatures of baghouse filtration. Until recently, temperatures in the $300^{\circ} \mathrm{F}$ range were thought to be below the temperature window in which dioxins could be formed from dioxin precursors. Recent monitoring and control efforts within industry indicate that the $300^{\circ} \mathrm{F}$ range may not be low enough. Also, new, very low ( $0.1 \mathrm{ng} / \mathrm{dscm}$ Toxicity Equivalent for PCDD) emission limits for dioxins are now being considered in the United States and in Europe (Seeker 1994). These two factors combine to suggest that there may be formation of dioxins that exceed the proposed emission limits in the baghouse in the dry-wet system. Very small amounts of dioxin precursors are considered sufficient for this dioxin formation to occur (Seeker et al. 1994, Helble and Hlustick 1994).

At present, there is no known data from mixed waste treatment systems to support this dioxin formation concern. However, wet particulate scrubbing is far less susceptible to dioxin formation because the offgas is more rapidly quenched to a much lower temperature, typically $130-180^{\circ} \mathrm{F}$. There are plans to perform pilot-scale testing of mixed waste vitrification using nonradioactive surrogates at the U.S. Bureau of Mines, Albany Research Center, in Albany, Oregon, in 1995 (Soelberg 1994). The test system includes an electric arc melter for melting surrogate wastes and a dry-wet offgas system from which the system evaluated in the AdvMWTP meeting was modelled. Inclusion of dioxin tests in the planned tests will provide data to help resolve this concern.

There are several reasons why dioxin emissions from a mixed waste treatment process equipped with a dry-wet system will likely be low and meet the new proposed limits. Even with the potential for dioxin formation in the baghouse, the highly efficient afterburner (designed and operated to meet both RCRA and TSCA requirements) will theoretically reduce the amounts of organic precursors, which will reduce dioxin formation in the baghouse. This reduction may not be sufficient to meet the new regulations, but the baghouse itself will remove much of the dioxins that are formed because dioxins are typically associated with the particulate. The downstream charcoal filters and HEPA filters will even more effectively control small amounts of dioxins 
formed in the offgas system. The maximum temperature of $120^{\circ} \mathrm{F}$ for the charcoal absorbers enables the charcoal to readily absorb mercury and organics, including dioxins in the gas phase. At such low temperatures, most of any remaining dioxins may be absorbed onto fine particles, which will be efficiently filtered in the HEPA filters.

\subsubsection{Wet-Dry Offgas System}

Because of the dispersible baghouse fines and the dioxin formation concerns relative to drywet offgas systems, the subcommittee recommended that a wet-dry offgas control system also be considered. The major components of this system would include

- An afterburner, fossil-fuel fired

- Almost total quench using water spray, with air atomization for the water

- A free-jet scrubber system

- A mist eliminator

- A reheater for raising gas above dew point (electric resistance heating)

- Recycle for maintaining a relatively constant offgas flowrate, melter temperature quench, kiln seals pressurization, etc.

- A coarse prefilter

- Carbon filters for $\mathrm{Hg}$, VOCs, and semi-VOCs

- HEPA filters for final filtration

- An ID fan with controlling damper

- Ventilation to the atmosphere.

This type of offgas system has been used successfully in the pilot-scale plasma centrifugal reactor operated by Mountain States Energy in Butte, Montana, and in the Defense Waste Processing Facility and the Consolidated Incineration Facility at the Savannah River Site.

\subsubsection{Comparison of Dry-Wet and Wet-Dry Offgas Systems}

A qualitative comparison of the technical features showing the advantages and disadvantages of the dry-wet and wet-dry offgas systems is presented in Table 8-1. The primary physical differences are in the order and mechanisms of particulate and acid gas control. The up-front thermal oxidation and the downstream reheating, charcoal filtration, and HEPA filtration steps can be identical. In the dry-wet system, the particulates (and most toxic metals and radionuclides) 
Table 8-1. Comparison of dry-wet and wet-dry offgas systems.

\begin{tabular}{|c|c|c|c|c|c|c|c|c|}
\hline \multirow{2}{*}{$\begin{array}{c}\text { Offgas } \\
\text { System Unit } \\
\text { Operation }\end{array}$} & \multicolumn{4}{|c|}{ Dry-wet Offgas System } & \multicolumn{4}{|c|}{ Wet-dry Offgas System } \\
\hline & $\begin{array}{l}\text { Primary } \\
\text { equipment }\end{array}$ & Features & Advantages & Disadvantages & Equipment & Features & Advantages & Disadvantages \\
\hline $\begin{array}{l}\text { Complete } \\
\text { oxidation of } \\
\text { organics }\end{array}$ & $\begin{array}{l}\text { Thermal } \\
\text { oxidizer }\end{array}$ & $\begin{array}{l}\text { fossil-fuel fired, } \\
99.9999 \% \mathrm{DE}, \\
1,200 \mathrm{C}\end{array}$ & $\begin{array}{l}\text { Meets } R C R A \text { and } \\
\text { TSCA requirements }\end{array}$ & $\begin{array}{l}\text { Slagging/fouling } \\
\text { potential, thermal } \\
\mathrm{NO}_{\mathrm{x}} \text { formation }\end{array}$ & $\begin{array}{l}\text { Same as for } \\
\text { dry-wet } \\
\text { system }\end{array}$ & - & - & - \\
\hline $\begin{array}{l}\text { Offgas } \\
\text { cooling }\end{array}$ & $\begin{array}{l}\text { Partial } \\
\text { quench } \\
\text { using spray } \\
\text { cooler and } \\
\text { gas dilution }\end{array}$ & $\begin{array}{l}\text { Cool to } 300 \mathrm{~F} \text { for } \\
\text { baghouse filtration }\end{array}$ & $\begin{array}{l}\text { Reliable, maintenance- } \\
\text { free operation, } \\
\text { prevents corrosion, } \\
\text { filter blinding and } \\
\text { damage in baghouse }\end{array}$ & $\begin{array}{l}\text { offgas flow rate } \\
\text { increase by }-2.5 x \text {, } \\
\text { not cool enough for } \\
\text { dioxin prevention }\end{array}$ & $\begin{array}{l}\text { Total or } \\
\text { almost } \\
\text { quench } \\
\text { using water } \\
\text { spray }\end{array}$ & $\begin{array}{l}\text { Cool to } 200 \mathrm{~F} \text { or } \\
\text { less }\end{array}$ & $\begin{array}{l}\text { Reliable, lower } \\
\text { temperature reduces } \\
\text { dioxin formation, } \\
\text { offgas flow rate } \\
\text { increase by } \sim 2 x\end{array}$ & $\begin{array}{l}\text { Potential for fouling } \\
\text { and corrosion over } \\
\text { wide temperature } \\
\text { change, results in } \\
\text { aqueous, mixed waste } \\
\text { secondary stream, fails } \\
\text { to meet secondary } \\
\text { stream objectives as } \\
\text { defined }\end{array}$ \\
\hline $\begin{array}{l}\text { Particulate } \\
\text { control }\end{array}$ & $\begin{array}{l}\text { Pulse-jet } \\
\text { baghouse }\end{array}$ & $\begin{array}{l}\text { Efficient } \\
\text { particulate } \\
\text { filtration, } \\
\text { produces easy to } \\
\text { recycle or treat } \\
\text { dry, mixed waste } \\
\text { secondary stream }\end{array}$ & $\begin{array}{l}\text { Reliable, state-of-art } \\
\text { filtration, meets } \\
\text { secondary stream } \\
\text { objectives by } \\
\text { separating almost all } \\
\text { of the particulate and } \\
\text { radionuclides from the } \\
\text { aqueous scrubber } \\
\text { solution produced } \\
\text { during acid gas } \\
\text { scrubbing }\end{array}$ & $\begin{array}{l}\text { Presence of } \\
\text { dispersible alpha fines, } \\
\text { worker exposure and } \\
\text { contamination hazard } \\
\text { during maintenance, } \\
\text { potential for dioxin } \\
\text { formation }\end{array}$ & $\begin{array}{l}\text { Particulate } \\
\text { and acid gas } \\
\text { control by } \\
\text { free-jet } \\
\text { scrubber } \\
\text { with mist } \\
\text { eliminator }\end{array}$ & $\begin{array}{l}\text { Tandem nozzle, } \\
\text { steam or air } \\
\text { ejector drive, } \\
\text { efficient scrubber } \\
\text { liquid atomization } \\
\text { and particulate } \\
\text { and acid gas } \\
\text { scrubbing followed } \\
\text { by agglomeration } \\
\text { and mist } \\
\text { elimination }\end{array}$ & $\begin{array}{l}\text { Provides combined } \\
\text { particulate and acid } \\
\text { gas scrubbing with } \\
\text { minimal dioxin } \\
\text { formation }\end{array}$ & $\begin{array}{l}\text { Potential for erosion, } \\
\text { fouling and corrosion } \\
\text { of metal parts, } \\
\text { susceptibility to } \\
\text { differential pressure } \\
\text { and flow rate } \\
\text { variations, results in } \\
\text { aqueous, mixed waste } \\
\text { secondary stream, } \\
\text { criticality concerns, } \\
\text { fails to meet } \\
\text { secondary stream } \\
\text { objectives }\end{array}$ \\
\hline $\begin{array}{l}\text { Acid gas } \\
\text { control }\end{array}$ & $\begin{array}{l}\text { Total } \\
\text { quench and } \\
\text { packed bed } \\
\text { scrubber }\end{array}$ & $\begin{array}{l}\text { Efficient acid gas } \\
\text { scrubbing in } \\
\text { counter-flow } \\
\text { scrubber }\end{array}$ & $\begin{array}{l}\text { Reliable, state-of-art } \\
\text { scrubbing, meets } \\
\text { secondary stream } \\
\text { objectives with } \\
\text { majority of particulate } \\
\text { efficiently removed in } \\
\text { baghouse }\end{array}$ & $\begin{array}{l}\text { Aqueous secondary } \\
\text { stream }\end{array}$ & See above & See above & See above & See above \\
\hline
\end{tabular}


Table 8-1. (continued).

\begin{tabular}{|c|c|c|c|c|c|c|c|c|}
\hline \multirow{2}{*}{$\begin{array}{l}\text { Offgas } \\
\text { System Unit } \\
\text { Operation }\end{array}$} & \multicolumn{4}{|c|}{ Dry-wet Offgas System } & \multicolumn{4}{|c|}{ Wet-dry Offgas System } \\
\hline & $\begin{array}{l}\text { Primary } \\
\text { equipment }\end{array}$ & Features & Advantages & Disadvantages & Equipment & Features & Advantages & Disadvantages \\
\hline Reheat & $\begin{array}{l}\text { Electric } \\
\text { reheater }\end{array}$ & $\begin{array}{l}\text { Raise gas } \\
\text { temperature above } \\
\text { dew point by } \\
\text { around } 10 \mathrm{~F} \text { to } \\
\text { prevent } \\
\text { downstream } \\
\text { moisture } \\
\text { condensation }\end{array}$ & $\begin{array}{l}\text { Electric reheat does } \\
\text { not increase gas flow } \\
\text { rate }\end{array}$ & $\begin{array}{l}\text { Less energy efficient } \\
\text { than fossil-fired reheat }\end{array}$ & $\begin{array}{l}\text { Same as for } \\
\text { dry-wet } \\
\text { system }\end{array}$ & - & - & - \\
\hline $\begin{array}{l}\text { Particulate } \\
\text { prefiltration }\end{array}$ & $\begin{array}{l}\text { Coarse } \\
\text { HEPA } \\
\text { filters }\end{array}$ & $\begin{array}{l}\text { Protect the carbon } \\
\text { filters and HEPA } \\
\text { filters from } \\
\text { relatively larger } \\
\text { particulate }\end{array}$ & $\begin{array}{l}\text { Prevents particulate } \\
\text { plugging of carbon } \\
\text { filters and extends life } \\
\text { of HEPA filters }\end{array}$ & $\begin{array}{l}\text { Results in a secondary } \\
\text { waste stream }\end{array}$ & $\begin{array}{l}\text { Coarse } \\
\text { HEPA } \\
\text { filters }\end{array}$ & $\begin{array}{l}\text { Filter out } \\
\text { particulate, } \\
\text { especially } \\
\text { hydrophobic dusts, } \\
\text { not collected in } \\
\text { the free-jet } \\
\text { scrubber }\end{array}$ & $\begin{array}{l}\text { Prevents particulate } \\
\text { plugging of carbon } \\
\text { filters and extends life } \\
\text { of HEPA filters }\end{array}$ & $\begin{array}{l}\text { Results in a secondary } \\
\text { waste stream }\end{array}$ \\
\hline $\begin{array}{l}\text { Trace } \\
\text { organics and } \\
\mathrm{Hg} \text { control }\end{array}$ & $\begin{array}{l}\text { Carbon bed } \\
\text { filter }\end{array}$ & $\begin{array}{l}\text { Operate at } \\
\text { temperature } \\
\text { maximum of } 120 \\
\text { F for optimum } \\
\text { absorption } \\
\text { efficiency }\end{array}$ & $\begin{array}{l}\text { Efficient for absorbing } \\
\text { trace-level organics } \\
\text { and } \mathrm{Hg}\end{array}$ & $\begin{array}{l}\text { Results in a secondary } \\
\text { waste stream }\end{array}$ & $\begin{array}{l}\text { Same as for } \\
\text { dry-wet } \\
\text { system }\end{array}$ & - & - & - \\
\hline $\begin{array}{l}\text { Final } \\
\text { particulate } \\
\text { filtration }\end{array}$ & HEPA filter & $\begin{array}{l}>99.98 \% \text { efficient } \\
\text { at } 0.3 \text { micron }\end{array}$ & $\begin{array}{l}\text { Necessary for } \\
\text { radioactive waste } \\
\text { processes }\end{array}$ & $\begin{array}{l}\text { Results in a secondary } \\
\text { waste stream }\end{array}$ & $\begin{array}{l}\text { Same as for } \\
\text { dry-wet } \\
\text { system }\end{array}$ & - & - & - \\
\hline
\end{tabular}


are removed from the offgas in a baghouse, and the acid gases are removed in a packed-bed scrubber downstream of the baghouse. In the wet-dry system, the particulates (including most toxic metals and radionuclides) are removed in the free-jet scrubber step.

Because of the differences in particulate and acid gas control, each of the systems has distinct advantages and disadvantages. These are summarized as follows:

\section{Offgas}

system Advantages

Dry-wet Separate particulate-radionuclidehazardous metal secondary stream that is treatable or recyclable.

Wet scrubber criticality is not a concern because, essentially, all radionuclides are removed in the baghouse.

Wet-dry No dispersible fines, unless treatment of the scrubber residue requires precipitation, filtration or drying

Prevents significant dioxin formation by rapidly quenching the offgas to under $200^{\circ} \mathrm{F}$.

Marginally better $\mathrm{Hg}$ control upstream of the charcoal filters due to the initial quench to a lower gas temperature.

\subsubsection{Miscellaneous Comments}

The offgas subcommittee had a number of miscellaneous comments, questions, or concerns:

- The selection of the glass/ceramic waste form versus other waste forms such as portland cement or macroencapsulation was appropriately conservative, considering the uncertainties in the location and acceptance criteria for potential disposal sites.

- More definitive, specific functional, and operational requirements for the entire treatment system are needed to better differentiate between apparently mutually exclusive goals for the offgas system.

- There was some discussion of the potential for remote maintenance and remote operations for the treatment facility. It was thought that remote operations using master-slave manipulators during routine process operation was possible if necessary. 
The potential for remote maintenance in all maintenance situations is less easily done. There should be the expectation and capability within the system to perform at least some contact maintenance.

- Alpha fines control, criticality, and other safety issues should be evaluated in a Safety Analysis Report to enable better determination of whether a dry-wet or wet-dry offgas system is more appropriate

- In the scenario that includes thermal desorption or incineration prior to the melter step, the decision of separate or combined offgas systems should be decided from considering primarily the mutual affects that the desorber/incinerator and the melter have on each other if they share a single offgas system. It is likely that the potential for deleterious back-pressure effects on one unit from pressure, temperature, or flow variations in the other unit will make separate offgas systems preferable. Other factors to consider include relative differences in offgas flowrates and compositions.

- If initial oxidation of fixed carbon or thermal desorption of volatile materiais is necessary prior to melting, rotary kiln technology is the obvious choice for this step. Rather than operating the kiln in a substoichiometric or near stoichiometric mode as proposed, the kiln should be operated in an oxidizing mode to provide better oxidation of fixed carbon. The proposed operating temperature should be reduced from 1800 to $1600^{\circ} \mathrm{F}$ to reduce the potential for slagging some materials in the kiln.

- The offgas system, regardless of equipment selected, typically cannot tolerate the offgas flowrate extremes that would result from processing the waste extremes at the same waste feed rate. Options available to control the offgas flowrate extremes include (a) control the waste feed rate, regardless of waste type, so that the offgas flowrate remains relatively constant, (b) use exhaust gas recycle or added dilution air to maintain a nominally constant total flowrate, or (c) control the melter feed rate and the auxiliary fuel input to the afterburner so that there is a relatively constant heat input to the afterburner.

- The proposed excess oxygen level of $10 \%$ (total oxygen stoichiometry of $110 \%$ ) in the afterburner is not sufficient to ensure efficient thermal destruction and oxidation of organics. The actual excess oxygen level should be determined based on operation with the proposed oxygen-fired system, but excess oxygen levels of $100 \%$ are common for conventional air-fired afterburners.

- Detailed energy and mass balances should be conducted when comparing different system alternatives and for design of the selected system size and features. For example, using oxygen instead of air for combustion throughout the system, while reducing the overall offgas flowrate, will significantly increase gas temperatures in the afterburner, the melter and the thermal desorber (if used) for some waste feeds. This may result in the need to include cooler, inert, recirculated offgas, air, or an inert gas such as carbon dioxide for temperature control. 
- Design and operation of the demister for either the dry-wet or wet-dry offgas systems is very important for eliminating water droplets (and salts dissolved in the water droplets). Even with the reheater, any remaining water droplets may not be vaporized and will cause undesirable moisture in the HEPA filters. Dissolved salts in water droplets not removed from the offgas will undesirably increase the particulate loadings in the charcoal filters and HEPAs.

- One of the advantages of the dry-wet offgas system is the ability to remove particulate, including radionuclides and toxic metals upstream of the wet scrubbing step to reduce the amounts, toxicity, and radioactivity of the wet scrubber residues. However, it is not likely that the scrubber residues will be determined nonradioactive. HEPA filters placed downstream of the baghouse but upstream of the wet scrubber would efficiently remove any particulate not collected in the baghouse, but would be prone to corrosion, plugging, and other problems because the offgas at that location has not yet undergone acid gas removal.

- The wet-dry system should be seriously considered as an alternative to the dry-wet system, due primarily to the dioxin formation concern and the concern with worker exposure and contamination control during baghouse maintenance. The final decision depends on more detail and requirements of the Safety Analysis Report and Functional and Operational Requirements.

- Metals volatilization and control in the offgas system remains a concern

- Methods of hot filtration such as using ceramic candle filters or metal filters are not established by widespread use. Their performance to filter the offgas from these types of wastes under these conditions is not proven and is susceptible to offgas and particulate properties. Metal filters are not suitable for operation at the afterburner outlet temperature of up to $2400^{\circ} \mathrm{F}$. Therefore, it is justifiable to exclude hot filtration from the current evaluation.

\subsubsection{Conclusions}

Several conclusions regarding the offgas system were obtained from the presentations and discussions. The review of the entire system, including the offgas system, was considered very timely at this stage in the AdvMWTP development because of the importance of getting stakeholders involved early in the process. Stakeholders include the public, local and state governments, and regulatory agencies. Support will be needed from such government groups as the Western Governors' Association DOIT Committee. Regulatory permit writers need to be involved early to educate the AdvMWTP working team of their constraints relative to technologies and permitting. The AdvMWTP team needs to also educate the permit writers about the system and designs, and identify potential gaps in information or data that will be required to do facility design and obtain permits. 
Conclusions regarding the proposed dry-wet offgas system include the following:

- The proposed system can best meet the specified design and operating objectives of reliable operation, efficient control of pollutant emissions within regulatory limits, ability to tolerate offgas flowrate and composition variations, and meet secondary stream objectives to maximize recycle, minimize volumes and masses, and avoid mixed waste scrubber solutions.

- Two potential concerns with this system are (a) the existence of fine, easily dispersed particulate matter that will contain chlorides, toxic metals, and, potentially, alphacontaminated particles, that will be a contamination hazard during baghouse maintenance and handling of this secondary stream, and (b) the potential for dioxin formation at the relatively low temperatures of baghouse filtration.

- More specific functional and operating requirements will help to determine if the presence of fines in the baghouse is a significant issue. These requirements should include secondary stream and baghouse operating and maintenance requirements.

- There is insufficient dioxin emission data at this time to confirm if dioxins would be generated in amounts exceeding the expected dioxin emission limits. Even if there is some dioxin generated in the baghouse, very effective control of the dioxins should be achieved in the downstream charcoal filter and HEPA filter. Dioxin formation is less of an issue for this type of system than in the common industrial and incinerator offgas systems that do not include the downstream charcoal and HEPA filtration.

The alternative to dry filtration for particulate control is wet particulate scrubbing, which results in an aqueous secondary stream containing dissolved and suspended particulate matter, sludge, chlorides, toxic metals, radionuclides, and chlorides. Conclusions regarding the wet-dry system include the following:

- The wet secondary stream will consist of an aqueous solution containing dissolved acid gases (primarily chlorides and sulfates), suspended and dissolved particulate matter, toxic metals, and radionuclides. This secondary stream eliminates the potential for dispersible fines unless secondary treatment requires precipitation, filtration or drying. Recycling the secondary stream or stabilization options that include essentially any technology besides Portland cement solidification will likely require filtration, precipitation, or evaporation.

- The rapid temperature quench and low operating temperature prevents significant dioxin formation.

- There is marginally better $\mathrm{Hg}$ control upstream of the charcoal filters due to the initial quench to a lower gas temperature.

- A safety analysis is required to evaluate the concerns for potential criticality in the scrubber solution. 


\subsubsection{Recommendations}

A number of recommendations were developed based on the results and conclusions:

- More definitive, specific functional and operational requirements for the entire treatment system are needed to better differentiate between apparently mutually exclusive goals for the offgas system. Alpha fines control, criticality and other safety issues should be evaluated in a Safety Analysis Report (SAR) to enable better determination of whether a dry-wet or wet-dry offgas system is more appropriate.

- The wet-dry system should be seriously considered as an alternative to the dry-wet system, due primarily to the dioxin formation concern and the concern with worker exposure and contamination control during baghouse maintenance. The final decision depends on more detail and requirements of the Safety Analysis Report and Functional and Operational Requirements.

- Detailed energy and mass balances should be conducted when comparing different system alternatives and for design of the selected system size and features.

- The offgas system, regardless of equipment selected, cannot typically tolerate the offgas flowrate extremes that would result from processing the waste extremes at the same waste feed rate. The best options for controlling the offgas flowrate extremes (a) use exhaust gas recycle or added dilution air to maintain a nominally constant total flowrate, and (b) control the melter feed rate and the auxiliary fuel input to the afterburner so that there is a relatively constant heat input to the afterburner.

- The question of including thermal desorption or incineration prior to the melter step should be resolved based on the ability of the selected melter to tolerate all potential feed mixture variations and operating conditions. If initial oxidation of fixed carbon or thermal desorption of volatile materials is necessary prior to melting, then rotary kiln technology is the obvious choice for this step. Rather than operating the kiln in a substoichiometric or near stoichiometric mode as proposed, the kiln should be operated in an oxidizing mode to provide better oxidation of fixed carbon. The proposed operating temperature should be reduced from $1800^{\circ} \mathrm{F}$ to $1600^{\circ} \mathrm{F}$ to reduce the potential for slagging some materials in the kiln.

- The question of separate or combined offgas systems for the desorber/incinerator and the melter should be decided from considering the mutual affects that the desorber/incinerator and the melter have on each other if they share a single offgas system. It is likely that the potential for deleterious back-pressure effects on one unit from pressure, temperature, or flow variations in the other unit will make separate offgas systems more preferable than combined offgas systems. Other factors to consider include relative differences in offgas flowrates and compositions.

- While remote operations using master-slave manipulators during routine process operation is possible if necessary, remote maintenance in all maintenance situations is not as easy. Expect to perform at least some contact maintenance. 


\subsection{Overall System Design}

The system subcommittee was charged to look at issues concerning a melter-based thermal treatment system from a broad perspective, which was to umbrella issues brought up in the melter and offgas technical sessions. The system subcommittee focused on issues relating to

- Integration of a melter system into a facility capable of waste acceptance and characterization, melter feed preparation and thermal destruction, secondary waste treatment, and process residue handling

- System operability, maintainability, and emissions control technologies.

Highlights of the system subcommittee's comments are summarized as follows in Sections 8.4.1 through 8.4.10. Appendix A includes the full committee report.

\subsubsection{Stakeholder Involvement}

The translation and interpretation of criteria for the issuance of an operating permit by regulatory personnel may influence the design or the selection of technology or equipment. A key issue is the satisfaction of the regulatory requirements for characterization.

\subsubsection{Impact of the System Front End on Selection of a Melter}

- Alpha radiation assay.

It is highly likely that the waste will have to be removed from the containers for assay of alpha (fissile) activity. Assumptions that full drums can be fed directly to a thermal treatment unit are probably not valid.

- Characterization of input waste for RCRA permit compliance.

It is highly likely that the RCRA permit will require characterization of the input waste to identify BTU value, metals, and key organic compounds (e.g., halogens).

- Sorting requirements.

No matter how robust the melter design is, some amount of sorting will be needed.

- Safety Analysis Reviews.

Safety reviews may impose further limitations on characterization, sorting, or the TRU or gamma content of the waste input. These types of reviews must proceed with the total design. 


\subsubsection{Single-Step Thermal Treatment Unit}

A two-step thermal processing system should be avoided if a single-step system, which combines organic destruction and stabilization, can be proven effective as recommended by the melter subcommittee.

Additional Incinerator Design Issues. According to the offgas subcommittee, there was no compelling reason to include the incinerator in the system with the melter. If the melter can accept waste containing large amounts of organic and inorganic volatiles, then the incinerator should be deleted from the design for simplicity and reduced cost. However, the subcommittee cautions that acceptable melter performance for high-organic-content wastes needs to be verified and may prove problematic. The subcommittee recommends that provision for an incinerator be included, its benefit being that it will reduce the composition variability of the feed to the melter, thereby allowing for more stable and controllable melter operation. If the incinerator is judged to be necessary due to the inability of the melter to tolerate volatiles and organics or widely varying waste composition, then the following issues apply:

Selection of rotary kiln-The complex and unknown nature of the waste to be processed is a central issue in the selection of a rotary kiln. The proposed selection appears to be appropriate, with the caveat that common kiln seals are not adequate for this application for contamination control or for control of inleakage.

Oxidative versus pyrolytic operations-These options were not considered at length because of the potential for excluding the incinerator from the system. A significant issue is the ability for the melter to accept and to process fixed carbon from the waste. An oxidative kiln will reduce fixed carbon to much lower levels than a pyrolytic one. Steam injection was proposed as an alternate method to reduce fixed carbon content of the pyrolyzed waste, though this method was not uniformly endorsed by the entire subcommittee. There was no agreement by the melter subcommittee as to the acceptability of fixed carbon in the melter feed material.

Potential slagging with high alkali metal wastes-Some of the wastes, and even the soil, contain alkali metals, including sodium and potassium, that typically have lower melting points and can attack the kiln refractory. The selection of an $1800^{\circ} \mathrm{F}$ operating temperature for the kiln should be reconsidered. Most subcommittee members felt that a $1600^{\circ} \mathrm{F}$ kiln exit gas temperature and a reasonably long residence time for solids in the kiln would be sufficient for effective organic constituent and fixed carbon burnout, while avoiding potential slagging problems. The kiln solids may be at an even lower temperature, since a $300^{\circ} \mathrm{F}$ temperature difference between the gas and solids in a kiln is common. Thus, the choice of lower temperatures with a commensurate increase in residence time could enhance operation.

Incinerator Operation Conclusions. In summary, the offgas subcommittee believes that the need of a incinerator is a melter design issue. A rotary kiln will work, and oxidative operation would result in less fixed carbon in the melter feed. It is also recommended that the operating temperature be reconsidered, that a temperature of $1600^{\circ} \mathrm{F}$ may be more appropriate. 


\subsubsection{Operability and Maintainability Considerations}

System maintainability and operability will have a profound effect on the equipment and process selection and design. The melter and related equipment will probably require triple confinement.

- Operability and Maintainability Strategy

A system-wide operability and maintainability strategy and criteria must be developed. For the initial conceptual level design, the use of remote maintenance for all routine maintenance items is recommended, as well as design for good housekeeping and cleanliness in the process areas.

- Design for Decontamination

All waste handling and processing equipment should be designed for easy decontamination (and decommissioning).

\subsubsection{Material Handling}

- Feed size reduction

All material should be size reduced for better waste characterization and to meet the needs of the melter. A nominal four (4) inch feed size is recommended by the melter subcommittee.

- Controlled feed blending

The system design should enable a certain level of mixing and blending for uniformity and consistency of the feed if required.

- Design for ease of maintenance

The basaltic soil base and the IEB composition are extremely abrasive; moving parts and rotating machinery with seals should be minimized.

\subsubsection{System back-end considerations}

- Final waste form characterization

The Environmental Protection Agency requires sampling of the final product for toxicity characterization leaching. Sampling of the cooled product by core drilling may not be applicable, sampling of the molten product should be investigated.

- Radiological considerations 
Assay of the containerized package may be sufficient for gamma; however, it may be insufficient for alpha-emitting radionuclides or for compliance to the QA requirements according to the WIPP WAC.

\subsubsection{Demonstration Program Strategy}

The ultimate use of the demonstration should be identified. A facility designed for cold tests only will not be suitable for hot tests later; a facility capable of performing hot tests may be too expensive and encumbered to enable cold test to be performed efficiently.

\subsubsection{Input Waste Acceptance Criteria}

System input waste acceptance criteria should be identified to establish limits of acceptance for key constituents, such as HVPMs, PCBs, PVC, dioxins, radioactive gamma emitters, and fissile content (TRU concentration).

\subsubsection{Final Waste Form Criteria}

Criteria for the quality and acceptance of the products produced, i.e., primary, secondary, and other waste forms must be established early to enable coordination with future DOE disposition decisions.

\subsubsection{On-line Continuous Emissions Monitors}

The success of the thermal treatment system will depend on acceptance by the stakeholders. Of key concerns are the releases of gases to the environment. Inclusion of state-of-the-art monitoring instrumentation should be a top priority in the total design.

\subsection{Recommendations}

Specific recommendations are found in Sections 8.1 through 8.4.

This engineering system design study defined the constraints, identified available options, compared and evaluated the various options, and obtained detailed impartial technical review from technical experts in the required disciplines. It is recommended that this systems evaluation and technical peer review approach be used to obtain consensus and determine optimum treatment scenarios and programs.

This approach will ensure that treatment scenarios and programs will be engineered based on sound technical application rather than on administrative, political, or other issues. It will also initiate support from stakeholders for the optimal technical solutions. 


\section{REFERENCES}

Arrenholz, D. A and J. L. Knight, 1990. A Brief Analysis and Description of Transuranic Waste Disposal in the Subsurface Area of the Radioactive Waste Management Complex at the INEL, WTD-90-016, EG\&G Idaho, Inc., Idaho Falls.

Bickford, D. F., 1993. "Waste Vitrification Programs at Savannah River Site," Paper 27, Emerging Technologies in Hazardous Waste Management $V$, Atlanta Georgia, September 27-29, American Chemical Society.

Bosley, J., ed.,1992. Proceedings of the 1992 CMP Electric Arc Furnace Dust Treatment Symposium, CMP Report 92-4, EPRI Center for Materials Production, Electric Power Research Institute, Palo Alto, June.

Clements, T. L., Jr., 1982. Content Code Assessments for INEL Contact-Handled Stored Transuranic Wastes, WM-F1-82-021, EG\&G Idaho, Inc., EG\&G Idaho, Inc., October.

DOE Office of Environmental Management 1994. Mixed Waste Integrated Program, Technology Summary, DOE/EM-125P, U.S. Department of Energy, Office of Technology Development, February.

Eckert, E. R. G, 1973. "Part A: Relations and Properties, Section 15: Radiation," W. M. Rohsenow and J. P. Hartnett (eds.), Handbook of Heat Transfer, McGraw Hill, New York, pp. 15-40.

Eddy, T. L., et al., 1992. Thermal Processing System Concepts and Considerations for RWMC Buried Waste, EGG-WTD-10058, EG\&G Idaho, Idaho Falls, Idaho, February.

Eddy, T. L., and B. D. Raivo 1995. Arc Melter Configurations: Preliminary Design Considerations, INEL-95-0058, EG\&G Idaho, Inc., Idaho Falls, Idaho, February.

Dalton, J. D., W. P. Wolfe, and R. M. Geimer, 1994, Air Pollution Control System Flowsheet for the Pilot-Scale PHP System, SAIC-94/1042, February.

Feizollahi, F., et al. 1994, "Integrated Thermal Treatment System Study-Phase 1 Results," EGG-MS-11211, EG\&G Idaho, Inc., Idaho Falls, Idaho, July 1994.

Flinn, J. E., et. al., 1981. Annual Report on the TRU Waste Form Studies with Special Reference to Iron-Enriched Basalt: 1980, EGG-FM-5366, EG\&G Idaho, Inc., Idaho Falls, Idaho, June.

Flinn, J. E., et al., 1981. Iron-Enriched Basalt Peer Review, EG\&G Idaho, Inc., Idaho Falls, Idaho, August, unpublished review.

Francois, D., 1994. "Installation de traitment de gaz issus d'un four d'incineration de dechets amiantiferes: INERTAM," METATECHNIES '94, Bordeaux, France, Sept 12-14. 
Gardner, W., E. I. Cooke, and R. W. I. Cooke 1978. Handbook of Chemical Synonyms and Trade Names, 8th ed., CRC Press.

Gordon, M., (Oregon Steel Mills) 1994. Private communication, Portland Oregon.

Grandy, J. D., T. L. Eddy, G. L. Anderson 1993. TSA Waste Stream and Final Waste Form Composition, EGG-WTD-10617, EG\&G Idaho, Inc., Idaho Falls, Idaho, January.

Grandy, J. D., T. L. Eddy, and G. L. Anderson 1993. Property and Process Correlations for Iron-Enriched Basalt Waste Forms, EGG-MS-10657, EG\&G Idaho, Idaho Falls, Idaho, February.

Helble, J. and D. Hlustick 1994. "Dioxin Emissions and Congener Distributions Resulting from Hazardous Waste Incineration," Air and Waste Management Association Conference, Cincinnati, Ohio.

Kong, P. C. 1991. Interoffice Correspondence, PCK-10-91, Criteria and Requirements for Final Waste Form, Letter Report, Task 3.0, EG\&G Idaho, Inc., Idaho Falls, Idaho, September 12.

Kong, P. C., et al., in preparation. Final Waste Form Option Scoping Studies for RWMC Wastes, EGG-WTD-10363, EG\&G Idaho, Inc., Idaho Falls, Idaho.

Kong, P. C., 1991. "Criteria and Requirements for Final Waste Form," Letter Report - Task 3.0 Criteria and Requirements for Final Waste Form - PCK-10-91, EG\&G Interoffice Correspondence, September 12.

Mohiuddin, J., and G. Schneider, Informal noon discussion organized by Buried Waste Integrated Demonstration Peer Review Meeting, February 25, 1994.

Oden, L. L., and W. K O'Connor 1994. ASME/USBM Investigative Program Report on Vitrification of Residue (ASH) from Municipal Waste Combustion Systems, ASME CRTD-Vol 24, American Society of Mechanical Engineers, New York, June.

Pitts, D. (Focus Environmental) 1994. Private communication with the Technical Advisory Committee, October 24.

Reimann, G. A., et al., 1992. Summary of INEL Research on the Iron-Enriched Basalt Waste Form, EGG-WTD-10056, EG\&G Idaho, Inc., Idaho Falls, Idaho, January.

Reimann, G. A., and P. C. Kong 1993. Improving Iron-Enriched Basalt with Additions of ZrO2 and TiO2, EGG-MS-10642, EG\&G Idaho, Inc., Idaho Falls, Idaho, June.

Roesener, W. S. and N. R. Soelberg 1992. Identification of a Waste Treatment Process for the Idaho Waste Processing Facility - A Preconceptual Design Study, WM-PD-92-009, EG\&G Idaho, Inc., Idaho Falls, Idaho, September. 
Sciarrotta, T. (Southern California Edison) and G. L. Anderson (Lockheed Idaho Technologies Company) 1994. Private communication, Rosemead, California and Idaho Falls, Idaho.

Seeker, W. R., (Energy and Environmental Research Corporation) 1994. Private communication with the Technical Advisory Committee, October 24.

Seeker, W. R., et al. 1994. "Combustion Byproducts from Mixed Waste Thermal Treatment Processes: Formation and Control," Energy and Environmental Research Corporation.

Soelberg, N. R., et al. 1994a. Test Plan for BWID Phase 2 Electric Arc Melter Vitrification Tests, INEL-94/0004, Lockheed Idaho Technologies Company., Idaho Falls, Idaho, October.

Soelberg, N. R., et al. 1994b. Arc Melter Demonstration Baseline Test Results, EGG-WTD-11138, July.

Springer, M. D., and W. C. Burns 1993. "Medical Waste Treatment with Plasma Technology," Proceedings of the Second International Plasma Symposium, D. R. MacRae, ed., CMP Report 93-4, EPRI Center for Materials Production, Pittsburgh Pennsylvania, Electric Power Research Institute, Palo Alto, pp. 20-1 to 20-8.

Vigil, M. J., 1990. Subsurface Disposal Area (SDA) Waste Identification (1952-1970 Emphasis), EGG-WM-8727, EG\&G Idaho, Inc., Idaho Falls, Idaho.

Watkins, J. L. , et al. 1993. Test Plan: FY93 Mark II DC Arc Fumace Tests, Pacific Northwest Laboratory, Richland Washington, October 1993.

Whitworth, C. G. , et al. 1992. "Slag Chemistry and Metals Volatilization in the Plasma Arc Furnace Experiment," Spectrum '92, 2, pp.1596-1600, American Nuclear Society, La Grange Park, Illinois. 


\section{Appendix A}

\section{Integrated Melter System Subcommittee Report}


ENVIRONMENTAL SERVICES DIVISION

180 HOWARD STREET

SAN FRANCISCO. CALIFORNIA U.S.A. 94105

TELEX: (WUI) 677058. (ITT) 470040. (RCA) 278362, (WUD) 34376

PHONE (415) 442-7600/FAX- (415) 442.7673

January 3, 1995.

Dr. Tom Eddy

Lockheed Idaho Technologies Co.

P.O. Box 1625

Idaho Falls, ID 83415

Subject: $\quad$ Melter Technology Review Workshop - System Committee Review Comments.

Dear Dr. Eddy:

Thank you for inviting Morrison Knudsen to join you in the INEL melter technology review workshop. Enclosed you will find the System Committee comments. These comments have been generated by the committee members that included myself, $\mathrm{Dr}$. John Kolts, Dr. C.C.Lee, and Mr. Ben Teheranian.

The System Committee reviewed issues related to the integration of a melter system into a facility capable of waste acceptance and characterization, melter feed preparation and thermal destruction, secondary waste treatment, and process residue handling. The system committee also reviewed issues related to system operability, maintainability, and emmissions control technologies.

For additional System Committee comments or questions please call me at (415) 4427546 , or Dr. John Kolts at (208) 526-9909. I look forward to other opportunities for working with you in the future.

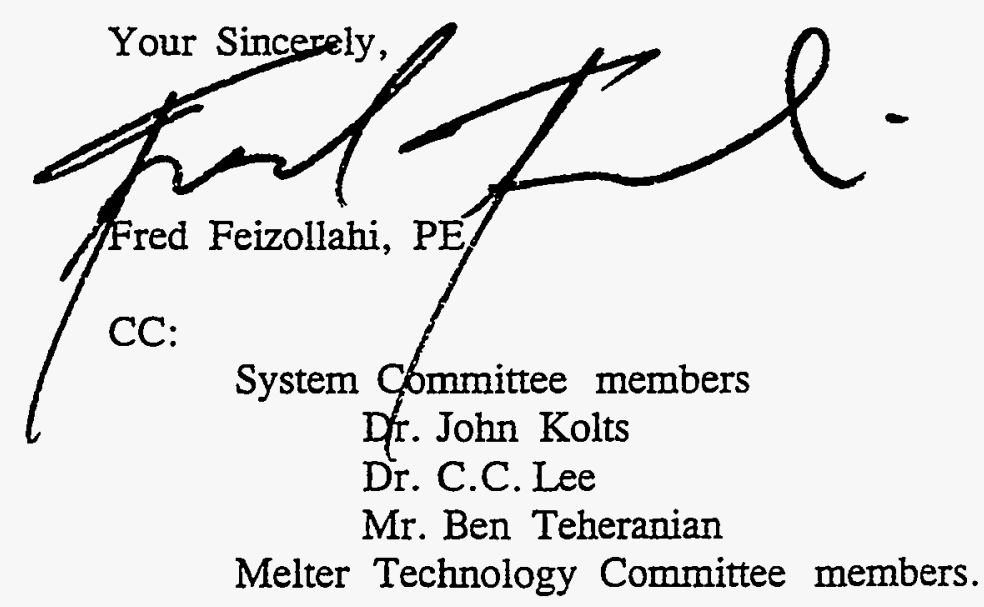




\section{System Committee Review Summary \\ December 23, 1994.}

System committee's comments are as follows:

\section{Stakeholder Involvement}

Early involvement of the stakeholder, especially the regulators, in the project decision making process is highly recommended. The selection of technologies and equipment design may be highly dependent on how the regulators translate the criteria in the operating permit regulation. A key area is the waste characterization requirements. A different interpretation of the regulation could have a significant impact on the hardware design, and capital and operating cost of the overall system.

\section{Impact of System Front-End On Melter Selection}

Alpha radiation assay. It is highly likely that the waste would have to be removed from the containers and placed on top of alpha assay conveyors. Therefore, the assumption that full drums can be fed to a thermal treatment unit is not valid.

Characterization of input waste for RCRA permit compliance. It is highly likely that RCRA permit writers will require characterization of the input waste to identify BTU value, metals, and key organic compounds such as halogens. The characterization requirements need to be further investigated through discussions with the regulator. The robustness of the thermal treatment subsystem may have some impact on the level of characterization requirements, but this must be further investigated. Method and hardware required for characterizing solids will require further investigations and identification of a suitable technique. This technique must be integrated in the overall design of the melter and the feed subsystems.

Sorting requirements. No matter how robust the melter design is, a limited amount of sorting will be needed. For example, graphite, lead gloves, bulk lead, and $\mathrm{Hg}$ contaminated waste may have to be segregated. Hence, sorting capability should be considered for the overall system.

Safety Analysis Reviews. A safety review of the system may show that further limitations on the input waste must be imposed. This may include limitations on the TRU and gamma content of the input waste. Since SAR could result in an additional requirement on the front-end sorting and characterization equipment, 
limited safety analysis should be conducted as early in the project design as possible.

\section{Single Step Thermal Treatment Unit}

The use of two step thermal treatment of the waste should be avoided if possible. A single step thermal treatment unit (i.e., accomplishing organic destruction and stabilization functions in a single process unit operation) appears to have cost and operation advantages.

\section{Operability and Maintainability Considerations}

System maintainability and operability will have a profound effect on the equipment and process selection and design. The melter and other related equipment would have to have a triple confinement feature (similar to a glove box handling).

Operability and maintainability strategy. A system-wide operability and maintainability criteria must be developed. It will be based on compliance with the DOE orders on system design, and health and safety, including ALARA requirements. For the initial conceptual level design, the committee recommends using remote maintenance for all routine maintenance items. The process cells should be designed to be clean at all times during waste handling and processing operations so that limited manual maintenance for non-routine maintenance items can be performed.

Design for decontamination. All waste handling and processing equipment should be designed for ease of decontamination. For example, all surfaces should have a polished finish. Rough surfaces should have covers with smooth surfaces. The use of shrouds to cover appendages, such as valve bodies and operators or electrical connectors, should be considered.

\section{Material Handling}

Feed size reduction. All material should be size reduced (1) for better waste characterization, and (2) to meet the need of the thermal treatment unit. A nominal size of 4 " should be used.

Controlled feed blending. System features should include mixing and blending of the input waste to provide uniformity. This would help maintain a more consistent operation of the melter and offgas units.

Design for ease of maintenance. The use of conveyors, feeders, pumps, and other rotating machinery should be minimized. IEB is extremely abrasive, and seals, bearings and shafts in such equipment will have a very short life. 


\section{System Back End Considerations}

Final waste form characterization. EPA requirements of TCLP may impose routine sampling of the final product. Sampling of the slag by core drilling of the waste in the container may not be a good choice. Pouring molten slag in a small sample container should be investigated. The small sample could be brought to the lab for crushing and for TCLP or other leachability tests.

Radiological characterization. Assay of containerized waste packages may be sufficient for gamma radiation characterization. However, characterization of the waste for alpha assay and compliance with WIPP-WAC may need a different approach. Accordingly, alternative approaches should be studied to determine impact on the melter design. A suitable approach should be used as the basis for design.

\section{Demonstration Program Strategy}

The ultimate use of the demonstration facility should be identified as early as possible. If the facility is to be used only for a series of cold tests, then QA/QC requirements will be to standard industry grade. If this decision is made, the facility will no longer be suitable for hot tests (which require system components that are fabricated and tested with nuclear grade $\mathrm{QA} / \mathrm{QC}$ requirements).

\section{Input Waste Acceptance Criteria}

The exact feed to the system and to the melter (or the thermal treatment unit) should be identified as early in the design as possible. For example, if the system is to handle TRU waste, then the criticality requirements may impose a different set of restrictions on the selection of the equipment and on processes than if the system is to handle only alpha (i.e., $<100 \mathrm{nCi} / \mathrm{g}$ ) waste. Upper or lower limits for other key components of the waste composition, such as the level of HVPM elements, PCBs, dioxin, PVC and other elements, should be established. Similar criteria should also address gamma radiation and nuclide concentrations in the feed. For example, high Cs content in the waste may demand a different set of design requirements on the offgas subsystem.

\section{Final Waste Form Criteria}

It is understood that the main impetus for the demonstration program is alpha waste for which DOE does not have a clear disposal strategy at this time. In any event, it is prudent that a waste form criteria be established early the project, taking into consideration that the system may produce several output waste streams; including solid alpha-MLLW ( such as the melter output), MLLW (such as scrubber salt), LLW ( such as solid and liquid waste produced during house keeping, and process secondary waste), and TRU waste (such waste may be generated as a result of concentrating certain 
organic wastes).

\section{Online Continuous Emission Monitors}

The success of a thermal treatment system at the INEL will depend on the acceptance by the stakeholder. The key concern of the stakeholder is the gases that will be released to the environment. The use of the state-of-the art online CEM technologies being developed by the industry and DOE should be a top priority. These technologies should be included in the system to demonstrate to the stakeholder that an inadvertent release of toxic and hazardous material to the environment can be prevented. 


\section{Appendix B}

\section{Melter Design Subcommittee Report}




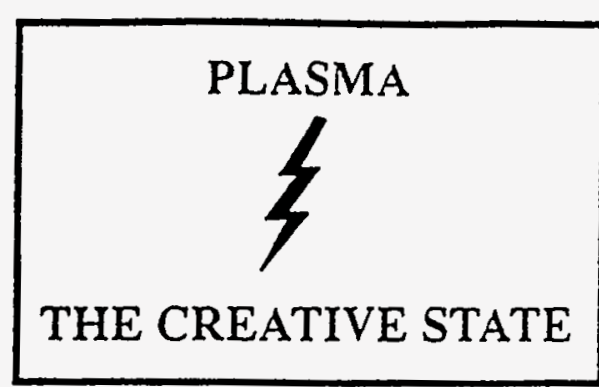

ALAN L. HARE, B.Sc. (Eng.), A.C.G.I.

30 Easson Road

Redcar

Cleveland

TS10 1HJ

ENGLAND

Tel/Fax: $+44(0) 642482681$

22 November 1994

Dr.T.L.Eddy

INEL/LITCO

Idaho Falls

ID. 83415-2210

USA

Dear Tom:

1 enclose 2 copies of the final report of Melter Design Technical Advisory

subcommittee on the INEL IWTP Melter System Design Technical Review Meeting.

We hope this report contributes to the successful development of a viable process.

I hope these are satisfactory.

Yours Sincerely,

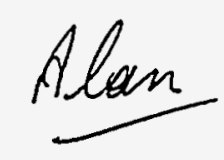

Alan Hare 


\title{
Idaho National Engineering Laboratory \\ Idaho Waste Treatment Program
}

Melter System Preliminary Design

Technical Review Meeting

Idaho Falls, Idaho

October 24-25 1994

Melter Design Technical Advisory Committee

Report

\author{
Members \\ - Alan Hare, Consultant, Chair \\ - Howard Davis, Consultant, Co-Chair \\ - Jerry Feinman, Consultant
}

\section{Introduction}

The report "Arc Melter Configurations: Preliminary Design Consideration, T. L. Eddy, 7-31-94" and the detailed presentations at the meeting provided a comprehensive overview of the options available. The conclusion that several furnace melter designs are capable of meeting the programme objectives was accepted by the committee.

The committee approached the review by considering industrial processes that have features compatible with the proposed melter duty.

\section{Preliminary Discussions}

It was agreed that the 3 phase AC furnace used for rockwool production provides the best model. The process is proven on an industrial scale and is robust both mechanically and operationally. This type of furnace has also been used for many years in EAF steelmaking. The Pyrolyzer should be eliminated because this would simplify the design and operation of the rest of the plant.. 


\section{Conclusions}

\section{Feed Pre-treatment}

The feed should be classified and crushed to ensure that all material is $<4$ ". It is recognised that this is a demanding requirement which poses severe problems in the plant design. It provides the best chance for eliminating the Pyrolyzer, simplifying of the rest of the plant and improving operability.

\section{Furnace Selection}

The basic furnace configuration is sketched in Figure 1. The furnace diameter (DF) should be between 3-5 metres, probably about 4 metres. ( see below for the factors that can influence this dimension ). The power rating should be ca. $2 \mathrm{MW}$ for a feedrate of ca. 2,000 lbs/h. The furnace lining should be a refractory/skull construction with shell cooling, probably by gravity water cooling. With this type of furnace routine maintenance such as electrode replacement and tapping can be done remotely.

The bottom electrode associated with a single electrode $\mathrm{DC}$ arc furnace is believed to be less reliable and require more maintenance than the gas seals on the top entry points for the proposed AC system.

Operation with a cold cap and submerged electrodes ( NO ARC) appears to be the most effective way to minimise unwanted emissions.

The furnace should have 2 metal and 2 slag tapholes. These need regular maintenance and some redundancy is essential for reliable plant operation.

\section{Discussion}

The team believes that the importance of controlling the top size of the feed material and blending to minimise composition variations is difficult to over emphasise. A major concern is the explosive disintegration of larger feed, (such as concrete lumps or other materials with a high volatile content) and its subsequent effect on operation and containment. To handle this problem a larger furnace than necessary based on feedrate considerations is preferred. The justification for this decision is that any disturbance caused by feed quality variations could be absorbed without major upset to furnace operation. This ratio of 4 " feed to a 4 Metre diameter furnace was considered to be a key parameter, if a smaller diameter furnace is used then smaller top size would be recommended.

There was extensive discussion on the need for a Pyrolyzer pre-treatment. It was felt that by using:-

- a large diameter furnace

- a feed arrangement to produce an annular cold cap as shown in the sketch

- control of feed variability as outlined above

the drying and pyrolysis processes would occur in the cold cap as the feed was drawn down into the melt without adversely affecting melter operation. 
This proposal will not impose any additional load on the off gas system, and should simplify its operation. Consequently it was felt that there was no need for a separate Pyrolyzer.

The temperature in the gas space above the cold cap could be adjusted by varying the furnace power to control the dimension DC in Figure 1. This may be desirable to ease the fluctuations in the feed composition to the off-gas treatment plant. This would also affect the cold cap depth and throughput of the system.

\section{NOTE}

1. In the subsequent open forum discussion the constraint posed by "Criticality" was raised; an aspect not considered by the committee. In follow up discussions on this point the members responses covered the following range of options.

Preferred : Feed classification (blending) to ensure it is not a problem Alternatives: Use a smaller furnace with smaller feed material as indicated above. With a smaller furnace it was suggested that the increased power density may make more intensive cooling essential to maintain skull integrity (forced cooling, copper fingers etc.).

If a detailed analysis of the smaller diameter furnace shows this option to be unattractive then this could justify the RETECH (static hearth) type furnace, with a smaller hold-up might be a better option.

2. "Criticality" is only one of a number of regulatory restraints which will dictate the design criteria. The committee did not take these completely into account in their deliberations.

\section{REDOX Potential}

Overall the committee prefers using iron ore to control the oxidation state of the slag. This should be less disruptive to furnace operation than oxygen injection. It was indicated that even with a high oxygen potential in the furnace the graphite electrode consumption would not be excessive. A better definition of the redox potential in the furnace to quantify the effect on process operability and product quality is needed.

\section{Furnace Control}

Recognised as a major problem. The best solution proposed is to tap the slag continuously and monitor its temperature/viscosity. It was suggested that the furnace operator would soon learn how to control. the plant. It was suggested that a target slag viscosity was ca. 4 poise. and values above 10 poise should be avoided. However some doubt was expressed as to whether or not the production rate would be high enough to keep the tap hole free.

\section{Final Thoughts}

A recurrent theme in the feedback from the members during the preparation of this report has been the need for experimental confirmation of the assumptions made in arriving at these recommendations. 


\section{General Comments}

The following comments may be helpful in planning future reviews.

1. The number of committee members should not be less than 4

2. The documentation provided should be comprehensive. (It was in this case)

3. The presentations were essential to provide the right focus.

4. The time allowed for committee work was too short; another half day would have been useful.

5. The documentation should be circulated earlier to allow more preparation time.

6. Some advance personal interaction is useful; but more difficult to arange.

7. The blend of experience to cover all the options should be appropriate.

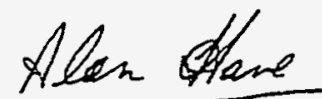

Alan Hare

Howard Davis

Jerry Feinman

11 November 1994

\section{Figure 1}

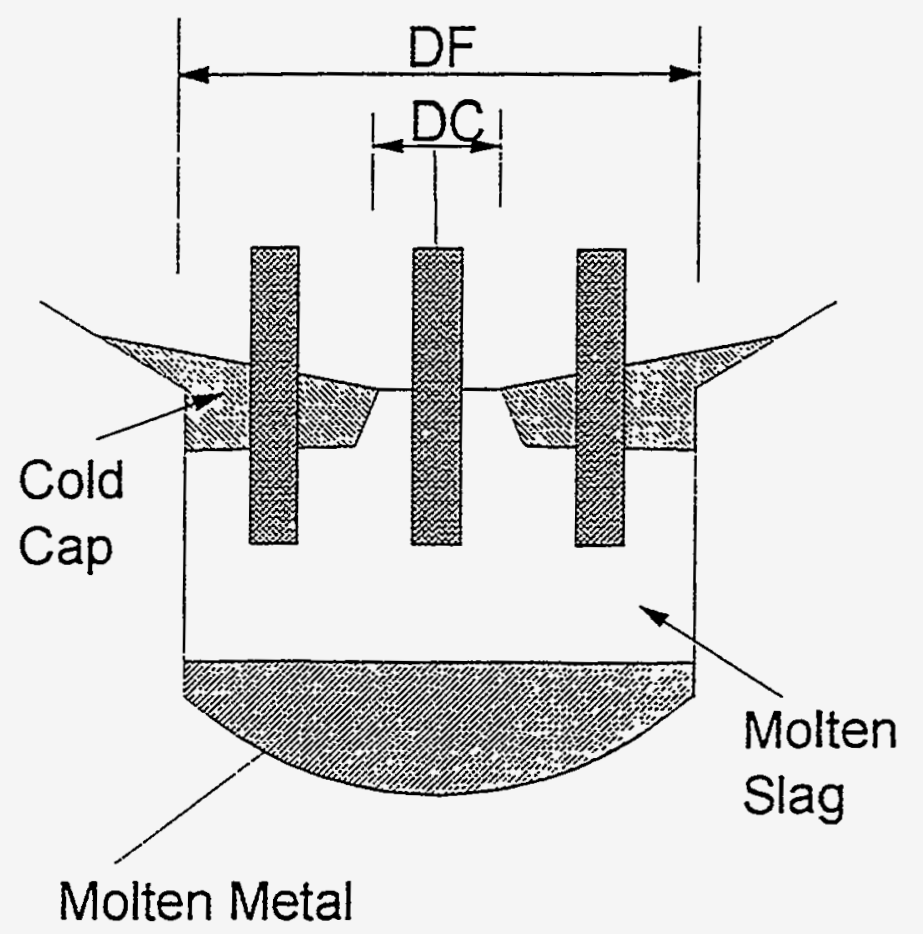




\section{Appendix C}

\section{Offgas Design Subcommittee Report}


Mr. Nick Soelberg

Engineering Specialist

Lockheed Idaho Technologies Co.

P.O. Box 1625

Idaho Falls, ID 83415

Report of the Thermal Oxidation/Offgas Subcommittee

of the IWTP Technical Review Meeting

Dear Mr. Soelberg:

The attached report documents the results of the deliberations of the Thermal Oxidation/Offgas subcommittee reviewing the Idaho Waste Treatment Program preliminary conceptual design. The subcommittee was made up of the following: Dr. Randy Seeker, EER Corp; Dr. Larry Waterland, Acurex Corp.; Mr. David Pitts, Focus Environmental; Mr. Dan Burns, Savannah River Site; Dr. C.C. Lee, USEPA, RREL; Mr. Fred Feizollahi, Morrison Knudsen Corp.; and Mr. John McFee, IT Corporation.

In general, the subcommittee found the problem to be a very difficult one, and the proposed design to be conservatively selected. The attached report contains two suggestions for enhanced process performance. One suggestion is a design issue in that a "leveling" of offgas flows will enhance performance of the air pollution control system. The second suggestion arises from Dr. Seeker's involvement with anticipated regulatory changes, which favor wet offgas cleaning systems.

The subcommittee also made several programmatic suggestions arising from our combined experience. These are presented here for consideration, but are only given as suggestions.

It has been an honor to participate in such a distinguished panel. My co-chair and I congratulate the Lockheed personnel on their openness to review and hope the program benefits from the comments.

Respectfully submitted,

IT CORPORATION

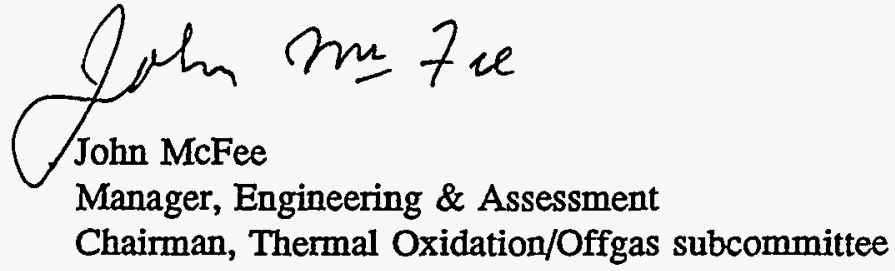

JNM:LW:rdr

Attachments
Acurex Environmental Corporation

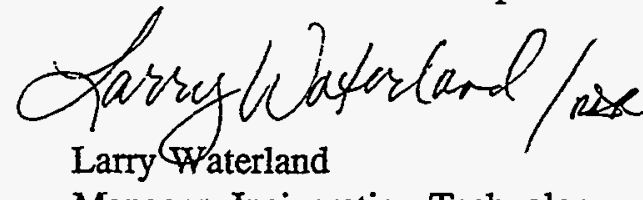

Manager, Incineration Technology

Development Programs

Co-chair, Thermal Oxidation/Offgas

subcommittee 
Distribution:

Mr. Dan Bums, Westinghouse Savannah River Company

Mr. Fred Feizollahi, Morrison Knudsen Corporation

Ms. Heather Holmes-Burns, Westinghouse Savannah River Company

Dr. C. C. Lee, US EPA

Mr. John McFee, IT Corporation

Mr. David Pitts, Focus Environmental

Dr. Randy Seeker, EER Corporation

Mr. Larry Waterland, Acurex Corp. 


\section{Idaho Waste Treatment Project Technical Advisory Committee Thermal Oxidation/Offgas Subcommittee Report}

\section{Introduction}

The Technical Review Meeting was introduced with the statement, "The purpose of this Technical Review Meeting is to provide feedback on the preliminary design so that the IWTP can proceed with the next phase of design. ..."

The scope of this subcommittee includes the "pyrolyzer," or thermal pretreatment step for the melter, the afterburner, and the air pollution control system.

The Thermal Oxidation/Offgas subcommittee discussed this purpose and arrived at three levels of comments. The first level of comments were those relating to programmatic issues which were felt to be program "givens" but which the subcommittee questioned in some fashion. In fact, several such issues were identified and are discussed below. The second level of comments were technical "show stopper" issues or items which the reviewers felt would significantly impact the operability, permittability, or safety of the proposed system. The last level of comments are those which the reviewers recommend as potential improvements or considerations which may be of value.

In reality, the subcommittee found the design to be technically sound, and characterized the air pollution control system as "state of the art." The comments that follow are in the form of either questions for consideration or indications of additional information that should be considered in the design.

The IWTP staff presentations resulted in considerable discussion and ultimately an understanding of the program and associated constraints. Since no design guidance or functional and operational requirements have been formally developed, the subcommittee interpreted the following to be "ground rules" that the design has proceeded under:

- Utilize the most robust waste form for actinide and hazardous metal immobilization

- Maximize volume reduction

- Destroy organics

- Rely on demonstrated technologies or those in industrial use

- $\quad$ Avoid mixed waste scrubber solutions.

Operating under the constraints of these guidelines, the design team has made numerous decisions which the subcommittee understood.

- Selection of Iron Enriched Basalt as the final waste form

- Selection of fixed hearth melting as the basic unit operation

- Conservative design philosophy such as inclusion of a pyrolyzer as a melter preprocessor

- Selection of a dry/wet APCS system

- Selection of range of waste compositions for mass and energy balance calculations

- Recognition of the need to include monitoring and controls in the evaluations

- Recognition of inleakage as a design issue. 


\section{$\underline{\text { Programmatic Issues }}$}

The highest level of comment that the incinerator/offgas treatment subcommittee identified are those programmatic issues that are not technical, but are significant success factors based on the experience of the various members. These comments are not truly "in scope" of our technical review, but are included here as suggestions.

- Regulators and stakeholders need to be involved at this time.

This point was made by all subcommittee members. In the current climate of environmental management and regulation, the regulators and stakeholders concerns must be included in the earliest stage of technical design of the facility. Although the program has taken a very conservative posture in recommending a robust waste form, it should not be assumed that this would meet with stakeholder acceptance. The concept of "early and frequent" contact with the stakeholders is recommended.

Waste characterization need/capability must be addressed and presented to the regulatory agencies.

Characterization of mixed waste is a difficult task, involving potential radiation dose exposures to the staff and considerable expense to the program. This fact is complicated by the unknown composition of the wastes to be treated. The experience of the panel members in hazardous waste incinerator operation is that regulatory personnel will demand a degree of characterization to ensure that all wastes processed can be demonstrated to be within the envelope defined by the trial burn. The subcommittee understands that such characterization on retrieved "trash" is extremely difficult and potentially hazardous, and the subcommittee recommends that this issue be addressed with the regulators as soon as a sampling plan can be proposed for discussion balancing detailed characterization against the principles of ALARA. (A recommendation was also made that the newly created EPA/DOE Interagency Work Group could be a vehicle for addressing this issue. Dr. C.C. Lee, of this subcommittee, is a member of that group.)

- A programmatic decision on the maintenance philosophy must be made (remote maintenance versus contact maintenance).

The subcommittee was unclear on whether contact maintenance would be allowed in this facility. Since this decision impacts the selection of components (such as baghouses), it should be decided quickly.

Typical safety analysis issues such as identification of criticality controls and other safety issues affecting design must be identified.

The subcommittee recognizes that safety analyses dictate design features in nuclear facilities. Some safety analyses conclusions could dictate processing system design selection, such as the acceptability of a wet offgas system. It is recommended that these issues be identified quickly to assure that the program does not go too far in the design/procurement schedule with components that could eventually be ruled unacceptable.

- A "real" waste acceptance criteria is needed to ensure that the iron enriched basalt (IEB) assumption is justified and adequate. 
As mentioned above, the selection of Iron Enriched Basalt is understood to be a conservative selection. However, since no disposal site is identified, and the performance assessment of the disposal site will dictate the properties of the waste form, the subcommittee questions the selection from the perspective that it may be "overkill" or it may not meet the waste acceptance criteria of the disposal facility once it is known. (It was suggested by IWTP personnel that performance criteria have been developed in another INEL program, and perhaps those criteria could be identified and applied here.)

\section{Technical Design Issues}

The subcommittee found no "showstopper" issues in the technical design. In all cases the design logic was considered sound with good engineering bases explained by the presenters. The subcommittee comments on the three process components within our technical area are individually discussed.

\section{Pyrolyzer Design Issues}

The discussion of the design issues relative to the pyrolyzer is prefaced with the understanding that the subcommittee found no compelling reason to say whether the pryrclyzer is required for success of the facility. The general belief was that if the melter could accept the unprocessed waste, then the pyrolyzer should be deleted from the design. However, the subcommittee cautions that acceptable melter performance for high-organic-content wastes needs to be verified, and may prove problematic. The subcommittee recommends that provision for a pyrolyzer be included, its benefit being that it will allow smoothing the composition variability of the feed to the melter, thereby allowing for more stable and controllable melter operation. If the pyrolyzer was judged necessary, then the following issue applies:

\section{- Selection of rotary kiln.}

The complex and unknown nature of the waste to be processed is consistent with selection of a rotary kiln. The selection appears to be appropriate with the caution that common kiln seals are not adequate for this application for contamination control or for control of inleakage.

\section{- Oxidative versus pyrolytic operations.}

Some discussion favored oxidative operation of the kiln over pyrolytic. Since the general conclusion that the kiln could be deleted was known at the time of the thermal oxidation/offgas subcommittee discussions, it was not considered at length. A significant issue relative to this decision is the ability for the melter to accept and to process fired carbon from the waste. An oxidative kiln will reduce fixed carbon to much lower levels than a pyrolytic one. (Steam injection was proposed as an altemate method to reduce fixed carbon content of the pyrolyzed waste, though use of this method was not uniformly endorsed by the entire subcommittee.) There was no agreement on the part of the melter subcommittee as to the acceptability of residual carbon in the slag, and therefore the thermal oxidation/offgas subcommittee did not dwell on this issue.

\section{- Potential slagging with high sodium wastes.}

Some of the waste packages are expected to contain high levels of alkali metals. These wastes typically have lower melting points and can attack the kiln refractory. The selection of an $1800^{\circ} \mathrm{F}$ operating temperature should be reconsidered. Complete burnout of fixed carbon can be enhanced by 
increased temperature or increased residence time. Most subcommittee members felt that a $1,600^{\circ} \mathrm{F}$ kiln exit gas temperature would be sufficient for effective organic constituent and fixed carbon burnout, while avoiding potential slagging problems. (Note that a $300^{\circ} \mathrm{F}$ temperature difference between the gas and solids in a kiln is common.) Thus, this choice of lower temperatures with a commensurate increase in residence time could enhance operation.

\section{Pyrolyzer Operation Conclusions}

In summary, the thermal oxidation/offgas subcommittee felt that the need of a pyrolyzer is a melter design issue. A rotary kiln will work, and oxidative operation would result in less fixed carbon in the melter feed. It is also recommended that the operating temperature selection be reconsidered and a temperature of $1600^{\circ} \mathrm{F}$ may be more appropriate.

\section{Afterburner Design Issues}

\section{- Excess oxygen selection.}

It is the subcommittee's general experience that $10 \%$ stoichiometric excess oxygen in incineration systems is generally not adequate for good destruction, and this is complicated in the IWTP system because of the heterogeneity of the feed. However, since the design includes oxygen for combustion and the use of exhaust gas recycle for temperature control, our "benchmarks" may not be appropriate. The actual selection of the excess oxygen level in the system will have to be determined in the pilot plant. However, most subcommittee members felt that having a $100 \%$ excess of oxygen would significantly enhance residual carbon levels in the ash and minimize residual organics in the combustion gases. The use of exhaust gas recycle for temperature control was discussed from a controls perspective, and thought to be acceptable.

\section{- Use of oxygen in fuel burner.}

Oxygen bumers are commercially available and should be an acceptable choice.

- Use of a plasma torch to replace the fuel burner in the secondary combustion chamber.

The subcommittee did not have any experience with plasmas as heat sources in a secondary combustion device. Although it reduces offgas flows, the subcommittee was uncertain that the required destruction of organics could be achieved. Secondary combustion chamber operation is critical to meeting organic destruction requirements, and conventional thermal oxidizer designs are well developed. High Combustion efficiency in the secondary combustion chamber also contributes to reduced dioxin formation by ensuring complete burnout of carbonaceous particles. Unburned particulate has been correlated with dioxin formation. The use of an untested concept for this critical step in the process seems inconsistent with the conservative engineering postures used in other IWTP component selections.

- The mass and energy balances need to be reconsidered with a goal of leveling the air pollution control system (APCS) flows via a constant Btu feed rate to the system.

Proper organic destruction in the secondary combustion system is a function of time, temperature, mixing, and excess oxygen. The mass and energy balances presented to the panel showed a six fold 
change in off gas flows to the secondary combustion system and the subsequent offgas system. These flows must be "leveled" to ensure efficient operation for all waste streams. The subcommittee comment that "incinerators burn Btus and not pounds" was meant to indicate that if constant waste energy is fed to the system, offgas flows will be leveled as well.

\section{Afterburner Conclusions}

A significant recommendation from the Thermal Oxidation/Offgas subcommittee is that the gas flows to the afterburner (secondary combustion chamber) and subsequent components must be leveled to a $2 / 1 \mathrm{max} / \mathrm{min}$ ratio if efficient operation is to be expected. The simplest approach to this leveling is to use the feed characterization to provide a constant energy feed input to the system, or to use auxiliary fuel for constant heat input, with increased exhaust gas recycled (EGR) for temperature control.

The afterburner can be fired using a commercial oxygen bumer, and $100 \%$ excess oxygen is used in conventional designs.

\section{APCS System Design Issues}

- Dry/wet offgas systems and dioxin formation.

We again state that the selection of a dry/wet offgas system configuration is a state of the art design. However, subcommittee members are involved with data collection and discussions related to dioxin regulations, and significant changes are expected. Data available to the subcommittee suggests that dioxin levels of less than $0.1 \mathrm{ng} / \mathrm{dscm}$ in a 2, 3, 7, 8-TCDD toxicity equivalent (TEQ) basis are achievable and has been proposed by the EPA as a target control level. These levels have been achieved by incinerators with rapid and total quench systems as their first air pollution control system component. Temperatures less than $400^{\circ} \mathrm{F}$ will be necessary to meet the anticipated regulations.

However, rapid and initial quenching to temperatures below $200^{\circ}$ may be necessary. The emission data currently available clearly show that the lowest dioxin emission levels are from systems that have a water quench to saturation as the initial post-combustion unit operation. Alternatively, large activated carbon absorption beds on the discharge could meet the regulation. A paper by Dr. Seeker (attached) presents some of the background for this regulatory issue.

The potential for high temperature filtration of the offgas was also presented as an alternative for dioxin controls. A copy of that paper is also attached.

- A total quench is also more favorable for a mercury capture prior to the final activated carbon beds.

Mercury is condensed at the temperatures of the wet scrubbing system. It can then be captured as metallic mercury or adsorbed from the soiution. The subcommittee also understands that the use of a $\mathrm{dry} /$ wet offgas system has implications from a radioactive waste processing perspective. The dry system has the advantage of reducing the criticality problem that a wet offgas system presents with fissionable materials. A disadvantage is that the baghouse is a high maintenance item and 
maintenance is difficult due to the radioactive particulate materials present. INEL's WERF incinerator has a baghouse which was safely maintained (contact maintenance) and is therefore considered an acceptable risk.

\section{APCS System Conclusions}

Assuming criticality is not a problem, dioxin and mercury control favor a total quench immediately after the afterburner. If a total quench is used, then high efficiency entrainment separation and reheat prior to a baghouse would be needed. Alternatively, a high-performance wet scrubber system could be used for final particulate, hazardous metal, and radionuclide control. High-performance systems, such as a HydroSonics scrubber or the Calvert scrubber system have particulate removal performance that is similar to baghouses. If these high-performance systems are followed by a wet electrostatic precipitator, they become the equal, if not the better, of dry baghouse systems. The resulting scrubber system blowdown discharge can be further processed by a crystallizer/evaporator if a final, dry radionuclide-contaminated residue is desired, although this dried residue would contain all the flue gas halides collected by the scrubber system.

In summary, the choice of dry/wet, wet/dry, or all wet APCS represents a tradeoff. The dry/wet system collects radionuclides, a dry particulate with minimal halide contamination, and avoids a radionuclidecontaminated halide-containing water discharge. A wet APCS enhances compliance with stringent dioxin and mercury emission limitations. 
Appendix D

Offgas System Mass and Energy Balance Calculations 


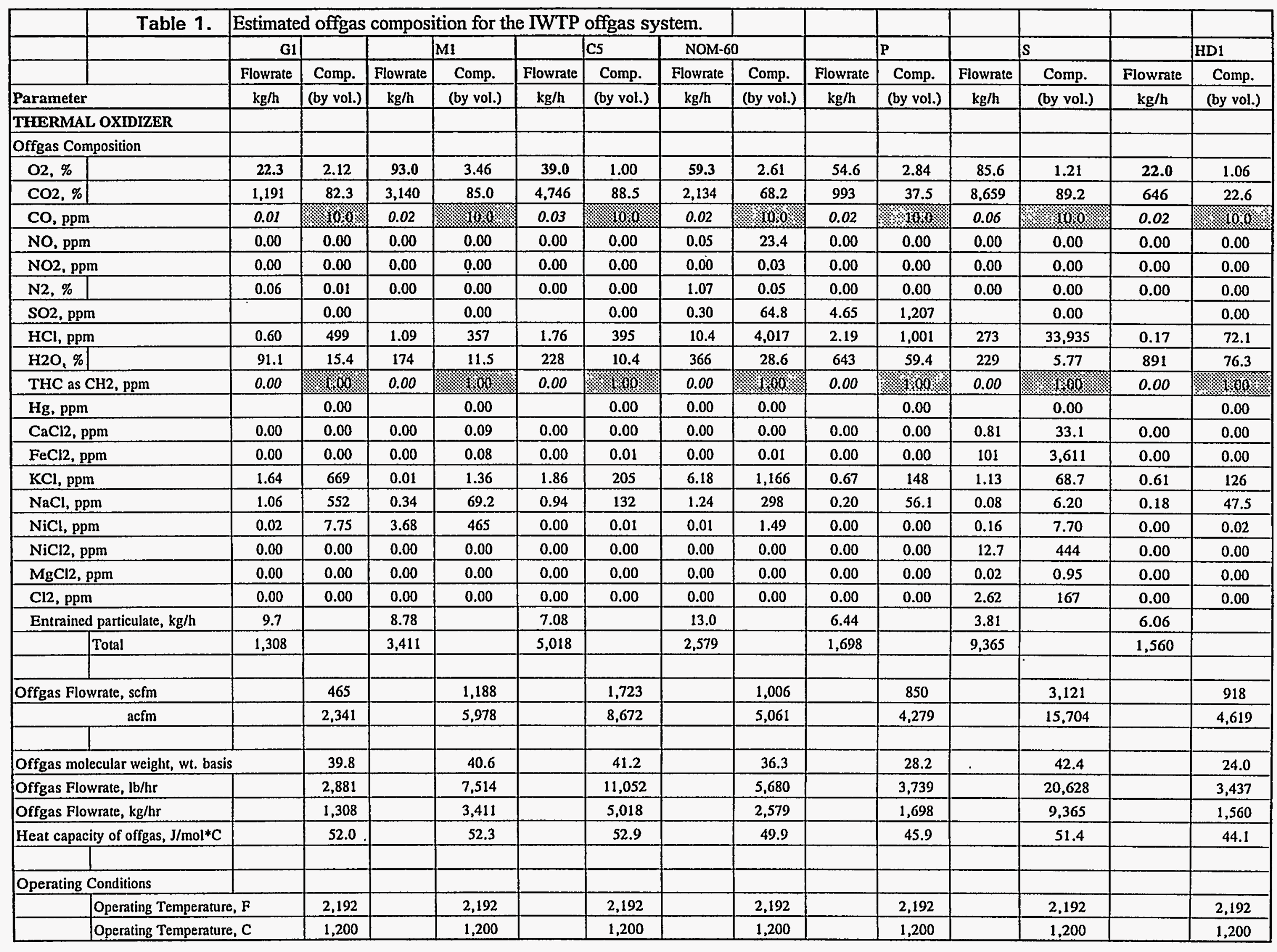




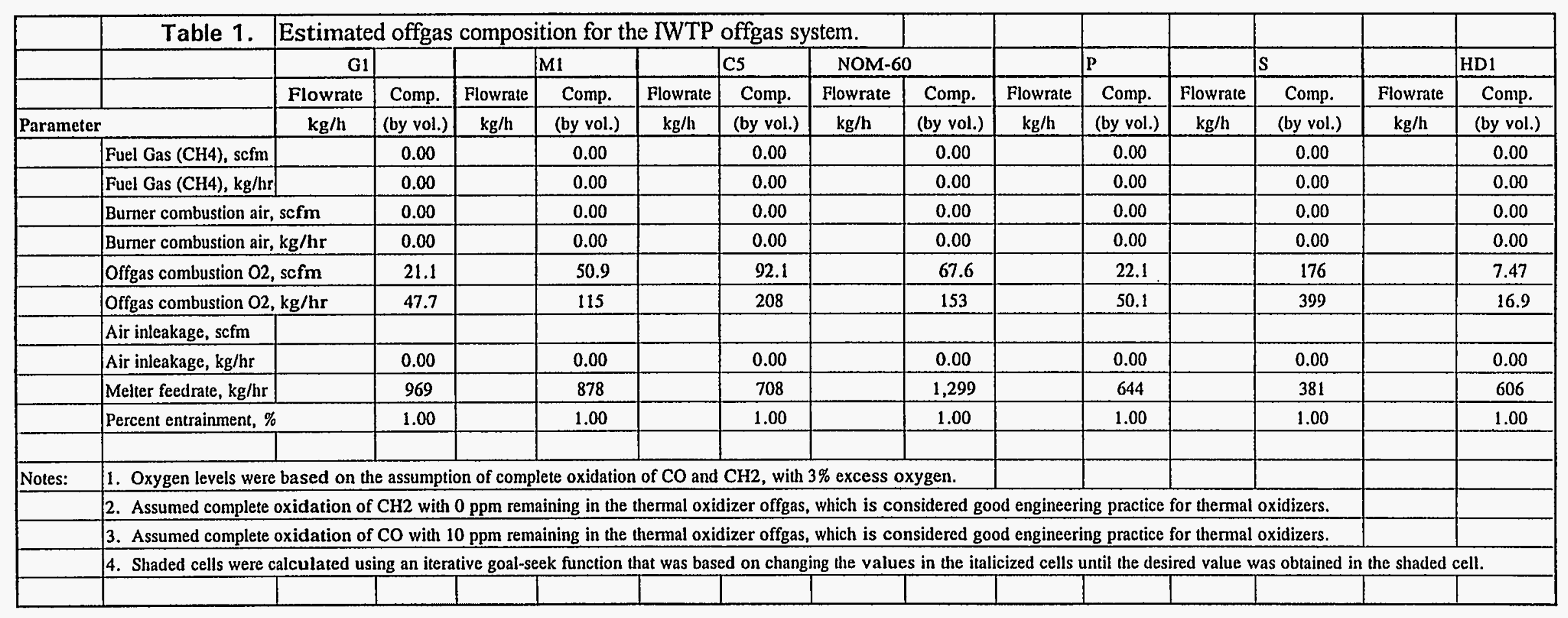


$\varepsilon$

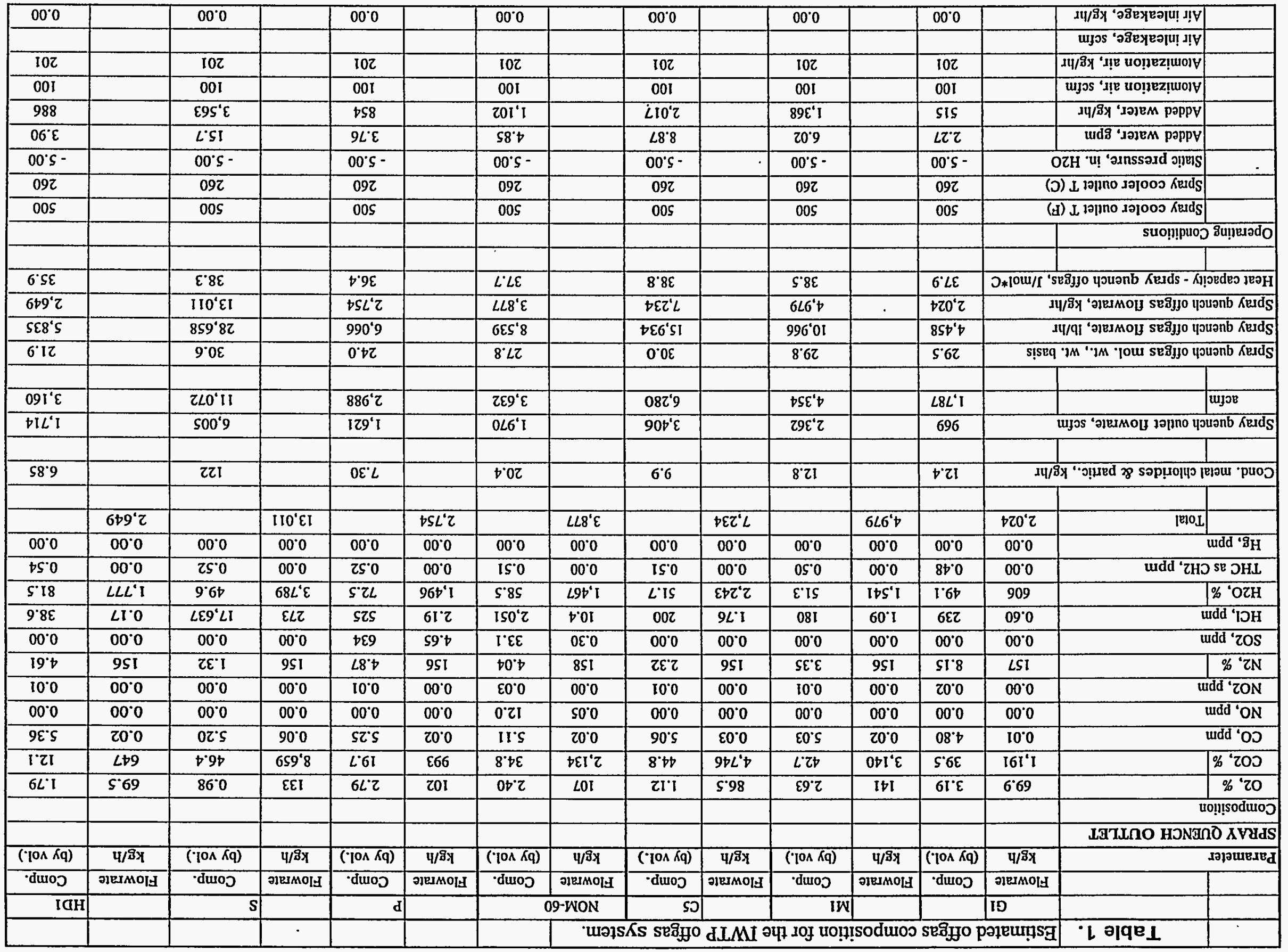




\begin{tabular}{|c|c|c|c|c|c|c|c|c|c|c|c|c|c|c|c|}
\hline & & & & & & & & & & & & & & & \\
\hline $00 \%$ & & $00^{\circ} 0$ & & 000 & & $00^{\circ} 0$ & & 000 & & $00^{\circ} 0$ & & $00^{\circ} 0$ & & 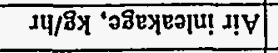 & \\
\hline & & & & & & & & & & & & & & 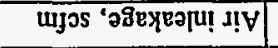 & \\
\hline I6z't & & $080^{\circ} 91$ & & $6 I I^{\prime} \mathrm{b}$ & & $88 I^{\prime} \mathrm{s}$ & & $122^{\prime} 6$ & & $9 b \varepsilon^{4} 9$ & & $99 s^{\prime} z$ & & 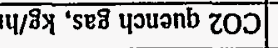 & \\
\hline 6LE'I & & 691's & & $t z \varepsilon^{\prime} l$ & & $899^{\prime} I$ & & $p 96^{\prime} z$ & & $000^{\circ} z$ & & 528 & & 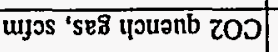 & \\
\hline$\angle S 8^{\top} \bar{\varepsilon}$ & & $9 S t^{4}+1$ & & $\varepsilon L^{\prime} \varepsilon$ & & $799^{\prime} t$ & & $06 z^{\prime} 8$ & & SOL'S & & $\angle O E^{\prime} Z$ & & 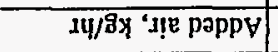 & \\
\hline $916^{\prime} 1$ & & $181^{\prime} \mathrm{L}$ & & $0+8^{\prime} 1$ & & LIE'? & & $8 \pi T^{\prime} t$ & & $\Rightarrow E 8^{\prime} Z$ & & $9 b l^{\prime} I$ & & uujos 's!e pappy & \\
\hline $\mathrm{I}$ & & 1 & & $I$ & & $I$ & & $i$ & & $I$ & & 1 & & onb $(1)$ zOJ so (0) म19 & \\
\hline $00 \%$ & & $00 . \mathrm{s}-$ & & $00 \%-$ & & $00^{\circ} \mathrm{s}^{-}$ & & $005^{-}$ & & $00^{\circ} \mathrm{s}^{-}$ & & $005^{-}$ & & 2zH 'u! 'annssard ongers & \\
\hline 6tI & & $6 \mathrm{bI}$ & & $6 \mathrm{bl}$ & & $6+1$ & & $66 I$ & & 601 & & 601 & & (D) L I & \\
\hline $00 \varepsilon$ & & $00 E$ & & $00 \varepsilon$ & & $00 \varepsilon$ & & $00 \varepsilon$ & & $00 \varepsilon$ & & $00 \varepsilon$ & & 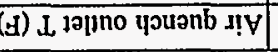 & \\
\hline & & & & & & & & & & & & & & suop!puos & 8uperado \\
\hline & & & & & & & & & & & & & & & \\
\hline $0+6^{\prime} 9$ & & $160^{\prime} 6 \tau$ & & $\varepsilon \angle 8^{\top} 9$ & & $590^{\circ} 6$ & & SSD'9I & & $D Z E^{\prime} I I$ & & $06 s^{\prime} t$ & & 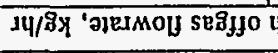 & youənb J!v \\
\hline $98 Z^{\prime} s I$ & & $9 \angle 0^{\prime}+9$ & & OPI'SI & & $996^{\prime} 61$ & & $\$ p z^{i} 9 \varepsilon$ & & $606^{\prime} 72$ & & III'OI & & 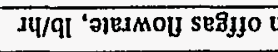 & पวuanb d!V \\
\hline$L^{\prime} \tau \varepsilon$ & & $8.9 \varepsilon$ & & $0^{\circ} \varepsilon E$ & & $\tau ' s \varepsilon$ & & $59 \varepsilon$ & & $6 \cdot 9 \varepsilon$ & & $2.9 \varepsilon$ & & 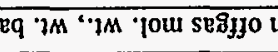 & पวuวnb $\mathrm{I!V}$ \\
\hline & & & & & & & & & & & & & & & \\
\hline$D I S^{\prime} \phi$ & & $60 \varepsilon^{\prime} 91$ & & $86 z^{\prime} t$ & & $60 \varepsilon^{\prime} s$ & & $862^{\prime} 6$ & & $t z t^{\prime} 9$ & & $619^{\prime} \mathrm{Z}$ & & & wijot \\
\hline$\varepsilon 60^{\circ} \varepsilon$ & & $\nabla L I ' I I$ & & $S p 66^{\prime} z$ & & $8 \varepsilon 9^{\star} \varepsilon$ & & ILE'9 & & $20 b^{2} t$ & & $\$ 6 \iota^{\prime} t$ & & 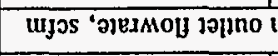 & upuanb s!v \\
\hline & & & & & & & & & & & & & & & \\
\hline & $0+\sigma^{\prime} 9$ & & $160^{\circ} 62$ & & $\varepsilon \angle 8^{\prime} 9$ & & $590^{\circ} 6$ & & SSD'9I & & $\not Z E^{\prime} I I$ & & $06 s^{4} t$ & |810L & \\
\hline $00 \%$ & $00^{\circ} 0$ & $00^{\circ} 0$ & $00^{\circ} 0$ & $00^{\circ} 0$ & $00 \%$ & 000 & $00 \%$ & $00^{\circ} 0$ & $00 \%$ & $00^{\circ} 0$ & $00^{\circ} 0$ & $00^{\circ} 0$ & $00^{\circ} 0$ & & udd '9H \\
\hline $0 \varepsilon^{\prime} 0$ & $00^{\circ} 0$ & $82^{\circ} 0$ & $00^{\circ} 0$ & $62^{\prime} 0$ & 00.0 & $82^{\circ} 0$ & $00 \%$ & $\angle 2 \cdot 0$ & $00^{\circ} 0$ & $\angle 2 \cdot 0$ & $00^{\circ} 0$ & 920 & 00.0 & udd ' $\mathrm{ZHO}$ & SR JHL \\
\hline $15 t$ & $\angle L L^{\prime} \mathrm{I}$ & 9.92 & $68 L^{\prime} \varepsilon$ & $6.6 \varepsilon$ & $966^{\circ} 1$ & L'IE & $\angle 9 b^{\prime} I$ & $L \angle Z$ & Ept'z & $S \cdot L z$ & $I t S^{\prime} I$ & 592 & 909 & & $\%$ 'OZH \\
\hline $6 \cdot 12$ & $\angle I^{\circ} 0$ & $8 \angle D^{\prime} 6$ & $\varepsilon L \tau$ & 682 & $6 I^{\prime} z$ & III'I & 501 & LOI & $9 L^{\prime} I$ & 5.96 & $60^{\circ} I$ & 621 & $09^{\circ} 0$ & & udd 'IDH \\
\hline $00^{\circ} 0$ & $00^{\circ} 0$ & $00^{\circ} 0$ & $00^{\circ} 0$ & $6+\varepsilon$ & $s 9^{\circ} \mathrm{b}$ & 6.21 & $O E^{\prime} 0$ & 000 & $00^{\circ} 0$ & $00^{\circ} 0$ & $00^{\circ} 0$ & $00^{\circ} 0$ & $00^{\circ} 0$ & & udd 'zos \\
\hline$S S^{\prime} z$ & $9 \mathrm{SI}$ & $I L^{\prime} 0$ & 9 9SI & $89^{\circ} \mathrm{Z}$ & $9 S I$ & 612 & $8 \mathrm{SI}$ & $t \tau \cdot \tau$ & 9 SI & $6 L^{\prime} 1$ & 951 & $0 b^{\prime} t$ & $L S I$ & & $\%$ ' $\mathrm{N}$ \\
\hline 10.0 & $00 \%$ & $00^{\circ} 0$ & $00^{\circ} 0$ & $10^{\circ} 0$ & 00.0 & $10^{\prime} 0$ & $00 \%$ & $00^{\circ} 0$ & $00^{\circ} 0$ & $00^{\circ} 0$ & 00.0 & $10^{\circ} 0$ & $00^{\circ} 0$ & & ddd 'rON \\
\hline $00^{\circ} 0$ & 00.0 & $00^{\circ} 0$ & $00^{\circ} 0$ & $00^{\circ} 0$ & $00^{\circ} 0$ & $8 b^{\prime} 9$ & 50.0 & $00 \%$ & $00 \%$ & $00^{\circ} 0$ & $00^{\circ} 0$ & $00^{\circ} 0$ & $00^{\circ} 0$ & & und 'ON \\
\hline$\angle 6 \cdot Z$ & $20^{\circ} 0$ & $6 L 2$ & $90^{\circ} 0$ & $68^{\prime} z$ & 20.0 & $\angle L^{\prime} Z$ & $20 \% 0$ & $I L^{\prime} Z$ & $\varepsilon 0^{\circ} 0$ & $0 L^{\prime} Z$ & $20^{\circ} 0$ & $6 s^{\prime} \tau$ & 100 & & undd 'os \\
\hline$\varepsilon \cdot I S$ & $\angle E \sigma^{\prime} b$ & 2.12 & $6 \varepsilon L^{\prime} \not \tau$ & $8 . S S$ & ZII'S & L'\$9 & $Z Z E^{\prime} L$ & $S^{\prime} 0 L$ & $\angle 96^{\circ} \varepsilon I$ & $\varepsilon^{\prime} 69$ & $58 b^{\prime} 6$ & $\varepsilon^{\prime} \angle 9$ & $L S L^{\prime} \varepsilon$ & & $\%$ '200 \\
\hline $66^{\circ} 0$ & $5^{\prime} 69$ & $E S^{\circ} 0$ & EEI & $\varepsilon S^{\prime} I$ & 201 & $O E^{\prime} I$ & LOI & $09^{\circ} 0$ & S.98 & $I t I$ & $I D I$ & $Z L^{\prime} I$ & 6.69 & & $\%$ '20 \\
\hline & & & & & & & & & & & & & & & ou!nsoduroJ \\
\hline & & & & & & & & & & & & & & LGTLIOO HJN & Nand มIV \\
\hline$(10 \wedge \mathrm{Kq})$ & $4 / 8 y$ & $(\cdot \mid 0 \wedge k q)$ & $1 / / 8 y$ & $(\bar{c}(1) K q)$ & $4 / 89$ & $(10 \wedge k q)$ & $4 / 8 y$ & $(\mathrm{TO \Lambda} K q)$ & $4 / 8 x$ & $(" \operatorname{los} K q)$ & $4 / 8 \%$ & $(\cdot 10 n K q)$ & $4 / 8 x$ & & 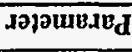 \\
\hline duroj & गืยल० & duroj & गएय MOP & duos & गुEIMO|d & duoj & गJEMOII & duoj & 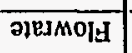 & duroj & ग्सMOIH & -duoj & गUसMOIH & & \\
\hline IaH & & $\underline{s}$ & & d & & \multicolumn{2}{|r|}{ 09-WON } & SD & & IW & & & 10 & & \\
\hline & & & & & & & \multicolumn{7}{|c|}{ 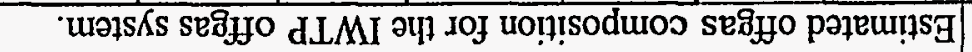 } & 'l әवा 1 & \\
\hline
\end{tabular}




\begin{tabular}{|c|c|c|c|c|c|c|c|c|c|c|c|c|c|c|c|}
\hline & \multirow[t]{2}{*}{ Table 1.} & \multicolumn{8}{|c|}{ Estimated offgas composition for the IWTP offgas system. } & & \multirow[b]{2}{*}{$\mathrm{p}$} & & \multirow[b]{2}{*}{$\mathrm{s}$} & & \multirow[b]{2}{*}{ HD1 } \\
\hline & & G1 & & & M1 & & C5 & NOM-6 & & & & & & & \\
\hline & & Flowrate & Comp. & Flowrate & Comp. & Flowrate & Comp. & Flowrate & Comp. & Flowrate & Comp. & Flowrate & Comp. & Flowrate & Comp. \\
\hline \multicolumn{2}{|l|}{ Parameter } & $\mathrm{kg} / \mathrm{h}$ & (by vol.) & $\mathrm{kg} / \mathrm{h}$ & (by vol.) & $\mathrm{kg} / \mathrm{h}$ & (by vol.) & $\mathrm{kg} / \mathrm{h}$ & (by vol.) & $\mathrm{kg} / \mathrm{h}$ & (by vol.) & $\mathrm{kg} / \mathrm{h}$ & (by vol.) & $\mathrm{kg} / \mathrm{h}$ & (by vol.) \\
\hline \multicolumn{16}{|c|}{ CYCLONE } \\
\hline \multicolumn{16}{|c|}{ Offgas Composition } \\
\hline $02, \%$ & & 69.9 & 1.72 & 141 & 1.41 & 86.5 & 0.60 & 107 & 1.30 & 102 & 1.53 & 133 & 0.53 & 69.5 & 0.99 \\
\hline $\mathrm{CO} 2, \%$ & & 3,757 & 67.3 & 9,485 & 69.3 & 13,967 & 70.5 & 7,322 & 64.7 & 5,112 & 55.8 & 24,739 & 71.2 & 4,937 & 51.3 \\
\hline \multicolumn{2}{|l|}{$\mathrm{CO}, \mathrm{ppm}$} & 0.01 & 2.59 & 0.02 & 2.70 & 0.03 & 2.71 & 0.02 & 2.77 & 0.02 & 2.89 & 0.06 & 2.79 & 0.02 & 2.97 \\
\hline \multicolumn{2}{|l|}{ NO, ppm } & 0.00 & 0.00 & 0.00 & 0.00 & 0.00 & 0.00 & 0.05 & 6.48 & 0.00 & 0.00 & 0.00 & 0.00 & 0.00 & 0.00 \\
\hline \multicolumn{2}{|c|}{ NO2, ppm } & 0.00 & 0.01 & 0.00 & 0.00 & 0.00 & 0.00 & 0.00 & 0.01 & 0.00 & 0.01 & 0.00 & 0.00 & 0.00 & 0.01 \\
\hline N2, \% & & 157 & 4.40 & 156 & 1.79 & 156 & 1.24 & 158 & 2.19 & 156 & 2.68 & 156 & 0.71 & 156 & 2.55 \\
\hline \multicolumn{2}{|c|}{ SO2, ppm } & 0.00 & 0.00 & 0.00 & 0.00 & 0.00 & 0.00 & 0.30 & 17.9 & 4.65 & 349 & 0.00 & 0.00 & 0.00 & 0.00 \\
\hline \multicolumn{2}{|c|}{$\mathrm{HCl}, \mathrm{ppm}$} & 0.60 & 129 & 1.09 & 96.4 & 1.76 & 107 & 10.4 & 1,111 & 2.19 & 289 & 273 & 9,478 & 0.17 & 21.4 \\
\hline $\mathrm{H} 2 \mathrm{O}, \%$ & & 606 & 26.5 & 1,541 & 27.5 & 2,243 & 27.7 & 1,467 & 31.7 & 1,496 & 39.9 & 3,789 & 26.6 & 1,777 & 45.1 \\
\hline \multicolumn{2}{|c|}{ THC as $\mathrm{CH} 2, \mathrm{ppm}$} & 0.00 & 0.26 & 0.00 & 0.27 & 0.00 & 0.27 & 0.00 & 0.28 & 0.00 & 0.29 & 0.00 & 0.28 & 0.00 & 0.30 \\
\hline \multicolumn{2}{|l|}{$\mathrm{Hg}, \mathrm{ppm}$} & 0.00 & 0.00 & 0.00 & 0.00 & 0.00 & 0.00 & 0.00 & 0.00 & 0.00 & 0.00 & 0.00 & 0.00 & 0.00 & 0.00 \\
\hline & Total & 4,590 & & 11,324 & & 16,455 & & 9,065 & & 6,873 & & 29,091 & & 6,940 & \\
\hline \multicolumn{2}{|c|}{ Offgas Flowrate, scfm } & & 1,794 & & 4,402 & & 6,371 & & 3,638 & & 2,945 & & 11,174 & & 3,093 \\
\hline \multicolumn{2}{|r|}{ acfm } & & 2,652 & & 6,505 & & 9,415 & & 5,376 & & 4,352 & & 16,515 & & 4,571 \\
\hline \multicolumn{3}{|c|}{ Offgas molecular weight, wt. basis } & 36.2 & & 36.4 & & 36.5 & & 35.2 & & 33.0 & & 36.8 & & 31.7 \\
\hline \multicolumn{2}{|c|}{ Offgas Flowrate, lb/hr } & & 10,111 & & 24,944 & & 36,245 & & 19,966 & & 15,140 & & 64,076 & & 15,286 \\
\hline \multicolumn{2}{|c|}{ Offgas Flowrate, $\mathrm{kg} / \mathrm{hr}$} & & 4,590 & & 11,324 & & 16,455 & & 9,065 & & 6,873 & & 29,091 & & 6,940 \\
\hline & & & & & & & & & & & & & & & \\
\hline \multicolumn{16}{|c|}{ Operating Conditions } \\
\hline & \multicolumn{2}{|c|}{ Operating Temperature, $\mathrm{F}$} & 300 & & 300 & & 300 & & 300 & & 300 & & 300 & & 300 \\
\hline & \multicolumn{2}{|c|}{ Operating Temperature, $\mathrm{C}$} & 149 & & 149 & & 149 & & 149 & & 149 & & 149 & & 149 \\
\hline & \multicolumn{2}{|l|}{ Static pressure, in. $\mathrm{H} 2 \mathrm{O}$} & -10.00 & & -10.00 & & -10.00 & & -10.00 & & -10.00 & & -10.00 & & -10.00 \\
\hline & Efficiency, \% & & 10.0 & & 10.0 & & 10.0 & & 10.0 & & 10.0 & & 10.0 & & 10.0 \\
\hline & Solid residue, $\mathrm{kg} / \mathrm{hr}$ & & 1.24 & & 1.28 & & 0.99 & & 2.04 & & 0.73 & & 12.2 & & 0.69 \\
\hline & Air inleakage, scfm & & & & & & & & & & & & & & \\
\hline & Air inleakage, $\mathrm{kg} / \mathrm{hr}$ & & 0.00 & & 0.00 & & 0.00 & & 0.00 & & 0.00 & & 0.00 & & 0.00 \\
\hline & & & & & & & & & & & & & & & \\
\hline
\end{tabular}




\begin{tabular}{|c|c|c|c|c|c|c|c|c|c|c|c|c|c|c|c|}
\hline & \multirow[t]{3}{*}{ Table 1} & \multicolumn{7}{|c|}{ Estimated offgas composition for the IWTP offgas system. } & & \multirow{3}{*}{ Elowrate } & \multirow{2}{*}{$p$} & \multirow[b]{3}{*}{ Flowrate } & \multirow{3}{*}{ Somp. } & \multirow[b]{3}{*}{ Flowrate } & \multirow{3}{*}{\begin{tabular}{|l} 
HDI \\
Comp.
\end{tabular}} \\
\hline & & \multicolumn{2}{|l|}{ G1 } & \multicolumn{2}{|c|}{$\mathrm{Ml}$} & \multicolumn{2}{|c|}{\begin{tabular}{|l|l|}
$\mathrm{CS}$ \\
\end{tabular}} & \multicolumn{2}{|c|}{ NOM-60 } & & & & & & \\
\hline & & Flowrate & Comp. & Flowrate & Comp. & Flowrate & Comp. & Flowrate & Comp. & & Comp. & & & & \\
\hline \multicolumn{2}{|c|}{ Parameter } & $\mathrm{kg} / \mathrm{h}$ & (by vol.) & $\mathrm{kg} / \mathrm{h}$ & (by vol.) & $\mathrm{kg} / \mathrm{h}$ & (by vol.) & $\mathrm{kg} / \mathrm{h}$ & (by vol.) & $\mathrm{kg} / \mathrm{h}$ & (by vol.) & $\mathrm{kg} / \mathrm{h}$ & (by vol.) & $\mathrm{kg} / \mathrm{h}$ & (by vol.) \\
\hline \multicolumn{16}{|c|}{ BAGHOUSE } \\
\hline \multicolumn{16}{|c|}{ Offgas Composition } \\
\hline $02, \%$ & & 69.9 & 1.67 & 141 & 1.40 & 86.5 & 0.60 & 107 & 1.28 & 102 & 1.51 & 133 & 0.52 & 69.5 & 0.98 \\
\hline $\mathrm{CO} 2, \%$ & & 3,913 & 68.2 & 9,641 & 69.6 & 14,123 & 70.7 & 7,478 & 65.2 & 5,268 & 56.5 & 24,895 & 71.3 & 5,093 & 52.1 \\
\hline $\mathrm{CO}, \mathrm{ppm}$ & & 0.01 & 2.52 & 0.02 & 2.67 & 0.03 & 2.68 & 0.02 & 2.73 & 0.02 & 2.84 & 0.06 & 2.78 & 0.02 & 2.92 \\
\hline No, ppn & & 0.00 & 0.00 & 0.00 & 0.00 & 0.00 & 0.00 & 0.05 & 6.39 & 0.00 & 0.00 & 0.00 & 0.00 & 0.00 & 0.00 \\
\hline $\mathrm{NO} 2, \mathrm{pp}$ & & 0.00 & 0.01 & 0.00 & 0.00 & 0.00 & 0.00 & 0.00 & 0.01 & 0.00 & 0.01 & 0.00 & 0.00 & 0.00 & 0.01 \\
\hline $\mathrm{N} 2, \%$ & & 157 & 4.29 & 156 & 1.77 & 156 & 1.23 & 158 & 2.16 & 156 & 2.64 & 156 & 0.70 & 156 & 2.51 \\
\hline \multicolumn{2}{|c|}{ SO2, ppm } & 0.00 & 0.00 & 0.00 & 0.00 & 0.00 & 0.00 & 0.30 & 17.7 & 4.65 & 343 & 0.00 & 0.00 & 0.00 & 0.00 \\
\hline \multicolumn{2}{|c|}{$\mathrm{HCl}, \mathrm{ppm}$} & 0.60 & 126 & 1.09 & 95.3 & 1.76 & 106 & 10.4 & 1,096 & 2.19 & 284 & 273 & 9,436 & 0.17 & 21.1 \\
\hline $\mathrm{H} 2 \mathrm{O}, \%$ & & 606 & 25.8 & 1,541 & 27.2 & 2,243 & 27.5 & 1,467 & 31.3 & 1,496 & 39.2 & 3,789 & 26.5 & 1,777 & 44.4 \\
\hline \multicolumn{2}{|c|}{ THC as $\mathrm{CH} 2, \mathrm{ppm}$} & 0.00 & 0.25 & 0.00 & 0.27 & 0.00 & 0.27 & 0.00 & 0.27 & 0.00 & 0.28 & 0.00 & 0.28 & 0.00 & 0.29 \\
\hline \multicolumn{2}{|c|}{$\mathrm{Hg}, \mathrm{ppm}$} & 0.00 & 0.00 & 0.00 & 0.00 & 0.00 & 0.00 & 0.00 & 0.00 & 0.00 & 0.00 & 0.00 & 0.00 & 0.00 & 0.00 \\
\hline & Total & 4,746 & & 11,480 & & 16,611 & & 9,220 & & 7,029 & & 29,246 & & 7,095 & \\
\hline & & & & & & & & & & & & & & & \\
\hline \multicolumn{16}{|c|}{ Baghouse Residue Composition } \\
\hline \multicolumn{2}{|c|}{$\mathrm{CaCl} 2, \mathrm{ppm}$ (mass \%) } & 0.00 & 0.00 & 0.00 & 66.4 & 0.00 & 0.00 & 0.00 & 0.00 & 0.00 & 0.00 & 0.73 & 6,621 & 0.00 & 0.00 \\
\hline \multicolumn{2}{|c|}{$\mathrm{FeCl} 2, \mathrm{ppm}$ (mass \%) } & 0.00 & 0.00 & 0.00 & 66.4 & 0.00 & 10.1 & 0.00 & 4.90 & 0.00 & 0.00 & 90.8 & 825,629 & 0.00 & 0.00 \\
\hline $\mathrm{KCl}, \mathrm{pp}$ & $m$ (mass \%) & 1.47 & 132,162 & 0.01 & 664 & 1.67 & 188,332 & 5.56 & 302,643 & 0.60 & 91,096 & 1.02 & 9,237 & 0.55 & 89,011 \\
\hline $\mathrm{NaCl}, \mathrm{p}$ & pm (mass \%) & 0.95 & 85,422 & 0.31 & 26,517 & 0.85 & 95,178 & 1.11 & 60,724 & 0.18 & 26,986 & 0.07 & 654 & 0.16 & 26,265 \\
\hline $\mathrm{NiCl}, \mathrm{pp}$ & m (mass \%) & 0.02 & 1,934 & 3.31 & 287,347 & 0.00 & 10.1 & 0.01 & 490 & 0.00 & 0.00 & 0.14 & 1,308 & 0.00 & 14.6 \\
\hline $\mathrm{NiCl} 2$, & pm (mass \%) & 0.00 & 0.00 & 0.00 & 0.00 & 0.00 & 0.00 & 0.00 & 0.00 & 0.00 & 0.00 & 11.4 & 103,817 & 0.00 & 0.00 \\
\hline $\mathrm{MgCl}$, & ppm (mass \%) & 0.00 & 0.00 & 0.00 & 0.00 & 0.00 & 0.00 & 0.00 & 0.00 & 0.00 & 0.00 & 0.02 & 163 & 0.00 & 0.00 \\
\hline $\mathrm{Cl} 2, \mathrm{ppr}$ & $\mathrm{n}$ (mass \%) & 0.00 & 0.00 & 0.00 & 0.00 & 0.00 & 0.00 & 0.00 & 0.00 & 0.00 & 0.00 & 2.36 & 21,417 & 0.00 & 0.00 \\
\hline Entraine & d feed, ppm (mass \%) & 8.71 & 780,482 & 7.89 & 685,339 & 6.36 & 716,470 & 11.7 & 636,138 & 5.79 & 881,918 & 3.43 & 31,153 & 5.45 & 884,709 \\
\hline Offgas Flo & wrate, scfm & & 1,844 & & 4,452 & & 6,421 & & 3,688 & & 2,995 & & 11,224 & & 3,143 \\
\hline & $\mathrm{acfm}$ & & 2,654 & & 6,406 & & 9,240 & & 5,307 & & 4,310 & & 16,152 & & 4,523 \\
\hline 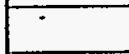 & & & & & & & & & & & & & & & \\
\hline Offgas mo & lecular weight, wt. basis & & 36.4 & & 36.5 & & 36.6 & & 35.4 & & 33.2 & & 36.9 & & 31.9 \\
\hline Offgas FlC & wrate, lb/hr & & 10,453 & & 25,286 & & 36,587 & & 20,309 & & 15,482 & & 64,419 & & 15,629 \\
\hline Offgas Flc & wrate, $\mathrm{kg} / \mathrm{hr}$ & & 4,746 & & 11,480 & & 16,611 & & 9,220 & & 7,029 & & 29,246 & & 7,095 \\
\hline Heat capa & ity of offgas, $\mathrm{J} / \mathrm{mol}^{*} \mathrm{C}$ & & 38.0 & & 38.2 & & 38.3 & & 37.9 & & 37.4 & & 38.1 & & 37.2 \\
\hline & & & & & & & & & & & & & & & \\
\hline Operating & Conditions & & & & & & & & & & & & & & \\
\hline
\end{tabular}




\begin{tabular}{|c|c|c|c|c|c|c|c|c|c|c|c|c|c|c|c|}
\hline & \multirow[t]{3}{*}{ Table 1.} & \multicolumn{7}{|c|}{ Estimated offgas composition for the IWTP offgas system. } & & & \multirow[b]{2}{*}{$\mathbf{P}$} & \multirow{2}{*}{\multicolumn{2}{|c|}{ s }} & \multirow[b]{3}{*}{ Flowrate } & \multirow{3}{*}{\begin{tabular}{|l} 
HD1 \\
Comp. \\
\end{tabular}} \\
\hline & & G1 & \multirow{2}{*}{\begin{tabular}{|l|} 
Comp. \\
\end{tabular}} & \multicolumn{2}{|c|}{\begin{tabular}{|l|l|}
$\mathrm{M} 1$ \\
\end{tabular}} & \multicolumn{2}{|r|}{ Cs } & \multicolumn{2}{|c|}{ NOM-60 } & \multirow{2}{*}{ Flowrate } & & & & & \\
\hline & & Flowrate & & Flowrate & Comp. & Flowrate & Comp. & Flowrate & Comp. & & Comp. & Flowrate & Comp. & & \\
\hline Parameter & & $\mathrm{kg} / \mathrm{h}$ & (by vol.) & $\mathrm{kg} / \mathrm{h}$ & (by vol.) & $\mathrm{kg} / \mathrm{h}$ & (by vol.) & $\mathrm{kg} / \mathrm{h}$ & (by vol.) & $\mathrm{kg} / \mathrm{h}$ & (by vol.) & $\mathrm{kg} / \mathrm{h}$ & (by vol.) & $\mathrm{kg} / \mathrm{h}$ & (by vol.) \\
\hline & \multicolumn{2}{|c|}{ Operating Temperature, F } & 280 & & 280 & & 280 & & 280 & & 280 & & 280 & & 280 \\
\hline & \multicolumn{2}{|c|}{ Operating Temperature, $\mathrm{C}$} & 138 & & 138 & & 138 & & 138 & & 138 & & 138 & & 138 \\
\hline & \multicolumn{2}{|l|}{ Static pressure, in. H2O } & -10.00 & & -10.00 & & -10.00 & & -10.00 & & -10.00 & & -10.00 & & -10.00 \\
\hline & \multicolumn{2}{|l|}{ Air inleakage, scfm } & & & & & & & & & & & & & \\
\hline & Air inleakage, $\mathrm{kg} / \mathrm{hr}$ & & 0.00 & & 0.00 & & 0.00 & & 0.00 & & 0.00 & & 0.00 & & 0.00 \\
\hline & Pulsed jet air, scfm & & 0.00 & & 0.00 & & 0.00 & & 0.00 & & 0.00 & & 0.00 & & 0.00 \\
\hline & Pulsed jet air, kg/hr & & 0.00 & & 0.00 & & 0.00 & & 0.00 & & 0.00 & & 0.00 & & 0.00 \\
\hline & $\mathrm{CO} 2$ pulse gas, scfm & & 50.0 & & 50.0 & & 50.0 & & 50.0 & & 50.0 & & 50.0 & & 50.0 \\
\hline & $\mathrm{CO} 2$ pulse gas, $\mathrm{kg} / \mathrm{hr}$ & & 156 & & 156 & & 156 & & 156 & & 156 & & 156 & & 156 \\
\hline & Efficiency, $\%$ & & 99.9 & & 99.9 & & 99.9 & & 99.9 & & 99.9 & & 99.9 & & 99.9 \\
\hline & \multicolumn{2}{|l|}{ Baghouse residue, $\mathrm{kg} / \mathrm{hr}$} & 11.2 & & 11.5 & & 8.88 & & 18.4 & & 6.56 & & 110 & & 6.16 \\
\hline & & & & & & & & & & & & & & & \\
\hline
\end{tabular}




\begin{tabular}{|c|c|c|c|c|c|c|c|c|c|c|c|c|c|c|c|}
\hline & \multirow[t]{2}{*}{ Table 1.} & \multicolumn{8}{|c|}{ Estimated offgas composition for the IWTP offgas system. } & \multirow[b]{3}{*}{ Flowrate } & \multirow[b]{2}{*}{$\mathrm{P}$} & \multirow[b]{3}{*}{ Flowrate } & \multirow[b]{2}{*}{$S$} & \multirow[b]{3}{*}{ Flowrate } & \multirow{3}{*}{$\frac{\text { HD1 }}{\text { Comp. }}$} \\
\hline & & G1 & \multirow[b]{2}{*}{ Comp. } & \multirow[b]{2}{*}{ Flowrate } & \multirow{2}{*}{ Mi } & \multirow[b]{2}{*}{ Flowrate } & \multirow{2}{*}{$\begin{array}{l}\text { C5 } \\
\text { Comp. }\end{array}$} & \multicolumn{2}{|c|}{ NOM-60 } & & & & & & \\
\hline & & Flowrate & & & & & & Flowrate & Comp. & & Comp. & & Comp. & & \\
\hline \multicolumn{2}{|c|}{ Parameter } & $\mathrm{kg} / \mathrm{h}$ & (by vol.) & $\mathrm{kg} / \mathrm{h}$ & (by vol.) & $\mathrm{kg} / \mathrm{h}$ & (by vol.) & $\mathrm{kg} / \mathrm{h}$ & (by vol.) & $\mathrm{kg} / \mathrm{h}$ & (by vol.) & $\mathrm{kg} / \mathrm{h}$ & (by vol.) & $\mathrm{kg} / \mathrm{h}$ & (by vol.) \\
\hline \multicolumn{16}{|c|}{ SCRUBBER OUTLET } \\
\hline \multicolumn{16}{|c|}{ Composition } \\
\hline $02, \%$ & & 69.9 & 1.65 & 141 & 1.40 & 86.5 & 0.60 & 107 & 1.36 & 102 & 1.81 & 133 & 0.53 & 69.5 & 1.28 \\
\hline $\mathrm{CO} 2, \%$ & & 3,913 & 67.0 & 9,641 & 69.7 & 14,123 & 71.0 & 7,478 & 69.2 & 5,268 & 67.9 & 24,895 & 71.6 & 5.093 & 68.3 \\
\hline $\mathrm{CO}, \mathrm{ppr}$ & & 0.01 & 2.48 & 0.02 & 2.67 & 0.03 & 2.70 & 0.02 & 2.90 & 0.02 & 3.41 & 0.06 & 2.79 & 0.02 & 3.83 \\
\hline No, $\mathrm{pp}$ & & 0.00 & 0.00 & 0.00 & 0.00 & 0.00 & 0.00 & 0.05 & 6.79 & 0.00 & 0.00 & 0.00 & 0.00 & 0.00 & 0.00 \\
\hline $\mathrm{NO} 2, \mathrm{p}$ & & 0.00 & 0.01 & 0.00 & 0.00 & 0.00 & 0.00 & 0.00 & 0.01 & 0.00 & 0.01 & 0.00 & 0.00 & 0.00 & 0.01 \\
\hline N2, \% & & 157 & 4.21 & 156 & 1.78 & 156 & 1.24 & 158 & 2.29 & 156 & 3.17 & 156 & 0.71 & 156 & 3.30 \\
\hline $\mathrm{SO} 2, \mathrm{pp}$ & & 0.00 & 0.00 & 0.00 & 0.00 & 0.00 & 0.00 & 0.00 & 0.19 & 0.05 & 4.12 & 0.00 & 0.00 & 0.00 & 0.00 \\
\hline $\mathrm{HCl}, \mathrm{pp}$ & & 0.01 & 1.24 & 0.01 & 0.95 & 0.02 & 1.07 & 0.10 & 11.6 & 0.02 & 3.41 & 2.73 & 94.8 & 0.00 & 0.28 \\
\hline $\mathrm{H} 2 \mathrm{O}, \%$ & & 648 & m & 1,535 & x. & 2,206 & 21 & 1,199 & $3 x$ & 861 & 27 & 3,856 & \% & 827 & $2 \%$ \\
\hline THC as & $\mathrm{CH} 2, \mathrm{ppm}$ & 0.00 & 0.25 & 0.00 & 0.27 & 0.00 & 0.27 & 0.00 & 0.29 & 0.00 & 0.34 & 0.00 & 0.28 & 0.00 & 0.38 \\
\hline $\mathrm{Hg}, \mathrm{ppn}$ & & 0.00 & 0.00 & 0.00 & 0.00 & 0.00 & 0.00 & 0.00 & 0.00 & 0.00 & 0.00 & 0.00 & 0.00 & 0.00 & 0.00 \\
\hline & Total & 4,787 & & 11,473 & & 16,572 & & 8,941 & & 6,387 & & 29,043 & & 6,146 & \\
\hline \multicolumn{2}{|c|}{ Flowrate, scfm } & & 1,877 & & 4,447 & & 6,391 & & 3,473 & & 2,494 & & 11,172 & & 2,397 \\
\hline \multicolumn{2}{|c|}{ acfm } & & 2,277 & & 5,395 & & 7.755 & & 4,214 & & 3,026 & & 13,556 & & 2,909 \\
\hline \multicolumn{3}{|c|}{ Offgas molecular weight, wt. basis } & 36.1 & & 36.5 & & 36.7 & & 36.4 & & 36.2 & & 36.8 & & 36.3 \\
\hline \multicolumn{2}{|c|}{ Offgas fowrate, $\mathrm{lb} / \mathrm{hr}$} & & 10,544 & & 25,271 & & 36,502 & & 19,694 & & 14,069 & & 63,972 & & 13,538 \\
\hline \multicolumn{2}{|c|}{ Offgas flowrate, $\mathrm{kg} / \mathrm{hr}$} & & 4,787 & & 11,473 & & 16,572 & & 8,941 & & 6,387 & & 29,043 & & 6,146 \\
\hline Heat capa & ity of offgas, $\mathrm{J} / \mathrm{mol}^{*} \mathrm{C}$ & & 36.6 & & 36.9 & & 37.0 & & 36.8 & & 36.7 & & 37.0 & & 36.7 \\
\hline $\mathrm{H} 2 \mathrm{O}$ cond & ensed from offgas, gpm & & -0.18 & & 0.03 & & 0.16 & & 1.18 & & 2.80 & & -0.30 & & 4.18 \\
\hline $\mathrm{H} 2 \mathrm{O}$ cond & ensed from offgas, $\mathrm{kg} / \mathrm{hr}$ & & -41.97 & & 6.00 & & 37.0 & & 269 & & 635 & & -67.68 & & 950 \\
\hline Makeup y & ater for cooling, $\mathrm{gpm}$ & & 5.37 & & 18.2 & & 27.6 & & 27.5 & & 42.0 & & 41.7 & & 57.4 \\
\hline Makeup V & ater for cooling, $\mathrm{kg} / \mathrm{hr}$ & & 1,219 & & 4,125 & & 6,275 & & 6,239 & & 9,534 & & 9,472 & & 13,048 \\
\hline Residue $\mathrm{H}$ & ater, gpm & & 5.18 & & 18.2 & & 27.8 & & 28.6 & & 44.7 & & 41.4 & & 61.6 \\
\hline Residue n & ater, $\mathrm{kg} / \mathrm{hr}$ & & 1,177 & & 4,131 & & 6,312 & & 6,507 & & 10,168 & & 9,404 & & 13,998 \\
\hline Caustic su & pply, kg/hr & & 0.60 & & 1.09 & & 1.76 & & 11.0 & & 11.5 & & 273 & & 0.17 \\
\hline Scrubber & Liquor Recycle, $\mathrm{kg} / \mathrm{hr}$ & & 11,782 & & 41,331 & & 63,145 & & 65,239 & & 101,829 & & 98,237 & & 139,978 \\
\hline Operating & Conditions & & & & & & & & & & & & & & \\
\hline & Outlet Temperature, F & & 153 & & 153 & & 153 & & 153 & & 153 & & 153 & & 153 \\
\hline & Outlet Temperature, $\mathrm{C}$ & & 67.2 & & 67.2 & & 67.2 & & 67.2 & & 67.2 & & 67.2 & & 67.2 \\
\hline & Static pressure, in. $\mathrm{H} 2 \mathrm{O}$ & & -17.00 & & -17.00 & & -17.00 & & -17.00 & & -17.00 & & -17.00 & & -17.00 \\
\hline
\end{tabular}




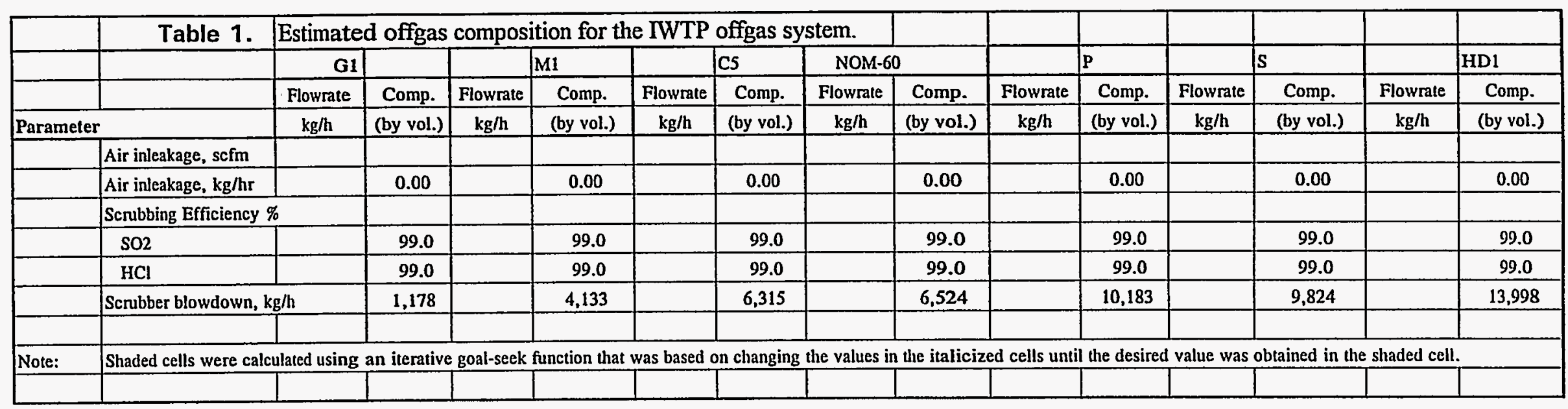




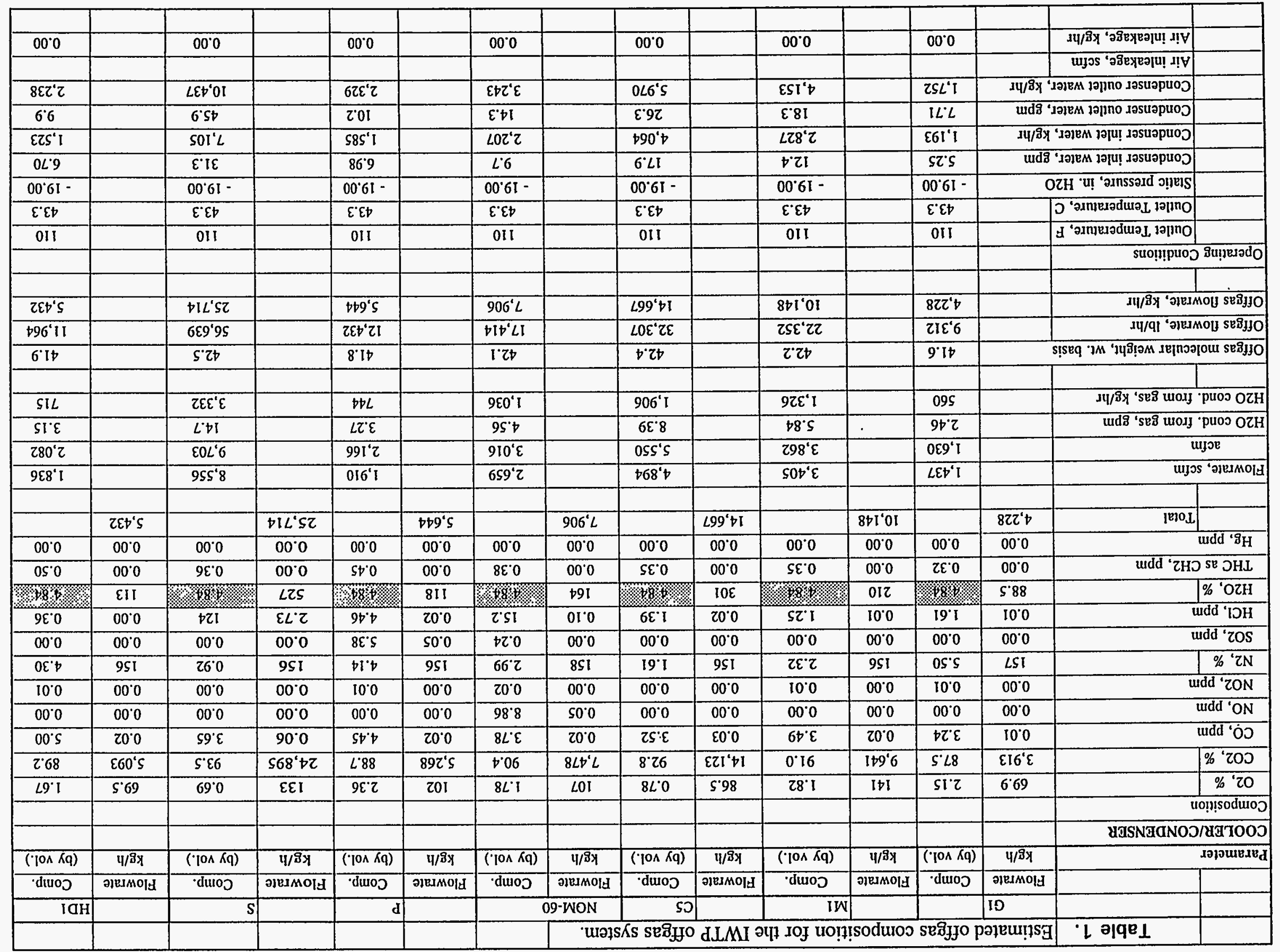




\begin{tabular}{|c|c|c|c|c|c|c|c|c|c|c|c|c|c|c|c|}
\hline & \multirow[t]{3}{*}{ Table 1.} & \multicolumn{7}{|c|}{ Estimated offgas composition for the IWTP offgas system. } & & & \multirow[b]{2}{*}{$P$} & & \multirow[b]{2}{*}{$s$} & & \multirow[b]{2}{*}{ HDI } \\
\hline & & G1 & & & M1 & & C5 & NOM-60 & & & & & & & \\
\hline & & Flowrate & Comp. & Flowrate & Comp. & Flowrate & Comp. & Flowrate & Comp. & Flowrate & Comp. & Flowrate & Comp. & Flowrate & Comp. \\
\hline \multicolumn{2}{|c|}{ Parameter } & $\mathrm{kg} / \mathrm{h}$ & (by vol.) & $\mathrm{kg} / \mathrm{h}$ & (by vol.) & $\mathrm{kg} / \mathrm{h}$ & (by vol.) & $\mathrm{kg} / \mathrm{h}$ & (by vol.) & $\mathrm{kg} / \mathrm{h}$ & (by vol.) & $\mathrm{kg} / \mathrm{h}$ & (by vol.) & $\mathrm{kg} / \mathrm{h}$ & (by vol.) \\
\hline \multirow[t]{2}{*}{ Notes: } & \multicolumn{14}{|c|}{\begin{tabular}{|l|l|l|l|l|} 
1. Assumes cond. $\mathrm{H} 2 \mathrm{O} \mathrm{T}$ of $60 \mathrm{~F}$, and approach $\mathrm{T}$ of $23 \mathrm{~F}$ (water outlet $\mathrm{T}$ of $130 \mathrm{~F}$ when the scrubber outlet gas $\mathrm{T}$ is $153 \mathrm{~F}$ ). & & & \\
\end{tabular}} & \\
\hline & \multicolumn{15}{|c|}{ 2. Shaded cells were calculated using an iterative goal-seek function that was based on changing the values in the italicized cells until the desired value was obtained in the shaded cell. } \\
\hline
\end{tabular}




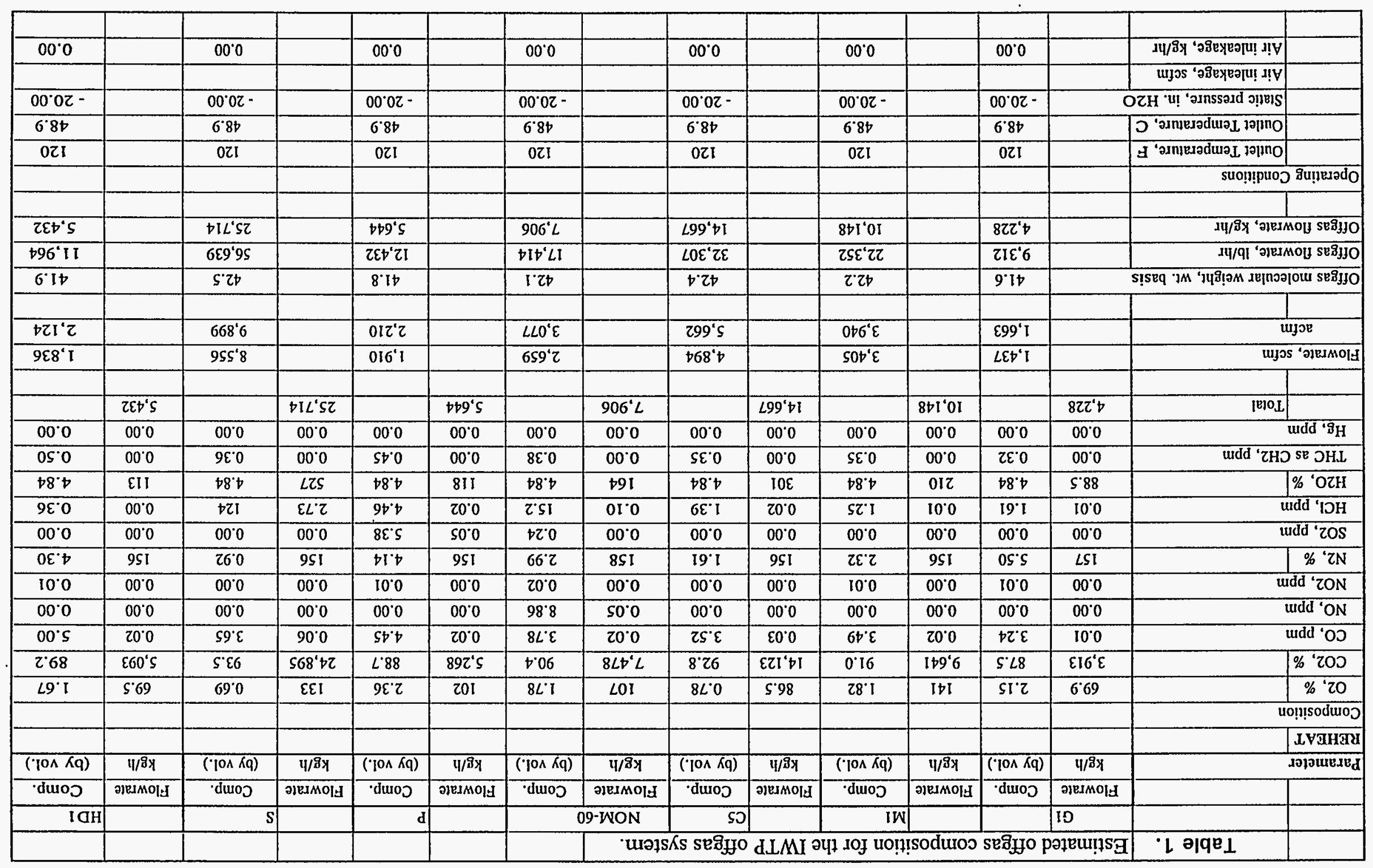




\begin{tabular}{|c|c|c|c|c|c|c|c|c|c|c|c|c|c|c|c|}
\hline & Table 1. & \multicolumn{7}{|c|}{ Estimated offgas composition for the IWTP offgas system. } & & & \multirow[b]{2}{*}{$\mathbf{P}$} & & \multirow[b]{2}{*}{ s } & & \multirow[b]{2}{*}{ HD1 } \\
\hline & & $\mathbf{G 1}$ & & & M1 & & $\mathrm{C5}$ & NOM-6 & & & & & & & \\
\hline & & Flowrate & Comp. & Flowrate & Comp. & Flowrate & Comp. & Flowrate & Comp. & Flowrate & Comp. & Flowrate & Comp. & Flowrate & Comp. \\
\hline \multicolumn{2}{|l|}{ Parameter } & $\mathrm{kg} / \mathrm{h}$ & (by vol.) & $\mathrm{kg} / \mathrm{h}$ & (by vol.) & $\mathrm{kg} / \mathrm{h}$ & (by vol.) & $\mathrm{kg} / \mathrm{h}$ & (by vol.) & $\mathrm{kg} / \mathrm{h}$ & (by vol.) & $\mathrm{kg} / \mathrm{h}$ & (by vol.) & $\mathrm{kg} / \mathrm{h}$ & (by vol.) \\
\hline \multicolumn{16}{|c|}{ CARBON FILTERS } \\
\hline \multicolumn{16}{|c|}{ Composition } \\
\hline $02, \%$ & & 69.9 & 2.15 & 141 & 1.82 & 86.5 & 0.78 & 107 & 1.78 & 102 & 2.36 & 133 & 0.69 & 69.5 & 1.67 \\
\hline $\mathrm{CO} 2, \%$ & & 3,913 & 87.5 & 9,641 & 91.0 & 14,123 & 92.8 & 7,478 & 90.4 & 5,268 & 88.7 & 24,895 & 93.5 & 5,093 & 89.2 \\
\hline $\mathrm{CO}, \mathrm{ppm}$ & & 0.01 & 3.24 & 0.02 & 3.49 & 0.03 & 3.52 & 0.02 & 3.78 & 0.02 & 4.45 & 0.06 & 3.65 & 0.02 & 5.00 \\
\hline No, ppm & & 0.00 & 0.00 & 0.00 & 0.00 & 0.00 & 0.00 & 0.05 & 8.86 & 0.00 & 0.00 & 0.00 & 0.00 & 0.00 & 0.00 \\
\hline NO2, pp & & 0.00 & 0.01 & 0.00 & 0.01 & 0.00 & 0.00 & 0.00 & 0.02 & 0.00 & 0.01 & 0.00 & 0.00 & 0.00 & 0.01 \\
\hline $\mathrm{N} 2, \%$ & & 157 & 5.50 & 156 & 2.32 & 156 & 1.61 & 158 & 2.99 & 156 & 4.14 & 156 & 0.92 & 156 & 4.30 \\
\hline \multicolumn{2}{|c|}{$\mathrm{SO} 2, \mathrm{ppm}$} & 0.00 & 0.00 & 0.00 & 0.00 & 0.00 & 0.00 & 0.00 & 0.24 & 0.05 & 5.38 & 0.00 & 0.00 & 0.00 & 0.00 \\
\hline \multicolumn{2}{|c|}{$\mathrm{HCl}, \mathrm{ppm}$} & 0.01 & 1.61 & 0.01 & 1.25 & 0.02 & 1.39 & 0.10 & 15.2 & 0.02 & 4.46 & 2.73 & 124 & 0.00 & 0.36 \\
\hline $\mathrm{H} 2 \mathrm{O}, \%$ & & 88.5 & 4.84 & 210 & 4.84 & 301 & 4.84 & 164 & 4.84 & 118 & 4.84 & 527 & 4.84 & 113 & 4.84 \\
\hline \multicolumn{2}{|c|}{ THC as $\mathrm{CH} 2, \mathrm{ppm}$} & 0.00 & 0.00 & 0.00 & 0.00 & 0.00 & 0.00 & 0.00 & 0.00 & 0.00 & 0.00 & 0.00 & 0.00 & 0.00 & 0.00 \\
\hline \multicolumn{2}{|l|}{$\mathrm{Hg}$, pṕm } & 0.00 & 0.00 & 0.00 & 0.00 & 0.00 & 0.00 & 0.00 & 0.00 & 0.00 & 0.00 & 0.00 & 0.00 & 0.00 & 0.00 \\
\hline & Total & 4,228 & & 10,148 & & 14,667 & & 7,906 & & 5,644 & & 25,714 & & 5,432 & \\
\hline \multicolumn{2}{|c|}{ Flowrate, scfm } & & 1,437 & & 3,405 & & 4,894 & & 2,659 & & 1,910 & & 8,556 & & 1,836 \\
\hline \multicolumn{2}{|c|}{ acfm } & & 1,581 & & 3,746 & & 5,384 & & 2,925 & & 2,101 & & 9,412 & & 2,019 \\
\hline \multicolumn{3}{|c|}{ Offgas molecular weight, wt. basis } & 41.6 & & 42.2 & & 42.4 & & 42.1 & & 41.8 & & 42.5 & & 41.9 \\
\hline \multicolumn{2}{|c|}{ Offgas flowrate, lb/hr } & & 9,312 & & 22,352 & & 32,307 & & 17,414 & & 12,432 & & 56,639 & & 11,964 \\
\hline \multicolumn{2}{|c|}{ Offgas flowrate, $\mathrm{kg} / \mathrm{hr}$} & & 4,228 & & 10,148 & & 14,667 & & 7,906 & & 5,644 & & 25,714 & & 5,432 \\
\hline \multicolumn{16}{|c|}{ Operating Conditions } \\
\hline & Outlet Temperature, F & & 120 & & 120 & & 120 & & 120 & & 120 & & 120 & & 120 \\
\hline & Outlet Temperature, $\mathrm{C}$ & & 48.9 & & 48.9 & & 48.9 & & 48.9 & & 48.9 & & 48.9 & & 48.9 \\
\hline & Air inleakage, scfm & & & & & & & & & & & & & & \\
\hline & Air inleakage, $\mathrm{kg} / \mathrm{hr}$ & & 0.00 & & 0.00 & & 0.00 & & 0.00 & & 0.00 & & 0.00 & & 0.00 \\
\hline & Hg residue, $\mathrm{g} / \mathrm{hr}$ & & 0.00 & & 0.00 & & 0.00 & & 0.00 & & 0.00 & & 0.00 & & 0.00 \\
\hline & Organic residue, $\mathrm{g} / \mathrm{hr}$ & & 0.00 & & 0.00 & & 0.00 & & 0.00 & & 0.00 & & 0.00 & & 0.00 \\
\hline & Total residue, $\mathrm{g} / \mathrm{hr}$ & & 0.00 & & 0.00 & & 0.00 & & 0.00 & & 0.00 & & 0.00 & & 0.00 \\
\hline & & & & & & & & & & & & & & & \\
\hline
\end{tabular}




\begin{tabular}{|c|c|c|c|c|c|c|c|c|c|c|c|c|c|c|c|}
\hline & & & & & & & & & & & & & & & \\
\hline $69^{\circ} 0$ & & $\tau ? \mathrm{ZI}$ & & $E L^{\prime} 0$ & & $\$ 0^{\circ} z$ & & 660 & & $8 Z^{\prime} I$ & & $\Delta \tau^{\prime} I$ & \multicolumn{2}{|c|}{ 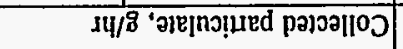 } & \\
\hline \multirow[t]{2}{*}{$00^{\circ} 0$} & & $00^{\circ} 0$ & & $00 \%$ & & 00.0 & & 00.0 & & $00^{\circ} 0$ & & $00^{\circ} 0$ & & 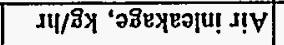 & \\
\hline & & & & & & & & & & & & & & 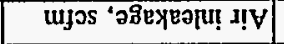 & \\
\hline 6.80 & & 6.87 & & $68 b$ & & 6.87 & & $6.8 t$ & & 6.85 & & $6.8 \mathrm{~b}$ & & 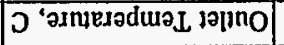 & \\
\hline \multirow[t]{2}{*}{$0 Z \mathrm{I}$} & & $02 \mathrm{I}$ & & OZI & & $0 Z 1$ & & 021 & & $0 Z \mathrm{II}$ & & $0 z \mathbf{z}$ & & 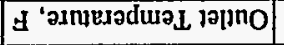 & \\
\hline & & & & & & & & & & & & & & \multicolumn{2}{|c|}{ suou!upuoj sulpedado } \\
\hline & & & & & & & & & & & & & & & \\
\hline ZED'S & & DIL'SZ & & $t+99^{\prime} s$ & & $906^{\circ} \mathrm{L}$ & & $\angle 99^{\prime}+1$ & & $8+1.01$ & & $8 z z^{6} b$ & & \\
\hline $596^{\prime} \mathrm{II}$ & & $6 \varepsilon 9^{\circ} 95$ & & $\tau E \nabla^{*} \tau I$ & & $D I D^{\prime} L I$ & & $\angle O E^{\prime} Z \varepsilon$ & & $2 S \varepsilon^{\prime} Z Z$ & & टाह'6 & & \multicolumn{2}{|c|}{ 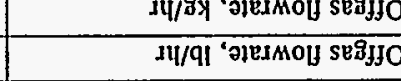 } \\
\hline 6.16 & & $s^{2} z t$ & & $8.1 t$ & & I'zt & & $t \cdot 2 b$ & & 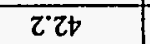 & & $9^{\circ} I \mathrm{Ib}$ & & \multicolumn{2}{|c|}{ 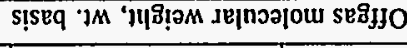 } \\
\hline & & & & & & & & & & & & & & & \\
\hline $610^{\prime} Z$ & & $21 b^{6} 6$ & & $10 r^{\prime} \mathrm{Z}$ & & $526^{\circ} \mathrm{Z}$ & & $t 8 \varepsilon^{\prime} S$ & & $9 t L^{\prime} E$ & & $18 S^{\prime} \mathrm{T}$ & & \multicolumn{2}{|c|}{ uyx } \\
\hline \multirow[t]{3}{*}{$9 E 8^{1} I$} & & $9 \varsigma \varsigma^{\prime} 8$ & & $016^{\prime} \mathrm{I}$ & & $6 \varsigma 9^{\circ} \mathrm{Z}$ & & $768^{\prime} \mathrm{b}$ & & $\operatorname{sot}^{\circ} \varepsilon$ & & LEt'T & & \multicolumn{2}{|c|}{ 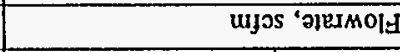 } \\
\hline & & & & & & & & & & & & & & & \\
\hline & $2 E t^{\prime} s$ & & $\nabla I L ' s z$ & & $t p 9$ 's & & $906^{\circ} \mathrm{L}$ & & $\angle 99^{\prime} \mathrm{bl}$ & & $80 I^{\prime} 01$ & & $8 z z^{\prime} b$ & | 1810L & \\
\hline $00 \%$ & $00^{\circ} 0$ & $00 \%$ & $00^{\circ} 0$ & $00 \%$ & $00^{\circ} 0$ & $00 \%$ & $00^{\circ} 0$ & $00^{\circ} 0$ & $00^{\circ} 0$ & $00^{\circ} 0$ & $00^{\circ} 0$ & $00^{\circ} 0$ & $00^{\circ} 0$ & \multicolumn{2}{|r|}{ urdd '9 $9_{\mathrm{H}}$} \\
\hline $00^{\circ} 0$ & $00^{\circ} 0$ & 00.0 & 000 & $00 \%$ & $00^{\circ} 0$ & 00.0 & $00^{\circ} 0$ & $00^{\circ} 0$ & $00 \%$ & $00^{\circ} 0$ & $00^{\circ} 0$ & $00 \%$ & $00^{\circ} 0$ & \multicolumn{2}{|c|}{ urdd 'حHO Se כHL } \\
\hline $88^{\circ} \mathrm{b}$ & EII & 68.6 & $\angle Z S$ & 78.7 & 811 & $78^{\circ} t$ & 791 & $78^{\circ} 6$ & $10 \varepsilon$ & 58.6 & 012 & 78.6 & $\$ .88$ & \multicolumn{2}{|r|}{$\%{ }^{\prime} \mathrm{OZH}$} \\
\hline $9 \varepsilon^{\prime} 0$ & 000 & $\mathrm{DZI}$ & $\varepsilon L^{\prime} Z$ & $9 \boldsymbol{b}^{\circ} \boldsymbol{b}$ & $20^{\circ} 0$ & $\tau$ 'SI & 010 & $6 E^{\top} I$ & 20.0 & SI'I & $10 \%$ & 19.1 & $10^{\circ} 0$ & \multicolumn{2}{|r|}{ ưdd' 'IOH } \\
\hline $00^{\circ} 0$ & 000 & $00^{\circ} 0$ & $00^{\circ} 0$ & $8 \varepsilon^{\circ} \mathrm{S}$ & $50^{\circ} 0$ & $\Delta z^{\prime} 0$ & $00^{\circ} 0$ & $00^{\circ} 0$ & $00 \%$ & $00^{\circ} 0$ & $00^{\circ} 0$ & $00^{\circ} 0$ & $00^{\circ} 0$ & \multicolumn{2}{|r|}{ tudd 'zos } \\
\hline $0 \varepsilon^{\prime} b$ & $9 S I$ & 26.0 & 9SI & $t I^{\circ} t$ & $9 S \mathrm{I}$ & $66^{\circ} \mathrm{Z}$ & $8 \mathrm{SI}$ & 19.1 & $9 S I$ & $z \varepsilon^{\prime} z$ & $9 S I$ & $0 S^{\circ} S$ & $L S I$ & \multirow{2}{*}{\multicolumn{2}{|c|}{$\frac{1 \% \text { ' } \mathrm{N}}{\text { uddd 'ZON }}$}} \\
\hline $10 \%$ & 00.0 & $00^{\circ} 0$ & $00^{\circ} 0$ & $10 \%$ & $00^{\circ} 0$ & $20^{\circ} 0$ & $00^{\circ} 0$ & $00^{\circ} 0$ & $00^{\circ} 0$ & $10 \%$ & 00.0 & $10 \%$ & $00^{\circ} 0$ & & \\
\hline $00^{\circ} 0$ & 00.0 & $00^{\prime} 0$ & $00^{\circ} 0$ & $00^{\circ} 0$ & $00^{\circ} 0$ & 98.8 & $50^{\circ} 0$ & $00 \%$ & $00^{\circ} 0$ & 00.0 & $00^{\circ} 0$ & $00^{\circ} 0$ & $00^{\circ} 0$ & \multicolumn{2}{|r|}{ udd 'ON } \\
\hline $00^{\circ} \mathrm{s}$ & $20^{\circ} 0$ & $59^{\circ} \varepsilon$ & $90^{\circ} 0$ & $\mathcal{S} \boldsymbol{D}^{t} \boldsymbol{t}$ & $20^{\circ} 0$ & $8 L^{\circ} \mathcal{E}$ & $20^{\circ} 0$ & $\tau S^{\prime} \mathcal{E}$ & $\varepsilon 0^{\circ} 0$ & $60^{\circ} \varepsilon$ & $20^{\circ} 0$ & $\boldsymbol{t} \tau^{*} \mathcal{E}$ & $10^{\circ} 0$ & \multicolumn{2}{|r|}{ undd 'os } \\
\hline 2.68 & $E 60^{\circ} S$ & $s^{\prime} \varepsilon 6$ & $S 68^{\prime} \triangleright 2$ & $\angle ' 88$ & $89 z^{\prime} \mathrm{s}$ & 606 & $8 \angle t^{\circ} L$ & 8.26 & $\operatorname{cZI}^{\prime} \triangleright I$ & 0.16 & $179^{\prime} 6$ & $5: \angle 8$ & $\varepsilon I \sigma^{\prime} \varepsilon$ & \multicolumn{2}{|r|}{$\%$ '200 } \\
\hline \multirow[t]{3}{*}{$\angle 9^{\prime} I$} & 5.69 & 690 & EEI & $9 \varepsilon^{2} Z$ & 201 & $8 L^{\prime} I$ & $\angle 01$ & $8 L^{\circ} 0$ & $5 ' 98$ & $28^{\prime} \mathrm{I}$ & $i b I$ & SI'Z & 6.69 & \multirow{2}{*}{\multicolumn{2}{|c|}{$\frac{1 \% 20}{\text { uo!̣!!soduroj }}$}} \\
\hline & & & & & & & & & & & & & & & \\
\hline & & & & & & & & & & & & & & \multicolumn{2}{|c|}{ 女GLTIU Yd3H } \\
\hline$(10 \wedge K q)$ & $4 / 3 x$ & $(\cdot 10 \wedge K q)$ & $4 / 8 x$ & $(10 \wedge K q)$ & $4 / 8 x$ & $(\bar{c}) \mathrm{Kq})$ & प//8Y & $(\cdot 10 \wedge K q)$ & $4 / 8 y$ & $\left({ }^{\prime} 10 \wedge \mathrm{Kq}\right)$ & प//87 & $(' 10 \wedge \mathrm{Kq})$ & $4 / 8 x$ & \multicolumn{2}{|r|}{ 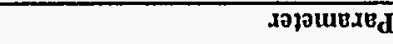 } \\
\hline dwoo & ग1ESMOII & duloo & गएल & duos & गJEมMO|A & duod & ग1एسMO|A & duroj & \begin{tabular}{|l|} 
ग1य \\
\end{tabular} & deuos & गएस & - duoD & ग1ЕMO|A & & \\
\hline \multirow[t]{2}{*}{ IaH } & & $s$ & & d & & \multirow{2}{*}{\multicolumn{8}{|c|}{ 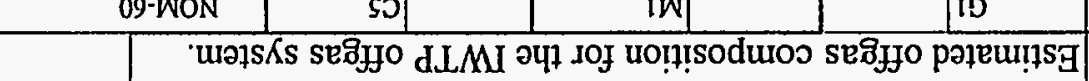 }} & & \\
\hline & & & & & & & & & & & & & & $\iota^{\prime}$ өlqe $\perp$ & \\
\hline
\end{tabular}




\begin{tabular}{|c|c|c|c|c|c|c|c|c|c|c|c|c|c|c|c|}
\hline & \multirow[t]{2}{*}{ Table 1.} & \multicolumn{8}{|c|}{ Estimated offgas composition for the IWTP offgas system. } & & \multirow[b]{2}{*}{ P } & & \multirow[b]{2}{*}{$s$} & & \multirow[b]{2}{*}{ HDI } \\
\hline & & G1 & & & $\mathrm{Ml}$ & & $\mathrm{C5}$ & NOM-6 & & & & & & & \\
\hline & & Flowrate & Comp. & Flowrate & Comp. & Flowrate & Comp. & Flowrate & Comp. & Flowrate & Comp. & Flowrate & Comp. & Flowrate & Comp. \\
\hline \multicolumn{2}{|l|}{ Parameter } & $\mathrm{kg} / \mathrm{h}$ & (by vol.) & $\mathrm{kg} / \mathrm{h}$ & (by vol.) & $\mathrm{kg} / \mathrm{h}$ & (by vol.) & $\mathrm{kg} / \mathrm{h}$ & (by vol.) & $\mathrm{kg} / \mathrm{h}$ & (by vol.) & $\mathrm{kg} / \mathrm{h}$ & (by vol.) & $\mathrm{kg} / \mathrm{h}$ & (by vol.) \\
\hline \multicolumn{16}{|c|}{ INDUCED DRAFT FAN } \\
\hline \multicolumn{16}{|c|}{ Composition } \\
\hline $02, \%$ & & 69.9 & 2.15 & 141 & 1.82 & 86.5 & 0.78 & 107 & 1.78 & 102 & 2.36 & 133 & 0.69 & 69.5 & 1.67 \\
\hline $\mathrm{CO} 2, \%$ & & 3,913 & 87.5 & 9,641 & 91.0 & 14,123 & 92.8 & 7,478 & 90.4 & 5,268 & 88.7 & 24,895 & 93.5 & 5,093 & 89.2 \\
\hline \multicolumn{2}{|l|}{$\mathrm{CO}, \mathrm{ppm}$} & 0.01 & 3.24 & 0.02 & 3.49 & 0.03 & 3.52 & 0.02 & 3.78 & 0.02 & 4.45 & 0.06 & 3.65 & 0.02 & 5.00 \\
\hline \multicolumn{2}{|l|}{ NO, ppm } & 0.00 & 0.00 & 0.00 & 0.00 & 0.00 & 0.00 & 0.05 & 8.86 & 0.00 & 0.00 & 0.00 & 0.00 & 0.00 & 0.00 \\
\hline \multicolumn{2}{|c|}{ NO2, ppm } & 0.00 & 0.01 & 0.00 & 0.01 & 0.00 & 0.00 & 0.00 & 0.02 & 0.00 & 0.01 & 0.00 & 0.00 & 0.00 & 0.01 \\
\hline $\mathrm{N} 2, \%$ & & 157 & 5.50 & 156 & 2.32 & 156 & 1.61 & 158 & 2.99 & 156 & 4.14 & 156 & 0.92 & 156 & 4.30 \\
\hline \multicolumn{2}{|c|}{$\mathrm{SO} 2, \mathrm{ppm}$} & 0.00 & 0.00 & 0.00 & 0.00 & 0.00 & 0.00 & 0.00 & 0.24 & 0.05 & 5.38 & 0.00 & 0.00 & 0.00 & 0.00 \\
\hline \multicolumn{2}{|c|}{$\mathrm{HCl}, \mathrm{ppm}$} & 0.01 & 1.61 & 0.01 & 1.25 & 0.02 & 1.39 & 0.10 & 15.2 & 0.02 & 4.46 & 2.73 & 124 & 0.00 & 0.36 \\
\hline $\mathrm{H} 2 \mathrm{O}, \%$ & & 88.5 & 4.84 & 210 & 4.84 & 301 & 4.84 & 164 & 4.84 & 118 & 4.84 & 527 & 4.84 & 113 & 4.84 \\
\hline \multicolumn{2}{|c|}{ THC as CH2, ppm } & 0.00 & 0.00 & 0.00 & 0.00 & 0.00 & 0.00 & 0.00 & 0.00 & 0.00 & 0.00 & 0.00 & 0.00 & 0.00 & 0.00 \\
\hline \multicolumn{2}{|l|}{$\mathrm{Hg}, \mathrm{ppm}$} & 0.00 & 0.00 & 0.00 & 0.00 & 0.00 & 0.00 & 0.00 & 0.00 & 0.00 & 0.00 & 0.00 & 0.00 & 0.00 & 0.00 \\
\hline & Total & 4,228 & & 10,148 & & 14,667 & & 7,906 & & 5,644 & & 25,714 & & 5,432 & \\
\hline \multicolumn{2}{|c|}{ Flowrate, scfm } & & 1,437 & & 3,405 & & 4,894 & & 2,659 & & 1,910 & & 8,556 & & 1,836 \\
\hline \multicolumn{2}{|c|}{ acfm } & & 1,581 & & 3,746 & & 5,384 & & 2,925 & & 2,101 & & 9,412 & & 2,019 \\
\hline \multicolumn{3}{|c|}{ Offgas molecular weight, wt. basis } & 41.6 & & 42.2 & & 42.4 & & 42.1 & & 41.8 & & 42.5 & & 41.9 \\
\hline \multicolumn{2}{|c|}{ Offgas flowrate, $\mathrm{lb} / \mathrm{hr}$} & & 9,312 & & 22,352 & & 32,307 & & 17,414 & & 12,432 & & 56,639 & & 11,964 \\
\hline \multicolumn{2}{|c|}{ Offgas flowrate, $\mathrm{kg} / \mathrm{hr}$} & & 4,228 & & 10,148 & & 14,667 & & 7,906 & & 5,644 & & 25,714 & & 5,432 \\
\hline \multicolumn{16}{|c|}{ Operating Conditions } \\
\hline & Outlet Temperature, F & & 120 & & 120 & & 120 & & 120 & & 120 & & 120 & & 120 \\
\hline & Outlet Temperature, $\mathrm{C}$ & & 48.9 & & 48.9 & & 48.9 & & 48.9 & & 48.9 & & 48.9 & & 48.9 \\
\hline & Air inleakage, scfm & & & & & & & & & & & & & & \\
\hline & Air inleakage, $\mathrm{kg} / \mathrm{hr}$ & & 0.00 & & 0.00 & & 0.00 & & 0.00 & & 0.00 & & 0.00 & & 0.00 \\
\hline & & & & & & & & & & & & & & & \\
\hline
\end{tabular}

